\title{
De patient en zijn naasten : de invloed van houdingen in het persoonlijk netwerk van de patient op zijn medische consumptie
}

Citation for published version (APA):

Mootz, M. (1981). De patient en zijn naasten : de invloed van houdingen in het persoonlijk netwerk van de patient op zijn medische consumptie. [Doctoral Thesis, Maastricht University]. Rijksuniversiteit Limburg. https://doi.org/10.26481/dis.19810702mm

Document status and date:

Published: 01/01/1981

DOI:

10.26481/dis. $19810702 \mathrm{~mm}$

Document Version:

Publisher's PDF, also known as Version of record

Please check the document version of this publication:

- A submitted manuscript is the version of the article upon submission and before peer-review. There can be important differences between the submitted version and the official published version of record.

People interested in the research are advised to contact the author for the final version of the publication, or visit the DOI to the publisher's website.

- The final author version and the galley proof are versions of the publication after peer review.

- The final published version features the final layout of the paper including the volume, issue and page numbers.

Link to publication

\footnotetext{
General rights rights.

- You may freely distribute the URL identifying the publication in the public portal. please follow below link for the End User Agreement:

www.umlib.nl/taverne-license

Take down policy

If you believe that this document breaches copyright please contact us at:

repository@maastrichtuniversity.nl

providing details and we will investigate your claim.
}

Copyright and moral rights for the publications made accessible in the public portal are retained by the authors and/or other copyright owners and it is a condition of accessing publications that users recognise and abide by the legal requirements associated with these

- Users may download and print one copy of any publication from the public portal for the purpose of private study or research.

- You may not further distribute the material or use it for any profit-making activity or commercial gain

If the publication is distributed under the terms of Article $25 \mathrm{fa}$ of the Dutch Copyright Act, indicated by the "Taverne" license above, 
DE PATIENT EN IINN NAASTEN 


\title{
DE PATIENT EN ZIJN NAASTEN
}

\section{De invloed van houdingen in het persoonlijk netwerk van de patiënt op zijn medische consumptie}

\begin{abstract}
PROEFSCHRIFT
TER VERRRIJGING VAN DE GRAAD VAN DOCTOR IN DE SOCIALE WETENSCHAPPEN

AAN DE RUKSUNTWERSITEIT LIMBURG, OP GEZAG VAN DE RECTOR MAGNIFICUS DR. W.H.F.W. WIJNEN, HOOGLERAAR IN DE FACULTEIT DER GENEESKUNDE, VOLGENS BESLUIT VAN HET COLLEGE VAN DEKANEN IN HET OPGENBAAR TE VERDEDIGEN OP DONDERDAG 2 JULI 1981, DES NAMIDDAGS OM 16.00 UUR PRECIES, IN DE AULA DER UNIVERSITEIT
\end{abstract}

DOOR

MARIJKE MOOTZ

GEBOREN TE EINDHOVEN IN 1946

DRUKKERIJ J.H. PASMANS B.V., "S-GRAVENHAGE 


\author{
Promotor: Prof. Dr. H. Philipsen \\ Referenteri: prof. Dr. W. Browwer \\ Prof. Dr. W.J.A. van den Heuvel
}

Het onderzoek werd mogelijk gemakt door het sociaal en Culturee 1 Planbureau 



$$
\text { . }
$$




\section{INHOUDSOPGAVE}

VOORTOORD

DEEL I VAN PROBZERWSTELIINE NAAR ONDERZOEK

Hoofastuk i Inleiding 1

1.1. wamom deze studie? II

1.2. Probleemste11ing: ean owerzicht. I3

1.3. De indeling van het boek. 14

Foofdstuk 2 probleemstiling fin literaturoverzicht 17

2.1. Inleiding 17)

2.2. Vershillende modellen ter verklaring van medische consumple 19

2.3. Conclusies: empirische menthodsche anachtspunter 26

2. A. Probleensteling en ondexzoekbaarheia 32

Hoordstuk 3 Onderzoekbarhetd en herformuering 37

3.1. De ziektebelden in dit onderzoek 37

3.2. Gevolgen van de gekozen onderzoeksopzet roox de oorspronkelijke 45

3.3. Hypothesen

Hoofdstuk 4 onderzolksopzet en -uitvoering 57

4.1. Inleiding 57

4.2. De te ondervigen persionen 57

4.3. Het lekennetwerk 66

4.4. Het professionele systeem 68

4.5. Onderzoeksworbereliang 70

Hoofastuk 5 Samervatting 73

DEEL IT DE GENEIGDEEID TOM HET GEBROLK VAN MEDISCHE VOORZIENTWGEN

Hacfastuk 6 Consumptiegeneigdheid nadar bezien 79

6. Inlieiding 79

6.2. Het attithdebegrip 79

6. 3. Operationaliseringen van het attitudebegrip 82

6.4. Consumptiegene igdheda in dit onderzolk 95

Hoofdstuk 7 consurptiegeneigdheld in enkele samenthengen 99

7.1. Inleting 99

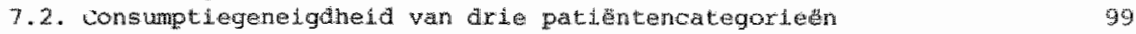

7.3. Consumptegeneigdhetd en medische consumptie: een ererste
verkening

7.4. Consumptiegeneigahaid en persoonskermerkeri 112

7.5. Medische kemis. stress en consumptegeneigdheid 11.4

Hootastuk $B$ Samenvatting 123 
DEEL III HET LEXENSYSTEEM

Hoofdstuk 9 geachityring wan het lekensysteem 129

9. 1. Inletding 129

9.2. De cariang vark her lekenrwatwerk 129

9.3. De meest betwokken lekenawiseurs: wie zijn dat? 133

9. 4. De omvang vari het partiele netwexk en de consumptiegeneiga$\begin{array}{ll}\text { heid van de patienten } & 136\end{array}$

Hoodstuk 10 De consumptiegrneigaheid in lekmetwerken 139

10.1. Operatonal1:saringen 139

10.2. Lekenatwiseurs van de drie patientencategorieun
en hun consumptiegenelgaheid.

10.3. Consumptieganelgaheld wam patienten en hun lekenadviseurs 144

10.4. Homogene en hetrogene retwerken 148

Hopdstuk 11 Functies van netwerkleden, consumptiegenigdheld en medische consumptie

11.1. rndeiding

11.2. Instrumentele functies van lekenadwiseurs: praktische hulp in wroband met de andoening

11.3. Expressleve Eumeties van leknadvi seurs: emationele steun bil de andoening

156

11.4. Consumptiegenejgaheid wan lekenadvisurs en thedische consurptic wan patidntwespondenten

160

1.1.5. Tot bes 1uit:

164

Hofdstuk. 12 Samenvatting 167

DEEL IV HET PROEESSIONELE SYSTEEW

Hoofdstuk 13 Verschillen cussen huisarts- en specialistpatienten 173

13.1. Inleelding $\quad 173$

13.2. Kenmerken van de aandoeningen 173

13.3. Kenmerken van de patient 176

13.4. Consumptiegeneigdheid van specialist- en huisartspatienten 177

13.5. Medische consumptie, consumptiegerneigdheid en het leken-
netwerk van buisarts en specialistpatienten

$\begin{array}{lr}\text { 13.6. Tot besluit } & 192\end{array}$

Hootdotuk 14 congumptegenel guheid en overige wormen van
medische comsumptie

14.1. Wet gebulk van werschillende gezondheidszorgvooxzieningen 195

14.2. Met radplegen van aldermatieve genemers 199

14.3. Consumpti.egraightheid en verzekeringsworm 203

Hoofdatuk 15 Samenvatting 211 
DERL V SWNOPSIS

Hoofdstuk 16 overziont 217

16.1. Inleiding 21 ?

16.2. De consumptegenelgdheid van de patisnt 217

16.3. De invloed van het lekennetwerk 220

16.4. ret professionele systeen 222

Hoofdstuk 17 slotbeschouwingen 225

17.1. Onderzoeksyagen opndeuw bezien 225

17.2. Thearetisiche betekenis 227

117.3. Methodische betekenis 229

17.4. Matschappe1.jke betekenis 230

\begin{tabular}{lr} 
SUMMARY & 233 \\
\hline
\end{tabular}

\begin{tabular}{lr} 
LITERATUUR. & 239 \\
\hline
\end{tabular}

\section{BIJ LAGEN}

1. Patientencategorieen en persoonskenmerken 253

2. Opvattinger over medische zorg en over ziekte 254

3. Attituden ten aanien van de elgen arts 257

4. Variabelen ter bepaling van de "ziektebeleving" 259

5. Factoranalyse gedragsintentie 262

6. Samenhangen tussen het aantal huisartscontacten en comsumptie-

7. Matrix van product-moment correlatiecoefficienten 26 唵

8. Matrix van product-moment correlatiecoefficienten tussen huismits-
contacten in verbard met de aandoening en consumptiegeneigdheid 266

9. Operationaliseringen van medische kennis en stress 267

10. Attituden war lekenadwseuxs ten aanzien van de aandoening war
de patient

11. Bepaling van homogene en heterogene netwerken, achtergronden van praktische bulp en enotionele steun in netwerken 271

12. Dinensies in de attitude ten aanzien van de eigen arts 275

13. Controlenoodzaak en medische consumptie 276

14. Matri $x$ van product-moment correlatwecoëficienten apart voor huisarts - en specialistpatiënter 277

15. Variabelen met betrekking tot overige vormen van mecische wonsumptie 278

16. Artsenenquete 279

\begin{tabular}{ll} 
CURRECUILM VITAE & 290 \\
\hline
\end{tabular} 
VOORWOORD

Het materiaal voor deze studie werd mij ter beschikking gesteld door het Saciaal en Cultureel plambureau. Het bureau financierde het veldwexk en stelde mij in de gelegenheid, de gegevens met behulp van de computer te bewerken. op deze platus wil ik hiervoor mijn erkentelijkheid tonen.

Verschillende personen hebben aan het ontstan van dit boek bijgedragen. In de eerste plats will ik alle respondenten en hun "netwerkleden" danken voor hun bereidheid on an het onderzok mee te wexken. De resultaten zullen hen nar all le warschijnlijkheid teleur stellen, omdat de ervaringen van individuele patienten en hun adviseurs daarin niet tot ultakuking konden komen. Op att punt hoop ik op begrlp. ook dank ik de artsen van de patiënt-respondenten voor het vertrouwen dat $z i j$ in mij stelden, doox de voor het onderzoek wardevolie infomatie te verstrekken.

Mijn dank gaat verder uit naar mijn promotor, prof. dr. H. Philipsen, die op de hem eigen wijze op essentiele momenten sturend is opgetreder. Hij heeft daamee een heilvolle invloed gehad op de grote lijn van onderzoek en rapportage. Voorts nam mw. prof. dx. M.J. Drop; zij heeft alle concept-teksten diepgaand bestudeerd. Har vele waardevolle suggesties heb $1 k$ dankbaar verwerkt. In de laatste fase van het werk hebben tenslotte mijn referenten, prof. dr. W. Brouwer en prof. dx. W.J.A. van den Heuvel belangrijke opmerkingen bij het eindconcept geplaatst, die nog op het laatst in de eindtekst konden worden opgeromen.

Mijn collega's mw. dxs. M. Konings-van der smoek en ax. A. F. N. Nauta ben ik bijzonder erkentelijk voor de wjye warop zij mij gedurende de afgelopen jaren blj het vervatalgen van het werk hebben bijgestaan. Hun adviezen en seun zijn voor mij van groot belang geweest. Voorts wil ik dhr. D. Niggebrugge, programeur bij het social en cultureel plambureau danken; hij heeft het onderzoeksmaterial toegankelijk gemakt woor de ana1yse. Woor de begelelding van het veldwerk en de eerste bewerkingen van het grondmatexiaal ben $i k$ in het bijzondex mw. H.M.S.A. van Kuppesveld-Langhout, medewerkster bij het Inst1- 
tuut voor roegepaste Soctologie in Nijmegen, erkentelijk.

Alg soclologe begaf ik mij voor bepalde onderdelen van de studie op medisch terrein. Dhr. J.E. Boumeester, rustend hulsarts te den Haag, mw. J.J.C. Meursing-Droog, huisarts te Delft en Dr. A.P. Oliemans, huisarts te den Haag, hebben mij hierbij begeleda.

Bij de studie naar kenmerken van de drie bij het onderzoek betrokken patientencategorieën ben ik door verschillende personen geadviseerd. Mijn dank gaat uit naar drs. J.P.M. Diederiks van de Rijksuniversiteit Limburg en B.T.J. Meursing, cardioloog 1.0. te Delft met betrekking tot hartinfarctpatiënten; naar mw. J.E.W. Bronkhorst-Thijsse, radslid DVN en drs. F.G.E. Van der Horst vari de Rijksuniversiteit Limburg met betrekking tot suikerpatiënten; en naar mw. dr. M.A. BremerSchulte van de Rijksuniversiteit Limburg en mw. drs. M. van Veen-Viëtor, oud-bestuurslid NBPV met betrekking tot psoriasispatiënter.

Tens lotte ben lk mw. G.E. Hamelink-Guttenberg zeer exkentelijik voor de wijze warop zij de concept-tekst in zo korte $t i j d$ gexeed heeft gemakt voor druk. 
D E E I I

$V A N$ P R O B L EEMSTELI ING

N A A R ON DERZOEK 
Hoofdstuk 1: Inlelaing

1.1. Waarom deze studie?

Waarom gaan sommige mensen met bepalde klachten wa 1 en anderen met vergelijkbare klachten niet nar de dokter?

Deze vraag houdt vele onderzoekers bezig. Zil worat niet alleen door medisch sociologen gesteld, mar ook door psychologen (Van der Ploeg, 1980), economen en econometristen (Van der Gaag, 1978, Rutten, 1979), wiskundigen (Van de Ven en Van Wi.tet, 1980 ) en natuur $1 j j k$ door artsen (Neven, 1980) 1). Het oogmerk waarmee de vraag wordt gesteld - en daarmee de wijze warop men probeert een antwoord te vinden - verschilt wel, maar het kernprobleem blijft het verschil in medische consumptie tussen mensen.

In Nederland heeft onder meer Cassee (1973) op dit gebled belangrijk werk verricht. Vele onderzoekers hebben hun ultgangspunten en veronderstelingen aan zijn studie ontleend. ook het hier beschreven onderzoek vindt darin zijn vertrekpunt. Het gaat uit van de door Cassee (en vorr hen 0.a. door Andersen, 1968, In de Verenigde Staten) onderscheiden determinanten van medische consumptie.

Het raadplegen van de dakter wordt volgens zijn model door vier complexe zaken beinvioed. Het wordt beinvloed door (1) bepalde kenmerken van de persoon, door (2) ziekteverschijnselen, door (3) beschikbare tija of geld voor het doktersconsult of voor de gevolgen ervan alsmede door (4) de geneigdheld tot het inroepen van medische hulp. Dat latste punt - de geneigdheid tot medische consumptie - stat in deze studie centraal.

cassee definleert consumptiegeneigdheid als "het complex van houdingen, dat een individu in meerdere of mindere mate voorbeschikt tot medische consumptie" (Cassee, 1973, p. 46). Het. is een moilijk te preciseren begrip, dat door zijn vaagheid niet makkelijk te onderzoeken is. In de rij van deteminanten van mealsche consumptie speelt, consumptlegeneigaheid bovendien een vilj ondergeschikte rol* lemands zlekteverschijnselen (zijn consumptienoodzak) en iemands leefijed en opleiding zijn daarbij veel belangrijker. Dat geldt vooral in een land als Nederland, waar de financiële gevolgen van een doktersbezoek voor de patient 
ten gevolge van verschlllende verzekeringsvomen gexing zijn.

De reden warom wij de consumptiegenelgdheid desondanks wilen bestuderen lat zich in twee punten samenvatten. In de eerste plaats is dit complex van houdingen een mogelijk aangrijpdngspunt an lemands medische consumptie te beinvloeden. Het gat hierbij or het verschil tussen krachtige variabelen, die veel verklaren dan de ene kant en manipuleerbare variabelen, warmee men mogelijk lets kan veranderen an de andere kant. (Ellemers, 1976.) Persoonskenmerken en ziekteverschijnselen moeten meestal als gegeven worden beschouwd. Als "krachtige variabelen" belnvloeden zij de medische consumptte heel duidelijk, maar zij zijh moeilijk te beinvioeden.

Iemands houding ten aanzien van ziekte en gezondheld en ten aanzien van de medische zorg kan men echter tot op zekere hoogte wel veranderen. De gezondheidsvoorlichting en -opvoeding richt zich (naast hax preventieve taak) bijvoorbeeld daarop. zij probeert de kennis van medische zaken bij de bevolking te vergroten, zodat ziektesymptomen juist kunnen worden geinterpreteerd. zij geeft voorlichting over bepalde behandelingswijzen en -mogelijkheden, wartegen men zijn beslising om medische hulp in te roepen, kan afwegen. Als er in de gezondheidszorg sprake is van een noodzakelijke mentaliteitswexandering van potentiële patienten of van de noodzaak, om patiënten mondig te maken, dan heeft men het in felte over hun consumptiegeneigdheid. Hiermee wil ovexigens niet gezegd $z i j n$, dat beInvloeding van consumptiegeneigdheld een eenvoudige zaak zou zijn. Als men echter iemands medische consuraptie wil sturen, zal - afgezien van het voorkomen van ziekte - de genelgaheid tot die consumptie toch het belangrijkste handvat moeten zijn.

De tweede reden voor onze belangsteliling in dit onderwerp 1s misschien belangrijker. zij heeft te maken met het feit, dat de begrippen gezondheld en ziteke in westerse landen in toenemende mate voor interpretratie vatbaar zijn. Naast objectieve en acute syndromen kan men immers subjectleve ziekteverschijnselen onderschelden (Hogerzeil, 1966) warbij de subjectieve klachten van de patient, zijn zlektegevoel centraal staar. Bij dit soort klachten heeft de patidnt een redelijk grote mate van vrijheid om te beslissen of hij zichzelf wel of niet ziek acht (Philipsen. 
1969a, Gel, $1976 \%$. In studies over het iekteverzuim en de verzekeringsgeneeskunde kont naar voren, dat de omvang van deze "grijze ziekten" toeneent Wan der waas, 1975, Whilipsen, 1977.. Daarmee neemt niet alleen de vrijheld toe, om zich wel of riet ziek te melden, maar ook de vritheid m medische hulp in te roepen. Men mag veronderstellen, dat het belang van de geneigdheid tot het raadplegen wan de arts - vergeleken met het belang vam de consumptienoodzak en wan personskenmerken daarmee eveneens relatief toe zal nemen.

\subsection{Probleemstelling: een overzicht}

Tot zover onze voomaamste overwegingen, om de consumptiegenelgdheid nader te bestuderen. Wat willen wij daarvan nu precies weten?

onze probleemstelling valt in wier delen uiteen. In de eerste plaats moeten wij ons bezinnen op de wijze warap consumptiegeneigdheid onderzocht kan worden en hoe wij het begrip operationaliseren. Daarbij vragen wij ors af, in welke mate het hebben van een bepalde aandoening de consumptiegeneigdheld beinvloedt. Deze vraag is vari belang, omdat uit onderzoek telkens weer blijkt, dat de ard van de aandoening, warover men de arts raadpleegt, de mealsche consumptie sterk bepalt. Of en op welke wijze de aard van de aandoening de consumptiegeneigaheld bepaalt is minder vaak onderwerp van studie geweest.

In het tweede deel van de proble emstelling komt de vraag aan de orde, in welke mate de consumptiegeneigdheid bijaraagt tot feitelijke medische consumptie. Medische consumptie wordt daarbij opgevat als elk contact met het "professionele systeem" a.w.z. met personen, die in de ogen van de raadplegende als medisch deskundigen kunnen worden beschouwd. Wij willen onder meer weter, of er verschilien zijn in de invloed van comsumptegenetgdheld tussen mensen die hun huisarts radplegen en mensen die een specialist consulteren. Bovendien zijn wij geinteresseerd in de vraag, of ziekenfondspatienten meer consumptiegenelgakela vertonen dan particulier-verzekerden alsmede in de eventuele sanenhang tussen consumptiegeneigraheld en bet raadplegen van alternatieve genezers. Deze zaken zijn niet eerder in studies naar dit onderwerp aan de orde gekomen. zij kunnen echter bijaragen tot 
het inzicht in de mogelijke oorzaken van vexschillen in medische consumptie tussen mensen.

In de derde plaats richt ons onderzoek zich op de mate waarin lenands gezinsleden of vrienden op zijn of hax consumptiegenelgdheid inwerken. Ter toelichting hierop voorlopig het volgende.

Aan een doktexsconsult gaat meestal een periode vooraf, warin men over de ervaren klacht nadenkt, ex eventueel zelf iets aan doet of mensen in zijn omgeving erover on raad vraagt. Afhankelijk van de aard wan de klacht kan het proces, dat uiteindelijk tot de beslissing leldt een arts op te zoeken, korter of langer duren. Verschliende onderzoekers hebben aangetoond, dat de Invloed van derden - gezinsleden, collega's, buren of vrienden - daarblj van groot belang kan zijn (Archer, 1967, Booth en Babchuk, 1972, Mc Kinlay, 1973, Walker, 1977). Ook zonder dat van een concrete ziekte-episode sprake is, belnvloeden mensen elkaar ju hun warden en normen betreffende gezondheid en ziekte. zij praten ex in het algemeen over, tonen zich ten opzichte van olkaar kleinzerig of juist stoer en bepaler op deze wijze de "cultuur van het lekennetwerk" (Freidson, 1961, Suchman, 1966, Langlie, 1977).

Deze onderlinge beinvloeding stat in onze studie centraal. wij baseren onze uitgangspunten op het werk van Freidson (1961, 1975). Wij wilien weten, of mensen uit een gezin of - ruimer gesteld - wit een lekennetwerk in hun consumptiegeneigdheid op e1kaar $11 j$ jer.

Tensilotte stellen wij de hierop aansluitende vraag, of deze eventuele onderlinge beinvloealng dan ook tot uitdrukking kont in hun medische consumptie: welke invloed hebben mensen in lemands directe sociale omgeving op zijn of haar gang naar de dokter?

1.3. De Indeling van het boek

Met het voorgaande is tegelijk al aangegeven, hoe het boek verder is ingedeeld. Het bevat vier delen, die telkens in het kort worden samengevat. De samenvattende hoofdstukken hebben de nummers $5,8,12$ en 15 . Het vijfde deel geeft een algemeen overzicht (hoofdstuk 16 ) en eindigt met enkele beschouwingen (hoofd- 
stuk 17).

Nast probleemstelling en literatuuroverzicht (hoofastuk 2) Wordt in het inleidende deel andacht besteed aan de onderzoekbaarheid van onze vraagstelling. Het zal blijken, dat wij on verschillende redenen voor een apriori duidelijk gerichte onderzoeksopzet hebben gekozen. Hoofdstuk 3 beziet de gevolgen daarvan. Het deel beslut met de beschrijuing wan die opzet en van de ultvoering van het onderzoek (hoofdstuk 4).

In deel II staat de consumptiegeneigaheid centraal: de wijze warop wij het begrip hebben geoperationaliseerd (hoofdstuk 6) en welke relaties er zijn tussen bepaalde ziektebeelden en consumptiegeneigaheid (hoofdstuk 7). Hoofdstuk 7 besteedt tevens aandacht aan de tweede onderzoeksvraag: in welke mate beinvloedt consumptiegeneigaheid iemands feitelijke medische consumptie?

Het derde deel gaat over het lekennetwerk. In hoofdstuk 9 wordt vooral de omvang ervan beschreven en in relatie gebracht met de consumptiegeneigdheid van de ondervraagden. Daarna (hoofdstuk 10) komt de vraag aan de orde, of leden wan het lekennetwerk onderling in consumptiegeneigdheid overeenstemmen en hoe ziy met elkaar ongaan met het oog op gezondheid en zlekte (hoofdstuk 11).

In het vierde en laatste deel wordt aandacht besteed an het professionele systeem. De relatie tussen consumptiegeneigdheld, netwexkkenmerkem en feltelijke medische consumptie komt daarin opnleuw en gedetailleerder aan de orde. Het gaat over de mogelijke verschilien in consumptiegeneigdheld tussen huisartsen specialistpatiënten (hoofdstuk 13) en over de consumptiegeneigdheid en de netwerkkenmerken in verband met overige vormen van medische consumptie (hoofdstuk 14).

Het boek eindigt - zoals gezegd - met een samenvattend en beschouwend overzicht (deel vijf).

NOOR ETJ HOOEDSTUK 1

1) Hior is wolstaan met de vermelding ven enkele vededanders, die hun onderzoek recentelijk publiceerden. 

Hoofdstuk 2: Probleemstelling en literaturaverzicht 2.1. Inleiding

In het vorige hoofdstuk is in het kort ingegaan op enkele belangrijke determinanten van medische consumptie. Naast het daar beschrewen model ter verklaring van doktexsconsulten zijn er echter ook andere benaderingen, die bij deze probieemstelling worden gevolgd. Mij willen daarvan in dit hoofdstuk een kort overzicht geven en tevens duideljjk maken, welk uitgangspunt voor deze studie is gekozen.

vooraf nog enkele opmerkingen over het begrip medische consumptie. Het wordt in deze studie opgevat als een bepalde vorm van gedrag in verband met gezondheid en ziekte, n1. gedrag warbij contact plaats heeft met het professionele systeem (Freidson, 19.75). De twee delen van deze definitie behoeven een korte toeLichting.

Over het algemeen worden in de medisch-sociologische literatuur onder gedrag in verband met gezondheid en ziekte vier gedragsvormen gerangschikt (Ras 1 en Cobb, 1966, Van der Maas, 1974, Lamberts, 1974, Kosa en Robertson, 1975). Dat zijn a) gezondheids- of preventief gedrag (een gezonde leefwijze, deelname an bevolkingsonderzoek e.a.), b) ziektegedrag in de betekenis van het zoeken van genezing als men zich onwel of andersins door ziekte bedreiga voelt, o) patiëntenrolgedrag als men ziek is en zlch als patiënt gedraagt en tenslotte d) probleemgedrag. Dat latste heeft te maken met het presenteren van psycho-sociale klachten, waraan geen duidelijk aanwijsbare pathologie ten grondslag ligt; of meer direct van bepalde problemen, die men niet zonder hulp van anderen meent te kunnen oplossen. In deze studie ligt de nadruk op het ziektegedrag en het patiëntenrolgearag. Wij komen daarop in hoofdstuk 3 nog terug.

In zijn boek "Profession of Medicine" gaat Freidson (1975) ütgebreid in op de kenmerken van het professionele system lpag. 71 e.v.). Daarbij is het voox ons doel van belang, dat er tussen (potentiële) patiënten en de leden van het professionele systeem een zeker verschil in sociale rang bestaat (Parsons, 1975, p.264, Van Doorn en Lammers, 1976, p. 73). 21j hebben alleen met elkaar contact omdat de professionele werker bepalde hulp of bepalde 
diensten te bieden heeft. In deze betekenis maken bijv. ook niet-universtalre genezers deel uit van het professionele system, ook al zijn zij in de meeste gevallen niet als genezer erkend. Dit, omdic zij de hen radplegende patient als hulpwerlener tegemoet treden en deze hun superioriteit op het gebied wan de te verlenen dienst exkent dan wel wil beproeven. Ardexzijds makt lemands vriend, die arts 1 doch niet als zijn (huis)arts optreedt, geen deel uit van het profesisionele systeem. In deze relatie zal ex immers nawwelijks van een sociaal rangverschil sprake zijn.

Wu kan blj alle vier genoemde gedragsvormen in verband met gezondheld en ziekte contact met het professionele systeem plats vinden: iemand kan zich laten inenten (preventief gedrag), hij kan genezing bij een huisarts of specialist zoeken(ziektegedrag). hij kan zich als patient doox en verpleegkundige laten verzorgen (patlëntenrolgedrag) en hij kan zijn problemen aan een maatschappelyjk werk (st) er of de huisarts voorleggen (probleengedrag). In al deze gevallen is ex sprake van medische consumptie. Deze opvatting van het begrip wijkt af van de definities, die ook het niet voorgeschreven medicijngebruik (zelfmedicatie) tot de medische consumptie rekenen. Wij kiezen voor deze afwijking omdat het contact van de patient met het professionele systeem voor onze probleemstelling - zoals verderop zal blijken - essentieel 15 .

Tot beslut nog eer latiste opmerking over medische consumptie. Gezien onze belangstelling voor de genelgdheid tot het gebruik van medische voorzieningen komt de nadruk in deze studie te liggen op die vormen van medische consumptie, die door de patiënt zelf zijn gejnitieerd. Veel bezoeken aan artsen vinden plats op grond van verwijzingen of voorgeschreven controles. De omvang van de medische consumptie wordt in Nederland dan ook mede bepald door kenmerken van het professionele systeem (Van der Gaag, 1978, Rutten, 1978, Van de Ven, 1980) wij besteden bier echter aleen andacht an medische consumptie warbij de patidnt een zekere besilssingswritheid heeft tot het inroepen van profesionele hulp. Deze vrijheid geldt: 
- de wijze warop de patient cen klacht percipieert; dere komt voort ult zijn belewing van zijn lichaam als psychom somatische entiteit (Bergsma, 1977);

- de wijze warop hij dat interpreteert in termen van zidke of geen 2 iekte:

- de wijze warop hij daarop reageert in termen wan zllektegearag of juist in termen wan "niets doen".

In de volgende paragrafen gaan wij hierop verder in. In hoofdstuk 4 zal worder beschreven, op welke manier enkele gegevens betretfende het professionele systeem in het onderzoek zijn opgenomen.

2.2. Verschillende modellen ter verklaring van medische comsumptie

2.2.1. Inleiding

De determinanten van medische consumptie zijn veelvuldig onderzocht en ook in verschillende literaturroverzichten bijeengebracht Mechanic, 1968 , Mc Kinlay, 1972, Kuyvenhoven en "rouwotten, 1976, Becker, 1977, Jonkers, 19781. Deze paragraaf kan darom beperkt blijven tot een beschrijving van de belangrjjkste modellen die ter verklaring van medische consumptie worden gehanteerd. Daarbij zillen wij aangeven, weike uitgangspunter wij voor ons onderzoek hebben gekazen.

Men kan ruwweg zes benaderingswijzen onderschelden, afhanke1ijk van de variabelen die daarin centraal staan, namelijk: (1) de sociaal-demografische of structurele benadering, die medische consumptie hoofdzakelijk wit persoonskenmerken tracht te verklaren, (2) de economische benadering, die de nadruk legt op het aanbod en de financieringswijze van medische voorzieningen, (3) de benadering aie vooral andacht besteed an de wijze warop de gezondheldszorg functioneert en tenslotte de naw met elkaar samenhangende (4) culturele, (3) de sociaci-psychologische en (6) de netwerk- of interactionele benadering. De onder (4) (6) genoemde benaderingen worden in de literatur ook wel samen onder de noemer "soclaal-cultureel" gerangschikt (Mc Kinlay, 1972, Kuywenhoven en Touw-otten, 1976).

De zes modellen worden uiteraard zellden "puru" toegepast, meestal vindt men mengvormen, waarin variabelen uit twee of meer 
modelien certral stan. Sommige auteurs onderscheiden nog een aparte vorr - "gedragmodel" genoend - waarin zoveel mogelijk variabelen ut de genoemde modelien tezamen in de analyse worden betrokken (Andersen, 1968, Kuyverihoven en Touw-otten, 1976). zo kan men de in hoofdstur 1 geciteerde studie van Cassee tot de gedragmodellen rekenen, ondat deze variabelen uit de benaderingem $1,4,5$ en ten dele ook 6 bevat.

onze vitgangspunten $z i j n$ voornamelijk op de onder 4,5 en 6 genoemde modellen gebaseerd, die wij daarom in het kort verder zullen toelichten.

\section{$2 n^{2}, 2$. De culturele benadexing}

Aan de beslissing tot het inroepen van medische hulp gat de vrag vooraf, of een bepaalde klacht ziekte is of lets anders. Bif de beantwoording ervan spellen algemene warden en normen ten aaritien wan gezondheid en zlekte een roll (Apple, 1960, King,1962, Twaddle, 1969). Het belang van culturele invloeden is bijvoorbeeld duidelijk aangetoond door Zola (1966, 1975), die verschilLen vond tussen Italtanen en Ieren in de wijze waarop deze klachten percipieerden en daarop reageerden met medische consumptie.

In onderzoek wordt veelal de nadruk gelegd op waarden en normen wan bepalde categorieên in de bevolking. zo besteden vele auteurs andacht an vexschillen bij de interpretatie van symptornem en bij de medische consumptie tussen naax social economische status onderscheiden groepen (Rosenblatt en suchman, 1964, Raphaëi, 1964, Horwitz, 1978). Suchman heeft in zijn onderzoeken verder vooral de nadruk gelegd op verschillen in ethnische achtergrond (Suchman, 1966). Voorts werd het belang van religieuze achtergronden vor verschilien in medische consumptie onderzocht (Langlie, 1977 ).

De algemene culturele invloeden vinden uiteraard hun weerslag in de attituden en opvattingen var (potentielle) patiënten en van mensen in hun airecte soclale ongeving. Hierdoor worden culturele verschijnselen vak tegelijk met sociaal-psychologische en/of netwekkenmerken op hun invloed bij medische consumptie anderzoolt. Daarbij speelt een rol dat algemene warden en normen, ontstan in het culturele inilien warvan men deeluitmakt, meestal op dezelfde wijze gemeten worden als specifieke attituden en opvatingen die voor het individu bepalde functies vervulien. 


\subsubsection{De sociaal-psychologische benadering}

onder de soolad1-psychologische benadexing worden versch1lende verklaringswijzen gerangschikt die gemeen hebben, dat het individu als potentiêle gebruiker van medische poorzieningen centraal stat. Zijn attituden en opvatingen krijgen dan een functionele betekenis. zij trachten medische consumptie te vexklaren uit iemands motivatie tot radplegen en/ot $z_{1 j n}$ medische kennis. Daarnaast kan de benadering, die medische consumptie opvat als "coping behavior" in reactie op stress op deze plaats worden genoemd (Howard en Scott, 1965, Mecharic, 1968, Van der Maas, 1974; zie hoofastuk 7, par. 7.5.).

volledigheidshalve vermelden wij op deze plats ook onderzoekers, die bij de verklaring van medische consumptie psychologische kenmerken benadrukken. Van dex ploeg (1.980) probeert de medische consumptie uit iemands persoonlijkheid te verklaren. Hi j veronderstelt, dat grootgebruikers andere persoonlijkheldseigenschappen bezitten dan kleingebruikers. zijn conclusie is everwel, aat ait slechts in beperkte nate bij een relatief kleine groep grootgebruikers het geval is. Voorts kan angst een rol spelen bij het inroepen van medische hulp. Daarbij moet wel onderscheid gemakt worden tussen een algemene angstidspositie en een specifieke angst ten gevolge van bepalide (dreigende) zlekter (Kosa en Robertson, 1975). Een gematigde angst zall het inroepen van medische hulp bevorderen, terwijl teveel en te wellig angst daarbij remmend kan werken (Kasl en Cobb, 1966).

In de literatuur treft men vrij veel onderzoeken aan, die op het zogenaamde "Health Belief Model" aljn gebaseerd (Rosenstock, 1966. Becker, 1977). Dit model gaat ervan uit, dat mensen alleen medische hulp inroepen als $21 j$ gemotiveerd $z$ ija

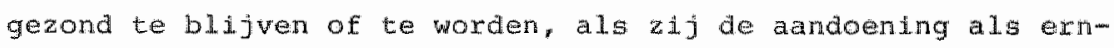
stig of dreigend percipiëren en als zij van medische hulp bat verwachten. Is er van een concrete aanleiding ("cue" of "trigger" , zola, 1964) sprake, dan zullen mensen die an deze voorwarden voldoen eerder medische hulp inroepen, dan mensen die daaran niet woldoen.

Het model is op verschiliende wijze geoperationaliseerd en beproefd (Hochbaum, 1958, Kegeles, 1963, Gochman, 1972, Kirscht, 1974, in Nederland vooral in verband met de vraag naar opkomst 
blj bevolkingsonderzoek, Sprult e. a., 1979, EVAC, 1980) "Het heeft tot op zekere hoogte $z$ ijn warae wel bewezen, dit zowel ter verklaring van preventief gedrag als van medische consumptie in vexband met dreigende ziekte (zie voor een kritische beschouwing Rosenstock, 1974). Sommige aspecten van het model zijn verder ultgewerkt en vooral $\mathrm{dn}$ samemhang met bepalde persoonskenmerken nader onderzocht (Ludwig en Gibson, 1969, Greenley en Mechanlc, 1976). Men kan aannemen, dat vooral de soclaal-economische status invloed op genoemde modelvariabelen heeft, zeker als het bij de modelafhankelijke varlabele om preventief gedrag gat. Personen uit hogere milieus hebben eerder motivaties tot gedrag dat hun gezondheid op langere termijn ten goede komt dan personen uit lagere milieus (Gochman, 1972, Rosenstock, 1974). vele onderzoekers hebben zich op attituden en opvattingen ten aanzien van medische zorg gericht (Stoeckle, 1963). Daarbit heeft Hulka $(1971,1975)$ aandacht besteed aan de tevredenheid met de axtsen. zij komt tot de cunclusie, dat er verschil bestat tussen iemands tevredenheld met de medische zorg in het algemeen en zijn tevredenheid met de eigen arts. De latutgenoemde is meestal grotex dan de eerstgenaemde. Uit vooral Amerikaanse studies blijkt verder, dat sceptische, niet-wetenschappe13jke opvattingen over gezondheid en de medische wetenschap mensen exvan weerhouden de arts te consulteren (Suchman, 1966. Geertsen e.a., 1975). Cassee (1973) vond in Nederland echter het tegenovergestelde: mensen met een txadicioneel-magische zlektebenadering maken juist veel gebruik van de huisarts. Over het algemeen kan men echter comcluderen, dat de invloed van houdingen en attituden op de medische consumptie nogal gering is. (Jessen, 1974, Kuyvenhoven en Touw-Otten, 1976.)

Tenslotte mag in dit verband het vele onderzoek naar de relatie tussen doktersbezoek en iemands medische kennis niet onvermeld blijven fFeldmann, 1966, Tagliacozzo, 1970, Giesberg e.a., 1977). De rol die mealsche kennis speelt is echter niet duldelijk. zij hangt weer samen met de invloed van opleiding of sodial-economische status op medische consumptie. Over het algemeen neemt de invioed van medische kennis af narmate andere matieven voor consumptie toenemen (Mc KInlay, 1972). 


\subsubsection{De interactionele of netwerkbenadering}

Een van de tekortkomingen van het soclaal-psychologische model heeft te maken met ae nogal eenzjaige nadruk op het individuele handelen. Daarblj wordt teveel uit het oog varloren, dat mensen door hun socialle omgeving beinvloed worden en dat $1 j$ de daarin geldende waarden en normen ten aanzien van medische zaken tot op zekere hoogte overnemen. Voorts gat an het besluit tot medische consumptie een proces vooraf, warin het individu veelal met adviezen en opmerkingen van derden wordt geconfronteerd die zijn besluit beinvloeden (Archer, 1967, Philipsen 1969 a).

De interactionele of netwerkbenadering houdt met deze bezwaren rekening. $\mathrm{Zij}$ is het meest duidelijk beschreven door Freidson (1975), die har tesamen met de culturele benadering in zijn denken centraal stelt. Hij gat uit van het feit, dat memsen deel uitmaken van sociale netwerken, die hun (ziekte)gedrag beinvloeden. Zowel de cultuur als de structuur van zo'n netwerk zijn van belang. Deze meer algemene gedachtengang (Bott, 1957, Mitchel1, 1969) komt toegepast op medische zaken op thet volgende neer.

De matstaven voor de beoordeling of men voor een bepalde klacht een arts moet raadplegen of niet, ontwikkelt men in wisselwerking met wat anderen - ouders, vrlenden, gezinsleden over gezondheid en ziekte zeggen of aan ziektegedrag vertonen. De specifieke opvattingen en attituden met betrekking tot medische zaken, die in het sociale netwerk gehanteerd worden, malken deel ult van de cultuur van dat netwerk.

ook in de reactie van netwerkleden op een concreet zlektegeval ("je ziet er slecht uit") weerspiegelt zich de cultuur van het netwerk. Mechanic spreekt in dit verband van "other-defined 11ness" in tegensteling tot "self-defined 11lness" (Mechando, 1968). Vaak neemt lemand niet eens zelf het besilut de arts op te zoeken, mar wordt hij door anderen gestuurd. Vandar de term "lay referral culture" (Freidson, 1961). "Lay" in tegengtelling tot professionele verwijzers, die deel uitmaken van het professionele systeem (zie paragraaf 2.1.).

Voorts is de netwerkstructuur medebepalend voor medische consumptie. Hechte netwerken "cohesive", "close-knit") worden 
veelal gekenmerkt door relatief veel sociale controle termijl gemakelijker leden van mer hechte netwerken ("extended", "Ioose-knit") hebben mensen in hun gang kunnen gaan (Bott, 1957). Voorts dan de elgen warden en nomen in aarraking te komen. Men kan nu viler en nomen in aarraking te komen. schelden, die door (idead) typen van lekennetwerken onder1.jkbare medische kla structuur-en cultuurkenmerken bij vergeconsumptie bewerke klachten verschillende niveau's van medische rolgt typeren.

1. Het hechte lekennetwerk, met opvattingen over ziekte en professionele opvattingen dienaangande. Hiex worden de minste doktersconsulten geteld, ondat mensen met dit soort opvatingen de arts weinig raadplegen (zie de hilervoor geDe onderlinge contan Suchman (1966) en Geertsen (1975)).

2. Het eveneens hechte van netwerkleden versterkt dit effect. wetenschappelijke gaan vaker naar de houding wordt adangenomen. De leden ervan typen netwerken. Deze twee typen worden ook wel (1) "Local" en (2) "cosmopolitan" gemeenschappen genoemd (Marton, 1957). Zij houden er (1) "parochDe twee andere typen $z$ in tussenvormen op na (Suchman, 1965). tie dan bij type (1) maar mincervormen met meex medische consumprige is darin alleen de le minder dan bij type (2). Voor het oveconsulten, ondat er minder onderlinge contend voor het aantal op hun (ziekte)gedrag plader onderlinge controle van netwerkleden schema 2.1.$)$.

Deze uitgangspunten zijn op verschillende manieren onderzocht (Raphä̈1, 1964, Geertsen e.d., 1975, Ben-Sira, 1977, Farge, 1978 ). Op het onderzoek van Raphä̈1 na bevestigen $z i j$ worden aangetekend, dat de tweede grote 1 ijnen. Daarbij moet wel. netwerken met medisch-wetenschepe extreme categorie - hechte te onderzoken betrekkelijk weinig 
Schema 2.1. PREDTCTED RATES OF UILIZATION OF PROFESSIONAL SERVICES, BY WARTATION IN LAY REFERPAL SYSTEE

\begin{tabular}{|c|c|c|}
\hline \multirow{2}{*}{$\begin{array}{l}\text { Lay peferal } \\
\text { structure }\end{array}$} & \multicolumn{2}{|c|}{ Lay Culture } \\
\hline & $\begin{array}{l}\text { Congruent } \\
\text { with Professional }\end{array}$ & $\begin{array}{l}\text { Incongramt } \\
\text { with profesifonal }\end{array}$ \\
\hline $\begin{array}{l}\text { Loose, } \\
\text { "Truncated }\end{array}$ & Medium to high utilization & Mecium to low wtildzation \\
\hline $\begin{array}{l}\text { Cohesive, } \\
\text { Extended }\end{array}$ & Higheste utilization & Lowest utilization \\
\hline
\end{tabular}

Bron: Freidson, Profession of Medicine, 1975, p. 294

In Nederland hebben Kuyvenhoven en Touw-otten (1978) de verschilien onderzocht tussen agrariers, autochtonen en forensen in de mate warain zij met een nieuwe andoening de huisarts consulteerden. zij veronderstelden, dat de bij het onderzoek betrokken agrariërs vergeleken konden worden met een meer "lacal" en de forensen met een meer "cosmopolitan" gemeenschap en dat de autochtonen een tussenpositie zouden innemen. ${ }^{2}$ ) De analyse was op registratiegegevens gebaseerd. Agrariërs bleken inderaad minder huisartscontacten voor hum rekening te nemen dan de andere twee groepen. Bovendien vertoonden kinderen van agrariërs minder nieuwe aandoeningen dan kinderen van autochtonen en deze weer minder dan kinderen van forensen. ${ }^{3)}$

In het verlengde hiervar staan studies, die aandacht besteden aan de functies, die netwerkleden in concrete ziektegevalien voor elkaar vervulien (Petroni, 1969. Froland, 1979). Booth en Babchuk (1972) onderschelden in dit verband instrumentele en expressieve functies. De eersten hebben betrekking op praktische hulp zoals bijwoorbeeld verpleegkundige veruchtirgen of het overnemen van taken van lemand, die deze wegens zlekte niet kan ultvoeren. Expressieve functies worden vervuld door personen, die vooral emotionele steun bieden bij ziekte. Veel onderzoek richt zich op de vraag, of bepallde netwerkleden verschillende functies vervulien (Van Doorn-Janssen, 1972, Sallowy en Dillon, 1973, Litman, 1974). Over het algemeen blijken familieleden beide typen functies te vervulien met de nadruk op expressieve as- 
pecten. Vrienden en kenrissen maken niet altija deel uit van een netwerk (M111ex, 1973, Bruhn, 1977). Als zij wel de rol van lekenadviseur vervullen is het meestal door middel var concrete adviezen of praktische hulp (van Doorn-Janssen, 1972, Booth en Babchuk, 1973).

\subsection{Conclusies: empirische en methodische aandachtspunten}

\subsubsection{Inletaling}

Zoals al utt de inlelding bleek en hierna verder zal worden toegellcht, richt zich deze studie tegelijk op de invloed van iemands houdingen en attituden ten aamien van medische zaken en op de invloed var iemands lekennetwexk op zijn medische consumptie. Bovendien zijn wij geinteresseerd in de relatie tussen deze twee: in welke mate beinvloeden leden van lekennetwerken onderling hur houdingen en attituden? Bij de witwerking erwan zullen wij op grond van het voorgaande de volgende aandachtspunten moeten verwerken.

\subsubsection{Het belang yan de aard van de aandoening}

Het spreekt vanzelf, dat het radalegen van de dokter sterk afhankelijk is van lemands vrijheid, om hem te consulteren. Die besilssingsvrijheid wordt in de eerste plaats bepaald door de urgentiegraad van de klacht (Hogerzeil, 1966, Philipsen, 1969a, Never, 1980). Iemand met een heupfractuur is niet vrij, lemand met griep is echter in hoge mate vrij, om tot een doktersbezoek te besluiten.

De invloed van bovenbeschreven sociaal-psychologische en netwerk-kenmerken op medische consumptie hangt eveneens af var de ara van de andoening (Stoeckle e.a., 1963). Temand met een ongeneeslijke zlekte $z$ al minder bat van medische hulp verwachten dan iemand met eer infectieziekte. En lekenadviseurs zulien anders op een veronderstelde heupfractuur reageren dan op griep. smlts toonde bijvoorbeeld aan, dat de door hem gevonden samenhang tussen het bij de huisarts gepresenteerde klachtenniveau van ouders en dat van hun kinderen bij ernstige gezondheidsstoornissen verawijnt. Die samenhang wijst op een gemeenschappelijke "cultumr" inzake het presenteren wan medische klachten bij 
de huisarts. De samehhang geldt volgens suls echter alleer voor aandoeningen, waarbij geen strikte noodzak - en dus veel besiissingsvrijheid - bestaat tot het inroepen van medische hulp (Smits, $1978, \mathrm{p}$ * 88 ).

Het belang wan de aard van de amdoening $x$ cht onze aandacht op een (a) empirisich en op een (b) methodisch punt. (ad a) De meeste bovengeciteerde studies naar de inwloed van lekennetwerken op raadpleeggedrag besteden aan de mogelijke verschillen op grond van de aard van de aandoening weinig aandacht. Zij baseren zich veelal op een a-selecte steekproef (Suchman, 1966, Geertsen e.a., 1975) of op een bepalde patientencategorie (Mc Kinlay, 1973, Finlayson, 1976). Wij willen daarentegen met ons onderzoek een verondersteld differentieel effect van verschillende ziekten op attituden en houdingen ten aanzien van medische zaken en op invloeden van lekenadviseurs opsporen. Dit sluit aan bij de suggesties van MC Kinlay (1972, p. 140). (ad b) Het methodische andachtspunt betreft het volgende. Het is gebleken, dat houdingen en attituden slechts geringe betekenis hebben voor de hoeveelheid medische consumptie, die lemand vertoont (Kuyvenhoven en Touw-otten, 1976, p. 39). Deze constatering werd vooral bevestigd door onderzoekers, die verschillende variabelencomplexen tegelijk bij de analyse betrokken (Andersen, 1968, Cassee, 1973, Jessen, 1974). Gegevens, die de aard van de andoening indiceren en daarmee de noodzaak voor een doktersbezoek weerspiegelen, bepalen het aantal consulten in zo sterke mate, dat andere gegevens daarbij een ondergeschikte rol spelen.

Als men nu toch iets wil weten over de attituden ten aanzien wan ziekte en gezondheid(szorg), dan 1ijkt het raadzani, de inwloed van de consumptienoodzaak zoweel mogelijk constant te houden. voox het onderzoek betekent dit, dat voor een gerichte opzet moet worden gekozen waxin het v66rkomen van bepalalde aandoeningen gelljk geschakeld is. Met de keuze voor zo'n onderzoeksopzet volgen ij het adwles van Freidson $(1975$, p. 294$)$ op. 
2.3.3. Het belang wan de wjze warop consunptiegeneigdheid geoperationa 1 seexd wordt

De ervaring van anderen leert ons, dat de wijze warop de sotal-psychologische variabelen worden geoperationaliseerd, de onderzoeksultkomsten nogal kan belnvloeden (vergelijke de reactie van Geertsen e. $\ldots ., 1975$, op Suchman"s onderzoek, alsmede Rosenwtock, 1974, Ben-sira, 1977, Farge, 1979, sprult e.a., 1979). Dit wordt bijzonder duidelijk in de studies van Jessen en van Cassee, die onder het begrip "consumptiegeneigdheid" persoonligkheidskenmerken, attituden ten aanzien van nogal uitcenlopende zaken, gedragsintenties en variabelen met betrekking tot zlektegevoel en ziektegedrag bijeenbrengen. Deze gegevens leiden tezamen tot geringe of moeilijk interpreteerbare resultaten (omedin Jessen, $1974, p$. 124).

Het is natuurlijk niet mogelijk, om aan te geven wat consumptiegenelgaheid nu "werkelijk" is. Wij volstaan op deze plats met de vermelding, dat het begrip consumptiegeneigdheid in deze studie niet met behulp van persoonlijkheidseigenschappen zal worden geoperationaliseerd ${ }^{4}$. . En voorts, dat wij het zulien baseren op meer algemene soclaal-psychologische theorieen over attituden, opvattingen en gedragsintenties. De keuze voor een ondexzoksopzet, warbij verschillende aandoeningen betrokken $z i j n$, vergemakkelijkt het operationaliseren van consumptiegeneigdheid, omdat met de onderzoeksvragen naar houdingen en attituden gerefereerd kan worden aan voor de respondent tot op zekere hoogte bekende zaken. In hoofdstuk 6 gaan wj daarop nader in.

Darap vooruitlopend formuleren wij hier alwast onze werkdefinitie van thet begrip consumptiegeneigdheid. Wij vatten deze op alls het geheel var opwattingem, attituden en gedragsintentes dat met medische consumptie te maken heeft.

\subsubsection{De afbakening van het lekennetwerk}

Freidson definieer het lekennetwerk als volgt (Freidson, 1961, p. 146): "The lay referral structure is one part of the lay referral system and consists in a network of consultants, potential or actual, runring from the intimate and most informal confines of the ruclear family through successively more select, 
distant, and authoritative persons until the "professional" is reached" "Daamee is echter niet aangegeven wie tot lemands "potential or actual lay consultants" gerekend kunnen worden. Het gaat om iemanas totale sociale relaties warran whehell zegt: "... it is usually necessary for pragnatic reasons to work with an identifiable set of persons and the relationships that exist among them". De preclese afbakening van het metwerk wordt aan de onderzoeker overgelaten (Mitchel1, 1969, p. 3-13).

In de literaturix wordt dit probleem op het terrein van gedrag in verband met gezonaheid en ziekte op twee te onderscheiden manieren opgelost. Sommige auteurs stellen een algemene netwerkinvloed central, warbij bepaalde netwerkkemmerken als mogelijke determinanten voor medische consumptile worden geinventariseerd. Mitchell noent een aantal criteria, wamee netwerken beschreven kunnen worden. Hij onderscheidt morphologlsche criteria, die het patroon van het netwerk beschrijven in termen van zijn ooxsprong of verankering "anchorage"), van dichtheid en omvang en van de mate warin de afzonderlijke netwerkleden voor elkaar berelkbaar zijn, en interactionele criteria. Deze laatsten zijn voor de meeste beschrijvingen belangrijker dan de eersten. Het gaat daarbij om de inhoud (een bepalade inhoud typeert een partieel netwerk) van het netwerk, om de wederkerigheid, de durraamheid en intensiteit van de onderlinge relaties en om de frequentie, warmee de leden met elkaar omgaan (Mitchell, 1969, p. $13 \mathrm{e} . \mathrm{v} .7$. Voorbeelden van studies, die deze criteria benadrukken zijn de onderzoeken van Winklex Prins (1966), Finlayson $(1976)^{5)}$ en Tolstorf (1976). Zij richten zich op de algemene invloed van "potential consultants".

De tweede benaderingswije richt zich op specifleke vormen van zlektegedrag of medische consumptie. Het gat daar om de invloed van netwerkleden op concrete situattes wan onwelbevinden, warin de patiënt bepaalde mensen om raad vraagt in verband met zijn klacht. Deze bepaalde mensen worden ook wel "slgnifldant others" genoemd (In dit verband door Mechanic, 1968). In studies hiernar wordt mensen die tot de een of andere vorm van meaische consumptie waren overgegaan gevraagd, wie zij voorafgaand an die consumptie hadden geraadpleegd (Booth en Babchuk, 1972, Miller, 1973). Deze studies blujven dus beperkt tot de "actual consultants" in termen vari Freldson. 
Nu zulien deze "signiflcant others" vaak dezelfde personen zijn die ook de meer algemene invloed op ziektegedrag en medische consumptie utoefenen, ni. gezinsleden of goede vrienden. Hun wnviod gat dan ook vak verder dan het adviseren omtrent het wel of niet consulteren van medisch deskundigen. zij vervulien in ex geval van ziekte ondexsteunende functies in die $z i n$, dat zij de patient geruststelien e.d.. De zlekte of klacht van de patient heeft daarom vaak ook conseguenties voor hun eigen gedrag. In geval van ziekte zijn zij meestal ook de aangewezen personen, die het recht van de patient op de patiëntenrol honoreren (Parsons, 1951, Freidson, 1962, Mechanic, 1968).

Het yolgende hoofdstuk gat daarop verder in.

wij kiezen ter afbakening van het soclale netwerk het volgende standpunt. Deze studie richt zich vooral op "significant others", behorend tot iemands primaire soclale netwerk (Bott, $1957)$ dile met betrekking tot allerlei medische zaken een algemene Invloed uttoefenen en die tevens het meest in aanmerking komen, om in concrete ziektegevallen als "actual consultants" op te treden. In termen van algemene theoriearn van sociale netwerken gaat het om netwerken met én specifieke inhoud (nI. "medische zaken"). Als zodanlg worden zij ook wel partiele of unlplexe netwerken genoemd (Barnes, 1969). Wij kunnen er op grond van het onderzoek van anderen echter vanuit gaan, dat deze netwerken ook vele andere "inhouden" kennen, ondat de netwerkleden tot elkaars primaire sociale relaties behoren booth en Babchuk, 1972, Miller, 1973, Froland, 1979).

2.3.5. De wijze waarop over netwerkleden informatie wordt ingewormen

Het valt op dat in de genoemde studies noolt personen zelf als lekemedviseurs in het onderzoek betrokken zijn. Informatie over lekenadviseurs wordt in de meeste gevallen via de respondent-patiënt ingewonnen. Dit gebeurt niet alleen in die studies die zich op de meer algemene invloed van lemands netwerk op zijn medische consumptie richten, maar ook in die studies die aandacht besteden aan de feitelijke adviseurs in een concreet geval van ziekte. In dit laatste geval was het immers mogelijk geweest, makkelijker dan in het eerste, on deze adviseurs mede in het onderzoek te betrekker. 
Wij achter dit een ernstig gemis. Een dergelijke werkwjize kan immers tot nadeel hebben, dat de via en respondent ingewonnen informatie ten gevolge van cognitieve dissonatie-reductie (Festinger, 1957, Rosemstock, 1966) vertekend is. Wij willen daarom bepaalde "signiflcant others" of "lekenadviseurs" zelf bij het onderzoek betrekken. Voor de meeste studies naar sociale netwerken is ait een gebruikelijke procedure (Nauta, 1973. Knipscheer, 1980, p. 28).

Eerder (paragraaf 2.3.2.) kozen wij voor een gexichte onderzoeksopzet, waarbij verschillende ziektebeelden zijn betrokken. Deze keuze kan tevens het aanwijzen van "lekenadviseurs" vergemakkelijken. Men kan ons inziens namelijk veronderstellen, dat in lekennetwerken van personen met duidelijk omschreven ziektebeelden al een selectie heeft platus gevonden van potentiele lekenadviseurs, die dan als "actual consmltants" bij de aandoening betrokken zijn. Het lekennetwerk heeft bovendien een meer concrete inhoud gekregen: de veelal welinig ulitgekristalliseerde opvattingen over gezondheid en medische zorg wullen in het geval van aanwijsbare ziekten zijn overgegaan in meer duldelijke denkbeelden daarover. Deze denkbeelden kunnen ontstaan, ondat de netwerkleden medische zaken bewuster zullen percipiëren en ex warschijnlijk wat meer over zulien denken.

\subsubsection{Tot besluit}

Tot zover enkele aandachtspunten voor deze studie naar aanleiding van het literatuuroverzicht. Alvorens deze in termen van onderzoeksvragen te herformulexen nog enkele opmerkingen over de social-psychologische en de netwerk-kenmerken in hun onderlinge samenhang.

Langlie (1977) heeft een poging gedaan, on de belangrijkste uitgangspunten van beide benaderingen in en onderzoek nax preventief gedrag samen te vatter. Hij vragt dok namelijk af, of sociaal-psychologische factoren nog wel een bijdrage leveren in de verklaring van preventief gedrag, als de kenmerken van iemands sociale omgeving ("social group characteristics") constant worden gehouden. Hij komt tat de conclusie, dat "both the health belief model and the socilal network model have significant unique effects as well as a jolnt impact on indirect risk preventive health behavior" (p. 254). 
onlangs kozen in vederland Spruit e.a. een vergelijkbare benadering in hun onderzoek naar de opkomst bij bevolkingsonderzoek op borstkanker in Leiden (Spruit e.a., 1979). Zij constateerden "dat zowel de sociaal-psychologische als de sociaalculturele (en sociaal-demografische) benadering aanijzingen opleveren voor factoren die met opkomst verband houden. "(Spruit, p. 784). Daarbij bleek de rol vari de Health Belief Model-variabelen minder duidelijk dan die van de sociale omgeving. Deze ihatste werd gemetren via verkregen steun bij de beslissing tot deelname aan het borstkankexonderzoek, via praten in de buurt er overleg met anderen over dat onderzoek en via lidmatschap van organdsaties en verenigingen (niet-komers waren minder vaak $1 \mathrm{dil}$ ).

Op grona hiervan kan men twee vragen stellem. Welke rol apelen sociaal-psychologische warlabelen en netwerk-kenmerken in een onderzoek naar ziektegedrag; zullen zij ook - evenals op preventief gedrag - op medische consumptie ten gevolge van (dreigende) ziekte eiger bijdragen in de variantieverkiaring leveren? In ten tweede: welke invloed oefent de sociale ongeving uit op Lemands opvattingen, attituden en gedragsintenties ten aanzien van medische consumptie; wat is de onderlingle relatie tussen sociaal-psychologische variabelen en netwerk-kenmerken?

\subsection{Probleemstelling en onderzoekbarheid}

Wij besluiten dit hoofdstuk door onze onderzoeksvragen preclezex dan in de inleiding te formuleren, alsmede door aan te geven, hoe de belangrijkste punten eruit onderzacht kumnen worden. In het volgende hoofdstuk wordt de anderzoeksopzet verder uitgewerkt zodanig, dat ten aanien van de resultaten enkele vooronderstelingen geformuleerd kunnen worden.

De probleemstelling valt in vier vrager uiteen.

1. Is ex sprake van een differentieel effect van verschillende andoentrigen op consumptiegeneigaheld?

Teneinde deze vraag te beantwoordsis is het noodzakelijk, verschiliende ziektebeelden in het onderzoek te betrekken. Het onderzoek richt zich daarom op personen, warvan bokend is, dat zij bepalde aamdoenirgen hebben. Wij veronderstelien, dat de mate var consumptiegeneigdheid afhan- 
kelijk is van nader te omschrijven kemmexken var die aandoenlngen, $\mathrm{nl}$. kenmerken, die mede voor de perceptie van de aandoening door de patient belangrijk zijn. Deze worden in het volgende hoofdstuk verder ultgewerkt.

Door verschiliende ziektebeelden in het onderzoek te betrekken, komen wij tevens tegemoet aan de eis, het woskomen van bepaalde aandoeningen gelijk te schakelen. Deze eis werd geformuleerd ondat het bij onderzoek nar de consumptiegeneigaheld raadzaam lijkt, om verschijnselen met betrekking tot de consumptienoodzaak zoveel mogelijk the elimineren.

2. Welke invloed heeft lemands consumptiegenelgaheid op aijn feitelijke medische consumptie?

Daarbij wordt medische consumptie als athankelijke variabele opgevat en geoperationaliseerd in termen van de rrequentie waarmee lemand efn of meer professionele hulpvexleners in verband met (dreigende) ziekte raadpleegt. De genelgdheid tot medische consumptie wordt onschreven als geheel van opvattingem, attituden en gedragsintenties, dat met medische consumptie te maken heeft. Hiervoor zij verder verwezen naar hoofdstuk 6.

3. Welke invloed hebben lekenadviseurs op de consumptiegeneigdheid?

Lekenadviseurs zijn personen die tot iemands primaire sociale netwerk behoren en die met betrekking tot medische zaken een algemene invloed uttoefenen. De respondent en zijin lekenadviseurs maken deel uit vam een lekennetwerk. Wekenadviseurs komen bij concrete ziektegevallen het meest in aanmerking, om als "actual comsultants" op te treden. Wij willen twee typen invloed onderschelden:

3.1. In welke mate komen opvatingen, attituden en gedragsintenties, die met medische consumptie te maken hebben, bimmen lekennetwerken overeen? wij veronderstelden, dat de leden van een lekennetwerk in hun cenkbeelden dienaangaande een zekere overeenkomst zullen vertonen. 
3.2. Welke invloed heeft hulp, geboden door lekenadviseurs, op de consumptiegeneigaheid wan de persoon in kwestie? onder hulp vestaan voor elkaar bil comcrete zlektegevalien vervulien. Vooruitlopeno op het volgende hoofdstuk veronderstellen wif. dat een bepalde mate van hulp lemands consumptiegeneigaheld kan doen afnemen.

4. Welke invloed hebben lekenadviseurs op iemands feitelijke medische consumptie; leveren de attituden, opvattingen en gedragsintenties een bijarage bij de frequentie warmee Lemand professionele hulpverleners consulteert? wij veronderstellen, dat iemands medische consumptie toeneemt naarmate $z i j n$ lekenadviseurs positiever tegenover de medische zorg staan. De opvattingen, attituden en gedragsintenties van lekenadviseurs worden in hoofdstuk 10 geoperationaliseerd.

Het volgende hoofdstuk bezlet de keuze voor en gerlchte onderzoeksopzet, 1.0. het onderzoeken van personen warvan bekend is, dat zij bepaalde andoeningen hebben op hatar consequenties voor de betekenis van

- consumptiegeneigdheid

- medische consumptie

- het lekennetwerk

in deze studie. Wij stelien de vraag, in welke mate die betekenis kan verschilien van de betekenis, die deze concepten hebben in een op min of meer gezonde mensen gerichte onderzoeksopzet. 
MOTEN BIJ HOOFDSTUR 2

1) De afhankelijke variabeje in Raphaels ondergoek betreft het inxoepen wan psychiatrische hulp. Dit kwail an tegensteling tot de verwachting het meest woor bij leden van open netwerken; orgeacht hun cultuur. Dit is wellicht te wijten aan een zeker taboe i. $w$.m. psychiatrische hulp en aan de operationaliseringen van structuur (d.m.v. "verhuisdzijn"y van cultur (d.m.v. opleiding).

2) Deze operationaliseringswijze illustreet de nauwe verwantschap van deze benadering met de eerder beschreven culturele benadering.

3) Bif een vergelijking van de medische consumptie van zijn patienten naar beroepsgroep kwan Ruhe al in 1958 tot de conclusie, dat notabelen in 1938 de meeste vexrichtingen voor hun rekening mamen en boeren de minste. Texwijl het aantal verrichtingen bij arbelders, midaenstanders en andatenaren tussen 1938 en 1954 sterk toenam tot ongeveer het niveau van de notabelen, bleven de boeren op het relatief lage pell van verrichtingen (Ruhe, 1958).

4) Maar daarmee naturuxlijk wel kan samenhangen; zij blijven evenwel buiten het kader van deze studie.

5) Findayson's onderzoek richt zfch op algemene netwerkinvloeden en tegelijk op specifieke invloedien van netwerkleden bij het zoeken naar hulp. overigens staat daarin niet het hulpzoekend gedrag van patirnten central, maar dat van hur echtgenoten. 

, 
Hoofdstuk 3: onderzoekbaarheld on herformulering

3.1. De ziektiebeelden in dit onderzoek

3.1.1. Inleiding

In het voorgaande kwam op verschillende punten de noodzazk tot een gerichte onderzoeksopzet naar voren. Hieronder zijn deze punten samengevat.

- Consumptiegeneigaheid is een van de determinanten van medische consumptie. Om deze beter te kumnen bestuderen is het $z$ invol, om andere, vooral de sterkere, determinanten waronder de consumptienoodzaak, zoveel mogelijk gelijk te schakelen.

- Om na te kumnen gaan, in welke mate consumptiegeneigdheld door concrete ziektebeelden wordt bepald is het noodzake1 ijk om verschiliende ziektebeelden in het onderzoek te betrekken.

- Het concept consumptiegeneigdheid is beter operationaliseerbaar als het aan concrete ziektebeelaen gerelateerd kan worden.

- Het lekensysteem in de zin varu Freidson is makkelijker ar te bakenen als menser met bepalde aandoeningen worden onderzocht.

In deze paragraaf vragen wij ons af, welke kenmexken de te selecteren ziektebeelden tegen de achtergrona wan de onderzoeksopzet idealiter moeten vertonen. Paragraaf 3.1.2. besteedt daaraan andacht naar aanleiding van wat de literatur erover leert. In paragraaf 3.1.3. kiezen wij drie zlektebeelden; daarbij besteden wij in het kort aandacht aan enkele algemene gegevens over de gekozen aandoeningen er aan de betekenis ervan voor da patiënt. Paragraaf 3.1.4. gat tenslotte in op de overweglngen voor die keuze in het licht wan het voorgande.

3.1.2. Criteria warmee ziektebeelden kunnei worden beoordeeld

In de literatuur wordt onderscheid gemakt tussen ziekte als de aanwezigheid van een aandoening ("disease"), als subjectief ervaren onwelbevinden ("illness") en als belemmerd-worden blj de dagelijkse bezigheden onder andere door de adnvararing 
wan de patichtenrol "sickness") (Philipsen, 1969 a, Van dex Mag, 1974). Op dat latste gaan wij in de volgende paragra nader in. Het verschil tussen de eerste twee vormen van ziekte suggereert een verschil in objectiviteit van criteria, warmee ziekte wordt beoordeeld. "Disease" is het objectief-medische begrip, "iliness" het door de patient zelf gepercipieerde ziektegevoel. Wij willen in dit kader niet verder ingaan op de veelbesproken problematiak rona de betekenis van deze ziektebegrippen, de verschuivingen extussen en de rol van de objectiviteit exblj. Recente studies besteden daaraan opnieuw ruime aandacht (Nederlands Hudsartsen Institut, 1979, deel I, Moll wan Charante, 1980, Ormel, 1980). Wij volstatan hier slechts met de volgende opmerking.

Howkl men "disease" en "illness" niet duldelijk van elkaar kan afbakenen, is dic onderscheid voor ons toch van belang. De in hoofastuk 2 genoemde studies, onder meer gebaseerd op het "Health Bellef Model" maken duidelijk, dat de door de patiënt gepercipleerde zlekte ("illness") van invloed kan zijn op zijn medische consumptie, ook zonder dat er sprake hoeft te zijn van "disease" In medisch-objectieve betekenis. Wij vatten de subjectief ervaren exnst van de ziekte voorzover deze niet duidelijk tot objectieve criterla herleid kan worden, dan ook in navolging van de "Health Belief Model"-auteurs op als een component van consumptiegeneigdheid.

Men kan erover twisten, of dit aspect tot de consumptiegeneigaheid moet worden gerekend. Sommigen vatten variabelen, die het ziektegevoel indicexen op als consumptienoodzaak. Cassee $(1973$, p. 46) definieert consumptienoodzaak als "de subjectief ervaren hoeveelheid en ernst van de aandoening en het daarbij optredende onwelbevinden". Wij zijn echter van mening. dat dat "deel" van het optredend onwelbevinden, dat niet door de "hoevelheid en ernst van de aandoening" kan worden verklaard, tot lemands consumptiegenelgaheid behoort. Het belangrijkste deel wan liemands zlektegevoel hangt immers samen mett structurele (persoons-) variabelen (Van der Maas, 1974, P. 19) en niet in de eerste plats met iemamas "abjectieve ziekte". Wle zich met de meting van ziekte en ziektegedrag bezig houdt weet echter, dat het niet echt mogelijk is, on deze zaken 
in een onderzoek te schelden. Verschillende studies wijzen daar expliciet op (ormel in Jessen, 1974, p. 122-124, Van der was, 1974, p. 19 en algemener: Pommer en Van Praag, 1978).

In hoofdstuk 6 kan men nagaan, hoe wij de houding ten aanzien van ziekte zoteel mogelijk onathankelijk van de "objectieve gezondheidstoestand" operationaliseerden. Hieronder noemen wij enkele criteria, die tot op zekere hoogte in "objectleve" termen gemeten kunnen worden. Deze zullen worden toegepast bij de selectie van enkele aandoeningen, die de consumptienoodzaak indiceren.

In het algemeen gaat het om kenmerken, dje (mede) door niet-medici kunmen worden gehanteerd. Dit, omdat wij onze informatie erover ook bij niet-medisch geschoolden moeten inwinmen en ondat wijzelf onvoldoende in staat zijn, on medisch-biologische criteria te formuleren en toe te passen. Welke criterla gebruikt iemana bij de beoordeling van verschijnselen als "ziek" of juist als "niet ziek"? Uit het onderzok naar deze vraag vallen de volgende kenmerken te destilleren.

(1) De duidelijkheid van een magelijke diagnose (Apple, 1960, Mechanic, 1968 ): keelpijn en koorts kunnen gemakkelijker als ziekte worden geinterpreteerd dan een vage pijn in de buik, zonder dat deze met verdere symptomen gepaard gaat. Hiermee naww verwant is de "rechtmatigheid" van de aandoening (Freidson, 1975). Giel zegt hierover: "Waar het om gaat is dat de ongeving de ziekenrol in een bepaald geval. meer of minder aanvardbaar vinat en er wel of geen voorwaarden en verplichtingen aan verbindt ..." (Giel, 1976, p. 1023). De betekenis van de ziekenrol komt, zoals gezegd, in de volgende paragrafen aan de orde. Hier wordt volstaan met twee an Giel ontleende voorbeelden voor de "reohtmatigheid" van een adndoening: een geestesziekte wordt veelal niet als "rechtmatig" erkend, zij heeft bij uitstek een stigma. Een ernstige hartilekte wordt daarentegen wel al ziekte exkend: de patient wordt onvoorwatardelijk alg "zleke" benadera (G1e1, 1976, p. 1023). 
Dit criterdum spreekt voor zichzelf, naar het is in vele gevalien wel voor interpretatie vatbaar. Is een darmstoornis bij een kind urgent of behoort deze tot de gewone kwaLen die bij kinderen nu eemaal kunnen optreden? Meestal wordt de urgentlegraad van een aandoening beoordeeld op grond van verschiliende criteria tegelijk. Om te voorkomen, dat de urgentie een subjectieve beoordelingmat wordt, spreken wj van de mate warin de aandoening levensbedreigend Is, pijn veroorzakt (Metz, 1975, Neven, 1980) en/of lemand blj zijn dagelijkse bezigheden belemert (Apple, 1960, Gordon, 1966, Philipsen, 1969 a, Twaddie, 1973). Men kan bij dit laatste onderscheid maken tussen fysieke en psychische belemmeringen.

(3) Het derde criterium dat in dit kader belangrijk is betreft de prognose var de aandoenting: gaat het om een kortdurende of om een chronische aandoening, warbij volledige genezing is uitgesloten (Gordon, 1966. Philipsen, 1969 a)? In samenhang hiermee - maar niet noodzakelijk ermee in overeenstemming - staat de hulp of verlichting die men van medische behandeling in verband met die aridoening kan verwachten. (Stoeckle, 1962, Kasl en Cobb, 1966.) Iemand met een intectlezlekte windt doorgaans meer baat bij geneesmidalen, dan ilemand met theura. Met medische behandeling $z i j n$ overigens niet bepaalde noodzakelijke controles bedoeld, zoals deze vaak voor bijvoorbeeld diabetici zijn voorgeschreven. Wij zullen beide punten - prognose en te verwachten bat bij behandeiling - gezien hun verwevenheid temamen behandeLen.

Deze kemmerken zijn tot op zekere hoogte objectiveerbaar, warbij wij antekenen, dat dit vooral bij de (psychische belemmering tot problemen kan leiden. Wanneer wij ziektebeelden voor het ondarzoek selecteren, moten zij met behulp van deze criteria duidelijk omschreven en ingedeeld kunnen worden. Voorts spelen de volgende methodische criteria bij de selectie per rol. 
(4) De ziektebeelden moeten binnen de Nederlanase bevolking relatief vaak voorkomen. Dit vergemakkelijkt de opsporing van (potentiële) deelnemers an het onderzoek en vergroot de reikwijate van de uitkomsten.

(5) Om de consumptienoodzaak constant te kunnen houden moeten zij aller een zekere mate van consumptienoodzaak tot gevolg hebben. Ook nadat de diagnose gesteld is moeten zij iri principe anleiding geven tot doktersbezoek.

(6) Wij moeten echter vooral verschillen in de mate waarin medische consumptie ten gevolge ervan noodzakelijk is. Alleen dan kan immers een eventueel differentieel effect van aandoeningen op consumptiegeneigdheid worden vastgesteld.

3.1.3. Drie ziektebeelden nader bezien

Het eerste criterium - de duidelijkheia van de diagnose (1) is ors inziens bij de selectie van aandoeningen in het kader van onze onderzoeksopzet het meest belangrijk. Het gaat daarbij immers om ziektebeelden, die zo "objectief" mogelijk vastgesteld kunnen worden, zodanig dat patiẻnten die aan deze aandoeningen $11 j d e n$, duldelijk kunnen worden onderscheiden van mensen die er niet aan lijden. Bovendien is vanuit onderzoekstechnisch oogpunt het wierde criterium - een relatief hoge prevalentie - belangrijk. Wij hebben op grond hiervan de voligende ziektebeelden geselecteerd:

- hartinfarct

- diabetes

- psoriasis (een huidaandoening)

Deze amdoeningen komen in Nederland vrij vaak woor loriterlum 4, zie hoofdstuk 4 voor epidemiologische gegevens) en geven alle drie in meerdere of mindere mate aanlelding tot medsche consumptie (criterium 5). De keuze is overigens tot op zekere hoogte willekeurig, ondat ook andere aandoiningen aan de genoemde criteria voldien. Deze paragraaf licht ale keuze nader toe. De inhoud is voornamelijk gebaseerd op de volgende studies: Duning, 1966, Doehrman, 1977. Nederiandse Hartstichting, 1974, Stern, 1976, Cowie, 1976. Angster, 1977 en Mi11er, 1977 woor 
hartinfaxctpatienten; Ardersen, 1963, De Moor en Witte, 1967 , Groer en De Loos, 1973, P1001j, 1977, Van der Rorst, 1980 , Wilte, a.m., DWN, Diabo, jrg. 32-34 voor diabetes; Hall, 1962 , Var Veen-vidutor, 1975, Van pelt, 1976, De korte (red.), 1977, NBPV-nieuws, le en 2 e jrg., Bremer-schulte (red.), 1980 voor psoriasis.

Het gat bij het volgende als het ware on de "gemidalde" patient met die ardoening. Darbij wordt noodzakelijkerwijs voorbijgegaan aan variaties binnen die aandoeningen. Voorts willen ij exop wijzer, dat elke indeling van ziekten op grond van "objectieve" criteria tekort doet an de eigenaardigheden van die ziekten en atan de kennerken van de individuele patiët die eraan lijdt. Binnen dit vitgangspunt is dan ook slechts een zeer globale beschrijving van de aandoeningen in genoemde termen mogelijk. Het elgenlijke onderzoek bledt echter de mogelijkheid, om bepalide hier niet verder uitgewerkte details nader te bestuderen.

Hoe kan men nu het (gehad) hebben van een hartinfarct, van diabetes of psoriasis met behulp van de overige $(\mathrm{nl}, 2,3$ en 6$)$ criteria beoordelen?

Urgentiegraad: Levensbedreiging, pijn en belemmering (2)

Een hartinfarctpatiënt is in levensgevaar geweest. HartInfarctpatiënten hebben dan ook een levensbedreigende aandoening, die weliswar kan genezen, maar die ten minste een lange tijd als een zeer ernstige ziekte moet worden gezien. Vele patienten biljven last houden van benauwdheden en hevige pijn op de borst ten gevolge van fysieke inspanning. Naw daarmee verweven is de angst voor pijn of voor een nieuw infarct. De mate van fysieke belemmering hangt af van de periode, die sinds het hartinfarct. verstreken $1 \mathrm{~s}$ en het succes, dat door revalidatie kon worden bereikt. De hartspier heeft ongeveer zes weken nodig am na het hartinfarct te herstellen (vorming van lidtekenweefsel).

Dlabetes behoeft - gezien de huldige stand van de redische wetenschip - miet langer levensbedreigend tee zijn. Dat neemt niet weg, dat het om een relatief ernstige zlekte gat, die nogal. strenge leefregels stelt, warbij "overtredingen" veelal duidelijke nadelige gevolgen voox de gezonaheldstoestand met zich meebrengen. Diabetici ondervinden echter geen pijn ten gevolge 
van de aandoening. $z 1 j$ worden warschijnlijk het meest belemmerd door de voorschriften ten aanzien van een regelmatige leefwijze. Bij alle extra inspaningen moten $21 j$ bovendien bedacht $21 j n$ op complicaties ten gevolge van de diabetes. Het contact net derden kan tot psychische belemmeringen aanlelalng zijn.

psoriasis tensiotte kan een ulterst hinderlijke aandoening zijn, levensbedreigend is zij echter nilet. zij veroorzakt geen pijn van betekenis. Psoriasispatienten ondervinden over het algemeen geen directe fysieke belemmering bij het verrichten van dagelijkse bezigheden. Hun aandoening belet hen in principe niet, om die dingen te doen die zij wllen doen. Mar dat is in de meeste gevallen niet los te zien van de psychische belasting, die deze huldziekte met zich mee kan brengen.

Prognose en te verwachten baat bij medische behandeling (3)

De indeling van de drie andoeningen naar ait kemmerk is minder gemakkel1jk, dan de indeling op grond van urgentlegraad. Het is wel duidelijk, dat diabetes tot de chronische, niet te genezen aandoeningen behoort. Suikerpatiënten kunnen echter in veel gevalien toch bat hebben bij geneeskundige behandelingen in verband met hun a andoening, bijvoorbeeld als zij opnieuw moeten worden ingesteld of andat zich complicaties voordoen, die te gemezen zijn.

Voor psoriasispatiënten zijn zowel de prognose van het verloop van hun aandoening als de te verwachten medische hulp daarbij onzeker. Over het algemeen verloopt de ziekte cyclisch, zonder dat van echte genezing sprake is en ook zonder dat medische behandeling daarop een wezenlijke invloed heeft. Mogelijke uitzonäeringen zijn darcbij de kurem in de Dode zee en de PuvAbehandelingen. Belde ajjn tot op heden echtex door een minderheli van psoriasispatiënten met succes gebruikt. Al met al zullen de meeste psoriasispatiënten moeten leren met hun a andoenlng te leven, zonder dat zij daarbij veel hoop op een gunstig verloop of op afdoende medische hulp kumnen rekenen.

Een hartinfarct tenslotte, kan door revalidatle wey; degelijk genezen zodanlg dat zich nawelijks meex restverschtjnselen voordoen. De door medische behandeling te verwachten hulp of verlichting is dan ook afhankelijk van het stadium warin het $z$ iekteproces zich bevindt. 
Conclusles ten aanzien van de consumptienoodzaak 16

Schema 3.1 vat het voorgaande samen.

schema 3.1. De geselecteerde zlektebeelden naar "objectieve" ziektecriteria

ziektecriteria

(1) datagnosie

(2) uxgentiegiad: relatief groot levensibedreiging, plin, belenime $x$ ing hateinfiret

vrij dnidelifk diabetes

zle ook hoofastuk 4
(3) prognosie on bate bils medische behandeling afrankeli $j k$ van stadilum ziekteproces relatief veel baat: niet zo groot gering andere aandoenin- geen levensbegen, complicaties areiging; geen van belang; geen pljn; nauwelijks pijn; tot op zeke- fysieke, wel re hoogte fysieke psychische been psychische be- lemmering lemering

ongeneesiljik, onzeker, relatief controles nodig; weinig bat tot op zekere hoagte baat.

op grond van de criteria 1,2 en 3 menen wij te kunnen steilen, dat hartinfarctpatiënten "objectief" gezien de meeste noodzaak voor medische consumptie zullen hebben. Fsoriasispatienten zullen daarentegen van deze drie categorieën de minste noodzaak daarvoor hebben. Diabetici tenslotte, nemen wat dit betreft warschijniljk een middenpositie in.

Wij zijn ons ervan bewust, dat bij deze indeling vele kanttekeningen te plaatsen zijn. zij besteedt zoals gezegd, vooral onvoldoende aandacht aan mogelijke gradaties van deze aandoeningen. Het i.s thmers zeer wel mogelijk, dat een hartinfarctpatient geen restverschijnselen meer ondervindt, alles weer kan doen en het infarct als het ware vergeten is; en dat iemand met psoxiasis zoveel hinder van $z i j n$ aandoening ondervindt, dat regelmatige medische behandeling noodzakelijk kan worden geacht. In de resteronde paragrafen van dit inleidende deel wordt op enkele mogelijke kantekeningen nadex ingegaan, met name daar, waar de selectie van te ondexzoken patienten met deze aandoeningen aan de orde komt (hoofdstuk 4).

Tot besluit nog een opmerking over de mogelijke relatie tussen persoonlijkheidskenmerken en deze aandoeningen. Dit onderzoek besteedt geen expliciete andacht an de eventuele samen- 
hang tussen persoonlijkheidsfactoren en (de geneigaheid tot) medische consumptie (zie paragraaf 2.3.2.). Er is echter veel aandacht besteed aan onderzoek naar de relatie tussen bepalde persoonlijkheidskenmerken en het hebben $c . q$. krijgen var een hartinfarct (bijv. Frledman e.a., 1967), diabetes (bijv. Groen en De Loos, 1973) respectievelijk psoriasis (bijv. Musaph, 1977) Deze persoonlijkheidsfactoren, die valgens sommigen met het optreden van de ziekten verband kunnen houden, kunnen ook van invloed zijn op de consumptiegeneigdheid van de patienten. Bij de interpretatie van onze gegevens zal hiemee - voorzover mogelijk rekening moeten worden gehouden. In dit verband gat het echter primair on de gevolgen van een aandoening en de betekenis, die deze voor de patiënten kan hebben.

\subsection{Gevolgen van de gekozen onderzoeksopzet voor de oorspron- kelijke probleemstelling}

\subsubsection{Inleiding}

Wij hebben orm verschillende redenem besloten, om het onderzoek op personen met een hartinfarct, met diabetes en met psoriasis en dus op chronische patiënten te richten. 1) Wij zullen daarom nu aandacht besteden aan de betekenis van patientenrolgedrag (als vorm var de eerdergenoemde "sickness") in het kader van deze studie. paragraaf 3.2.2. behandelt dit begrip in algemene zin. Vervolgens komt de vraag aan de orde, of door de onderzoeksopzet de betekenis van bepaalde concepten - vooral uiteraard het begrip consumptiegeneigdheid - is veranderd. Het gaat bij deze vraag niet om eventuele verschililen tussen de drie tee onderzoeken categorieän, maar om de mogelijkheid dat chronische patienten in het algemeen wezenlijk andere opvattingen etc. over medische zaken aanhangen (paragraaf 3.2.3.), wat medische consumptie" voor hen betekent (paragraaf 3.2.4.) en of lekennetwerken, warvan chronische patiënten deel witmaken wezenlijk verschillen van netwerken met (min of meer) gezonde leden (paragraaf 3.2 .5$.$) .$ 
3.2.2. Patidntenrolgedrag

In paragraaf 2.1. werd verschil gemakkt tussen gezondheidsof preventier gedragr ziektegedrag, patientenrolgedrag en probleemgedrag. $1 j$ stelden, dat medische consumptie zoals hier gedefinieerd, bij alle vier gedragswormen kan optreden en dat deze studie de Madruk legt op ziekte- en patiêntenrolgedrag. Bij zlektegedrag gat het on het zoeken van genezing bij (dreigende) ziekte (Kasi en Cobb, 1966, thilipsen, 1969a), bij patientenrolgedrag om het aanvaarden wan de patiëntenrol: ..."het beroep dat de zieke op zijn ongeving of de maatschappij doet om tijdelijk ontheven te worden van zijn matschappelijke verplichtingen (Phillpsen, 1969 a, p. 17).

In de medisch-sociologische literatur is veel aandacht besteed an de rol van de patient, mede naar anleiding van de oprattinger die Parsons (1951) hierover formuleerde. Hij begchriff daarin de rechten en plichten die an die rol vexbonden zouden zijn. In dit kader is een punt van kritiek op Parsons' ideeën hierover van belang, $n l$. dat deze maar in zeer beperkte mate betrekking hebben op patiënten met een chronische aandoening. Parsons concentreert zich op een tijdelijke rol terwijl chronische patiënten een permanente rol vervullen (Twaddle, 1969, freldson, 1975, Bruhn, 1977). Later heeft Parsons er zelf op gewezen, dat de rol van de chronische patiënt ".. becomes a parttime but not a totally absorbing role ..." (Parsons, 1975, p. 2701.

Dit wordt duidelijk, wanneer men $z i c h$ realiseert dat een ziekteproces verschillende fasen kent, die elkaar kunnen overlappen. Ienand met een chronische aandoening die beperkt weer aan het werk is, vertoont noch enkel patientenrolgedrag noch kan van hem gezegd worden dat hij hersteld in de matschapplj is teruggekeerd (Suchman, 1966, p. 114).

Tot op zekere hoogte kan de patient zelf beslissen, wanneer hij zich beroept op de rechten en plichten van de patiëntenrol en waneer hij dat juist niet doet. In verband net het hartInfarct merkt philipsen hierover op: "Iemand die herstelt van een hartinfarct, heeft juist omat men weet dat dit vele maanden zal duren, een aanzlenlijke vrijheid om zijn rolgedrag te bestendigen of niet; om het zoeken van hulp te verminderen of niet; 
om resterende klachten nog als gezondheldsprobleem te zien of niet." (Philipsen, $1969 \mathrm{a}$,p. 28).

Het gaat hierbij dus om de duur van een aandoening. Het voorgaande leert ons dat wij gezien onze oorspronkelijke probleemstelling patienten in het onderzoek moeten betrekken, van wie kan worden angenomen, dat $z i j$ de patientenrol in de enge betekenis van parsons (1951) tot op zekere hoogte weer hebben afgelegd.

\subsubsection{Consumptiegeneigdheid van chronische patiënten}

Het is zonder meer duidelijk dat het hebben van een chronische aandoening de geneigdheid tot medische consumptie sterk zal beînvloeden. Doordat men persoonlijk met ziekte, pijn en ongemak werd geconfronteerd, staat men waarschijnlijk anders tegenover dingen die met ziekte te maken hebben dan gezonde mensen. Men is bijvoorbeeld angstiger dan vroeger en besteedt meer andacht aan lichamelijke verschijnselen. Voor dit onderzoek is het van belang, of de consumptiegenelgaheid van chronische patiënten wezenlijk verschilt van die van gezonde mensen. Hierover zijn twee extreme opvattingen derkbaar.

Aan de ene kant kan men die vraag bevestigend beantwoorden (expliciet door Callahan e.a., 1966). Daarbij kan men zich beroepen op het feit, dat zeker de door ons bestudeerde chronische aandoeningen voor het leven wan de betrokkenen wo ingrijpend zijn, dat hun attituden, opvattingen en gedragsintenties in verband met medische consumptie daardoor een andere inhoud hebben gekregen. Om een woorbeeld te noemen: men kan het vertrouwen in de geneeskunde door zijn ervaringen verloren hebben en nu hulp gaan zoeken bij alternatieve genezers; lets wat men rogelijk afgekeurd zou hebben voordat men ziek wera.

In de tegenovergestelde opvatting wordt een wezenlijk verschil in consumptiegeneigaheid tussen chronische patienten en andere mensen afgewezen. Darbij speelt een rol, dat gezondheid in toenemende mate belangrijk wordt geacht: voor meer dar de helft van de Nederlanders is een goede gezondheld het belangrijkste in het leven (Sociaal en Cultureel Planbureau, 1980). De opvatting, die geen essentieel onderscheld tussen chronisch zieken en gezonden erkent 1 s gebaseerd op de veronderstelling, 
ad gezondheid wn het denken van vele - zieke an gezonde mengen nogal central stat doordat

- de meeste mensen tegenwoordig zelf bepalde ervaringen net ziekte en met een of meer vormen van medische zorg hebben opgedaan;

- de meeste mensen bovendien op verschillende manieren me ervaringen wan anderen op dat vlak in aanraking komen (naast gesprekken over gezondheid en ziekte met anderen ook via rubrieken in kranten en tijdschriften);

- er op het gebled van medische zaken in toenemende mate informatie wordt verstrekt.

Hierdoox zouden ook min of meer gezonde mensen bepaalde attituden etc. Over medische zaken hebben gevormd, die wel gradueel mar niet wezenlijk verschilien van overeenkomstige attituden van chronische patiêten. In het geval van een concrete zlekte-eplsode worden ook de opvattingen van tot op dat moment gezonde mensen gevormd en verder ontwikkeld. Parallel met het in paragraaf 3.2 .2 . beschreven graduele onderscheid tussen ziekte- en patientenrolgedrag zou ook het verschil in consumptiegeneigdheid tussen chronische patiëten en andere menser minder essentieel zijn dan het bijvoorbeeld door callahan e.a. werd geformileerd.

onze onderzoeksopzet kan de juistheid van een van beide opvattingen niet toetsen, omdat wij geen "gezonde" mensen in de studie hebben tetrokken. Dit - nast de eerdergenoende overwegingen (zie paragraf 3.1.1.) - mede omdat "gezonde" mensen in principe moellijk kunnen worden opgespoord. Men kan hen apriori hoogult kenmerken op grond van het feit, dat zij verschiljende aandoeningen niet hebben, maar moet tex bepaling van hun eventuele consumptienoodzak veel extra informatie inwinnen. Daarbij loopt men het risico, dat zij uiteindelijk toch een bepaalde (chronische) ziekte blijken te hebben (De Groot, 1968, p. 154).

Ter beantwooring van de vraag nar eventuele wezeniljke verschilien in consumptiegenelgaheid tussen chronisch zieke en gezonde mensen moeten wij dan ook naar nader onderzoek verwijzen. Wij wilen daarbij echter het volgende opmerken.

De tweedeling "chronisch zieke versus andere mensen" doet tekort an de zeer groot te achten verschilien tussen mensen en 
hun ziekten binnen de categorie chronische patienten. 21 Deze verschillen tussen chronische patienten onderling zouden echter in bepaalde gevallen groter kunnen zijn dan verschillen tussen een chronisch zieke en een gezonde. Men kan zich bljwoorbeeld voorstellen, dat een bepaalde psoriasispatient, die van deze huidziekte slechts tijdelijk en in gexinge mate last heef, meex overeenkomsten vertoont met een gezond persoon, dan met een zwaar getroffen hartinfarctpatiënt.

Wij achten dit onderscheid zinvoller dan de eventuele scheiding tussen chronische patiënten en andere mensen, omat daaruit meer begrip blijkt voor de aard en betekenis van een aandoening van al dan niet chronische ara. onze studie is dan ook onder meer gericht op de opsporing van verschilien tussen groepen mensen op grond van de aard en betekenis van hun zilekte.

\subsubsection{Medische consumptie van chronische patienten}

Er zijn twee naw verweven punten warop de medische consumptie van chronische patiënten kan verschillen van "gewone" medische consumptie. Het eerste heeft te maken met de reden voor een doktersconsult, het tweede met de mate van vrijheld om wel of juist niet tot alt consult te besluiten.

chronische patiënten kunnen om verschillende redenen een arts raadplegen en $z i j$ zijn daarbij in werschillende mate vrij om dat wel of niet te doen. zij kunnen tot medische consumptie overgaan voor

1. een voorgeschreven (controle-) consult in verband met de aandoening;

2 . een consult in verband met de aandoening op eigen initiatief:

3. (als restcategorie) een al dan niet voorgeschreven consult in verband met andere (dreigende) ziekte.

In de eerste twee gevalien gaat het om vervolgconsulten. Van de door ons te onderzoeken personen is immers alleen bepalde diagnose bekend, zodat elk doktersconsult in verband daarmee als verwolgconsult zal worden gereglstreerd. De beslissingsvrijheid bij zo'n consult is in het eerste geval zeer gexing: men kan hooguit besluiten am niet te gaan. ${ }^{3)}$ In het tweede en derde geval kan die vrijheid echter best groot zijn. 
2oals eerder werd opgemerkt, richt onze probleemsteling zich op medische consumptie ten gevolge van het elgen initiatief van de patient. In het onderzoek zal daarom voor voorgeschreven consulter moeten worden gecontroleerd.

Het verschil tussen de tweede en derde reden is minder strlkt dan uit de opsoming biljkt. Het gebeurt nl. nogal eens, dat emand voor een bepaalde klacht de dokter raadpleegt, maar dat hij dadrij in felte zijn bezorgaheid over een ander ongemak of probleem wil uiten. Dit kan vooral bij chronische patientuen makkelijk voorkomen en wel op twee manieren. zij hebben aan de ene kant met hun chronische aandoening een entré ("start-consult", Bremer en De Graaff, 1977) buj de dokter, dat zij kunnen gebruiken on andere zaken ter sprake te brengen. ${ }^{4)}$ Maar ook het omgekeerde is mogelijk. Temand kan tijdens een consult voox een griep of verwonding vragen stellen, die met zijn chronische aandoening verband houden. Daarmee vervaagt het verschil tussen de onder (2) en (3) genoemde redenen.

Er is nog een andere oorzaak wardoor dit verschil in het geval van chronische patiënten vervaagt. vele (areigende) ziekten kumnen immers verband houden met de aandoening in kwestie. vooral diabetioi hebber geleerd, dat lichamelijke afwijkingen van invloed kunnen zijn op de suikerzilekte (Plooij, 1977 ).

In het vervolg zal medische consumptie op grond van het voorgaande als volgt worden opgevat. Het gat on de frequentie wamee chronische patiënten met een lin hoofdistuk 4 nader te omschrijven) "professionele werker" contact hebben, waarbij voorgeschreven (controle-) contacten (statistisch) buiten beschouwing zullen blijven. In hoofdstuk 7 , paragraaf 3 , zal daaxbij in eerste instantie het verschil tussen consulten in verband met het hartinfarct, diabetes resp. psoriasis en consulten in verband met overige (dreigende) ziekten expliciet worden gematak $k$.

\subsubsection{Het lekenmetwerk van chrondsche patienten}

In paragraaf 2.3.3. wera over het lekennetwerk van chronische patienten in verband met de mogelijke afbakening ervan al het een en ander opgemerkt. Hier is de vraag aan de orde, in welke mate de veronderstelde invloed van lekenadviseurs op 
lemands consumptiegeneigaheid verschillend is, als men chromisch zieken en gezonden met elkar vergelijkt.

Met deze vraag komen wij terug op de betekenis van het patiëntenralgedrag (zie paragraaf 3.2 .2$.$) . Deze wordt nl. niet$ alleen bepald door de patiênt zelf mar mede voor een belangrijk deel door de mensen in zijn ongeving en hun verwachtingen ten aanzien van $2 i j n$ gedrag.

Gordon (1966) heeft aangetoond, dat er twee soorten verwachtingen bestaan ten aanzien van het gedrag van lemand die ziek is. Deze hangen vooral samen met de zekerheid diemen ontrent de prognose van de ziekte heeft. Nammate de prognose onzeker is, wordt de patiënt als afhankelijker en zorgbehoevender beschouwd dan wanneer omtrent de prognose enige duidelijkheid bestaat. Op grond van deze bevindingen makt Gordon een versohil tussen "sick-role" (patientengedrag in enge zin) en "impalredrole". Mensen die gezien worden als patienten wordt geadwiseerd, medische zorg op te zoeken, zij krijgen extra andacht en verzorging van hun medemensen en zij worden van hun eigen verantwoordelijkheden ontheven. De "impaired" zouden daarentegen veel meer worden aangemoedigd, zelfstandig en onafhankelijk te $z i j n$, niet teveel over hun ziekte te praten en zich daaromtrent geen extra zorgen te maken.

De geleidelijke overgang van patientenrol in enge zin naar de rol van iemand met een chronische handicap (Tellegen, 1975) wordt dus als het ware weerspiegeld in de verwachtingen van medemensen ten aanzien van die rol. Philipsen (1969a, p. 22) zegt hierover: "Iemand die in een chronische toestand van onwe1bevinden verkeert, wegens vroegere ziektegevallen, maar die niet chronisch en volledig de rol van de patiënt heeft aanvara, wordt ... niet als zdek beschouwd maar als gehandicapt." "

Wat kan men nu zeggen over eventuele verschillende invloeden van lekenadviseurs op chronische patiénten vergeleken met lekenadviseurs van gezonden? Men kan darover in felte niet meer en niet minder zeggen, dan wat hiervoor over patienterrolgedrag in het algemeen (paragraaf 3.2.2.) en aver consumptiegenelgdheid werd vermeld (paragraaf 3.2 .3$. ). Naarmate de ziekte langer durt en de patiant de "impaired-role" heeft aangeromen, kan het gedrag van zijn lekenadviseur vergelijkbaar zijn met het overeen- 
konstige gedrag van lemand, die deel witmaakt van een lekennetwerk net alleen gezonde mensen. Daarbij kunnen zich wel verschilien tussen de adviseurs wan ae drie patientencategorieën vorrdoen.

De chronische handicap kam wel anleiding zijn tot bepalde activiteiten van de patient eri zijn medemensen, die zonder zo"n handicap niet waren verricht. Daarbij valt te denken an veel wandelen of fletsen (in lekennetwerken met een hartinfarctpatlent), aan het gemeenschappelijk volgen van een voorgeschreven dieet (1dem: diabeet) of aan het helpen inzalven (idem: psorlasispatient). Voorts valt te denken àn meer emotionele steun door bijvoorbeeld een gesprek over de problemen, die de aandoening met zich meebreng*.

Wh verwachten dat (in hoofdstuk 11 nader te omschrijven) hulp en steun van lekenadviseurs in deze "role-support" Salloway en Dillon, 1973, p. 134) de consumptiegeneigdheid van de patient zullen doen afnemen. Deze geaachte is gebaseerd op de veronderstelling van o.m. Scott en Howard (1970) warin deze auteurs aan informele hulpbronnen een probleemoplossend effect taekennen. Het is niet uitgesloten, dat informele hulp ook de geneigaheid om een gezondheldsprobleern door een doktersbezoek te willen oplossen, kunnen doen afremen.

Daarblj noet wel worden aangetekend, dat de veronderste1ling van scott en Howard ook in Nederland op uiteenlopende wijzen is onderzocht zorder dat zij duidelijk kon worden bevestigd (Sociaal en cultureel Rapport 1978, Van Eijk, 1979, Ormel, 1980). Het lijkt de moeite waxd om haar opnieuw te toetsen.

\subsection{Hypothesen}

Het voorgaande geeft anleiding tot het formuleren van enkele te verwachten onderzoeksresultaten. 5) Daarbij sluiter wij a bij de vier onderzoeksvragen ult paragraaf 2.4. ad I: Is ex sprake van een differentieel effect van verschillende andoemingen op consumptiegeneigaheid?

Wij verwachten een positieve samenhang tussen consumptienoodzaak en consumptiegeneigdheid en verwachten dexhalve cat 
1.1. hartinfarctpatienten de sterkste en psoriasispatienten de geringste geneigdheld tot medische consumptie zullen vextonen; voorts, dat diabetici wat dit betreft een tussenpasitie zullen innemen.

Wij baseren deze verwachting op de hiervoor rader toegelichte veronderstelling, dat de noodzaak voor medische consumptie doorgaans groter is voor hartinfarctpatienten dan voor diabetici. en dat deze voor hen weer groter is dan voor psoriasispatiënten. Voorts verwachten wij dat

1.2. de consumptiegeneigdheid geringer zal ajin narmate de aandoening langex duurt (en zich geen conplicaties voordoen).

Deze veronderstelling is gebaseerd op de gedachte dat ten gevolge van een langere ziekteduur een zekere gewenning aan de aandoening $z a l$ optreden, waardoor de geneigdheid tot het consulteren van de arts afneemt (Neven, 1980).

ad 2: Welke invloed heeft iemands consumptiegeneigdheid op zijn Eeitelijke meaische consumptie?

op grond van onze onderzoeksopzet kan men verwachten dat

- de algemene invloed van consumptiegeneigaheid op feitelijke medische consumptie in dit onderzoek groot geacht kan worden.

ad 3: Welke invloed hebben lekenadviseurs op de consumptiegeneigdhetd?

Wij veronderstelden al een grote mate van overeenkomst tussen de patiënt en zijn lekenadviseurs in attituden, opvattingen en gledragsintenties met betrekking tot medische consumptie. Wij verwachten op grond van het voorgaand dat

3.1. Lekenadviseurs van personen met verschillende aandoeningen in hun attituden ten aanzien van medische consumptie zu len verschilien; deze verschilen zullen parallel lopen aan de bij hypothese 1.1. veronderstelde verschilien tussem patiëntencategurieën;

3.2. Lekenadviseurs, die de patiënt in praktische of emotionele zin helpen, zullen zijn consumptiegeneigdheld doen afnemen. 
ad 4: 1 ine 1 wolod hebben lekenadviseurs op lemands feitelijke medische consumptle?

Het voorgaande qeeft geen anleiding on onze eerdere verwachting hieromerent te specificeren: wij verwachten dat

- Lemands medische consumptie toeneent nar mate zijn lekenadviseurs positiever tegenover de medische zorg staan

(de precieze betekenis van dat laatste komt in hoofdstuk 10 an de orde).

Tot zover de belangrijkste onderzoekshypothesen. Voor zover de studie daarop betrekking heeft, krijgt het onderzoek tot op zekere hoogte en toetsend karakter. Tot op zekere hoogte woora1, omdat het statisch van aard is en daarmee geen uitspraken toelat over de volgorde warin verschijnselen optreden. Om bijvoorbeeld hypothese 2 te kunneri toetsen, zou men eerst informatie wilen inwinnen ontrent iemands consumptiegeneigaheid, alvorens op een later tijdstip vragen te stellen over zijn medische consumptiv.

Afgezien darvan heeft het onderzoek wel kenmerken var een experimentele opzet: factoren warvan verwacht kan worden dat zij de afhankelijke variabele (hier: medische consumptie) sterk bieinvloeden (hier: consumptienoodzaak) zijn gelijk geschakeld. Daarbinnen is ruimte gelaten, om een eventueel differentieel effect van die factoren aan het licht te brengen. Op basis van een dergelijk onderzoek kan worden aangegeven of de veronderstelde verbanden gelden onder de condities, die in de onderzoeksopzet zijn vastgelegd (Philipsen, 1969 b).

NOTEN H.IJ GOOFDSTUK 3

1) In strikte zin zijn personen die en hattnfarct hebben gehad geen chrontsche patianten, omat if weer in eren toestand zondar restweschijusen kunnen komen. Wij achten de gevolgen van een haxt-

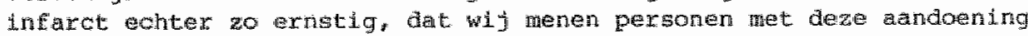
mat onfonische patianten te kunnen vergelijken.

2) Deze opmerking is aok ls kritiek geplaatst bij parson's theorieên ontrant patentenrolgedrag: wechten en plichten van de patient ajo in hoge mate afharkelijk van de ara van ajo an andoening (Gordon, 1966, Freidson, 1975 ).

3) Met de studie zou op zinvolle wijze andacht kumen worden besteed atan het probleem van "non-compliamce" (Davis, 1967, stimson, 1974) van vexschillende patientencategorieen. Dit aspect werd echter niet verder vitguwerkt. 
4 Dit is vexgelijkbar wet het "stutconsult" dat ap grond van plicontroles (Lamberts, 1975 ) of op grond van de ziekte wan evind (van der velden, 1971) wordt gebruikt, om de dokter voor andere $/$ eigen gezondheidsklachten of problenen om advies te wragen.

5) Bij aeze formuleringen geldt de "ceteris paribus clausule" ale daaxin gemakshalve ndet expliclet is opgenomer. 
Hoofdstuk 4: onderzoeksopzet en -uitwoexing

4.1. Inleiding

Dit hoofdstuk beschrijft de opsporing en selectie van te onderzoeken personen (paragraaf 4.2.). Daarbij komen de volgende andachtspunten (opnieuw) aan de orde, tw.:

- de duwr van de aandoening:

- persoonskenmerken warvan kan worden aangenomen "dat

zij de medische consumptie op bepalde wijze belnwloeden;

- de veronderstelde consumptienoodzaak van alle drie patiëntencategorieën.

In paragraaf 4.3. komt de operationalisering van het lekennetwerk en in paragraaf 4.4. de operationalisering van het professionele systeem aan de orde. Het hoofdstuk besluit met een korte beschrijving van de onderzoeksvoorberelding.

\subsection{De te ondervragen personen}

4.2.1. Opsporing van hartinfarct-, suiker-en psoriasispatienten

Hoe kan men patienten met genoemde aandoeningen opsporen? wij hebben gemeend, ons hiervoor in eerste instamtie te kunnen baseren op door personen zelf gerapporteexae ziekten. Deze methode heeft het nadeel, dat zij subjectief ervaren $z$ Lekten aan het licht brengt, die soms niet tot objectieve aandoeningen te herleiden zijn. Bovendien worden op deze wijze niet alle objectief vaststelbare ziekten gerapporteerd, bijv. omdat de persoon er geen weet van heeft of er niet over wil praten conlangs opnleuw belicht door Garrity, 1978).

over het algemeen is de kans op onderrapportage via deze methode groter dan de kans op overrapportage (Cassee, 1973 op grond van vijf bronnen, Elinson en Trussell, 1957).

Genoemae bezwaren zullen echter minder wegen naarmate de te rapporteren aandoening onjectief vaststelbar en met behulp van een ook voor niet-medici duldelijk te begrijpen diagnose te omschrijven is. Dat is hier het geval. Het voordeel van deze boven andere methoden is, dat in principe elke patientu die van zijn aandoening op de hoogte is een kans heeft, om voor het onderzoek in aanmerking te komen. Een selectie door reglstrerende axtsen of zlekenhuizen zou bevooroordeeld kunnen $z 1 j n$, bij- 
vooxbeeld omdat deze registratles worden opgezet en bijgehouden vanult en hulpverlenergperspecties of ondat zij alleen recente gegevens bevatten; hieraoor zouden vroegere gevallen apriori bulten het onderzoek blijven.

Om personen met de drke aandoeningen op te sporen werd gebruik gemakt van de Omibus Service van de N.V. v/h Nederlandse stickting voor statistiek. Daarbij worden per week bij ca. 1200 a-select gekozen hulshoudens gesprekken over verschillende onderwerpen gevoerd. In het adressenkader voor deze steekproef 21 in hulshoudens van oudere mensen die in een bejaardenoord wonen ondervertegenwoordigd, omdat de trekkingskans veela 1 het oord doch niet zijn bewoners geldt.

Gedurende vier weken werd in totaal bif 4950 huishoudens de wraag gesteld, of ex of meer leden van het huishouden een (of meex) met name genoemde andoeninger hebber. op deze wijze werden 196 hartinfarctpatienten, 160 diabetici en 53 personen met psoriasis opgespoord. ${ }^{1)}$ op grond hiervan zou men voor NederIand tot de volgende schattingen komen: 186.000 hartinfarctpatiënten (1,33), ruim 152,000 diabeten $(1,098)$ en ongeveer 50.000 psoriasispatiënten $(0,36$. 2)

om iets over de betrouwbarheid van de opsoningsmethode te zeggen, zulien wij deze gegevens met landelijke cijfers over het vobrkomen van genoemde aandoeningen vergelijken. ook hiervoor bestaan uiteraard alleen schattingen (Tabel 4.1.).

Tabe 1 4.1. Geschat vóbrkomen van genoemde aardoeningen in Nederland (in percentages van het aantal inwoners)

$\begin{array}{cccccc}\text { hartinfaret }^{1)} & \begin{array}{c}\text { omnibus } \\ (1970-72)\end{array} & \begin{array}{c}\text { diabetes } \\ (1978 / 79)\end{array} & \begin{array}{c}\text { onsibus } \\ (1976 / 79)\end{array} & \begin{array}{c}\text { psoriasts } \\ (1975 / 80)\end{array} & \begin{array}{c}\text { omibus } \\ (1978 / 79)\end{array} \\ 0,3 & 1,3 & 2 \text { a } 2,5 & 1,1 & 1 \text { a } 2 & 0,4\end{array}$

1) C.B.B./M.N.O., 1980, p. 91

2) Ploolj en Lutjens, 1976, p. 25/Van de Horst en Meulders, 1980

3) Bremer en De Grafe, 1977, p. $17 /$ Dullex, 1980

Hierbif moet men bedenken, dat vooral de gegevens met betrekking tot het aantal hartinfaretpatienten nogal veroudera $z i j n^{3}$ ? Vergelijkt men bijwoorbeeld het aratal ziekenhuisopnamen ten gevolge van en acuut myocardinfarct in de pexioden 1969-1972 en 1973-176, dan valt een stijging wan ruim 19 op (C.B.S. en 
TNo). Ondanks dit lijkt het aantal opgespoorde hartinfarctpatienten nogal hoog, terwijl de andere twee groepen warschijnlijk ondervertegenwoordigd zijn. Dit laatste komt overeen met de eerdergenoemde bevinding, at zelfrapportage eerder tot onder- dan tot overschatting van het vorkmom van aandoeningen leldt. Waarom sporen wij dan relatief zoveel hartinfarctpatienten op? Dit moet vermoedelijk vooral worden toegeschreven adn het feit, dat ook andere hartklachten door de patienten veelal als hartinfarct geinterpreteerd worden. Wij hebben dit tot op zekere hoogte voorzien en in het opsporingsonderzoek de vraag toegevoegd, of men voor het hartinfarct in het ziekenhuis had gelegen. Dit met het doel, het aantal "onterechte" haxtinfarctpatiênten te reduceren. Op deze vraag antwoordden 164 personen bevestigend. Als men alleen deze ondervraagden als hartinfarctpatienten in aanmerking neemt, is hun aantal nog aan de hoge kant. Nu is uit gegevens van het C.B.S. af te leiden, dat patiënten die met de diagnose: "symptomen en slecht omschreven toestanden" worden ontslagen, veelal waren opgenomen met een vermoed hartinfarct (of om er zeker van te zijn, dat een hartinfarct als aiagnose kon worden uitgesloten) 4) Het is best aannemelijk, dat de patiënt deze ontslagdiagnose niet kent, vergeten is of door de ervaring, voor een (vermoedelijk) hartinfarct te zijn opgenomen denkt, ook werkelijk een infarct gehad te hebben.

Hoe het ook zij, wij moeten bij onze verdere analyses bedenken, dat in dit onderzoek alleen diabeticl en psoriasispatienten tot onderrapportage, hartinfarctpatiënten darentegen tot overrapportage neigden. Onderrapportage werd mogelijk mede veroorzakt door genoemde ondervertegenwoordigling van ouderen. onder hen beyinden zich immers veel chronische patienter.

De diagnose "hartinfarct" bleek bij nader inzlen wermoedelijk minder duidelijk dan werd verondersteld. Het verschyl tussen objectieve diagnose en subjectief ervaren ziekte zou juist bij deze categorie relatief groot kunnen zijn (Garrity, 1978, Levine en Kozloff, 1978). 5)

over de aldus opgespoorde personen werd tijdens de omnlbusenguete de volgende informatie ingewonnen: geslacht, leeftijd, duur van de aandoening en een indicator voor de mate warin de 
andoening bij de persoon in kwestie optreedt. Voox hartinfarctpatienten werd - zoals gezegd - gevraagd, of men in verband met het hartinfarct In het ziekenhuls had gelegen en bovendien, in welke mate men nu weer dagelijkse bezigheden (werk, huishouden) kon verichten. Voor suikerpaticnten werd gevraagd, in welke mate de ziekte regelbaar is. Aan psoriasispatienten werd tensitute direct gevraaga, of men de ziekte in lichte, wisselende of heftige mate had.

Deze operationaliseringen zijn aangepast aan de beperkingen, die een opsporingsprocedure vla de omibus-service oplegt: de interviewwagen moeten zonder verdere toelichting door enquetrices en respondenten begrepen kumen worden en het aantal.

Tabe1 4.2.1. Gegevens betxeffende hartinfarctpatienten

abs. perc.

ges lacht:

man

vronsw

leeftije

$<34 j x$.

$35-49 \mathrm{j} x$.

$16 \quad 8$

$50-64 j \dot{j}$.

$77 \quad 40$

$65 \mathrm{jr}$. e.o.

heeft vanwege h.i. in

zlekenhuls gelegen

ja

neen

geen antwoora
164

mate warim men vroegere bezllgheden nog kan ultoefenen

holenali niet meer

mincer intengidef

werer thet als vroeger

weet niet

pexlode verstreken sinds

(1.atsie) martinfarct

<1 Jas

1-5 Jaar

$>5$ Jaar

weet niet

Totall
$61 \quad 31$

8443

$43 \quad 22$

34

84

16

- 
Tabe1 4.2.2. Gegevens betreffende sukerpatidnten

abs. pere.

geslacht

जatath

Wrow:

6138

9962

Leetidu

$\begin{array}{llr}<34 j \mathrm{jr} & 11 & 7 \\ 35-49 \mathrm{jr} & 15 & 9 \\ 50-64 \mathrm{jr} . & 57 & 36 \\ 65 \mathrm{jr} \cdot .0 . & 77 & 40\end{array}$

recte ibaarheid suikerzicke

makk lijk

wisse lemd

$112 \quad 70$

moei injk

weet niet/geen antwoora

$23 \quad 10$

$\begin{array}{rr}16 & 10 \\ 9 & 6\end{array}$

periode verstreken sinds wien weet

dat sulkerzliekte geconstraterd lis

$<151$.

$1-5 j \mathrm{j}$.

$>5 \mathrm{jk}$.

weet niet

\begin{tabular}{rr}
13 & 0 \\
65 & 41 \\
71 & 44 \\
11 & 7 \\
\hline 160 & 100
\end{tabular}

Totall.

Tabel 4.2.3. Geqevens betwefiende psoxiasisatienten

gessacht

abs. perc.

man

583

vrour

Ieertijd

$<34 \mathrm{jr}$.

35-49 jx.

$50-54 j x_{*}$

65 jr. e. o.

$\begin{array}{rr}16 & 30 \\ 19 & 36 \\ 8 & 15 \\ 10 & 19\end{array}$

mate warin men

psorias heest

in lichte mate

28

wisselend of tamelith erg

in heftige wate

weet niet

$\begin{array}{rr}21 & 40 \\ 3 & 0 \\ 1 & 1\end{array}$

pertode verstreken sinds

pariasis gecontatererd is

< 1 j $r$ *

$1-5 j r$.

$x+5 \mathrm{j} x$.

weet niet

\begin{tabular}{rr}
2 & 4 \\
7 & 13 \\
39 & 74 \\
5 & 9 \\
\hline 53 & 100
\end{tabular}

Totade

$53 \quad 100$ 
uragen mot tot een uiterste minimum worden beperk. Hierdoor werd voor de "urgentiegraad" van de andoening voor de ene patidutencategorie en ander criterium angelegd, dar voor de andere. Deze zijn dam ook onderling riet goed vergelijkbaar. Tabel 4.2. bevat, voor elke patientencategorie afzonderlijk, de belangrijkste opsporingsresultater.

renslotte werd gevragd of deze personen eventueel bereia zouder zijn, om aan een onderzoek deel te nemen met als onderwerp de betekenis van het leven met bepaalde aandoeningen yoor de patient en zijn medemensen. Omdat deze bereidheid voor het elgenlijke onderzoek belangrijk kan zijn, werd zij mader bezien.

Het bleek dat noch de duur en exnst van de aandoening, noch het geslacht en de leeftijd van de patiënt (per patientencategorie en voor alle respondenten tezamen getoetst) significant samenhingen met de bereldheid tot medewerking aan verder onderzoek. Alleen sulkerpatienten zijn dartoe minder bereid dan hartinfarctpatiëten. (Tabel 4.3. )

Tabel 4.3. Eerel theid tot verdex onderzoek naar patientencategorie

\begin{tabular}{|c|c|c|c|c|c|c|}
\hline \multirow[b]{2}{*}{ wel bereld } & \multicolumn{2}{|c|}{$\mathrm{HII}$} & \multicolumn{2}{|c|}{ s } & \multicolumn{2}{|c|}{$\mathbf{p}$} \\
\hline & $\begin{array}{l}\text { abs. } \\
150\end{array}$ & $\begin{array}{c}\text { pere. } \\
77\end{array}$ & $\begin{array}{l}\text { abs. } \\
101\end{array}$ & $\begin{array}{c}\text { perc. } \\
63\end{array}$ & $\begin{array}{c}\text { abs. } \\
36\end{array}$ & $\begin{array}{c}\text { perc. } \\
60\end{array}$ \\
\hline weet nog niet & 6 & 3 & 14 & 9 & 5 & 9 \\
\hline niet bereid & 40 & 20 & 45 & 28 & 12 & 23 \\
\hline tota. I. & 196 & 100 & 160 & 100 & 53 & 100 \\
\hline & $x^{2}=$ & $0.3 \mathrm{p}$ & $.05^{11}$ & & & \\
\hline
\end{tabular}

1) woor het totall en voox telkens twee patientencategorieern getoetst: psoriasispatianten verschillen op alt punt noch van aibetici noch wan hartinfarctpatienten.

\subsubsection{Selectie van de te ondervagen personen}

De Irieiding sonde arie aandachtspunten op, die bij de selectie van te ondervragen personen wan belang zijh. Het eerste betrett de dur van de aandoening. In hoofdstuk 3 is nar voren gekomen, dat bij chronische patienten een zekere gewenning an de ziekte kan optreden narmate deze langer duurt; en dat daarmee de kans toeneemt, dat zij de patiëntenrol in enge 
zin hebben afgelega. Vandar, dat wj patienten wilen selecteren, die al relatief lang weten, dat zij een hatinfarct, diabetes resp. psoriasis hebben (gehad).

Het weede aandachtspunt betreft persoonskentierken, die op medische consumptie van invloed kumnen $z i j n$. Ten arnzien daarvan veronderstellen wij het volgende.

- Ouderen, vrouwen en personen met een lagere soolale status maken (ceteris paribus) meer gebruik vam medische voorzieningen dan jongeren, resp. mannen en mensen uit hogere milieus.

Dit blijkt uit welhast alle onderzoeken op ait gebled. Met betrekking tot ouderen en vrouwen is dit wel in te $z$ ien, maar de Invloed van social economische status op medische consumptie kent vexschillende facetten. Wij verwijzen hiervoor naar recente overzichten (De Jong, red., 1980, Van de Ven e.a., 1981). Voorzover mogelijk zullen wij ook deze variabelen in het onderzoek gelijkschakelen.

Bij het derde aandachtspunt gat het on de veronderstelde consumptienoodzaak van zowel hartinfarct-, suikerziekte- als psoriasispatiënten. Om deze zoveel mogelijk te warborgem, selecteerden wij op grond wan de eerdergenaemde indicatoren voor de mate warin de arandoening optreedt de "meest ernstig zieke" pátiënten.

Het verzamelde materiaal bood de mogelijkheid om per patientencategorie voldoende bereidwillige personen te vinden en deze zelfs nog volgens de meeste van de genoemde critería te selecteren. Dit gebeurde als volgt.

- De duur van de andoening. Personen die pas een jaar of kortex geleden hebben gehoord, dat ze aandoening in kwestie hadden, kwamen in eerste plaats niet voor het vervolgonderzoek in anmerking. Als eerste werden personen geselecteerd, die de andoening al langer dan viff jaar hadden, omdat mag worden angenomen, dat $z_{1 j}$ dan de belangrijkste ervaring met hun zlekte of de gevolgen daarvan hebben opgedaan.

- Leeftijd. Het lag in de bedoeling on deze zoveel nogelijk geiljk te schakelen. Tegelijk zouden echter zo min mogelijk oudere mensen an het definitieve onderzoek moeten deelne- 
men, on de kans te verkleinen dat nast de aandoening in kwestie andere chronische $z$ iekten het beeld zouden verstoren. Bij de selectie van suikerpatienten moest bovendien worden vookomen, dat zich onder hen uitsluitend ouderdomsdiabetici zouden bevinden.

Als belangrijkste criterium werden in eerste instantie pexsonen van boven de 70 jaar voor deelname an het onderzoek ultesloten. Bij suikerpatiënten werd de maximale leeftijd op 64 jaar gesteld. Als tweede criterium gold een ondergrens van 16 jaar om geen kinderen in het onderzoek te moeten betrekken. Tussen deze twee grenzen werden personen "zo jong mogelijk" geselecteerd.

- Geslacht. Het bleek niet mogelijk om - voor gelijkschakeling - of alleen vrouwen of alleen mannen in het onderzoek te betrekken. Wij besloten daarom, binnen de drie patiëntencategorieen zoveel mogelijk een evenredige verdeling na te streven zodanig, dat de variabele geslacht in de analyse zou kunnen worden gebruikt.

- "Ernst" van de aandoening (gemeten volgens de eerdergenoemde indicatoren). Alle hartinfarctpatienten, die in verband met het hartinfarct niet in het ziekenhuis hadden gelegen, werden apriori buiten het onderzoek gehouden. Hiermee moet - zoals gezeqd - zoveel mogelijk worden voorkomen dat zich onder de te onderzoeken personen mensen bevinden die - on welke reden dan ook - ten onrechte opgaven, een hartinfarct te hebben gehad. Voorts werd bij dit criterium geselecteerd van "ernstig" naar "licht" zodat de meest ernstige gevallen (volgens opgave van de respondenten althans) an het onderzoek zotden deelnemen.

- Social economigch status. Deze kon bij de selectle geen rol meer spelen. Wij besloten, on de laatst genoten opleiding van de respondent als variabele in de analyse te betrekken.

Op grond van deze criteria werden driemaal 25 personen geselecteerd woor het eigeniljke onderzoek. Het veldwerk geschiedde in de eerste drie maanden van 1979 door special daarwoor geInstrueerde enguetrices van het Instituut poor Toegepaste socio- 
logle (zle ook paragraf 4.5.). De medewerking van de respondenten was goed "zodat slechts enkele adressen moesten worden vervangen. 6) De samenstelling van de onderzochte groep volgens de aangegeven selectiecriteria is weergegeven in tabel 4.4 .

Tabel 4.4. Respondenten naar andoening en maar voorar als selectiecriteria gehanteerde kenmerken (absolute aantalien)

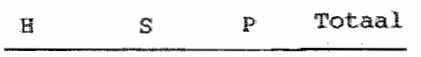

1. Duur yam de arandoening

$$
\begin{aligned}
& <1 \text { jaar } \\
& 1-5 \text { jaar } \\
& >5 \text { jaar }
\end{aligned}
$$

$\begin{array}{rrrr}- & 1 & 1 & 2 \\ 15 & 6 & 2 & 23 \\ 10 & 18 & 22 & 50 \\ & & \end{array}$

2. Leeftija

$16-34$ ปaax

$35-49$ jaar

$50-64$ jaar

$65-72$ jaar

$\begin{array}{rrrr}- & 5 & 4 & 9 \\ 6 & 5 & 14 & 25 \\ 16 & 15 & 2 & 33 \\ 3 & - & 5 & 8 \\ & & & \\ & F=5.67 & p<.01\end{array}$

3. Geslacht

mannen

vrouwen

$\begin{array}{ccccr}16 & 13 & 16 & 45 \\ 9 & 12 & 9 & 30 \\ & x^{2}=1.0 & \text { N.S. }\end{array}$

4. "Ernst" van de aandoening"

$\begin{array}{lrrrr}\text { licht } & 5 & 15 & 12 & 32 \\ \text { wisselend/thatig } & 9 & 4 & 8 & 21 \\ \text { ernstig } & 11 & 6 & 5 & 22 \\ & & & & \\ & & x^{2}=9.76 & \mathbb{P}<.05\end{array}$

1) $n$ : licht werricht dagelijkse bezigheden weer het als voor hartinfiarct wisselend/matig = verxicht dagelijkse bezigheden minder intensief exnstig = verricht aagelijkse bezigheden helemaa niet meer

$s$ : Suikerziekte is gewoonlijk makkelijk (= licht) / wisgelend/ moelilijk (= ernstig) regelbaar

$P$ : heeft psoriasis in lichte mate ( $=$ licht) / wisselend / tamelijk arg of in heftige mate (= ernstig) 
De patlërtencategoriën versch1llen onderling significant in leeftijd en in de dux van hun aandoening lde "ernst" var de a andoening is voor de categorieen niet zonder meer vergelijkbaar, zle noot bij tabel 4.4.). Gezien onze opzet, on bepalide factoren in het onderzoek gelijk te schakelen, roept alt twee ragen op, nl. (1) wat is de aorzak van deze verschillen? en (2) welke betekents hebben $z$ ij voor het verdere snderzoek?

De oorzaak van de verschilien is toe te schrijven an het relatief geringe aantel opgespoorde personen per categorie. dat voldeed aan de combinatie van genoemde kenmerken. Hartinfarctpatiënten $z i j n$ in het algemeen nu eenmaal ouder dan psoriasispatiënten, zekex als bovendien de eis gesteld worct, dat $z i j$ het hartinfarct al relatief lang geleden gehad moeten hebben. De opsporing had vele maanden langer moeten duren om op dit punt betere resultaten te bereiken. Ons inziens woog deze extra inspanning nilet op tegen de nadelen, die de hier geconstateerde verschillen met zich meebrengen. Wij komen hiermee op het antwoord op de tweede zoëven gencemde vraag.

Bij de selectie van respondenten stond voorop dat zo min mogelijk ouderen en zo min mogelijk personen die nog maar kort ziek zijn, gekozen zouden worden. Aan deze els kon op redelijke wijze worden voldaan. voor analyses die op alle respondenten betrekking hebben en roor analyses pex patientencategorie geldt dan ook, dat belangrijke determinanten wan medische consumptie zoveel mogelijk onder controle zijn gehouden of - zoals bij geslacht - als variabele in de analyse kunnen worden betrokken. Bij de interpretatie van verschillen tussen patientencategorieën kan met de hler geconstateerde verschilien rekening worden gehowden.

\subsection{Het lekennetwerk}

zoals gezegd: bij dit onderzok zijn ook die personen actief betrokken, die deel uitmaken van het lekensysteem van de respondenten: ook met hen werden - ulteraard met explidiet gevraagde en verkregen toesteming van de patiët - vraaggesprekken gevoerd. Deze personen zijn opgespoord door de respondenten 
ongeveer halverwege het gesprek de volgende twee vragen voor te leggen:

1. Mu is het lets anders of lemand alleen weet dat 0 een hartinfarct gehad hebt of dat iemand er maw bij betrokken is. $\mathrm{y}$ praat bijv. met lemand over de hinder die o ervan ondervindt en de problemen die $U$ er misschien mee hebt. Iemand, die $\mathrm{v}$ ook helpt met allerlei kleinere, praktische of grotere problemen in verband met Uw aandoening. Nu zou ik graag van U willen weten wie vam Uw gezinsleder, hulsgenoten, familieleden, vrienden, kenissen, collega's of buren het meest bij Uw aandoening betrokken is?

2. En wie is dat op de tweede plaats, wie is daarna degene die het meest bij Uw aandoening betrokken is? Welke relatie hebt $U$ met hem/har?

Wij beperken het te ondervragen antal lekenadviseurs tot twee. Gezien de bevindingen van Booth en Babchuk (1972), M11er (1973), Litman (1974) en Finlayson (1976) 11jkt dit alleszins gerechtvaardigd.

De enquetrices werd met nadruk verzocht, d6or te vragen als then niemand of slechts Eén persoon kon noemen. In deel III gaan wij op de kermerken van het lekensystem uitgebreid in. Daarop vooruitlopend geeft tabel 4.5 alvast een overzicht van het antal lekenadviseurs dat door de verschillende patientengroepen werd genoemd.

Tabe1 4.5. Aantal lekenadviseurs genoend, naar patiëntencategorie

twee personen genoemd sllechts sen persoon genoma nulland genowa

toitaal

\begin{tabular}{rrrr}
$H$ & $S$ & $P$ & Total \\
\hline 19 & 17 & 8 & 44 \\
6 & 8 & 15 & 29 \\
- & - & 2 & 2 \\
\hline 25 & 25 & 25 & 75
\end{tabular}

$$
x^{2}=13.3 . p<.04
$$

Psoriasispatiënten noenen minder lekenadviseurs dan de andere twee patiẻntencategorieủn. Op de mogelujke interpretatie hiervan komen wij in hoofdstuk 9 terug. 
zin er wel verschillen tussen patientencitegorieen voor wat betreft het adntal genoeme lekenawiseurs, aj verschilien onderling niet of muwelijks in de relatie die zij met de genoemde personen hebben. 62 var de 73 angewezen "belangrijkste betrokkenen ${ }^{*}$ ijn echtgenoot, echtgenote of verloofae van de respondent, de overige $11 \mathrm{zijn}$ andere gezins- of familieleden. 4 moeders, I vader, 5 dochters en een zuster. Ook als tweede betrokkenen werden vooral familieleden genoemd, nl. 7 ouders, 23 kinderen en 9 overlge familieleden. Slechts wijf lekenadviseurs zijn geen familielid wan de respondent max 21 in of hav butryrouw of -man, vilend (in) of kennis.

De In totaal 117 genoemde personen konden niet in alle gewallen worden ondervraga omdat sommigen van hen onbereikbaar waren. Ex zijn 111 gesprekken met lekenadviseurs gevoerd, 72 net de belangrijkste en 39 met de daarna belangrijkste betrokkene.

4. 4. Het professionele systeem

Per patient is telkens ook een lid van het professionele systeem bij het onderzoek betrokken. Dit vooral. om de op zelErapportage berustende gegevens over de aandoening te kumen aanvullen door meer "objectieve" gegevens. Omdat het om chronische patienten gat, was het niet zonder meer duidelijk, welke professionele werker hiervoor moest worden aangewezen: de behardelend specialist, de huisarts, de dietiste?

Besloten is, in elk geval een arts bij het onderzoek te betrekken. Welke arts dat zou zijn werd aan de patient-respondent zelf overgelaten en wel in eerste instantie via het antwoord op de volgende vraag:

Als $U$ voor diabetes (het hartinfarct / psoriasisy behandeld wilt worden of advies wilt hebben, gat u dan nar uw huisarts, nat Jw specialist of nat een andere gezondheidswerther?

Op deze vraag bleef de antwoordmogelijkheld meen andere gezomdhetaswerker, nI. ...." onbenut, zodat de instructie t.a.v. de te benaderen arts voor deze gevallen hier onvermeld blijven. In 30 gevalien werd de hulsarts genoend, in 4 een specialist. Een respondent zei, noolt met wellke arts dan ook contact te hebben. 
De verdeling nar de aard van de andoenimg is in tabel 4.6 . te zien. Wij merken op dat $z$ tch geen verschillen voordoen tussen de drie groepen voor wat betreft het aantal genoemae huisartsen en specialisten. Deze gegevens worden verder in deel IV behandela.

Tabe1 4.6. Door patient-respondent genoemde "professionele werkexs" naar aaxa van de aandoening

\begin{tabular}{|c|c|c|c|c|}
\hline & $\mathrm{B}$ & $\mathrm{s}$ & $p$ & Totaal \\
\hline ritemand genoemd & - & - & 1 & 1 \\
\hline hujsarts genoemd & 10 & 11 & 9 & 30 \\
\hline speclalist genoend & 15 & 14 & 15 & 44 \\
\hline totaal & 25 & 25 & 25 & 75 \\
\hline
\end{tabular}

Het $\mathrm{lag}$ in de bedoeling on het oordeel van de artsen over de ernst van de andoening in medische zin en over de noodzakelijk geachte controlefrequentie bij de analyse te betrekken. Daarnaasit was het belangrijk om te weten, of de respondent nog andere aandoeningen heeft, die zijn medische consumptie kunnen beinvloeden. Deze infarmatie werd - eveneens na expliciet gevraagde en verkregen ${ }^{7)}$ toestemming van de respondent - via een schriftelijke vragenlijst bij de artsen verzameld. Een respondent wilde deze toesteming wiet geven omdat aijn arts het naar eigen oordeel "al aruk genoeg heeft". Van de 73 verstuurde lijsten werden er 58 terugontvangen $(79.4$. 8 ). Dit aantal is uitzonderlijk hoog. De ervaring leert immers, dat schriftelijk onderzoek in het algemeen een respons van ten hoogste 45 a 50 oplevert (Gadourek 1967, p. 201).

De reacties verschilien echter wel per patientencategorle. wij ontvingen 21 van de 24 psortasis-, 22 van de 24 diabetesen slechts 15 van de 25 hartinfarctijsten terug. Het $\mathbb{1} s$ niet onwarschijnlijk, dat dit samenhangt met de eerdex gesugnaleerde overrapportage bij hartinfarctpatienten. Het merendeel van de lijsten bevatte volledige, soms additionelle informatie over hetgeen er gevraagd werd. 


\section{5. onderzoks voorberelaing}

Wil besteden een aparte paragrat aan de onderzoeksvoorbexelding, ondat deze natr onze mening woox het onderzoek nogal belangrijk is geweest. In hoofdstuk 6 zal blijken, hoe met name de consumptiegeneigdheid van de patient is geoperationaliseerd en vertadid 4 interviewragen. Daaraan voorafgaand $z i j n$ deze en lle andere vragen op verschiliende wiye getest.

De vragenijster bevatten aandoemingsspecifieke delen en delen, die ook met gezonde mensen besproken kumen worden. De specifieke delen zijn ter beoprdeling voorgelegd an personen, die ten aanzien van beleving wan deze aandoeningen door de patidnt deskundigheid bezitten. 9 De vragenlijsten (arie voor patient-respondenten en arie voor hun lekenadviseurs) zijn ultelndelijk in arie fasen op hun begrijpelijkheid voor de respondent beoordeeld.

Een eerste versie is door de onderzoekster witgetest in proefinterviews met zeven wllekevige, bereidwillige respondenten dit de verschillende patientengroepen en met telkens een van hun lekenadviseurs. Een tweede versie is an een audiovisuele test onderworpen (Hout en Wester, 1977). Deze werd door net Institut voor Toegepaste Sociologie (I.T.S.) uitgevoera. Hiervoor stelden zich drie respondenten en telkens een doox henzelf aangewezen lekenadviseur bereidwillig beschikbaar. Tenslotte werd een derde versie gebrulkt voor drie proefgesprekken, die gevoerd werden in de situatie wan het eigenlijke onderzoek met via het omibus-onderzoek opgespoorde patient-respondenten en hun tijdens het gesprek aangewezen lekenadviseurs. Dexe interviews werden door interviewsters van het I.T.S. gehouden en samen met hen geëvalueerd.

Deze fasegewijze voorberelding heeft het mogelijk gemaakt, met de verschillende vragen en opmerkingen van respondenten en interviewers in de defintieve vragendijten rekening te houden. Dit heeft er mede toe bijgedragen, dat de "echte" interwiews door de meeste interviewsters en respondenten positief werden extraren. 


\section{NOTEH BIT HOOPDSTUK 4}

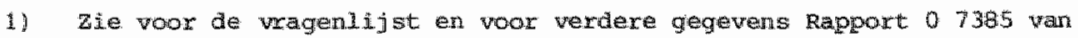
de NSS Omibus Service, januari 1979 (niet gepubliceerd).

2) Ex waren in Nedexland op dat tijdstip ca. 4. 704 duizend huishoudngen en alleenstaanden (C.B.S.). (Formule: $4.704 \times 1000 \times 196$ woor hartinfarctpati enten, analoog voor de andexén.

3) Gegevens van de Continue Morbiditeltsregistratie Pelistations over het (vermoeden op) hartinfarch in 1978 wijzen echtex op een vergelijkbaar voorkomen wan 0,3 per 100 inwoners.

4) Gegevens van de afdeling Gezondheldsstatistieken op bas 1 s wan eren detallering van de Diagnosestatistiek ziekenhuizen.

5) Euchhorn (1962) toonde aar, dat personen die ten onrechte dachteri een hartinfarct te hebben, meex leken op "echte" hartinfaretpatienten. dan personen die ten onreohte achten, geen hartinfarct te hebben gehed. Ir het gewal van de hartinfarctpatienten zou onderrapportage op grond daarvan in dit onderzoek tot meer vertekening hebben gele: dan de overrapportage ru.

6) Drie respondenten werden later vervangen door andere ondat zij niet an de gestelde eisen bleken te voldoen. De gegevens in tabel 4.4. hebben betrekking op de 75 uitelndelijk bij het onderzoek betrokken respondenten. Ir bijlage 1 zijn de patientengroepen ap eventuele werschildem in andere pexsoomskenmerken (n1. opleiding, burgexlijke staat, umbanisatiegraad van hw woongemente en verzekeringsvorn onderzocht.

7) De vragenlijst voor artsen werd am de respondent getoond. Hem/haar werd gevraaga:

"zow U er bezwar tegen hebben als ik ook Uw huisarts/specialist enkeLe wagen zou stellen? Dit is het lijstje van vragen dat ik hem wilde voorleggen. Het gat er vooral on, wat medische infomatic over UW aandoening te weten te komen."

en werwolgens verzocht zijn toesteming hlervoor schriftelijk te geven zodat de arts ervan op de hoogte kon worden gebracly. Het verzamelerd en verwerken van deze gegevens wera oevigens uitsluttend door de onderzokster zelf verricht.

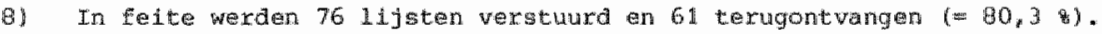
Drie ervan hadden echter betreking op respondenten die latar niet dn

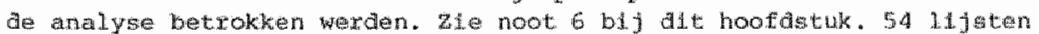
werden zonder rappel terugontwangen. Ler rappelbriaf had da ovexige zeven zntwoorden tot gevolg.

9) zie roorwoord. 
Hoofdstuk 5: Samenvatting

Dit deel behandelde de probleemsteling en de onderzoekbaarheid ervan. Wij willen hier de belangrijkste stappen die op de weg van theorie mar onderzoeksopzet zijn gezet samenvattend herhalen.

Het onderzoek richt zich op het geheel van attituden, opvatingen en gearagsintenties dat met medische consumptie te maken heeft. Dit wordt kortweg "consumptiegenelgaheia" genoem. Consumptiegeneigdheid is een van de (minder belangrijke) factoren die de medische consumptle beInvloeden. Wij interesseren ons ervoor, omat die invloed in de toekomst vermoedelijk verder toeneemt en omdat men die genelgaheid tot het raadplegen van de arts tot op zekere hoogte kan belnvloeden.

wij vragen ons af, of de consumptiegeneigoheid verschilt, afhankelijk van de ard van de andoening, die de anlelding tot het consult vormt. Voorts willen wij weten, in welke mate de consumptiegeneigdheid onder bepalde condities tot medische consumptie leidt. De derde vraag, die wij ons stellen betreft ae invloed van primalre sociale relaties - "lekenadviseurs" op liemands consumptiegeneigdheid en (ten vierde) op zijn feitelijke medische consumptie.

Ter beantwoording van deze vragen lijkt het aangewezen, om enkele voor ons minder interessante factoren, waarvan bekend is, dat zij het doktersbezoek beinvloeden, gelijk te schakelen. De belangrijkste factor betreft uiteraard de objectieve noodzaak, om het advies van een arts in te winnen. Bovendien spellen bepaalde persoonskenmerken daarbij - hetzij direct, hetzij.via andere verschijuselen - en rol. Van ouderen, vrouwen en sociaal economisch zwakkeren is bekend, dat zij hun arts in overigens vergelijkbare omstandigheden vaker radaplegen dan jongeren, mannen en mensen uit hogere milieus.

Wij hebben nogal wat woorden gewijd aan de operationalisering van de objectieve noodzaak voor medische consumptie (paragraaf 3.1. en paragraaf 4.2.3.1. Daarbij zijn criteria opgesomd, warmee men aandoeningen kan indelen naar de hoeveelheld consumptienoodzaak, die die aandoeningen vermoedelijk impliceren. op grond daarvan hebben wij uiteindelijk besloten, om respondenten in het onderzoek te betrekken, warvan bekend is dat $z i j$ 
alabet of psoriasispatient zijn of dat zij een hartinfarct hebben gehad. De overwegingen daarbij laten zich in twee punten samenvatten.

In de eerste plats gat het om objectief vaststelbare, duidelijk te diagnostiseren en relatief vak voorkomende ziekten. (In paragraaf 4.2.1. plaatsten wij hierbij ten anzien van het hartinfarct een kanttekening). Alle drie de aandoeningen kunmen aanleiding geven tot objectieve consumptienoodzak.

In de tweede plats verschillen zij echter onderling in consumptienoodzak en wel op grond van de volgende criteria (schema 5.1.$)$.

Schera 5.1. Volgorde van de mete waarin bepalde criteria op de aandoeningen van toepassing worden geacht 1 )

criteria

(zie paragraaf 3.2.)

uxgentiegrad: levensbedrefging, pifn, beleminering

$\begin{array}{lll}\text { AI } & \text { S } & P \\ 1 & 2 & 3 \\ 1 & 2 & 3\end{array}$

baat bilj medische behandelling

(afgezden van voorgeschreven

controle-consulten)

1) 1 = het meest van toepassing

2 tussenpositle

3 = het minst van toepassing

Deze indeling - gebaseerd op hetgeen daarvoor in de literatuur wordt vermeld - ligt ten gronaslag aan ons uitgangspunt, dat de consumptienoodzaak wan hartinfarctpatienten doorgaans, en afgezien van voorgeschreven controle-consulten, groter is dan due van de andere twee categorieén; en dat de consumptienoodzak van diabetici groter is dan die van psoriasispatienten. Dit uitgangspunt doet uiterard onvoldoende recht an mogelijke varlatlea binnen elk van de drie patientencategorieên. Blj de selectle van patiënt-respondènten moest daarmee rekening worden gehouden.

Het besluit om chronische patienten in het onderzoek te betrekken deed de vraag rijzen, in welke mate hierdoor de oorspronkelijke probleemsteling behouder kon blijven. Hebben chronisch patienten niet een wezenlijk andere consumptiegenelgdheld dan ge- 
zonde mensen? Betekent medische comsumptie voor hen niet iets geheel anders dar voor anderen? En tenslotte: hebber lekemadviseurs van chronische patienten niet essentieel andere verwachtingen dan lekenadviseurs van gezonden?

Paragnaf 3.2 . belichtte deze vragen tegen de achtergrond van enkele theorieën over patiëntenrolgedrag. Voor zover daarult duidelijke conclusies konden worden getrokken, gaven deze geen aanleiding de oorspronkelijke probleenstelling te herzien. zij gaven wel anleiding, om bij de ulteindelijke selectie van respondenten in het bijzonder rekening te houden met een drietal aandachtspunten.

Hoofdstuk 4 ging daarop als volgt in.

1. De respondenten zijn al langere tija hartinfarct-, tesp. suiker- of psoriasispatient; dit heeft hen "de kans gegegeven" om de patiëntenrol te vervangen door de rol van gehandicapte of chronisch zieke.

2. De invloed van genoemde persoonskenmerken (leeftijd, geslacht en social economiscine status) werd zoveel mogelijk geëlimineerd of kan als variabele in de analyse worden betrokken.

3. Bij de selectie van patiënt-respondenten moest - zoals gezegd - rekening worden gehouden met mogelijke variaties binnen de patiëntencategariën . Om zoveel mogelijk te voorkomen, dat er bij bepaalde patiënten geen consumptienoodzaak zow bestaan, kozen wij binnen elke groep de meest ernstige patiënten voor nader onderzoek.

Bovendien besteedde hoofdstuk 4 aandacht aan de gevolgde methode voor de opsporing van patiënten, nl, via zelfrapportage van a-select gekozen personen over hun (eventuele) aandoeningen. Het hoofdstuk eindigde met de operationaliseringen van het "lekennetwerk" en van het "professionele systeem". In het onderzoek zijn naast driemaal 25 patient-respondenten ook 111 lekenadvilseurs en 58 artsen betrokken. 
DE E I I I

$D E G E N E I G D H E I D A T O T$ T

G E R U I K VAN

$M E$ D I S C H E VOO OR Z I E N I N G E N 


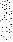


Hoofdstuk 6. Consumptiegeneigaheld nader bezien

\subsection{Inlelaing}

In het vorige deel werd in nogal algemene termen over consumptiegeneigaheld gesproken. Daarbij werd ultgegaan van de definitie, die Cassee (Cassee, 1973, p. 46) van dit begrip gaf, n1.: "Konsumptiegeneigdheid is het komplex van houdingen dat het individu in meerdere of mindere mate voorbeschikt tot medische konsumptie ${ }^{*}$.

Met deze definitie zien wij ons nu voor een tweeledige opgave gestela. In de eerste plaats moeten wij consumptiegeneigdheid als "complex van houdingen" operationalisecen en het daartoe in een aantal onderzoekbare componenten ontleder. In de tweede plaats moeten wij: dan de predictieve waarde van lde op deze wijze geoperationaliseerde) consumptiegeneigdheid onderzoeken, om liets te kunmen zeggen over de "mate warin deze het individu voorbeschikt tot medische consumptie". Bij het vervullen van deze opgave zullen wij het begrip plaatsen tegen de achtergrond van social psychologische theorieen over attituden en gedragsintenties.

Ovex het attitudebegrip bestaat echter geen eensgezindheid: "it is characterized by an embarrassing degree of ambigulty and confusion" (Fishbein en Ajzen, 1975, p. 1). De theorieen erover staan in de afgelopen jaren weer sterk in de belangsteling, omdat traditionele opvattingen over attituden en over de relatie tussen attituden en gedrag kritiek hebben ondervonden. Deze kritiek komt deels overeen met de kritische kanttekeningen van Rosenstock (1974) bij de "Health-Belief-Model"-benadering (zie hoofdstuk 21.

De ultgangspunten in onze studle zijn voornamelijk gebaseerd op het werk van Flshbein (1967, Fishbein en Ajzen, 1975). Daarin wordt niet alleen andacht besteed aan theoretische achtergronden van het attitudebegrlp, maax teven aan de mogelijkheden voor attitudeneting.

\subsection{Het attitudebegrip}

De theorie van Fishbein gat ervan uit dat attituden ("attltudes"), opvattingen ("bellefs") en gedragsintentles 
("behaviarol intentions") het gedrag afzonderlijk beinvioeden. opvattingen ten anzien van bet attitude-object ontstaan door ewaringen met dat object en met gedrag zelf. Attituden zijn evaluaties van bepalde opvattingen, mar kunnen het gedrag los daarwan bejnwloeden. Iemand kan bijwonrbeeld vinden (opvatting), dat gastarbeiders ljverig zijn. ondanks dat is het mogeiljk, dat hil gastaxbeiders over het algemeen niet waardeert (attitude) en hen daardoor afstandelijk tegemoet treedt. In gedragsuntenties, tenslotte, worden volgens Fishbein normen weerspiegeld, die het individu in kwestie er ten aanzien van $z$ ijn eigen wenselijk gedrag op nahoudt, en die mensen in de omgeving van dat irdividu darover uiten. $2 i j$ hebben met attitudes weinig te maken, worden er hooguit mede door gevorma, maar zij beInvloeden het gedrag direct. On bij het voorbeeld te blijven: de betrokkene pleegt tegenover gastarbelders wel beleefd te zijn.

Hierbij aansluitend kunnen wij consumptiegenelgaheid opvatten als geheel van opvattingen, attituden en gedragsintenties dat met medische consumptie te maken heeft. Daardoor valt het concept utteen in een aantal componenten, warvoor per component de relatie met medische consumptie moet worden nagegaan. Wij komen hiermee op een belangrijk kritiekpunt ten aanzien wan traditionele attitudetheorleën.

Volgens die kritiek wordt de relatie tussen attitude en gedrag veelal te nauw verondersteld (Ehrlich, 1969). Een attitude is nlet meer dan een predispositie. Het gedrag wordt daarnaast ook door andere factoren beinvloed, die de rol van de attitude eventueel kunnen neutraliseren. Daardoor kan het gedrag wel eens een amder zijn, dan men op grond van de attitude ten aanzien van het gedrag (sobject) zou verwachten. Bovendien is er sprake van eon wisselwerking tussen attitude en gedrag: bepaald gedrag kan verandering van attituden tot gevolg hebben.

Voor onderzoek nar determinanten van medische consumptie betekent dit uiteraard niets nieuws. Andere factoren, met name de aandoening of $\mathrm{klacht}$ in kwestie (consumptienoodzaak) en bepalde persoonskenmerken, spelen blj het onderzoek zelfs een grotere rol als gedragsvoorspellers, dan de opvattingen en attituden die met medische consumptie te maken hebben. De interpretatieverruiming van het ziektebegrip en daamee van de noad- 
zaak medische hulp in te roepen, heeft er echter toe geleld, dat geneigdheidscomponenten een relatief grotere rol aj gn gaan spelen bij.medische consumptie (Lamberts, 1974/1975, van der velden, 1976, Huygen, 19781. Juist daaxom rioht ons onderzoek zich immers op consumptiegeneigdheld. De vraag naar de predictiewaarde van consumptiegeneigdheid als voorspeller van medische consumptie komt in het volgende hoofdstuk aan de orde.

Wij gaan nu over tot het operationaliseren van het begrip consumptiegeneigdheld. In ons onderzoek hebben wij geprobeerd bij de opvattingen en aanbevelingen van fishbein en Ajzen en bij de door Wilke en Kok (1978) opgesomde suggesties ontrent het operationaliseren van opvattingen, attituden en gedragsintenties aan te siluiten.

Tegelijk zij er echter op gewezen, dat wij ook niet meer dan dat hebben geprobeerd. Wij willen met name geen veronderstellingen cormuleren omtrent de onderlinge relaties tussen te onderscheiden componenten van consumptiegeneigdheld. Fishbein en Ajzen spreken zich wel wit over relaties tussen opvattingen, attituden, gedragsintenties en gedrag, die zij in causale modellen samenvatten. Wij zijn echter van mening dat het niet mogelijks is om componenten van consumptiegeneigdheid zodanig te operationaliseren, dat zij niets meer en niets minder indiceren, dan specifieke opvattingen, attituden of gedragsintenties. Vooral op het terrein van iemands gezondheid zijn deze componenten onderling zo nauw verweven, dat zij al moeilijk onathankelijk van elkaar te onderzoeken zijn (Bergsma, 1977). Voor veronderstelilingen omtrent de precieze aard van de samenhang ertussen ontbreekt naar onze mening elke grond. Dit blijkt bijvoorbeeld wit de verschlllende replicaties van Suchman's ondex"zoek (Geertsen e.a., 1975, Ben-Sira, 1977. Farge, 1978). Daarin komt naar voren, dat de door suchman veronderstelde samenhang tussen gedragswoorspellers onderling niet altijd kon worder aangetoond, mar dat de variabelen tezamen de medische consumptie wel redelijk voorspelden. 


\subsection{Operationaliseringen van consumptiegeneigaheid}

6.3.1. Indelding

Wh waten consunptiegeneigaheid nu dus op als het geheel van opvattingen, attituden en gedragsintenties dat met medische consumptie te maken heeft. Deze definitie verwijst naar een object ten arizien warvan men bepalde opwattingen, attituden en gedragsimtenties heeft. Daarbij is het begrip "medische consumptie" als object nogal rulm van imhoud en tenminste voor de respondent te abstract, om bij hem een zinnige voorstelling op te roeper.

In onze probleemstelling gaat het om de mate warin lemand genelgd is, om hulp van professionele werkers in te roepen voor bepalide gepercipleerde ziekteverschijnselen. Daaruit valt af te lelden, dat wij bij consumptiegeneigdheid met twee objecten te maken hebben, nl. met

1. het professionele systeem, orwel: de medische zorg en met

2. zitekteverschijnselen warvoor men professionele hulp zou insoepen, ofwel: de wijze warop de betrokkene zijn of har zlekte beleeft.

Welke verschijnselen worden in ons onderzoek opgevat als attitudeobjecten? Als een van de bezwaren van attitudemeting wordt veelal naar voren gebracht, dat de onderzochte personen op het moment van onderzaek onvoldoende eigen ervaring met het attitudeobject hebben (Regan en Fazio, 1977) of dat de attituden op dat moment nog onvolledig gevormd zijin (Ehrlich, 1969). om aan dit bezwar zoveel mogelijk tegemoet te komen hebben wij. zoals eerder opgemerkt, het onderzoek op personen gericht, die al langere tija bepalde aandoeningen hebben. Men mag aannemen, dat deze mensen (1) in verband met de medische zorg al enige ervaring hebben opgedaan, doordat zij ten minste een tijd lang regelmatig een of meer artsen radpleegden en ( 2 ) met het ondervinden van ziekteverschijnselen min of meer vertrouwd zijn, doordat $\mathrm{z}^{\mathrm{j} j}$ een chronische aandoening hebben. Wij zullen de attituden dan ook opexationaliseren in termen van de "eigen arts" en de "elgen aandoening". 
onze onderzoeksopzet impliceert daardoor echter tegelijk. dat moet worden nagegaan - voorzover binnen het beschikbare materiaal mogelijk - in welke mace de ard van de chronische andoening de opvattingen en attituden ten aamien van de medische zorg en ten aanzien van ziekte belnvloedt of zelf bepalt. Zoals lierna zal blijken, werd de consumptiegeneiguheid gelndiceera door middel van vijf afzonderlijke schalwaaraen. Nu is het niet uitgesloten, dat bijvoarbeeld bepalde deelopvattingen over de medische zorg alleen blj hartinfarctpatiënten samenhangen met bepalde andere deelopvattingen erover, terwijl dat bij diabetici of psoriasispatiënten niet het geval is. Daarbij kan de ervaring van de patiënten met bepalde vormen van zorg een rol spelen. Bij de operationalisering van componenten van consumptiegeneigaheid werd hiermee zoveel mogelijk rekening gehouder.

In aansluiting op de opvattingen van Fishbein en Ajzen (1975) werd het heteragene begrip consumptiegeneigdheid uiteengelegd in componenten en als volgt geoperationaliseerd:

1. opvattingen over de medische zorg

2. attituden ten aanzien van de eigen arts lals de belangrijkste representant van professionele gezondheidswerkers)

3. opvattingen over ziekte

4. attituder ten aanzien van de eigen aandoening, kortweg ziektebeleving genaremd

5. gedragsintenties met betrekking tot het raadplegen van de eigen arts (zie opmerking bij 2.).

Gezien het algemene, weinig specifieke karakter van het begrip consumptiegeneigdheid, gaat het ons om vrij globale opvatingen, attitudes en gedragsintenties, niet on dimensies daarbinnen. Daarbij hebben - zoals hierondex zal blijken - de opwattingen (1 en 3) betrekklng op de medische zorg en op ziekte in het algemeen. De evaluatieve componenten ( 2 en 4) siluten eerder aan bij persoonlijke ervaringen van de respondenten.

\subsubsection{Opvattingen over de medische zorg}

In navolging van Cassee werd de respondenten een aantal uitspraken voorgelegd, waarop zij konden reageren met antwoor- 
den varlerend wan at 1 beslist $20^{\text {"a }}$ tot "dat is beslist niet zo" In zes categorieen, d.w.z. zonder een "newtrale antwooramogelijkheld. Blf de ultspraken ging het over opvattingen over ziekte en over gedrag of adviezen van artsen (bijlage 2). De proefenquetes er de audiovisuele test van de vragenlijst (zie hoofdstuk 4.6) gaven aanleiding, de oorspronkelijke formulering wan enkele uitspraken te wijzigen en bepalde uitspraken door andere te vervangen. Van een vergelijking met de resultaten van Cassee is daaron afgezien, mede omat deze noch de onze betrekking hebben op een voor Nederland representatieve steekproef.

In welke mate worden de opvattingen over genoemde zaken nu beinvloedt of zelfs bepaald door het felt, dat lemand een hartinfarct gehad heeft, diabeet of fsoriasispatiënt is?

Om hierin inzlcht te krijgen zou men de deelopvattingen per patiantencategorle aan een factoranalyse willen onderwerpen en de drie factarstructuren willen vergelijken. Duidelijke verschilien dadrussen zouden dan op een invloed van de aandoening op de opvattingen kunnen wijzen. Deze werkwijze kan echter bij een relatief groot aantal ltems en een klein aantal waarnemingen beter niet worden gevolgd. Aangezien onze patiëntencategorieên slechts 25 respondenten bevatten, hebben wij een andere oplossing toegepast.

Wij indiceren het wel of niet hebben van een hartaandoening, van diabetes of psoriasis met behulp van drle dumyvariabelen. Vervolgens werd met de $20^{\text {I }}$ opvattingen over medische zorg en over ziekte driemaal een factoranalyse uitgevoerd, waarbij telkens een "aandoeningsdumy" als variabele werd meegenomen. Dit geschiedde in de veronderstelling, dat een duidelijke invloed van een aandoening op de opvattinger in de factorstructuur tot utudruking zou komen, doordat de dummyvardabele tezamen met een of meer opvattingen esu factor zou vormen, Als de dumit darentegen Een afzonderlijke factor zou vormen, wonder dat een of meer opvattingen op deze factor een hoge lading krijgen, dan is de inhow van de opvattingen warschijnlijk relatief onafhankelijk van de arle aandoeningen. Daarnaast gaf deze werkwijze toch de mogelijkheid, om de drie factoranalyses onderling te vergelijken. aok bij deze ver- 
gelijking zou immers enig inzicht verkregen kunnen worden in de rol die de aandoening speelt bij de verschlllende opvattingen van de patienten. Bij de interpretatie van de dirie factoranalyses stonden derhalve de volgende twee vragen voorop:

1. op welke factor heeft de "aandoening sdumy" een hoge lading?

2. kunnen de factorstructuren van de arie analyses op vergelijkbare wijze geinterpreteend worden?

Wij vatten de resultaten als volgt samen (zie ook bijlage 2).

In twee van de drie gevallen vormde de "aandoentngsvariabele" (dummyl gen afzonderlijke factor: geen enkele deelopvatting verkreeg op dere factor een hoge lading. In het derde geval had het item "het gebed is het beste geneesmidael dat denkbaar is" tezamen met de dumy betreffende het hartinfarot een hoge lading op een factor. De factorstructuur verschilde werder echter niet wezenlijk van de andere twee, zodat ons inziens de volgende conclusie getrokken mag worden. De factorstructuur binnen de 75 warnemingen mordt niet veroorzaakt door een clustering binnen bepalde patiëntengroepen, ofwel: de opvattingen $z i j n$ als relatief onafhankelijk van bepaalde andoeningen te beschouwer.

Wij gaan nu op de inhoud van deze opvattingen in en beginnen met opvattingen over medische zorg. De opvattingen over zlekte komen in de volgende paragraaf verder aan de orde.

De vragenbatterij bevat zes items die betrekking hebben op gedragingen van artsen tegenover te behandelen patienten. Tabel 6.1. geeft weer hoeveel respondenten op deze uitspraken reageerden met "dat is (beslist) zo". Tezamen geven de antwoorden een globaal inzicht in de mate van vertrouwen, dat men in de medische zorg heert.

Wij gingen na of deze ultspraken gezamenlijk deze dumensie inderdaad weerspiegelen. Met ultzondering van de ultspraak "artsen weten ook niet altijd wat goed voor je is" zijn de items wolgens de Likert-methode (Fishbein en Ajen, 1975 , p. 72) schalbaar2) De schaal loopt van "veel vertrouwen" (1age score) naar "weinig vertrouwen" (hoge score) in de medische zorg. 
Tabe 1.6.1. Mate van instering mot opvateingen ovex gedxagingen van artsen tegenover te behandelen patianten nar patientencategorie (atintal antwoorden "dat is (beslist) zo")

$\begin{array}{ccc}\begin{array}{c}\mathrm{R} \\ (\mathrm{W}=25)\end{array} & \begin{array}{c}\mathrm{S} \\ (\mathrm{N}=25)\end{array} & \begin{array}{c}\mathrm{P} \\ (\mathrm{N}=25)\end{array} \\ 7 & 2 & 1 \\ 5 & 12 & 8 \\ 5 & 4 & 4 \\ 8 & 9 & 7 \\ 10 & 15 & 7 \\ 15 & 10 & 6\end{array}$

\subsubsection{Attituden ten aanzien van de elgen arts}

zoals in hoofdstuk 4 ulteengezet, wordt door 44 patiëntrespondenten eer specialist en door 30 patiënt-respondenten de huisarts als de "eigen arts" beschouwd. On de attituden ten aanzien van de eigen arts te operationaliseren, 15 in de eerste plaats gevraagd in welke mate men tevreden is met de aandoening in kwestle. Tabel 6.2. geeft de mate van tewredenheid van de drie patidentengroepen weer.

Tabel 6.2. Tevredenhelid met de eligen arts nar patientencategorie (eenweg variantie analyse)

\begin{tabular}{|c|c|c|c|c|}
\hline & $\begin{array}{l}\text { hart- } \\
\text { patiërnten }\end{array}$ & $\begin{array}{l}\text { suiker- } \\
\text { patiënten }\end{array}$ & $\begin{array}{l}\text { psoriasis-13 } \\
\text { patienter }\end{array}$ & totaal \\
\hline $\begin{array}{l}\text { buitengewoon } \\
\text { tevredien }(1)\end{array}$ & 10 & 8 & 4 & 22 \\
\hline $\begin{array}{l}\text { zeex } \\
\text { tevreden (2) }\end{array}$ & 9 & 6 & 7 & 22 \\
\hline tewreden (3) & 5 & 6 & 9 & 20 \\
\hline $\begin{array}{l}\text { tamelijk } \\
\text { trveden (A) }\end{array}$ & 1. & 2 & $\mathbb{1}$ & 4 \\
\hline $\begin{array}{l}\text { niet wo } \\
\text { tevreden (5) }\end{array}$ & - & 3 & 3 & 6 \\
\hline gemiade la & 4.88 & $\begin{array}{l}2.67 \\
2.98\end{array}$ & $S^{2.44}$ & 2.29 \\
\hline
\end{tabular}

1) Één responcent heeft geen arts genoend 
De verschilien tussen de patiëntencategorieen zijn miet significant. Er is wel een aanwijzing voor het felt, dat hartinfarcteatienten lets positiever tegenover hun arts stam, dan de andere twee categorieèn. Dit is begrijpelijk als men bedenkt, dat vele hartinfarctpatienten het ingrijpen van artsen naar aanleiding van het infarct warschijniljk als levensredaing ervaren hebben.

Bij de beoordeling van dit soort tevredenheidrragen moet men wel bedenken, dat daamee niet alleen eigenschappen van het object - in ait geval wan de arts - maar ook ejgenschappen van het subject - de respondent - geregistreerd worden (Pommex en van Praag, 1978). In de antwoorden komt, met andere woorden, een belangrijk deel van lemands persoonlijkheid tot ultarukking. Daarom is de attitude ten aanzien van de eigen arts ook nog op andere wigze gemeten.

De respondenten konden op een aantal uitspraken over eventueel bij hun arts aamezige eigenschappen reageren met "dat is beslist zo" aan de ene kant tot "dat is beslist niet zo" aan de andere kant (zespunts-schaal). De uitspraken zijn voor het merendeel letterlijk overgenomen van cassee (1973), maar wij wilden niet zoals hij het feitelijk gedrag van de arts, maar het door de respondent gepercipieerde en geëvalueerde gedrag meten. In tabel 6.3. zijn de uitspraken en resultaten weergegeven.

In welke mate wordt nu de samenhang tussen deze antwoorden, het gehele antwoordpatroon, door de aard van de aandoening bepald? Voor de beantwoording van deze vraag zijn wij op dezelfde wijze tewerk gegaan als bij de operationalisering van opvattingen over medische zorg. Kortheidshalve wordt hiervoor verwezen nax de vorige paragratif $(6.3 .2$.$) .$

Drie factoranalyses van de items met telkens een aandoening als dumy erbij betrokken, rechtvatedigen de conclusie, dat de arar van de attitude ten anzien van de eigen arts niet afhankelijk is van het feit, of iemand hatpatient, diabeet of psoriasispatient is (zie bijlage 3). De drie factarstructuren zijn goed vergelijkbat. Daarbij vormt de dumm-warlabele telkens een aparte factor, zonder dat andere items darop een hoge lading krijgen. De factorstructuur wordt dus niet veroor- 
Tabel 6.3. Mate warn irsteming met u.tspraken betreffende de eigen arts naar patientencategorie (aantal antwoorden "dat is (besliat) zo")

\begin{tabular}{|c|c|c|c|}
\hline & $(x=25)$ & $\mathbb{S}$ & $\begin{array}{c}P \\
(N=24)\end{array}$ \\
\hline Mign (huil arts ars & & & \\
\hline 1. je rogal onzekex in 21 in optreder & 10 & 1 & 3 \\
\hline $\begin{array}{l}\text { 2. Sitad erop, dat je precies doet } \\
\text { wat his zegt }\end{array}$ & 15 & 15 & 11 \\
\hline $\begin{array}{l}\text { 3. vertelt me precles ho ernatig } \\
\text { het ig: }\end{array}$ & 17 & 13 & 12 \\
\hline $\begin{array}{l}\text { 4. stelt je op je genak alls je met } \\
\text { hem praat }\end{array}$ & 18 & 18 & 19 \\
\hline 5. Lis nogál zakelijk & 12 & 6 & 4 \\
\hline $\begin{array}{l}\text { 6. schrijft je naukeuxig voor wat } \\
\text { je moet doen }\end{array}$ & 18 & 2.6 & 20 \\
\hline $\begin{array}{l}\text { 7. praat met me over andere dingen } \\
\text { dan over milin ziekte al leen }\end{array}$ & 7 & 9 & 10 \\
\hline $\begin{array}{l}\text { 6. Legt me ult waarom hij lets op } \\
\text { een bepalde manier doet }\end{array}$ & 15 & 9 & 12 \\
\hline 9. behandelt me als nummer & 0 & 2 & 0 \\
\hline $\begin{array}{l}\text { 10. praat met } \\
\text { medische problemen }\end{array}$ & 7 & 9 & 10 \\
\hline $\begin{array}{l}\text { 11. heeft welnig tija voom me als } \\
\text { ik hem raadpleeg }\end{array}$ & 1 & 4 & 0 \\
\hline $\begin{array}{l}\text { 12. is bereid om naar je moeilljk- } \\
\text { heden te lulsteren }\end{array}$ & 16 & 18 & 17 \\
\hline 1) Exn respondent heeft geen (huis)arts & & & \\
\hline
\end{tabular}

Voox de uiteindelijke operationaliseringen van de attitude ten arizien wan de eigen arts werden alle items tezamen op schalbarhedd getoetst. De uitspraken "mijn arts staat erop. dat je precles doet wat hij zegt" en "... schrijft nauweurig voor .." vormen een aparte dimensie, die niet significant samenhangt met een positieve c.q. negatieve attitude ten a anzhen van de arts. Het eerste 1 tem berelkt evenmin een bevredigend significantleniveau, reden watrom wij ook dit op dit punt buiten beschouwing lieten. Wij komen daarop in hoofdstuk 13 nog terug. De definitleve schal bevat aus negen items en logt van een positieve naar een negatieve attitude ten aanzien van de elgen arts (Hoyt-coëficięnt: .81). 


\subsubsection{Opvattingen over zliekte}

In paragraar 6.3.2. werd al vermela, dat de respondenten hum opvattingen over zlekte kenbaar konden maken door op bepalde uitspraken dienaangaande te reageren met "dat is beslist zo" of "dat 1 "s beslist niet zo" (zespuntsschaal). vonrts werd in die paragraaf ingegaan op de eventuele inviloed van de aandoening op het antwoordpatroon ten aanzien van opvattingen over de medische zorg en ovex aiekte tezamen. Van een dergelijke invloed was nauwelijks sprake. wij gaan in deze paragraf verder in op de inhoud van de opvattingen over ziekte.

Tabel 6.4. geeft weer, in welke nate de drie patientencategorieen instemen met genoemile uitspraken.

Tabe1 6.4. Mate wan insteming met bepallde opvattingen over ziakte nar patiêntencategorie (aantal antwoorden "dat ilg (beslits) wo")

1. Bifina alke ziekte heeft een

\begin{tabular}{ccc}
$H$ & $S$ & $p$ \\
$(N=25)$ & $(\mathbb{N}=25)$ & $(\mathbb{N}=25)$ \\
\hline
\end{tabular}
psychische achtergrond

2. De diepere oorzaak van veel ziekten zitt in de manier van leven

3. Ziekte ontstaat in de meeste gevallen door spaniningen

4. De naturur geneest zichzelf

5. Honing is een geneesmidalel voor vele kwalen

6. Je kunt betex te wein gingenmiddelen innemen dan teveel

7. Verstandig leven vookont weel ziekten

8. Het beste geneesmidal is een rein en opgewekt leven

9. In ziekte openbaart zich de strije tuissen gaed en kraad in de mens

10. Veel ziekten zijn een gevolg van cen losbandilg leven

11. Veel ziekten ontstan ondat de mens te ver van de maturur afleeft

12. Je kunt weinig doen aan je eigen giezondhe lastaestand

13. Het gebed is het beste geneesmiadel. dat denkbaar is

14. zlekte is een straf op de zonde
10

9

7

5

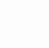

10

9

7

20

18

17

13

7

3

2

6

6

5

1

$$
6
$$

5

5

5

6

19

15

14

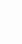

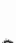

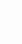

3

3

2

5

3

6

1 
De ultpraken werspiegelen over het algemeen vanult medisch oogpunt nogal onprofessionele opvattingen over ziekte en genezing : Somugen ervan zijn moralistisch-religieus van aard $(2,7,6,9,10,13$ en 14), in anderen kont een affiniteit met natuurgeneeswijzen tot uitarukking $(4,5$ en 11$)$ en in de overigen een zekere afkeer van strikt medische benaderingswijzen (1, 3, 6 en 12). Wy hebben onderzocht of deze items tezamen tot 6 schal verwerkt konden worden, die deze weinig professionele zlekteopvattingen zou kunnen indiceren. De correlaties tussen de antwoorden op de items 6, 12 en 14 en de schalwarar berelkten niet het vereiste significantieniveau. De uitspraken 6 en 12 wijzen inderdaad minder op onprofessionele opvattingen dan de overtgen; $z i j$ zijn eerder rationeel van ard en berusten wellicht op "common-sense"-inzlchten. De opvatting dat ziekte een straf op de zorde is, is mogelijk te uitgesproken - zij wordt dan ook door weinig mensen gedeeld - om met de schalwarde samen te hangen. De overige elf items vormen een schaal, die loopt van "onprofesstonele" naar "professionele" ziekteopvattingen (Hoyt-coëfficiënt: . 77).

\subsubsection{Attituden ten aanzien van de ziekte}

In de literatuux wordt aan deze component van de geneigdheid tot medische consumptie veel aandacht besteed. Hij neent bljvoorbeeld in de benaderingen, die op zoek naar determinanten var preventief - en ziektegedrag het "Health Belief Model" hanteren een centrale plaats in. Daarbij wordt hij geoperatiomaliseera in termen van de dreiging die van de zirkte(n) uitgat, $n 1$. de gepexcipieerde watbarheld en angst voor de ziekte $(n)$ en van de gepercipleerde ernst van de aandoening (en) (Becker, 1977 ).

Hoofdstuk 3, paragraaf 3.1.2, besteedde hieraan uitgebreid aandacht. Daarin werd witeengezet, waarom wij de attitude ten arazlen van de elgen ziekte zoveel mogelijk onafhankelijk van de "objectleve gezondheidstoestand" operationaliseren. Het gat hier on de subjectieve ziektebeleving.

Wij hebben deze geneigdheldscomponent niet uitsluitend met behulp van een woorgestructureerde vragenlijst willen meten, 
maar ook getracht te achterhalen, op welke wijze elke respondent zijn of haar aandoening persoonlijk ervaart (Emans, 1978. p. 127, De Graaf, 1980). De vragenlijst bevatte daarom een groot aantal open vragen, warop de ondervragde vrij vertellend kon reageren. Aan het einde van elk gesprek werd tenslotte gevraaga, of bepaalde zaken ten onrechte niet aan de orde waren geweest, die volgens de respondent bij een onderzoek naar het leven met een bepaalde aandoening toch belangrijk zijn.

Mede met behulp van deze kwalitatieve gegevens is op subjectleve wijze door de onderzoeker per respondent een warae voor subjectieve zlektebeleving toegekend en wel op de volgende manler (zie ook bijlage 4). Voor iedere respondent, en dus per patientencategorie afzonderlijk is nagegaan ${ }^{3}$ )

1. Het aantal leefregels dat men van de dokter gekregen heeft, bijvoorbeeld of men een bepaald diëet moet volgen.

2. De hinder, die men van de aandoening ondervindt in termen van lichamelijke verschijnselen, zoals pijn.

3. De belemmering bij dagelijkse bezigheden door de andoening, bijwoorbeeld bij hulshoudelijk werk, op feestjes.

4. Het oordeel van de arts ${ }^{4}$ ) over de ernst van de aandoening.

5. Het oordeel van de enquetrice over de mate warin het aan de ondervraagde persoon te merken of te zien was, dat hij of zij een hartinfarct heeft gehad, dan wel diabeet of psoriasis-patiènt is.

Deze meer "objectieve" gegevens over de aandoening en de gevolgen ervan voor de patient, werden door de onderzoekster per geval afgewogen tegen de wijze warop de tespondent reageert lop de open vragen): In welke mate houdt de aandoening hem bezig? praat hij er in moedeloze dan wel in opgewekte bewoordingen over? Besteedt hij relatief veel of weinig andacht aan de gevolgen van zijn aandoening?

Deze werkwijze resulteerde in een waardetoekenning per respondent voor zijn of haar subjectieve zlektebeleving van relatief goed (1) tot relatief slecht (5) met de volgende verdeling per patientencategorie (tabel 6.5.). 
Tabe1 6.5. ZLektebeleving, kwaltatief bepadd, per patientencategorie (absolute antailen\}

\begin{tabular}{|c|c|c|c|c|c|}
\hline & & $\begin{array}{l}\text { horet- } \\
\text { patienten }\end{array}$ & $\begin{array}{l}\text { suikex- } \\
\text { patienten }\end{array}$ & $\begin{array}{l}\text { psoriasis- } \\
\text { patienten }\end{array}$ & allen \\
\hline relaties & (1) & 2 & 3 & 1 & 6 \\
\hline \multirow[t]{2}{*}{ goed } & (2) & 5 & 10 & 7 & 22 \\
\hline & (3) & 9 & 7 & 11 & 27 \\
\hline relatief & (4) & 7 & 3 & 6 & 16 \\
\hline \multirow[t]{2}{*}{ wecht } & (5) & 2 & 2 & - & 4 \\
\hline & & 25 & 25 & 25 & 75 \\
\hline
\end{tabular}

Deze kwalitateve en uiteraard subjectief bepalide maat werd aangevuld met gegevens, die een objectiever karakter hebben. Aan de hand van de antwoorden op enkele gesloten vragen over ziektebeleving berekenden wij per patiëntencategorie en voor alle respondenten tezamen een aantal intercorrelaties (Spearman's rho). Op grond van de verschillende correlatiepatronen is besloten naast de kwalitatieve beoordeling van ziektebeleving ook de volgende vijf variabelen bij de operationallsering te gebruiken.

- mate warin men zich zorgen makt over de aandoening

- mate warin het leven anders is dan dat van anderen door de aandoening

- mate warin men geleerd heeft met de aandoening te leven

- mate warin men zich ziek of gezond acht met de aandoending

- frequentie warmee men meer last krijgt van de aandoening ten gevolge van spanningen (zle bijlage 4).

Alle zes variabelen werden tezamen via de Llkext-methode tot een whal werwerkt (Hoyt-coëfficiënt: .74), die loopt van een relatief slechte (lage score) naar een relatief goede (hoge score) ziektebeleving.

6.3.6. Gedragsintenties met betrekking tot medische consumpte

Bif de operationalisering van gedragsintenties is ernaar gestueefd, om de te meten Intentie zo nauw mogelijk te laten aansluiten bij het gedrag, in dit geval bij het raadplegen van de dokter. Wij proberen hiermee bij ideeẻn van o.m. Liska 
(1974) aan te slutten, die adviseert, ork gedrag en intentie zoveel mogelijk ap hetzelfde niveau te meten.

Hiervoor wer een vragenbattexij ontworpen ${ }^{5)}$ met verschillende concreet omschreven situaties warin zich lichanelijke verschijnselen voordoen (vergelijke Kok, 1979, p. 39).

Voor elke situatie werd een tijdstip aamgegeven ("u hebt sinds Een week ..." "u hebt al arie dagen....") en de vraag gesteld, wat men op dat moment zou doen. De vijf antwoordmogelijkheden bestonden uit - eveneens zeer concreet omschreven - ordunal gerangschikte gedragsalternatieven, varierend van "de dokter zo snel mogelijk opbellen en on raad vragen" tot "er geen aandacht aan besteden". (Tabel 6.6. geeft de resultaten naar patiëntencategorie weer.)

Het is niet onwarschijnlijk, dat zich juist hier verschillen tussen patiëntencategorieën voorcioen. Om ait na te gaan is daram per item een uitgebreide mediaantoets uitgevoerd. Het bleek, dat ex slechts in én van de veertien situaties door de patiëntencatecorieen verschillend gehandeld zou worden (item 11 , zie tabel 6.6.). Het significantieniveau bedroeg $p \leq .05$. Het item werd in de verdere analyse gehanahadi. Wij hoopten ên dimensie te vinden die omschreven kan worden als een "sterke tegemover een geringe intentie" om in deze situaties de arts te raadplegen. Om hierin inzicht te krijgen bestudeerden wij de ongerateerde factorstructuux (zie bijlage 5). De eerste factor bond 27,6 variantie. Op deze factor laden alle items .48 of hoger. Wij besloten op grond van deze resultaten de gedragsintentie te indiceren door de somscore van de antwoorden (Hoyt-coëficiënt: .79). Een lage score op deze schaal geeft een sterke gedragsintentie aan, een hoge score een geringe gedragsintentile. 


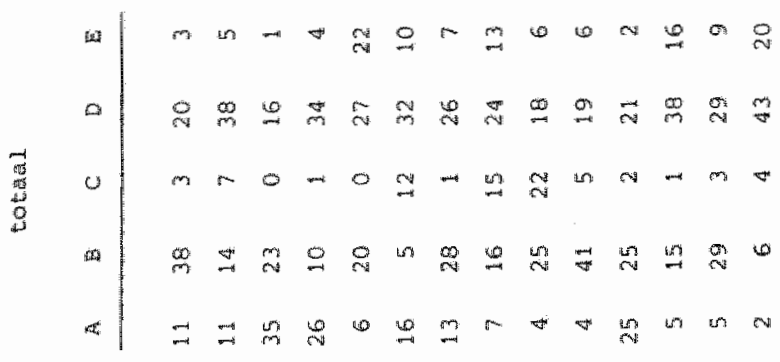

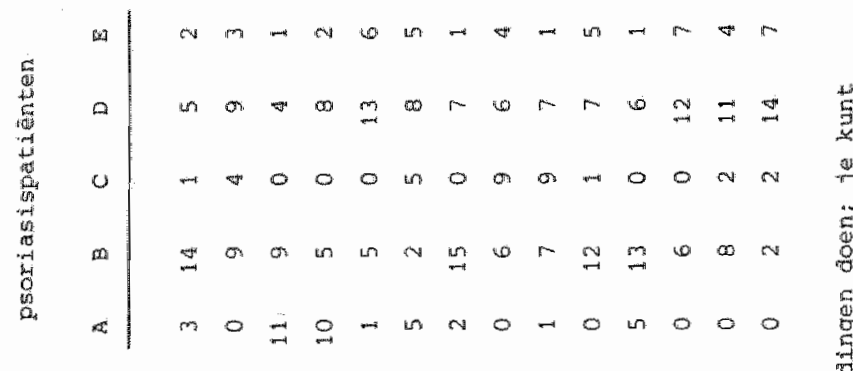

量

$\rightarrow$

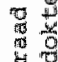

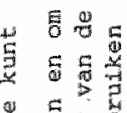

논

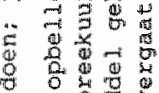

o 8

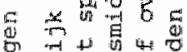

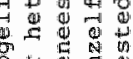

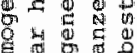

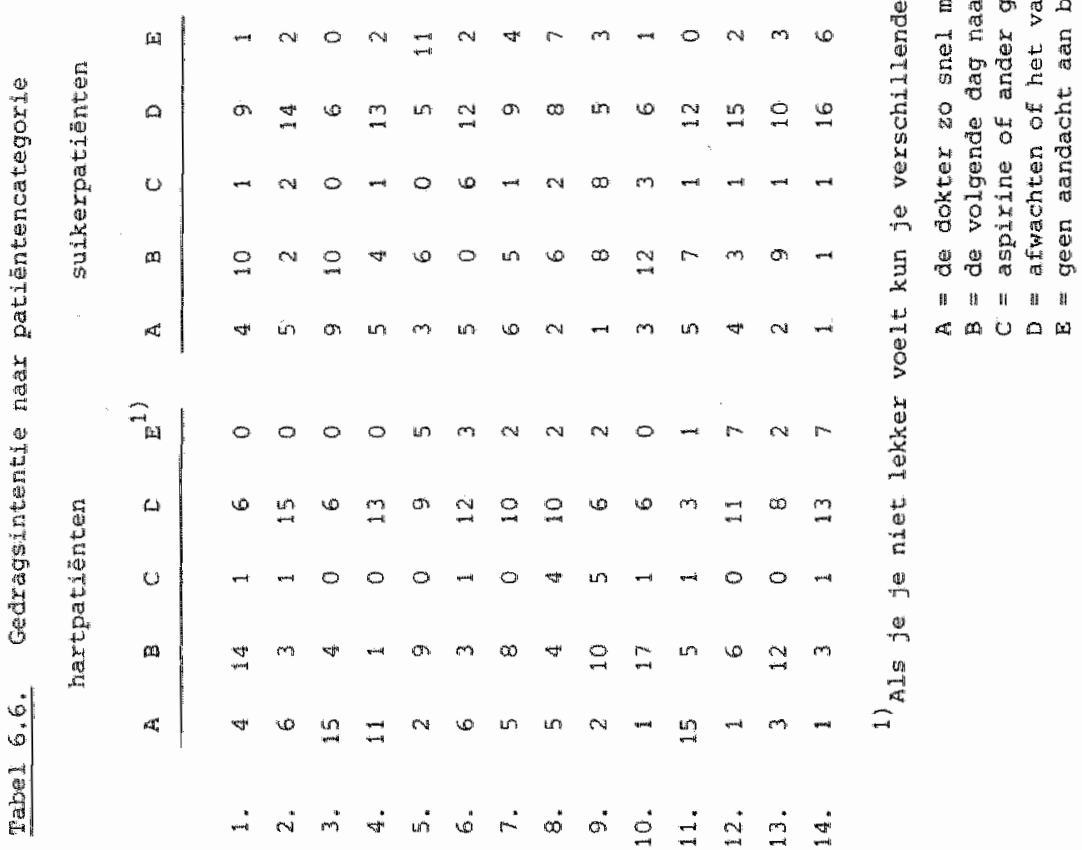




\section{Uitspraken behorende bij tabel 6.6. : gedragsintenti.e}

1. U hebt sinds een week jeukende uitslar

2. U hebt een middag lang sterke pijn in de buik

3. $\mathrm{u}$ ontdekt op een keer bloed bij de ontiasting

4. Webt ineens last van hartkloppingen

5. U hebt sinds een week gebrek aan eethust

6. U hebt op een achtend 380 koorts

7. U hebt vier dagen aaneen sterke dorst

8. U bent al dxle dagen verkouden en u hebt keelpijn

9. U hebt een day of viler lang hoofdplin

10. U hebt op een ochtend eczeem op de armen

11. U hebt op een dag ineens last van kortademigheld en benawdheld

12. U moet sinds drie dagen wakex plassen dan u normadil acht:

13. o voelt zich al een week of twee niet echt fit

14. U voelt een dag of twee pilin in de rug

\subsection{Consumptiegeneigdheid in dit onderzoek}

Wij hebben vijf variabelen geconstrueerd, die tezamen het heterogene begrip consumptiegeneigdheid moeten indiceren. Bij de operationalisering is telkens nagegaan, of de afzonderlijke variabelen (= geneigdheidscomponenten) door de aard van de aandoening van de hier ondervraagde personen beinvloed wordt. Dat was bij geen van de vijf componenten duidelijk het geval. Hiermee kunnen wij voorzichtig concluderen - voorzichtig, omdat slechts drie andoeningen in het onderzoek betrokken zijn dat de hier geoperationaliseerde geneigdheidscomponenten consumptiegeneigdheid van chronische) patiënten wn het algemeen indiceren. Tabel 6.7 . geeft een overzicht van hun ondexinge samenhang.

De correlatie tussen opvattingen over medische zorg en de attitude ten aanzien van de eigen arts ligt in de 1 ijn dex verwachting. De ontbrekende samenhang tussen de opwattingen over zlekte en ziektebeleving valt op. Vanuit theoretisch oogpunt zou men immers kumnen verwachten, dat opvattingen over ziekte in het algemeen samemhangen met attituden ten aanzien van eigen 
ziekte. Hiex blijkt dat de eigen ziekte en haar ervaren gevolgen rellatief los staan van het feit, of de patient over ziekte in het algemeen ex meer professionele opvattingen op nahoudt of niet. Opvallend tenslotte is ook het feit, dat een relatief slechte ziektebelewing samenhangt met negatieve attituden ten aarizen van de arts en daarmee ook met weinig vertrouwen in de medische zorg. Dit is een aanwijzing voor de eerder genoende afstand tussen patidint en professioneel systeem.

De correlatiematrix makt over het algemeen echter duidelijk, dat de onderscheiden genelgdheidscomponenten relatief onafhankelijk van elkaar zijn. Dit is een belangrijke uitkonst. Hij steunt ons in het voornemen, af te zien van het construeren wan Ën index voor consumptiegeneigdheid: de onderlinge samenhangen tussen de geneigdheidscomponenten bieden daarvoor te weinig houvast.

Tabe 6.7 . Samenhangen tussen componenten van consumptiegeneigatheic (rho's)

\begin{tabular}{lllll}
1 & 2 & 3 & 4 & 5 \\
\hline
\end{tabular}

1. Vertrouwen in de medische zorg (vee) $\rightarrow$ weinig vertrouwen!

$.40 \quad .02 \quad-.25 \quad .12$

2. Attituden t.a.v. de eligen arts (pos. $\rightarrow$ neg.) $-.04 \quad-.27-.05$

3. Opvattingen over ziekte (onprofessionee 1

$\rightarrow$ professioneel) $-.05 \quad .16$

4. Zlektebe leving (slecht - goed) $-.13$

5. Gedrengintentie (aterk - gering)

$$
\square=\text { significant } p<.05 \quad(N=75)
$$




\section{WOTEN BIJ EOOFDSTUK 6}

1) Dit vragencomplex bevat in feite 23 items. Op grond van een reitief hoge partielle non-respons op drie exvar konden er silechts 20 in de analyse worden berrokken. De overige partielle non-respons werd vervangen door toekenning van gemidald scores.

2) Dadrvoor werden de items 1,2 en 3 in tegengestelde richting gecodeerd. Item nx. 5 correleerde niet significant met de schaalwarde.

Na verwijdering van dit item bedraagt de Hoyt-coefficient. 49 , hetgeen voor een schaal van vije items geen onbevredigend resultakt is. (Guilford, 1954).

3) In bijlage 4 is per patientencategorie aangegeven, on welke leefregels, lichamelijke verschijnselen etc. het gaat.

4) Op grond van de artsenenquete, zie hoofistuk 4

5) Op basis van de door Cassee gebruikte index van de globale geneigdheil tot het reageren op mogelijke ziekteverschijnselen. (cassee, 1973$, p. 5.6 en 5.7.$)$ 
Hoofastuk 7. Consumptiegeneigaheid: enkele samenhangen

\subsection{Inleiding}

Wij hebben nu verschillende componenten van consumptiegeneigdheid onderscheiden en geoperationaliseerd. In dit hoofdstuk worden vier vragen ten aanzien van die componenten gestela.

1. Bij de operationalisering is andacht besteed aan de mate warin de afzonderlijke genelgaheidscomponenten bepald worden door de aard van de aandoening. Daarbij kwamen wij tot de conclusie, dat de patientengroepen niet in inhoudelijk opzicht in consumptiegeneigdheid verschilien: hartinfarctpatienten houden er bijvoorbeeld geen wezenlijk anderssoortige ziekteopvattıngen op na dan psoriasispatienten. Het is echter nog mogelijk, ja zelfs waarschijnlijk, dat de patientencategorieën verschillen in intensiteit van consumptiegeneigdheid. Hierover werden in hoofdstuk 3 enkele veronderstellingen geformuleerd, ase in paragraaf 7.2. op hun houdbartheid worden getoetst.

2. In de tweede plats willen wij weten, in welke mate deze componenten nu ook werkelijk voorspellende waarde hebben ten aanzien van medische consumptie. Op dit vraagstuk wordt in deel IV nog uitgebreid ingegaan. Voorlopig willen wij hier een algemeen inzicht verschaffen in de predictiewarde van de vijf geneigdheidscomponenten (paragraaf 7.3. ).

3. Tenslotte stellen wij nog twee vragen, die wat gedetailleerder op de consumptiegeneigdheid ingaan. Wij willen weten in welke mate consumptiegeneigdheid samenhangt met relevant te achten persoonskenmerken, zoals geslacht, leeftijd etc. (paragraaf 7.4.) en

4. Op welke wijze kennis van medische zaken alsmede het rapporteren van psycho-somatische klachten met consumptiegenelgaheld verband houdt (paragraaf 7.5, ).

\subsection{Consumptiegeneigdheid van arie patientencategorieen}

In hoofdstuk 3 paragraaf 3 werden omtrent de relatie tussen consumptiegeneigdheid en bepalde kenmerken van chronischel aandoeningen de volgende veronderstellingen geformuleerd (hypothesen 1.1. en 1.2.). 
1. Namate de aandoening lewensbedreigender is en meer pljn en/of belemering veroorzakt, neemt de consumptiegeneigaheid toe. Hartinfaxctpatidnten zouden op grond van hun aandoening meex tot medische consumptie geneigd $z$ in dan diabetici en deze weer meer dan psoriasis-patienten.

2. Naarmate de aandoening langer duurt en zich geen bijzondere complicaties voordoen, neemt de consumptiegenelgdheld af.

Bif deze veronderstellingen is echter nog geen onderscheid gemaakt tussen de verschillende componenten van geneigdheid. Wij hebben in dat onderscheid inmidals wat meer inzicht gekregen (zie hoofdstuk 6: paragraaf 6.4), dat in de volgende paragrafen verder zal worden verdiept.

Deels op de resultaten daarvan wooruitlopend gaan wij ervan uit, dat de consumptiegeneigdheid relatief groot is als

- men vertrouwen heeft in de medische zorg

- men positief tegenover zijn arts staat

- men relatief professionele opvattingen over ziekte in het algemeen heeft

- men zijn ziekte slecht beleett

- men een sterke gedragsintentie ten aanzien van doktersconsulten bij bepalide symptomen tot uildrukking brengt.

Wij zullen nu de eerste veronderstelling toetsen door te bezien, of de patiëntencategorieën per component in de veronderstelde richting verschillen. Hiervoor wordt een énwegvarlantie-analyse toegepast. Tabel 7.1 . geeft de resultaten weer.

Deze tabel makt duidelijk, dat de arie patiëntencategorieër in geen enkele geneigdheidscomponent significant van elkatr verschilien. Dit is een zeex verrassende uitkomst. De hypothese over de verschilien tussen patientencategorieën ten aanzien van genetgdheidscomponenten moet op grond hiervan worden vermorpen.

Dezlet men de ultkomsten gezamenlijk, dan blijkt wel dat de scores van de hartinfarctpatienten op arie van de vije conponenten wijzen in de richting van een - vergeleken met de andere twee groepen - relatief grote consumptiegenelgaheid. 
Tabe1 7.1. Verschilien in vijf componenten van consumptiegeneigaheid tussen hartinfarct- (H), suiker- (s) en psoriasis- (P) patienten; eenweg variantie-analyse

gemidelde median s.a. F

1. vertrouwen in measche zorg (veel $\rightarrow$ weinlg)

totaad
$\mathrm{S}$
$\mathbf{P}$

$\begin{array}{llll}15,8 & 16,0 & 3,6 & \\ 15,3 & 14,1 & 2,9 & 0.48 \\ 16,1 & 16,0 & 4,5 & \text { N.S. } \\ 16,1 & 16,0 & 3,0 & \end{array}$

2. attitude t.a.w. arts (posttief $\rightarrow$ negatief)

totad
$\mathrm{H}$
$\mathrm{S}$
$\mathrm{P}$

26,8

26,8

27,1

26,4

38,6

36,8

39,2

40,1

16,3

15,2

16,5

17,0
38,0

36,9

38,0

41,5
26,5

25,8

27,0

26,8
8,5

$7,9 \quad 0.05$

10.9 N.S.

6.4

4. ziek tebeleving

(slecht $\rightarrow$ goed)

totala 1
H
F

$\begin{array}{ll}\mathrm{H} & 16 \\ \mathrm{~S} & 15 \\ \mathrm{P} & 16 \\ & 17\end{array}$

5. gedragsintentie

(sterk + gering)

totaal
S
$\mathrm{P}$

$$
\begin{aligned}
& 42,0 \\
& 39,5 \\
& 43,4 \\
& 43,0
\end{aligned}
$$$$
41,4
$$$$
9,0
$$$$
41,0
$$$$
44,0
$$

16,6

4,0

4,7

1. 34

17,6

3,8 N.S.

17,7

3,3

1.34

9.0 M.S.

7,3

P

41,2

9,0

10,8

16,6

De ziektebeleving van hartinfaxctpatienten is iets sechter dan due van de overigen $z i j$ stan het meest positief tegenover medische zorg in het algemeen en zij vertonem een ralatief sterke gedragsintentie. Wanneer men op deze wijze psorliasilspatienten met djabetici vergelijkt, blijken de eerstgenoemden in drie van de vije gevallen consumptiegeneigder te zijn dan de laatsten; in bun vertrowen in de medische zorg verschillen deze twee groepen helemal niet. Alleen de zlekte- 
belleving van psorlasispatidnten is relatief beter dan die van alabetici.

Al met al zljr de verschilen tussen de afzonderlijke scores - vooral tussen psoriasis-en suikerpatienten - echter zo gering, dat wij an deze rangverschillen verder geen betekenisi kunnen hechten. Wij komen daarmee tot de opmerkelijke conclusie, dat de hier bestudeerde chromische aandoeningen noch de ara, noch de intensiteit van de consumptiegeneigdheid zodanig beinwloeden, dat zich daardoor verschillen tussen de patientencategoriën voordoen. Voor de verdere analyse is dit van grote betekenis, ondat wij nu de steekproef als geheel kunnen bezien. Wij speken nu miet langer van de consumptiegeneigdheid van hartinfarct-, suiker- en psoriasispatiënten, maar van de consumptiegeneigdheid van chronische patienten.

De tweede verondersteling betreft de periade warin de patient weet dat hij of zij de aandoening heeft. Uitgangspunt is hlerbij de overweging, dat na een zekere tijd gewenning en/ of berusting in het chronisch ziek-zijn optreedt, waardoor de genelgdheld on medische hulp in te roepen zou afnemen kie ook hoofdstuk 3, paragraaf 3.2.1

De werkwijze bij de toetsing is als wolgt. De respondenten worden in twee groepen gesplitst; 47 van hen hebben de aandoening langer dan vijf jaax, 25 hebben sinds hooguit vijf jaar weet van hun hartinfarct, suikerziekte resp. psoriasts. Van drie respondenten was hierover geen informatie beschikbaar. Wij toetsen de afzonderlijke vijf genelgaheidscomponenten op verschillen in centrale tendentie tussen deze twee groepen (Mann-Whitney-u-toets, eenzijaig, tabel 7.2.).

Het blijkt at de twee groepen op gew van de deeluitkomsten significant van elkaar verschillen. Tezamen wijzen de resultaten slechts gedeeltelijk in de veronderstelde richting: personen met een langere ziektedur hebben minder vertrouwen in de medische zorg, een betere ziektebeleving en een minder stexke gedragintentie dan personen met een kortere ziekteduur. zij hebben darentegen een jets positievere attitude ton anzien van hun eigen arts en meer professionele zlekteoprattingen dar personen, die nog mar kort ziek zijn. Wij concluderen derhalve dat de ziektedur de consumptiegeneigdheid niet in 
Tabei 7.2, Verschillem tussen geneigaheldscomponenten nar zlektedury (Mann-binitmey-toets, eenzijaig)

ziektedur

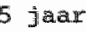

$(h+1)=4$

gem. rangnx.
$57 \operatorname{tar}$

$(\mathrm{A})=25$

gem: rangnx.

1. vertrouwen in medische zoxg: veel $\rightarrow$ weinig
37,3

35,6

38,1

39,3

37.1
34,9

0.47

N.S.

2. attitude t.a.v. axts: positief $\rightarrow$ negatiet

3. opvatingen over zilekte: onprofessionee $\rightarrow$ professioneel

4. ziektebeleving: slech $t \rightarrow$ goed

5. gedragsintentie: sterk $\rightarrow$ gering
$36.7 \quad 0.20 \quad$ N.S.

33,4

0.91

N.S.

31,3

1.56

N.S.

35,3

0.34

N.S.

de verwachte richting beinvloedt. Onze onderzoekshypothesen 1.1. en 1.2. over de rol, die de amdoeningen bij de gerneigdheid tot medische consumptie zouden spelen, worden met deze resultaten niet bevestigd.

\subsection{Consumptiegeneigdheid en medische consumptie: een eerste verkenming}

Ziju de in het vorige hoofdstuk op een bepalde manier geoperationaliseerde componenten van consumptiegeneigdheld geschikt om medische consumptie te voorspelien fonderzoekshypothese 2)?

Idealiter zou men deze vraag met resultaten van een experimentele onderzoeksopzet willen beantwoorden. Daarblj zou de consumptiegeneigdheid op en tijastip en de eventuele medische consumptie op een later tijdstip bij verschillende experimentele en controlegroepen gemeten moten worden. Onze ondezzoeksopzet - die immers niet uitsluitend gekozen 13 , om dexe vraag te beantworden - lat een dergelijke werkwijze niet toe. Wij verzamelden informatie op én tijatip, wardoor medische consumptie retrospectief gemeten moest worder en warbij wj slechts met enige plausibiliteit kunnen veronderstellem lmar niet volledig bewijzen) dat consumptiegenelgaheid een relatief 
stabiel gehee1 van attituden en opvattingen is, dat deze consumptie beinvloedt. Dit is een duldelijke beperking, die zich ook op andere agenblikken bij de analyse zal doen gelden. zij 1 s wel inherent an de meeste studies op dit gebied bijwoorbeeld ook bij Cassee, 1973, Jessen, 1974). In de sociaal wetenschappelijke 1 teratuur heef dit probleer veel aandacht gekregen (Tittle en Hill, 1975, Fishbein en Ajzen, 1975, recenteijk in Nederland: Huismans, 1980, Tijnstra, 1980), reden warom wij ex hier niet verder op ingaan.

om nu de vraag nar de predictilewarde van de geneigaheidscomponenten te kunnen beantwoorden, moeten wij eerst bepalen, wat in dit kadex onder medische consumptie zal worden verstaan. Medische consumptie vatten wij-zoals in hoofdstuk 2, paragrafif 2.1. betoogd - hier op als elk contact met het professionele systeem om gezondheidsredenen (Freidson, 1975). In de gesprekken met de patient-respondenten kwamen eventuele contacter met verschillende gezoncheidswerkers en gezondheidszorginstellingen ter sprake. Deze komen in deel IV nog an de orde. Voorlopig willen wij ons tot een nogal algemene indicator voor medische consumptie beperken, waarbij de reden voor at contact voorlopig buiten beschouwing blijft.

Het ligt voor de hand om hiervoor het antal huisartsconsulten te klezen. Men raadpleegt de huisarts meestal op eigen initiatief, wardoor zich de mogelijke invioed van consumptiegeneigdheid het best kan doen gelden. Hierbij moet echter met twee zaken rekening worden gehouden.

In de eerste plats $z i j$ exaan herinnerd, dat de respondenten zelf konden aangeven, tot welke professionele gezondheidswerker $z j j$ zich richten, als $z i j$ voor het hartinfarct, diabetes resp. psortasis behandeld willen worden. Men noemde in total 44 mal es specialist en 30 mal een huisarts. Daardoor doet zlch de vrag voor, of personen die opgaven door een specialist behandeld te worden, nu nawelijks meer contact met hun luisarts hebben. voor deze groep zou het aantal huisartsconsulten dan immers een slechte indicator voor medische consumptie vormen.

On at na te gaan, is de frequentie warmee men in de drife manden voorafgaand aan het onderzoek de huisarts had 
geradpleegd, apart voor huisarts- en speciallst-patienten bekeken. Tabel 7.3 geert aan, dat zich tussen de beide groepen geen significante verschillen op dit punt voordoen.

Tabel 7.3. Huisarts- en specialistpatienten nar het aantal malen wamee zij in arie manden voorafgaand ean het onderzoek hun huisarts consulteerden (absoluat; toets van wilcoxonll)

patienten van

\begin{tabular}{rcc} 
& huisartsen & specialisten \\
0 mal & 15 & 27 \\
1 maal & 11 & 7 \\
2 maal & - & 2 \\
3 maal & 1 & 3 \\
4 of 5 mal & 1 & 4 \\
6 of 9 maal & 1 & - \\
10 mal & 1 & 44 \\
\hline & 30 & N.S.
\end{tabular}

1) Deze variabele heeft voox wat de extreen-hoge warden betreft abor de codexing een ordinaal karakter. Waar in het vervolg sprake is van het antal (huis) artscontacten moet hiermee rekening worden gehouder.

In de tweede plats zullen bepalde huisartsconsulten niet op initiatief van de patient plaats vinden omdat het om regelmatig voorgeschreven controles gat. Het te onderzoeken verband tussen consumptiegeneigdheid en feltelijke consumptie moet hlervoor zoveel mogelijk worden gezuivera. Op welke wijze kan dat geschieden?

Men zou hiervoor gegevens willen gebruiken, die de bij het onderzoek betrokken artsen over de woorgeschreven controlefrequentie hebben verstrekt " De artsenenquete leverde echter op deze vraag slechts in 43 gevalien bruikbare informatie op.

De antworden die de respondenten over regelnatig voorgeschreven controles geven zijn vollediger. De correlatie tussen arts- en respondent-antwoordpatronen bedraagt rho $=.70$ (p <.001). De overeenkomst tussen beide gegevens is vrij bevredigend. Wij besloten daarom de "cortrolenoodzak" met het antwoord van de patiënten daarover te indiceren. De mogelijk grotere betrouwbarheid van de artsengegevens weegt niet op 
wegen het informatieveriles, dat zou ontstan als wij die gegeverws zouden gebruiken.

Als het te onderzoken verband tussen consumptiegeneigaheld en het radplegen van de huisarts met behulp van deze variabele gezuiverd wordt, dan redeneren wij echter nogal sterk in ons nadeel . Controles worden immers ook wel door specialisten voorgeschreven en uitgevoerd. De frequentie waarmee dat moet gebeuren heeft dan warschijnlijk geen invloed op het antal malen warmee men de huisarts raadpleegt. I) Als wif nu van het aantal huisartscontacten als het ware alle voorgeschreven consulten aftrekken, dan resteren hoogstwarschijndijk mirder huisartsbezoeken dan in werkelijkheid placts vonden. Met andere woorden: het verband tussen geneigdheidscomponenten en medische consumptie zou sterker voor contralenoodzaak woxden gezulverd, dan nodig zou zijn. Het aantal door huisartsen voorgeschreven controles is echter niet bekend, zodat wij deze werkwijze wel moeten volgen.

Tabel 7.4. geeft een eerste indruk. Daarin zijn nuldeorde correlaties (kendal1's'), weergegeven tussen geneigaheidscomponenten, het aantal huisartsconsulten en de controlenoa$z$ awk. Bovendien is a angegeven in welke mate de correlaties veranderen als voor controlenoodzaak wordt gecontroleerd. ${ }^{3)}$ be

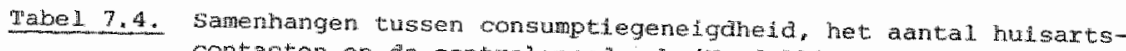
contacten en ale controlenoodzazk (kendali "s rangcorrelaties)

radplegern huigarts weinig $\rightarrow$ veel

\begin{tabular}{cccccc}
1 & 2 & 3 & 4 & 5 & 6 \\
\hline-.18 & {$[-.19]$} & .09 & {$[-.22$} & -.11 & 0.34 \\
-.10 & .09 & .10 & -.35 & .05 & \\
-.15 & -.24 & .06 & -.11 & -.13 &
\end{tabular}

controlenoodzaak welnig ir weel

xadulegen huj sats (gacontrolererd yoor controlenoodzak)

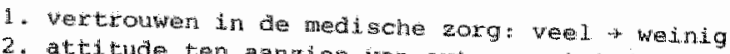

2. attitude ten arozen van axts: positiof $\rightarrow$ negatief

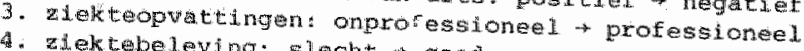

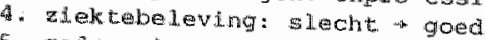

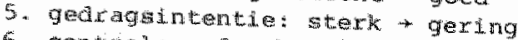

6. control noodeak : weing ver 
mulde-orde correlaties wertonen voor het merendeel een significante samenhang met de raadpleegfrequentie. Deze verdwijnt gedeeltelijk als voar de controlenoadzaak worat gecontroleerd. vooral met betrekking tot de ziektebeleving. Toch resteren ook dan correlatiecoëfficiënten, die en nadere analysie wan de invloed van de consumptiegeneigdheid op het antal huisartsconsulten rechtvaardigen.

De richting van de geconstateerde samenhangen geeft overigens een plausibel beeld te zien: opvattingen, die op vertrouwen in de meaische wetenschap wijzen, op ex positieve attitude ter aanzien van de arts en op een slechte ziektebeleving hangen samen met veel huisartsconsulten. De niet-significante correlatiecoëfficiënten wijzen, gezien hun teken, op een sterke gedragsintentie en relatief professionele ziekteopvattingen bij veel consulten. Dit latste komt overeen met bevindingen van veel buitenlands onderzoek (Suchman, 1966, King, 1962 , Freidson, 1961) maar is in tegenspraak met wat cassee vond. (Cassee, 1973, p. 77-79.) De samenhang tussen een traditionee1magische ziektebeleving en de raadpleegfrequentie was in zijn onderzoek zelfs nogal sterk ( $r=.33$ ). Het felt dat de correlatie hier in de andere richting wijst (maar niet significant is) kan wellicht worden toegeschreven aan een verschil in ondervraagde personen, aan de globale operationaliseringswijze van deze component (zie hoofdstuk 6) en mogelijk aan verandering van denkbeelden over ziekte en genezing bij het Nederlandse publiek tussen 1967 en 1979.

Kan er iets gezegd worden over de gezamenlijke predictiewarde van de vijf geneigaheidscomponenten voor het aantal hulsartsconsulten? Hiervoor stan ons twee mogelijkheden ter beschikking. Men kan de vijf geneigdheldscomponenten tot cen index verwerken en de invloed daarvan op de radpleegfreguentie bepalen. De vraag is echter, hoe men darbij te werk zou moeten gaan. In het vorige hoofdstuk werd opgemerkt, dat wij er bewust vanaf hebben gezien, om apriori veronderstellinger omtrent de onderlinge samenhang tussen geneigdheidscomponenten en hun invloed op de medische consumptie te formuleren. Dit stelt eisen aan de meting van de afzonderlijke componenten, waraan 0.1 . op het terrein van ziekte en medische consumptie 
niet kan worden voldaan. Kan men langs empirische weg laposterioril tot schalconstructie en darmee tot éch index voor consumptiegeneigaheid komen? Het correlatiepatroon tussen de variabelen onderling (tabel 6.7.) biedt darvoor weinig houvast. De opvatingen over ziekte en de gedragsintentie zouden geen deel uitmaken van een op grond daarvan samengestelde index.

Een tweede mogelijkheid om iets over de gezameniljke predietlewarde wan de geneigdheidscomponenten te zeggen, biedt toepassing van regressie-analyse. Deze techniek stelt evenwel etsen aar het material, waraan het onze niet voldoet, vooral omdat het slechts 75 analyse-eenheden bevat. 4 .

Wij kiezen van twee kwaden de minste. De verleiding tot het gebruik van regressie-analyse is groot en wij maken liever een statistische dan een theoretische fout.

Tabel 7.5. geeft de resultaten weer var een stapsgewijze regressiemalyse met het antal huisartsconsulten als afhankelijke varibele. De controlenoodzak werd als eerste stap Ingevoexd on te kummen bepalen, hoeveel varlantie in medische consumptie daarma nog door de vijf geneigdheidscomponenten kan worden verklaard. De volgorde warmee deze vijf onathankelijken in de analyses werden betrokken, werd bepald door de hoogte van hun - resterende - correlatie met de afhankelijke variabele.

Hierult blijkt dat de geneigdheidscomponenten een signiflcant deel van de variantie in de raadpleegfrequentie verklaren. Darbij spelen de ziektebeleving, de attitude ten a anzien van de eigen arts en de gedragsintentie allen een ongeveer gelijke en significante rol. De bijaragen van de (on)professiomele opwatwingen over ziekte en over gezondheidszorg zijn geranger en niet significant.

Wu is ons onderzoek everwel op eer bepalde wjoe opgezet. Juist met het oogmerk on de invioed van consumptiegeneiganeid duidelifk te kunnen traceren. Daarvoor z⿺jn andere belangrjke determinanten van medische consumptle zoveel mogelijk gelijkgesohekeld. Dit geldt in ieder geval voor het variabelencomplex, dat met "consumptenoodzak" wordt aangeduid, omdat wis chronische patienten ondervioegen. Volgens onze 
Tabel 7.5. De mate waarin de vijf genelgaheidscomponenten het adntal huisartsconsulten verklaren istapsgewijze regresiste-analyse; gezuiverd voor voorgesichreven controles, $N=7$ thy

\begin{tabular}{|c|c|c|c|c|}
\hline $\begin{array}{l}\text { onafhankelijke } \\
\text { variabelen }\end{array}$ & $\begin{array}{l}\text { toegevoegde } \\
\text { verkl. variantie }\end{array}$ & $\begin{array}{l}\text { partiele regr. } \\
\text { coêticient }(6)\end{array}$ & $F^{*}$ & si.gra. \\
\hline controlenoodzaak & 11.0 & .23 & 4.04 & $p<.001$ \\
\hline atcitude t.a.w axts & & & & \\
\hline & 8.4 & -30 & 6.36 & $\mathrm{p}<.001$ \\
\hline $\begin{array}{l}\text { gedragsintentie } \\
\text { sterk } \rightarrow \text { gering }\end{array}$ & 5.1 & -.25 & 5.68 & $p<.001$ \\
\hline $\begin{array}{l}\text { zlektebeleving } \\
\text { slecht } \rightarrow \text { goed }\end{array}$ & 6.1 & -.31 & 6.90 & $\mathrm{p}<.001$ \\
\hline $\begin{array}{l}\text { wertrouwen in med, zor } \\
\text { weel weinig }\end{array}$ & 1.1 & -.12 & 1.02 & N. 5 . \\
\hline $\begin{array}{l}\text { opvattingen over ziek } \\
\text { onprof. } \rightarrow \text { profession. }\end{array}$ & 0.1 & .04 & 0.17 & N. S. \\
\hline $\begin{array}{l}\text { totalal } x^{2} \text { door cons. } \\
\text { genelgaheid }\end{array}$ & 20.8 & & 3.57 & $\mathrm{p}<.01$ \\
\hline totacl $x^{2}$ & $31.9 \mathrm{~g}$ & & 5.22 & $p<.001$ \\
\hline
\end{tabular}

1) Bljlage 7 bevat de matrix van product-moment correlaties

theoretische uitgangspunten lag een relatief grote invloed van de geneigdbeidscomponenten in de lijn der verwachting. Bij de ultkomst zijn echter twee kanttekeningen te plattsen, die exop wijeen, dat de predictiewarde van de vijf geneigaheidscomponenten groter is, dan uit tabel 7.5. blijkt.

In de eerste plats mot men bedenken, dat door de onderzoeksopzet niet alleen "storende" unvloeden ziju geellimineera. Tegelijk daamee verdwijnen immers ook die invloeden van de geneigdheidscomponenten, die aan interactie-effecten van gelijkgeschakelde determinanter en consumptiegenelgaheld zlin toe te schrifven. Over de omvang dadrvan kunnen wij echter geen udtspraak doen.

In de tweede plats moet worden opgemerkt, dat de frequentie warmee men volgens eigen zeggen voor controle of onderzoek naar de dokter moet, in sterke mate met ziektebeleving 
sanenhangt $r=.41, \mathrm{p} \leq .001$; bij relatier slechte ziektebe wing veel controles; vergelijke ook tabel 7.4.$)$. Dit is wij gemakkelijk in te zien als men bedenkt, dat de controlefregu the vermoedelijk groter is naamate de aandoening ernstiger ok de wijze waxap de patiënt de ziekte beleeft zal net toe. nemende ernst ervar warschijnlifk relatief slechter worden. Door nu echtew deze controlefrequentie als eerste stap in de regressiemanalyse te betrekken, wordt ook een deel van het effect yan de varlabele ziektebeleving uitgeschakeld. Hierbi: herinneren wij exaan, dat ook de gekozen operationalisering van de controlenoodzadk in ons nadeel werkt.

Ter vergelijking geven wij darom de uitkonst van de stapsgewljze regressie weer, warbij de controlenoodzaak buiten beschouwing bleef (tabel 7.6.). Nu blijkt ziektebeleving inderdad - gezien de R-warde - de belangrijkste determinant van huisartsenbezoek te zijn. De vijf gemeigdheidscomponenten verklaren op deze wijze bijna 28 z van de variantie in de criteriumvariabele, hetgeen duidelijk significant is.

Tot besluit willen wij nog in het kort aandacht besteden aan de reden voor het doktersconsult. In hoofdstuk 3 veronder stelden wij, dat het wak moeilijk zal zijn, om bij chronisch patienten een precies onderscheid te maken tussen hun contacten met de huisarts voor de aandoening in kwestie en contacte voor iets anders. Wij kunnen deze veronderstelling hier niet verder witzoeken. Wij kunnen echter wel nagaan, of de invloed van de consumptiegeneigdheid verschilt van hetgeen in het voo: gaande werd gevonden, als huisartsconsulten worden bezien, di uitsluitend met het hartinfarct, de suikerziekte of psoxiasis verband houden. zestien respondenten, die (mede) voor lets ancers en beroek an de huisarts hadder gebracht, ajn hiervoor buiten een analyse gehouden, warvan de resultaten in tabe1.7.7. zijn weergegeven.

ook nu blijken attitude ten aanzien van de arts, gedragsintentie en ziektebeleving een zelfstandige. significamte invioed utt te oefenen. Het percentage verklaarde variantie is grotex dan dat in tabel 7.6 . evenals de mate van invloed ( $\beta$ ) van de attitude ten aarien van de arts en de gedragsintentie. De invloed van het vertrouwen in de medische zorg is daaren- 
Tabel 7.6. De mate warin de vijf geneigoheidscomponenten het aantal huisartsconsulten werklaren (stapsgewi yte regressie-analyse, zonder dat voor voorgeschreven controles werd gezuivera $(N=74) 11$

\begin{tabular}{|c|c|c|c|c|c|}
\hline $\begin{array}{l}\text { onathankelijke } \\
\text { variabelen }\end{array}$ & $\begin{array}{l}\text { oegevoegde } \\
\text { 1. variantie }\end{array}$ & $\begin{array}{l}\text { partiele } \\
\text { coefficie }\end{array}$ & F & & $\operatorname{sighn}$. \\
\hline \multicolumn{6}{|l|}{ 2lektebeleving } \\
\hline$\rightarrow$ goed & 7.4 & -.41 & 14.45 & $\mathrm{p}$ & $<.001$ \\
\hline $\begin{array}{l}\text { attitude t.a.v. } \\
\text { arts - negatief }\end{array}$ & 11.1 & -.27 & 5.26 & $p$ & $<.001$ \\
\hline \multicolumn{6}{|l|}{ gedragsintentie } \\
\hline - gering & 6.2 & -.25 & 5.42 & $\mathrm{p}$ & $<.001$ \\
\hline & 2.6 & -.18 & 2.27 & vertrowwen in de & N.S. \\
\hline $\begin{array}{l}\text { opvattingen over } \\
\text { ziekte } \rightarrow \text { professioneel. }\end{array}$ & 0.4 & .07 & 0.41 & & $\mathbb{N}_{*} S$ \\
\hline
\end{tabular}

1) zie bijlage 7 voor de matrix van product-monent correlaties

Tabe1. 7.7. De mate waxin vijE geneigdheidscomponenten het aantal huisartsconsulten ditsluitend t.b.v. de chronische aandoening verkiaren (stapsgewlyze regressie-analyse, gezulverd voor poorgeschreven controles, $N=59$, 1)

\begin{tabular}{|c|c|c|c|c|}
\hline $\begin{array}{l}\text { onafhankel ijjke } \\
\text { variabelen }\end{array}$ & $\begin{array}{l}\text { toegevoegde } \\
\text { verki, varlantie }\end{array}$ & $\begin{array}{l}\text { partidie regr }{ }^{-} \\
\text {coefficient }(\beta)\end{array}$ & $\mathbb{F}$ & sign. \\
\hline control enoodzaak & 7.1 & .19 & 2.34 & $\mathrm{p}<.05$ \\
\hline $\begin{array}{l}\text { attitude arts } \\
\text { fpos. } \rightarrow \text { neg. } 1\end{array}$ & 12.5 & -.34 & 6.16 & $p<.001$ \\
\hline $\begin{array}{l}\text { gedragsintentie } \\
\text { (stexk } \rightarrow \text { gering) }\end{array}$ & 9.5 & -.34 & 8.68 & $p<.001$ \\
\hline $\begin{array}{l}\text { ziektebelleving } \\
\text { (slecht } \rightarrow \text { goed) }\end{array}$ & 7.1 & -.30 & 5.71 & $p<.00 \mathbb{1}$ \\
\hline $\begin{array}{l}\text { zlekteopvattingen } \\
\text { (anprof. } \rightarrow \text { profession.) }\end{array}$ & 0.1 & .03 & 0.00 & $M, S$. \\
\hline $\begin{array}{l}\text { vertr. In med zorg } \\
\text { (veel w weinig) }\end{array}$ & 0.1 & $=.04$ & 0.07 & N. \\
\hline $\begin{array}{l}\text { towall } x^{2} \text { door } \\
\text { cons. geneigoheid }\end{array}$ & 29.2 & & 4.30 & $P<01$ \\
\hline totaal $x^{2}$ & 36.3 & & 5.94 & $\mathrm{p}<.001$ \\
\hline
\end{tabular}

1) aie bijlage 8 voor de matrix van product-montent correlaties. 
tegen iets geringer. De verschilien ain evenwel niet zo (men moet ook rekening houden met het verschil in het ant wamemeningen), dat wij darut werdere conclusies kunnen trekken.

Het voorgaande makt duldelijk, dat de vijf gekozen e op bepalde wijze geoperationaliseexde componenter wan con sumptiegenelgdheld gezmenlijk als goede voorspellers van medische consumptie (in texmen van huisartsconsulten) kunne gelder. Het blijkt verder, dat de attituden en de gedragsjr tie daarvoor belangrijker zijn dan de opvattingen. Dit komt overeen met de bevindingen van ormel. (In: Jessen, $1974, p$.

\subsection{Consumptiegeneigdheid en persoonskenmerken}

Men kan zich afvragen in welke mate de viff geneigdhein componenten samenhangen met bepaalde kenmerken van de persoc Hermee bedoelen wij structurele kemerken, geen persoonlijk heidselgenschappen. Op grond van onderzoksresulaten van an deren met betrekking tot de determinanten van medische consumptie kan men aannemen, dat iemands leeftija, geslacht, op leiding en eventueel iemands burgerlijke stat of woonplaats un termen van urbanisatiegraad van invloed kunnen zijn op $z i$. of hat consumptiegeneigaheid vergelijke hoofastuk 4 , paragraaf 4.2., alsmede Hochbaum, 1958, Mc Kinlay, 1972, Rosenstack, 1974). Of en in welke mate dat ook voor chronische patiënten gelat, valt moeilijk te zeggen ${ }^{5}$.

Deze paragraaf stelt di.t vraagstuk in het kort an de orde. Wij anderzoeken de samenharg tussen consumptiegeneigdheid en persoonskemerken echter niet, om bepalde geneigdheidscomponenten bij bepalale bevolkingscategorieän te willen localiseren. Ons onderzoek richt zich niet op deze probleemstelling en is voor de bestudering ervan ongeschikt. Wat voor onze problemsteling in alt verband wel wan belang is. is de mate warin wij met de invloeden wan persoonskenmerken rekening moet $n$ houden. Deze invloeden zijn voor de probleemstelIing immers als storend te zien, reden waxom bij de steekproefsamensteling enkele persoonskenmerken zoveel nogelijk zijn gelijkgeschakeld. 
Tabel 7.8. geeft een inzicht in de samenhang tussen de vijf componenten van consumptiegeneigaheld en enkele in dit verband relevante persoonskenmerken.

Tabel 7.8. Correlaties (Spearmam's rho) van vije geneigdheidsconoonenten en enkele persoonskenmerken. $(N=75)$

geneigdheldscomponemten:

persoonskernmerken

leeftijd

jong + oud

opleiding

laag + hoog

geslacht

man $\rightarrow$ vrouw

urbanisatiegraad

land $\rightarrow$ stad

burgerlijjke staat

gehum + anders dan gehuwd

\begin{tabular}{ccccc}
1 & 2 & 3 & 4 & 5 \\
\hline-.14 & -.07 & -.17 & .18 & {$[-.19$} \\
-.32 & .01 & .31 & -.07 & .21 \\
-.10 & .10 & .16 & -.01 & .03 \\
-.16 & .00 & .12 & -.08 & .13 \\
.04 & .00 & -.02 & -.13 & .03
\end{tabular}

$\square=\operatorname{signilicant}$ bij $\mathrm{p}<.05$

1. vertrowwen in de medische zorg: veel t welnig

2. attitude ten anzien van arts: positiet + negatief

3. ziekteopvatingen: onprofessionee 1 th professioneel

4. ziektebeleving * wecht $*$ goed

5. gedragintentie: sterk $\rightarrow$ gering

De conclusie is duidelijk: persoonskenmerken spelen een bescheiden rol bij: de mate warin de respondenten geneigd zijn om medische hulp in te roepen. De twee belangrijkste determinanten van medische consumptie - de ziektebeleving en de attitude ten aanzien van de arts - hangen met geen enkel van de hier genoemde persoonskenterken significant samen. Het valt vooral op, dat geslacht blijkbaar helemal geen invloed heeft op consumptiegeneigdheid. Men moet op grond van de resultaten van anderen aanemen, dat er sprake is van interactie met het hebben van een aandoenung: geslacht speelt een grotere rol bij consumptiegeneigdheid bij acute en/of nieuwe, althans niet chronische kiachten. De inwloed van het man of vrouw zijn op die geneigdheid neemt kennelijk af, narmate men bepaalde chronische andoeningen heet. 
Uit tabel 7.8. bijken in felte slechts twee dingen. Ten eferte: personen met een lage opleiding hebben minder professonele zlekteopwatingen, hebben minder vertrouwen in de medische zorg en zijn eerder geneigd, bij bepalide klachten de dokter te radplegen, dan personen met een hoge opleiding. Deze conclusie slutt duidelijk aan bij bevindingen van anderem (Cartwright, 1967, Cassee, 1973, p. 27). In algemene zin verwjst zif naar een "Dopular health oritentation" van lager opgeleiden (Freidson, 1961, Suchman, 1966).

Ten theare: Jonge mensen zijn minder snel geneiga om met bepalde lichamelijke werschijnselen de arts te consulteren, dan oude mensen. "6) ook deze conclusie lijkt plausibel: de in de gedragsintentielijst door ons genoemde symptomen $z i j n$ over het algemeen niet errstig. De idee, dat men niet met elke klacht bij de dokter aanklopt, max veelal eerst afwacht, of de verschijnselen vanzelf verdwijnen, is bij deze respondenten vermoedelijk meer bij jongeren dan bij ouderen verspreid.

Samenvattend: de relatie tussen de viff geneigdheidscomponenten en de - op grond van bevindingen van anderen - belangrijkste persoonskenmerken is bij de door ons onderzochte groep zwak. De analyse bracht wel an het licht, dat - zo er al sprake is van enige relatie op dit purt - deze blijkt bij de iekte- en zorgopvattingen en bij de gearagsintentie.

\subsection{Medische kennis, stress en consumptiegenelgdheid}

\subsubsection{Inleting}

Bij het onderzoek naar determinanten van medische consumptie zijn twee verschijnselen van belang, aie veelal met consumptiegenelgaheid in verband worden gebracht. Wij bedoeIen lemands kennis van medische zaken enerzijds, en de mate warin hij geneigd is psycho-sociale klachten te uiten anderzijds.

De rol die lemands medische kennis bij het inroepen van doktersadviezen speelt, is niet zonder meex duidelijk (Mo kinlay, 1972 op basis van een ultgebreld literaturonderzoek, Giesbers e.a., 1977). Dit moet mede worden toegeschreven aan het feit, dat het verwerven en vooral het juist anwenden van 
deze kennis naw samenhangt met het social-culturele milleu warin iemand verblijft. De invloed daarvan op medische consumptie is echter - zoals bekend - nogal complex. Men mag wel aamemen, dat de invloed van medische kennis afneemt, naarmate er meer andere motivationele factoren een rol spelen bij de beslissing, de dokter te radplegen (Hochbaum, 1958, Feldmann, 1966, Tagliacozzo, 1970). Daarbij kan ook het feit, dat iemand een bepaalde (chronische) aandoening heeft van belang 1 in (Kutnex en Gordon, 1961, Archer, 1967, Bloks en De Graaff, 1978). Hoe hangt de medische kennis van chronische patienten nu samen met hun consumptiegeneigdheid? Wellke hypothesen kan men daarover formuleren?

Mede gezien de resultaten uit de vorige paragrafi kan men verwachten, dat de hoeveelheid medische kemis met iemands opieidingsniveau en daarmee met zijn opvattingen over ziekte en medische zorg zal samenhangen. Weinig professionele ziekteopvattingen en weinig vertrouwen in de medische zorg zullen vermoedelijk samengaan met weinig medische kennis. Voorts kan men aannemen, dat weinig kennis samengat met de neiging, om bij vage lichamelijke verschijnselen de axts te raadplegen (gedragsintentie). Deze aanname baseren wij eveneens op de invloed van de opleiding op de gedragsintentie. over de invloed van kennis op attituden ten aanzien van de eigen axts en de ziektebeleving durven wij gezien de ontbrekende onderzaeksresultaten op dit punt, geen verwachting uit te spreken.

Sinds het verschijnen van Dixkens proefschrift (Dirken, 1969) wordt het door hem ontwikkelde meetinstrument, de Vragenlijst Onderzoek Ervaren Gezondheidstoestand (V.O.E.G.), in veel Nederlands onderzoek naar de determinaten van medische consumptie toegepast (Cassee, 1973, Van der Mas, 1974, C.B.S., Leefsituatieonderzoeken, 1974 en 1977, van Bjjk, 1979, van der Ploeg, 1980/. Deze vragenlijst indiceert de mate warin denand stress heeft door bepalde vegetatieve functieveranderingen te inventariseren. Wij willen in dit kader niet nader ungaan op de stress-theorieën, die aan Dirkens werk ten grondslag liggen rie hierwoor vooral seley, 1956, Howard en Scott, 1965 , Wan Eijk, 1979, Orme1, 1980). Het is wel duldelijk, dat de mate warin iemand geneigd is om spanningen om te zetten in 
11 chamelijke klachten, zijn consumptiegeneigaheld kan bernvloeden. Wij stellen hier dan ook de vraag op welke wijze stress, gerteten met behulp van de V.O.E.G. samenhangt met de doot ons onderscheiden geneigdheldscomponenten.

Wij verwachten eigenijik slechts ến duichelijke ujtkomst: natamate de zlektebeleving slechter is, zal de V.o.E.C.-score hoger zijn. Wij werwachten dit on twee redenen. In de eerste plats wjien de variabelen, die tezamen de ziektebeleving indiceren, iedex afzonderlijk op het ondervinden van stress: men is ongerust ovex de aandoening, krijgt er ten gevolge van spaningen meer last van etc. Voorts is bekend, dat de V.O.E.G.-score bij zieke mensen hoger is dan bij gezonden. Dit niet alleen omdat iekte stress tot gevolg heeft, mar omdat de V.O.E.G. nu eenmal lichamelijke klachten registreert. ${ }^{7}$ ) zoals eexdex apgemerkt hangt wermoedelijk ook hier de gemeten alektebeleving - hoewel zwak en theoretisch niet bedoeld, zie hoofdstuk 3, paragraaf 3.1.2. - samen met de "objectieve" gezondheidstoestand van de persoon. Daardoor kan een relatie met de V.O.E.G.-score worden verwacht (zie schema).

Schema: Veronderstelde relaties tussen V.o.E.G.-score en ziektebeleving

(1) ziekte $\longrightarrow$ stress

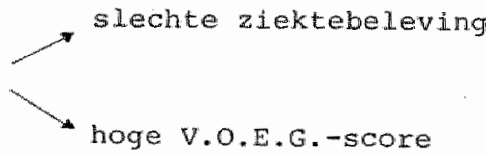

ziekte

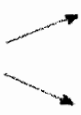

hoge V.O.E.G.-score

slechte ziektebeleving

Over het verband met de overige geneigdheidscomponenten en gtress kunnen wij-gezien de resultaten van anderen mare weinlg zeggen. Men kan hooguit aannemen, dat een hoge V.O.E.G.-score met en sterke gedragsintentie zal samengaan, omdat belde variabelen een zekere klaagneiging weerspiegelen.

Voor de wijze warop medische kennis en stress (V.O.E.G.score) in dit onderzoek precies zijn gemeten zij verwezen naar bijlage 9 . 
7.5.2. Medische Kennis, medische consumptie en consumptiegeneigdheld van chronische patienten

Tabel 7.9. geeft weer, hoe medische kennis met het antal huisartsconsulter en met consumptiegeneigdheid samemhangt.

Tabe1 7.9. Samenhangen tussen medische kennis, het antial hus sayteconsul tem en consumptiegeneigahe $(N=75)(x h 0: s)$

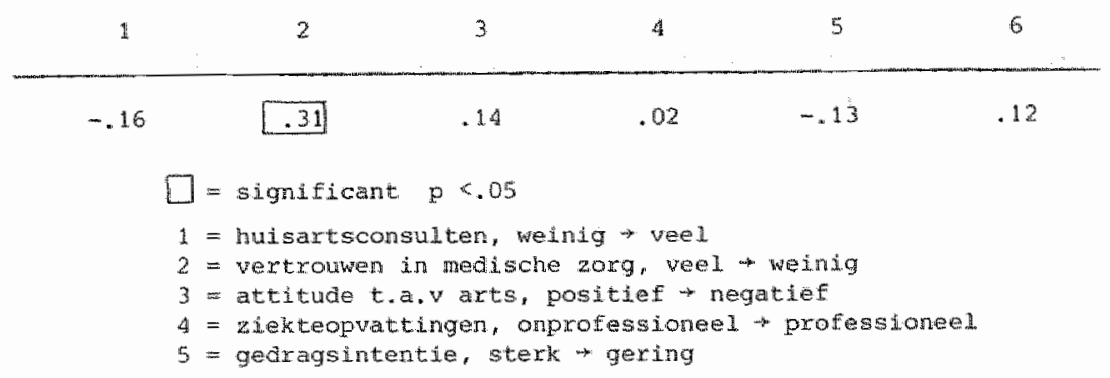

Deze samenhang is niet groot. Alleen blijkt, dat reel medische kennis gepaard gaat met weinig vertrowwen in de medische zorg. Alle overige verbanden zijn niet significant. Gezien onze verwachtingen vallon vooral de lage correlaties met (on)professionele ziekteopvattingen de gedragsintentie op. Zij doen de vraag rijzen of een lage opleiding in dit onderzoek wel, zoals in ander onderzoek, met geringe medische kemis samengaat. Dat blijkt dan ook nawwelijks het geval te zijn: tho opleiding $x$ kennis $=.10$ (N.S.)

Hieruit kan men wellicht afleiden, dat aan het vergaren van specifieke kennis over een chronische aandoening watraan men zelf lijat (zie bijlage 9 voor de operationalisering van medische kennis), andere mechanismen ter grohdsiag 11 ggen, dan aan het verzamelen van medische kennis in het algemeen. Dat latste geschiedt vermoedelijk geleidelijk en minder bewast, warbij het opleidingsniveau een grotere rol speelt dan bij het eerste.

Algemeen blijkt echter, dat deze specifieke kennis voor medische consumptie niet zo belangrijk is. Alleen de xichtingen van de correlatiecoẹficiënten wijzen erop, dat veel van deze medische kemris samen gat met een geringe consumptiegeneigdheid - zoals gezegd: wel duidelijk met weinig vertrouwen in 
de medische zorg - en darmee ook met relatief weinig huisartscontacten.

\subsubsection{Stress, consumptiegeneigdheid en medische consumptie} van chronische patienten

De correlaties tuswen stress, consumptegeneigdheld en het antal huisartaconsulten zijn te zien in tabel 7.10. Twee resultaten springen in het oog: de samenhang met de ziektebelewing 1 s niet significant en de samenhang met de gedragsintentie is tegengesteld aan onze verwachting. Het blijkt dat en hoge V.O.E.G.-score juist samengat met eengeringe gedragsintentie. De negatieve correlatie met de ziekteopvattingen is warschijnlijk toe te schrijuen aan het felt, dat mensen met een lage opleiding relatief veel stress hebben (rho: opleiding $x$ V.O.E.G. $=.27, p<.01$ ) en er ook weinig professionele zlekteopyatingen op nahouden. De twee andere ultkomsten zijn evenwel zo verbazend, dat $z$ ij om een nadere analyse vragen.

Tabre1 7.10. Samenhanger tussen stress (V, 0, E.6. -score), het aantal huisartsconsulten en consumptiegenetgaheid $(n=75)(x h)^{\prime} s$ )

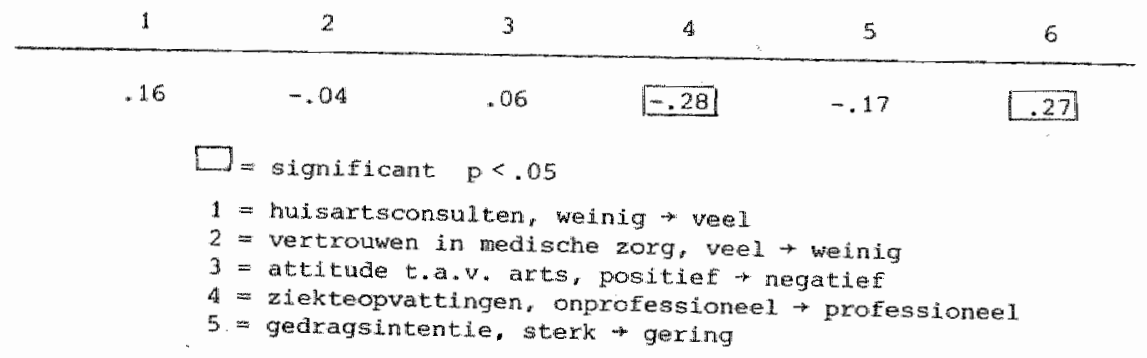

Waarom zou een relatief slechte ziektebeleving tegen de verwachting in niet met stress (V.O.E.G.-score) gepaard gaan? zouden chrondsche patienten op dit punt anders reageren, dan de (min of meer) gezonde mensen, die wij ult ander onderzoek kennem? En warrom zouden onze respondenten tegenover een enguirice vele peycho-somatische klachten (hoge V.O.E.G.score) uiten, max juist niet genelga zijn, om over vage verschijnselen bij de arts te zullen klagen (lage gedragsinten-
tie)? 
Wif gingen vermoeden, dat een bepaalde ervaring, opgedaan net de chronische abndoening en/of met de arts hierbij een rol zou kumen spelen. Wij werden in dit vermoeden gesteund door ormel (1980), aie aannemt, dat ".. iemands nelging tot zlektegedrag zoals het besteden van aandacht aan onlustgevoelens daalt ... tijdens een periode van toegenomen onwelbevinden" (ome1, 1980, p. 285; z1e ook pag. 227-228 en pag. 267-271).

De eerste tijd warin iemand de rol van chronisch patient moet aannemen, kan zeer goed tot een "periode van toegenonen onwelbevinden" leiden, waarin hij die neiging tot wektegedrag ("onze" gedragsintentie) als het ware verdringt. Deze hypothese sluit tot op zekere hoogte aan bij bevindingen over uitstel van doktersbezoek (o.g.v. een geringe gedragsintentie). De uitstelduur is langer bij mensen met vage onlustgevaelens (Cassee, 1973, p. 107, Jessen, 1974, p. 43) en - In verband met minder ernstige klachten - bij mensen, die meer ervaring hebben met de klacht (Neven, 1980, p. 91).

On dit vermoeden nader te onderbowwen splitsten $1 j$ de steekproef in twee delen en berekenden de genoemde correlaties afzonderlijk voor personen, die hun andoening minder dan vijf jaar hebben en voor personen, die daarmee al langer dan vijf jaar ervaring opdoen. Ondat de controlenoodzalk aarbij nog een belangrijke rol kan spelen, is deze variabele in de correlatiematrix opgenomen (tabel 7.11 .1 .

De uitkomst is verbluffend. Het verband tussen ziektebeleving en stress (V.O.E.G.-scoxe) blijkt vaor hen, die nog maar kort ziek $z i j n$, overduidelijk aanwezlig. Het samengaan van veel stress en een geringe gedragsintentie is bij deze groep sterker, dan bij de andere groep. Dar verliest het zijn significantieniveau.

Wij menen, dat een en ander als volgt geinterpreteerd kan worden. De chronische aandoening is te zien als stressor (Howard en scott, 1965 , Mechanic, 1968). Mensen, die pas kort weten dat zij een chronische aandoening hebber, weten daamee nog geen raad. zij hebben nog onvoldoende gelegenheid gehad, om aan hun veranderde saclale rol te wennen. zij weten nog niet hoe zij zich als chronisch patient behoren te gedragen en wat wan hen werwacht wardt, zorgen om de adndoening, zich er- 


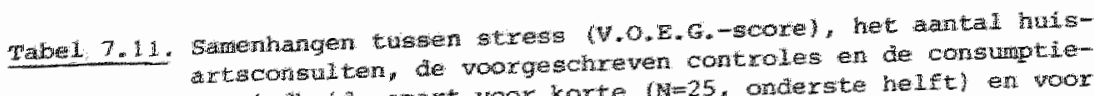

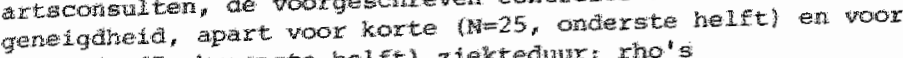

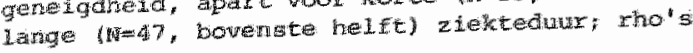

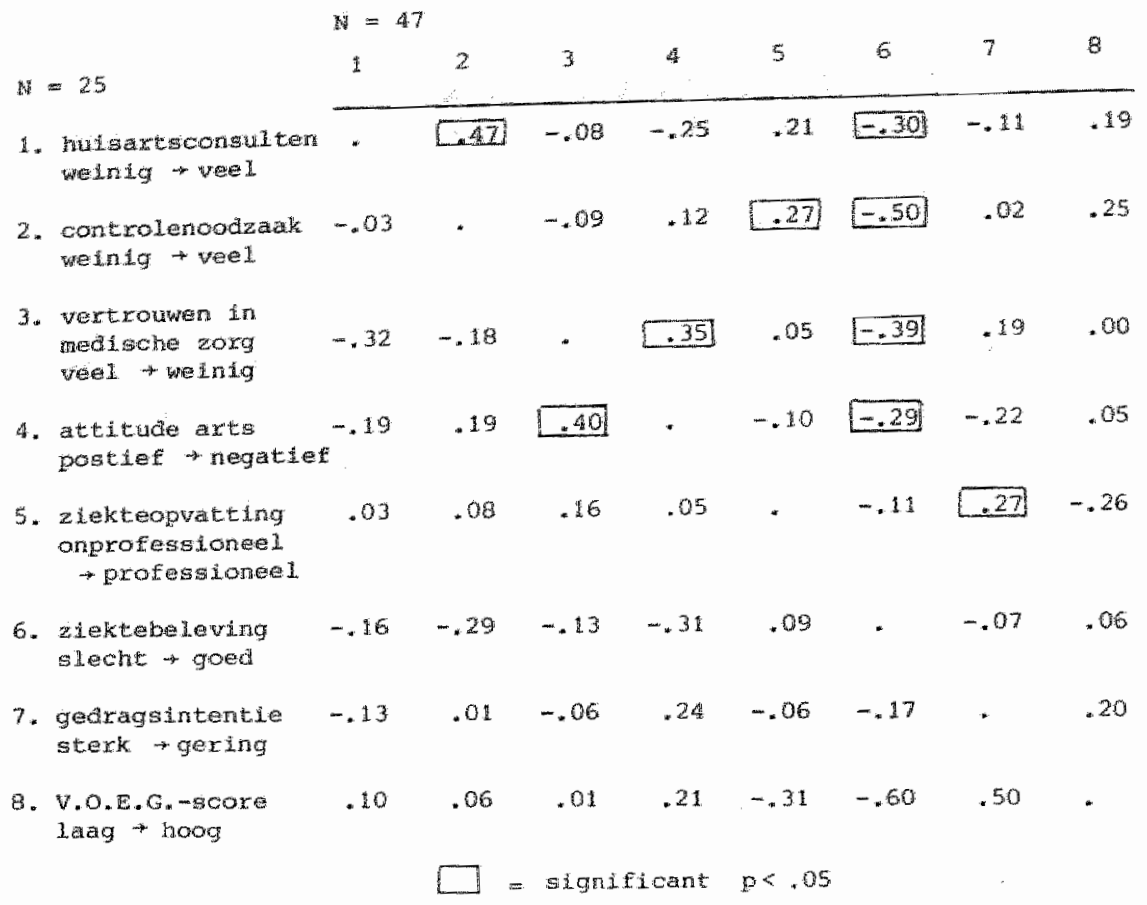

mee ziek achten etc. (d.w.z. een slechte ziektebeleving) heet bij deze psychisch onuitgebalanweerde mensen stress lhoge W.O.E.G.-scorel tot gerolg. Een van de mogelijke reacties op stress in een dexgelijke situatie zou een huisaxtsconsult kurnen $z 1 j n$, ondat de arts de patient bijvoorbeeld bepalde advitezen kan geven of hem gerust kan stellen. Maar deze vorm van "problemoplossend gedrag" (Howard en scott, 1965, ormel, 1980) makk bij deze mensen nog geen deel uit wan hun sociale rol. Integendeel: zif onderdxukken elke neiging tot ziektegedrag (gedragsintentie) en zeggen vemoedelijk de arts niet met "klelme kwaltjes" te willen lastig vallen.

Mensen die datentegen langet ziek zijn, bekleden een sociale rol van een meer stabiel karakter. Daarin heeft vooral 
de verhouding met de arts vorm kunnen krijgen: de patient kent zijn eigen werwachtingen ten aanzien van de arts en weet, hoe de arts op zijn ziektegedrag reageert. Een slechte beleving van de chronische 2 lekte heeft bij deze mensen geen stress (v.o.E.G.-score), mar wel relatief veel huisartsconsulten, een regatieve attitude ten aanzien van de arts en weinig vertrowwen in de medische zorg tot gevolg. Professionele ziekteopvattingen hebben zij als het ware "vertald" in relatief veel voorgeschreven controles. Al deze reacties passen goed bij de rol van chronisch patiënt. De door ons gemeten gedragsintentie wordt door hen vermoedelijk niet eens meer in verband gebracht met hun aandoening. $z i j$ reageren op de vragen betreffende de gearagsintentle eerder rationeel dan emotioneel. Het is dan ook plausibel, dat een op deze wijze gemeten geringe gedragsintentie bij hen met relatief professionele ziekteopvattingen samenhangt.

Deze interpretatie is - woorzover het de samenhang tussen ziektebeleving en stress (V.O.E.G.-score) betreft - in feite geheel in overeensteming net algemene stress-theorieän. Het meetinstrument van Dirken meet immers fysiologische reacties op onverwerkte spanningen. zodra deze spanningen echter worden ongezet in succesval "probleemoplossend gedrag" valt de stress weg. Voorts is het niet onwarschijnlijk, dat de gedragsintentie bjj min of meer gezonde mensen een voornamelijk cognitief gegeven meet, terwijl de desbetreffende vragen door nog niet zo lang chronisch zieke respondenten tegen de achtergrond van de eigen aandoening worden beantwoord, wardoor deze dan een meer emotioneel gegeven indiceren.

A1. met al heeft ons deze exercitie nogal ver van onze oorspronkelijke probleemstelling verwijderd. Na een korte samenvatting wan dit deel zullen wij daarom overgan tot de rol, die het lekensysteem bij de consumptiegeneigdheld speelt. 


\section{HOTEN BH ROOFDSNUK ?}

1) Get is niet bekend, hoeveel patienten aile opgaven door de specialist behandeld te worden, woor $20^{\prime} \mathrm{m}$ behandeling telkens en verwijsbrief bij de huigartis noten halen. Men mag echter aannerwen, dat dat voox door pecialisten voorgeschreven en witgevoerde controles aerdex ultzondering dan regel zal zifn.

2) Hitebil met worden opgemerkt, dat non-parametrische correlatiecoufficlerten gevoelig zifn voor gelijke warmemingen ("ties"). Dorordat met ratime het aintal huisartsconsulten vele "ties" bevat, is ait beeld vermoedeljjk lets vertekend. voorts is voor gepartialiseerde rangcorrelaties het significantieniveau niet bekend; signiflicarte nulde-orde correlaties $(p<.05)$ zijn in tabel 7.4. onkadera.

3) Volledigheidshine is alt gegeven ook voor elke patientencategorie afzonderlifk berekend. Dok al verschillen deze noch wat de irhoud van consumptegeneigdheid noch wat. de intensiteit ervan betreft van elkax, is het toch niet geheri ultgesloten, dat de samenhang tussen geneigdheich en feiteliyke consumptie wel verschilt. Noch de richtingen van de verbanden noch het totalbeeld van de ultkomsten geven evenwell wezenlijke verschilien op dit punt te zlen. (bijlage El

4) Het argument woox toepassing van parametrische technieken op ordinale in plaats van op interval-gegevens luidt over het algemeen, dat door een wolloende grote $\mathrm{N}$ het intervalkaxakter wordt benadexd.

5) In dit werband alj eraan hexinnexd, dat de respondenten 0.m. op leettijd en geslacht geselecteerd zijn. Ten aanzien wan de owerige persoonskenmexken verschilien de patientencategorieen niet significant van elkaar. (ale bijlage 1 )

6) Partialisering wijst uit, dat deze samenhang behowden blijft als voar opleiding wordt gecontroleerd.

7) Dlt ligt mede ten grondslag aan de gehanteerde stxess-theorie, zie Dirken, p. $17-21$, p. $36-44$ en vaoral p. 118.

8) Het is Dirken niet gelukt on na te gaan of de V.O.E.G. m.b.t. een algemene klaagneiging vertekenend is, zie Dixken, p. 170-172. 
Hoofdstuk 6. Samenvating

In dit deel stond de consumptiegeneigdheid central. Wij hebben ait verschijnsel op een bepalde wijze geoperationaliseerd en onze overwegingen daarbij uiteengezet. Wij zullen de voornaamste overwegingen hier nogmaals noemen.

In de eerste plaats vatten wij consumptiegeneigdheid saciaal-psychologisch op en plaatsen het tegen de achtergrond van theorieën over attituden e.d. Daarbij werd zoveel mogelijk rekening gehouden met de kritiek die deze theoriedn over het algemeen ondervinden. Onze werkdefinitie onschrijftconsumptiegeneigaheid als een geheel van opvattingen, attituden en gedragsintenties dat met medische consumptie te maken heeft.

Bij de operationalisering daarvan staat voorop, dat het ons on vrij globale opvattingen etc. gaat en niet om meer specifleke dimensies daarbinnen. Het was van belang om na te gaan, of de inhoud van de consumptiegeneigdheidscomponenten door de aard van de aandoening werd bepald. Als dit het geval is, dan moeten wij consumptiegeneigdheid immers per patientencategorie bezien. Wij kunnen dan niet van "de consumptiegeneigdheid in dit onderzoek" spreken. Onze analyse wees echter uit, dat de antwoordpatronen van hartinfarctpatienten, diabetici en psoxiasispatienten in het vraaggesprek niet wezenlijk van elkaar verschilden.

Wij hebben uiteindelijk vijf consumptieqeneigdheidscomponenten onderscheiden:

1. vertrouwen in de medische zarg (veel $\rightarrow$ weinig)

2. attituden t.a.v. de eigen arts (positief + negatief)

3. opvattingen over ziekte (onprofessioneel + professio-

4. attituden t.a.v. de eigen aandoening: neel) zilektebeleving (slecht $*$ goed)

5. gedragsintentie m.b.t. medische consumptie (sterk + gering)

Daarbij zagen wij er bewust vanaf, om deze componenten tot cen variabele samen te voegen of om veronderstelitingen te formulexen over de wijze warop zij bij de belnvloeding van medische consumptie zouden samenhangen. Noch de onderzoeksresultaten van anderer, noch de in dit onderzoek gevonden samemhangen 
tussen de componenten gaver woor zo"n werkwije zinvolie aanwitungen.

In hoofdstuk 7 hebben wij enkele eerder geformuleerde hypotheser getoetst (zie hoofdstuk 3 , paragraaf 3 , hypothesen 1.1., 1.2. en 2.). Daarbij kwamen wj tot de opmerkelijke conclusie, dat de patientencategoriean onderling niet verschillen in hun consumptiegenelgaheld. Hun scores op de afzonderlijke geneigaheidacomponenten verschilien zo weinig van elkaar, dat wij de hypothese 1.1. moeten verwerpen. Wij spreken nu dan ook niet langer van de consumptiegeneigdheid van hartinfarctpatienten, diabetici en psorlasispatiënten, max van de consumptiegeneigdheid van chronische patiënten.

ook de hypothese betreffende een afnemende consumptiegenelgdheld bij een langere zlekteduur rond geen steun in de onderzoeksresultaten (hypothese 1.2.). Patienten die langer dan vijf jaar weten, dat zij een chronische andoening hebben, zijn niet meer of minder tot medische consumptie geneiga, dan patienten die dat mindex lang weten.

In welke mate kan consumptiegenelgaheid nu feitelijke medilsche consumptie voorspellen (hypothese 2)? Deze vraag kwam in paragraf 7.3 . aan de orde. onder medische consumptie werd daar het aantal huisartscontacten begrepen, warbij eventueel voorgeschreven controleconsulten (statistisch) buiten beschouwing bleven (stapsgewijze regressie-analyse). Het bleek, dat bijna 21 van de variantie in de radpleegfrequentie doox de vijf genelgaheidscomponenten verkladrd kon worden. Daarbij leverden de attitude ten aanzien van de arts, de gearagsintentie en de ziektebeleving onafhankelijke, sigmificante bijaragen. De invloed van de opvattingen over ziekte en medische zorg was gexingex en niet significant. zlet men af van de voorgeschreven consulten, door alleen de vijf genelgaheidscomponenten in de analyse te betrekken, dan gtigt de verkladae variantie tot bijna 28 on neent de betekenis van de ziektebeleving aarbij auldelijk toe.

Al met al is dit een zeer buredigend resultad met betrekking tot de gedragsvoorspellende waarde van ons meetinstrument. 
Hoofdstuk 7 besteedie voorts aandacht an enkele samenhangen tussen consumptiegeneigdheid en persoonskenmerken (paragraaf 7.4.$)$. Deze samenhangen $z i j n$ zwak en hebben betrekking op de meer cognitieve componenten van geneigaheid - de opvattingen over ziekte en medische zorg en de gedragsintentie die allen met opleiding verband houden. Jongeren vertonen bovendien een minder sterke gedragsintentie dan ouderen. De overige bestudeerde persoonskemmerken (geslacht " urbanisatiegraad en burgerlujke staat) hangen opvallend genoeg met gén van de consumptiegeneigdheliscomponenten samen.

Alle resultaten tot nu toe geven aanleiding tot de conclusie, dat het bij de door ons geoperationaliseerde consumptiegeneigdheid om een relatief robuust meetinstrument gaat, dat vrij stabiele deelverschijnselen meet. Het instrument is duidelijk geschikt als gedragsvoorspeller van medische consumptie.

Tenslotte onderzochten wij nog enkele verbanden tussen consumptiegeneigaheid en twee daamee blijkens de literatuur verwante verschijnselen, nl. medische kennis en stress Igeindiceerd door middel van psycho-somatische klachten; V.O.E.G.).

Er zijn geringe aanwijzingen, dat veel specifieke medische kennis met een relatief geringe consumptiegeneigdheid en met weinig medische consumptie samengat, mar de verbanden zijn niet sterk. Veel medische kennis houdt wel duldelijk verband met weinig vertrouwen in de medische zorg.

De lezer, die geinteresseerd is in theorleën over "stress" en "coping behavior" zij verwezen naar de laatste paragraaf var hoofdstuk 7. Daarin komt naar voren, dat de mate waarin chronische patiënten erin slagen om hun socilale rol als patient te anvararden, van grote betekenis is voor de wijze warop zij omgaan met de aandoenung en de stress, die deze met zich meebrengt. Eerder stelden wij vast, dat respondenten die langer dan vijf jaar chronisch patiënt zijn, ju hun consumptlegeneigdheid niet verschilden wan respondenten, die dat minder lang zijn. Hiex blijkt evenwel, dat de samenhangen tussen consumptiegeneigdheidscomponenten onderiing, stress en de feitelijke medische consumptie wel degelijk veranderen, maarmate de zlekte langer durt. 
DEE L I I I

H E T L E K E N S Y S T E E M 
Hoofdstuk 9. Beschrijving van het lekennetwerk

\subsection{Inleiding}

In hoofdstuk 2 werd al gezegd, dat Feidson met het liekennetwerk een partieel of uniplex netwerk (Mitche11, 1969) op het oog heeft. De relaties in zo'n netwerk hebben betrekking op een bepaald onderwerp, in dit geval op ziekte en gezondheid. De omvang van het netwerk kan per persoon verschiliend $z i j n$. Binnen een netwerk zijn deelnetwerken te onderscheiden, die de aard van relaties tussen de leden typeren. De meest genoende deelnetwerken hebien betrekking op gezins- en familierelaties, op vrienden, Kennissen, buren en op collega's.

In dit hoofdstuk willen wij enkele kenmerken van het partiële netwerk van onze respondenten beschrijven. Daarbij gaat het om een algemeen overzicht, dat als achtergrond moet dienen bij de behandeling van onderzoekshypothesen betreffende het lekennetwerk in de hoofdstukken 10 en 11 hierna. Paragraaf 9.2. bevat globale gegevens over het partielle netwerk in $z$ 'n geheel. In paragraaf 9.3. komt het door ons meer in detall bestudeerde deel van het partiele netwerk aan de orde: de meestbetrokken lekenadviseurs. In paragraaf 9.4. worden tenslotte de belangrijkste bevindingen uit het voorgaande met de consumptilegeneigdheid van de patiënt in verband gebracht.

\subsection{De omvang var het lekennetwerk}

Wif hebben slechts enkele gegevens over het lekennetwerk als geheel verzameld en wel op de volgende wijze. De respondert is gewragd, wie ex allemal van weten, dat hij of $z$ li de aandoening in kwestie heeft. De vraag is per deelnetwerk gesteld en kon beantwoord worden met "bijna allen" (van hulsgenoten, familieleden, vrienden en kennissen, buren). "sommigen" of "bijna niemand". Wij onderschedden vier deelnetwerken, zodat in total 300 antwoorden werden verkregen. Tabel 9.1. geeft per deelnetwerk en voor alle deelnetwerken tezamen een overzicht van de onvang van het lekennetwerk. 
Tabel 9.1. Onvang var het dekensysteen fabrolute aantalleni

\begin{tabular}{|c|c|c|c|c|c|}
\hline & $\begin{array}{l}\text { huisge- } \\
\text { noten }\end{array}$ & $\begin{array}{l}\text { famile- } \\
\text { leden }\end{array}$ & $\begin{array}{l}\text { vrienden, } \\
\text { kennissen. }\end{array}$ & buren & $\begin{array}{l}\text { totaill } \\
\text { (perce })\end{array}$ \\
\hline bijna allen & 70 & 65 & 52 & 34 & 77 \\
\hline sominigen & 1 & 7 & 16 & 20 & 15 \\
\hline bljna nitemand & - & 2 & 5 & 16 & 8 \\
\hline n.v.t. & 4 & 1 & 2 & 5 & - \\
\hline totadi & 75 & 75 & 75 & 75 & $1288=100$ \\
\hline
\end{tabular}

Het merended van de mensen, warmee de respondenten omgaan weet blijkbaar, dat zij een bepaalde aandoening hebben. Daarbij tekent zich voor de deelnetwerken en bepalde prioriteit af: praktisch alle huisgenoten en vrij veel familieleden weten ervan. De vrienden en kennissen zijn ervar in mindere mate op de hoogte en de buren nemen wat dit betreft een latatste plats in. Vooral dit laatste ls tot op zekere hoogte opmerkelijk, omdat anderen vrij nauwe relaties tussen buren onderling warmamen. Van 195 (vrouwelijke) buren in Amsterdam oost verklaarde 78 , dat $21 j$ en hun buren elkaar wel helpen (Nauta, 1973). Knipscheer onderzocht wijf deelnetwerken van oudere mensen in Nujmegen op verschillende inhouden. Daaruit blijkt, dat kinderen en wrienden het belangrijkst en ardere familieleden en in het bijzonder broers en zussen het minst belangrijk zijn. Buren nemen wat dat betreft een tussenpasitie $i n . \mathbb{1}$ ) op het gebled van de hulpverlening bezetten $z i j$ zelfs en tweede plates ma de kinderen (knipscheer, 1980, p. 93). Voox onze respondenten zijn buren mogelijk minder belangrijk en In leder geval niet de meest aangewezen personen om met hen over de eigen gezondheld te praten. ${ }^{2)}$

wijn wat dat betreft nog verschllen tussen de drie patiêntencategorieên? Tabel 9.2. lat zien, dat de persoonlijke relaties van psoriasispatienten het minst op de hoogte zijn van de aandoening van hun "mede-netwerklid", gevolgd door de rellaties van diabetici. Het partiele netwerk van hartinfarctpatiënten is daarentegen nogal omvangrijk. 3) 
Tabel 9.2. Onvang van het lekensysteem naar patientencategorie (absolute aantallen)

\begin{tabular}{|c|c|c|c|c|}
\hline & $\mathrm{H}$ & $s$ & $p$ & $\begin{array}{l}\text { totaal } \\
\text { (pere.) }\end{array}$ \\
\hline Wijna allen & 87 & 76 & 5,8 & 77 \\
\hline sonmigen & 10 & 15 & 19 & 15 \\
\hline bijna niemand & 2 & 5 & 16 & 8 \\
\hline n.v.t. & 1 & 4 & 7 & - \\
\hline totaal & 100 & 100 & 100 & $(288=100)$ \\
\hline
\end{tabular}

op alt punt willen wij aan de resultaten uit hoofdstuk 4 herinmeren. Daaruit bleek, dat de door ons gehanteerde patientenopsporingsprocedure voor hartinfarctpatienten een over- en voor de overige twee categorieën een onderrapportage opleverde. Voorts bleek, dat hartinfarctpatiënten eerder tot deelname aan het eigenlijke onderzoek bereid waren, dan diabeticl. En tenslotte constatererden wij, dat psoriasispatiënten rainder "meest-betrokken" lekenadviseurs noemden dan de andere twee graepen.

Al met al tekent $z i c h$ een beeld af-waruit blijkt, dat het partiële netwerk wan hartinfarctpatiënten $0.9 \cdot$. verschillende criteria groter is, dan dat van diabetici en psoriasispatiënten. De verschillen tussen de laatste twee groepen zijn minder duideiljk mar wijzen erop, dat psoriasispatienten het minst omvangrijke lekennetwerk hebben. Hoe kan deze bewinding worden geinterpreteera?

Er zijn verschildende interpretaties denkbat. Mer kan wijzen op een typlsche persoonlijkheid van hartinfarctpatiériten (het "type A" "Friedman en Rosenman, 1969) of op het feit, dat zij relatief sociabel zijn (Van Dij1, 1978), Voorts is de aard van deze aandoening in hoge mate legltien (Giel, 1976). De ernst ervan worat door iedereen exkend. 
Dit laatste is bij dibetes niet altijd het geval. Wiet zelden wordt erop gereageerd net "... sulkerziekte, och, je spuit "Lets", houdt je aan een dieet en je wordt misschien wel hondera ir (Van dex Horst, 1980 , pag. 56). Dergelijke reacties kumren en diabeet weerhouden, om veel mensen in zijn ongeving over zijn aandoening in te lichten. Groen en De Ioos (1973, pag. 15) wijzen ex bovendien op, dat diabetes veelal gepaard gat met een toestand van "milde depressie", eenzaamheid en met het gevoel, door naste sleutelfiguren miet begrepen te worden.

En tenslotte: psoriasis is een aandoening, die heel vaak met schaamtegewolens gepaard gaat. De symptomen wekken bij anderen afkeer en bovendien ten onrechte de angst voor besmetting. Het kom dan ook voor, dat psoriasispatienten zich soclaal geisoleerd voelen (Van veen-viëtor, 1975, Musaph, 1977). De verschilien in netwexkonvang tussen de patiëntengroepen zullen bovendien samenhangen met de mate, warin de aandoening in kwestie over het algemeen lemands leven "behherst". ondex de door ons ondervraagde psoriasispatienten bevonden zich wadrschijnlijk weinig mensen, die deze aandoening hebben in de mate warin Van pelt (1976) haar beschrijft. Ook de gegevens van hun artsen wijzen erop, dat de psoriasis voor de doox ons onderzochte groep over het algemeen niet erg ingrijpend is. Een hartinfarct is daarentegen op zichzelf al een ingrijpende gebeurtenis, warvan de sociale ongeving van de patient meestal al snel op de hoogte is. De aan dit onderzoek deelnemende diabetici nemen wat dit betreft vermoedelijk een tussenpositie in.

zonder daarvoor meer precieze oorzaken te kunnen aangeven Is het - gezlen het voorgaande - annemelijk, dat de omvang van lekennetwerken werschilt, ahankelijk van de gezondheldstoestand van reen of meer van! de leden. Dat kan voor onderzoek met het "Lay teferral system" als onderwerp wan belang zijn. Ons onderzoek biedt geen nogelijkheld, om ook andere netwerkkemerken op verschilien tussen patientencategoriekn te bezien. Wij weter niet wie de netwerkleden precies $z \mathbf{j} n$, of zij elkarar kenner. of zij frequente wederzijase contacten onderhowden en of de deelnetwerken elkaar overlappen. Al deze zaken zijn voor de 
studie van lemands netwerk van belang. wij kunnen over de structuur van de onderzachte lekennetwerken an ook niet meex zeggen. Wij weten wel iets meer van de meest betrokken lekenadviseurs. Daarop gaan wij in de wollgenae paragraaf nader in.

\subsection{De meest betrokken lekenadviseurs: wile zijn dat?}

In hoofdstuk 4 werd al vermeld, dat de meest betrokken lekenadviseurs door de respondent zelf zijn aangewezen. In termen van de theorle van sociale netwerken gaat het hier om een deel van het partiële netwerk. De relaties binnen dit deel zijn wederkerig. Wij beschikken ower informatie, waarmee wij deze wederkerigheid op bepalde detailpunten kunnen toetsen. Naast zijn hier centraal gestelde inhoud (de aandoening en wat ermee samenhangt) heeft het retwerk warschijnlijk nog vele andere inhouden (bijv. "intimiteit", "hulpverlening"). Onze uitgangspunten impliceren immers, dat de leden tot de primaixe sociale relaties van de patiënt behoren (zie hoofdstuk 2 paragraaf 3.4.). Maar wie zijn het?

In hoofdstuk 4 werd daarover al iets gezegd. Tabel 9.3.. geeft de daar genoemde gegevens per patientencategorie weer.

Tabe 1 9.3. De meest-betrokken lekenadwiseus nar aard van hun relatie met de patient-respondent en naar patientencategoris labsoIute aantalien)

\begin{tabular}{lrrrr} 
& $\mathrm{H}$ & $\mathrm{S}$ & $\mathrm{P}$ & totad \\
\cline { 2 - 5 } partner & 22 & 19 & 21 & 62 \\
moeder & 2 & 4 & 2 & 8 \\
vader & 1 & 3 & 0 & 4 \\
(schoon) dochter & 9 & 7 & 4 & 20 \\
(schoon) zoon & 5 & 2 & 1 & 0 \\
overige familie & 3 & 5 & 2 & 10 \\
vaienden, buren & 2 & 2 & 1 & 5 \\
total aantal advi- & 44 & 42 & 31 & 117 \\
seurg genoemd & & & &
\end{tabular}

Het is duidelijk, dat het biex nader bestwdeerde lekennetwerk overwegend uit gezins- en farmilieleden bestaat. Buren en vrienden spelen daarin nauwelijks een rol fvergelijke Bruhn, 
1977). Partners zijn uiteraard het meest betrokken 165 respondenten zijn gehuw, zie verderop in deze paragraaty. maar het valt op, dat relatief veel dochters de rol van adviseuze vervullen. Dit komt avereen met de bevindingen van Van DoornJarssen (1971) en froland (1979), die erop wijzen, dat men voor advies bij problemen of voor psychosociale zorg in verband met ziekte mestal op gezins- of familieleden texugvalt. Booth en Babchuk constateerden, dat de volwassen dochter hierbij een belangrijke rol speelt (Booth en Babchuk, 1972). Er doen zich geen opmerkelijke verschilien tusser de patientencategorieẻn voor. 4)

44 Mannelitke en 31 vrouwelijke patiënt-respondenten hebben samen 40 manneljjke en 74 vrouwelijke lekenadviseurs aangewezen. ${ }^{5)}$ Het abtal bij dit onderzoek betrokken vrouwen is dus vrij groot. Maar alt is begrijpelijk, aangezien er meer mannelijke dan vrouwelijke patiënt-respondenten zijn en veel mensen hun partner als lekenadviseur noemden.

Tabe1 9.4. Aard varn de relatie tussen patient-respondent en lekenadviseur. naar geslacht van de patiënt (absolute aantallen)

partinam

ortar

kind

overe

ritemand

total

\begin{tabular}{|c|c|c|c|c|c|}
\hline \multicolumn{2}{|c|}{ man } & \multicolumn{2}{|l|}{ yrouw } & \multicolumn{2}{|l|}{ totad } \\
\hline 39 & & 23 & & 62 & \\
\hline 7 & & I & & 12 & \\
\hline 12 & 25 & 16 & 30 & 28 & 55 \\
\hline 6 & & 9 & & 153 & \\
\hline 24 & & 9 & & 33 & \\
\hline 98 & & 62 & & 150 & \\
\hline$x^{2}=$ & 1 is & os & & & \\
\hline
\end{tabular}

In tabel 9.4. valt op, dat vrowwen totaal relatief meer niet-partners, wooral meer kinderen als lekenadviseurs moemen dan mannen en dat mannem wat vaker hun partner of helemaal niemand noemen dan vrouwen. De bevinding van Bott (1957) "women have relatives. men have friends" gaat in dit geval voor de mannen niet op: gevraagd naar meest-betrokken lekenadviseurs in verband met hun aandoening wijzen zij die vriencen in ieder geval niet aan. 
Aan ons onderzoek namen slechts vier alleenstaanden deel, waardoor nauwelijks is na te gaan of deze bijzonder kwetsbaar $2 j j n$, omat $2 i j$ voor eventuele steun bij problemen rondom hun aandoening niet op gezinsleden kwanen terugvallen (Van DoormJanssen, 1971 , pag. 7). Van de 31 personen die geen tweede betrokkene konden noemen (waaronder twee personen die helemal niemand noemden) is er echter slechts efn alleenstaande (gescheiden), de anderen leven allen in gezinsverband. De overige drie alleenstaanden noemden een kind of ander familielid als lekenadviseurs.

Tenslotte willen wij nog iets zeggen over de opleiding, die de patient-respondenten genoten hebben en hun relatie met de lekenadviseurs. Tabel 9.5. geeft daarvan een indruk.

Tabe1 9.5. Opleiding van patient-respondenten nar ard van de relatie met hun lekenadviseurs labsolute aantallem

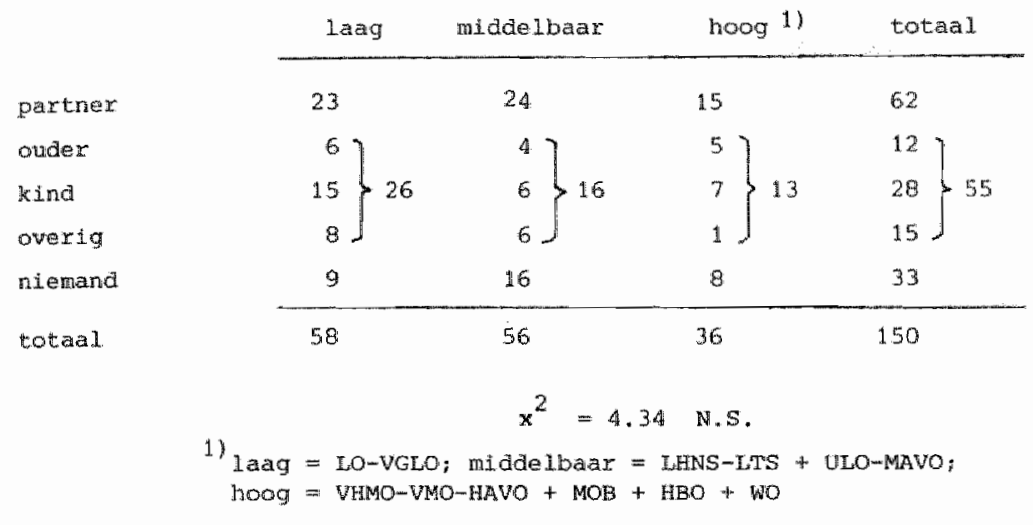

ook al verschilien de totalultkonsten naar opleidingsniveau niet significant van elkaar, het valt wel op, dat lager opgeleiden wat vaker hun kinderen als adviseurs noemen "dan hoger opgeleiden. Dit komt overeen met de bevindingen van Finlayson (1976). Vexder valt op, dat lager opgeleiden wat meax lekenadviseurs nomen dan hoger en middelbaar opgeledden. Dit is niet in overeenstemming met de meer algemene bevinding, dat lagere klassen minder informele hulp bij allerlel problemen krijgen dan hogere klassen (M11ler, 1973, Finlayson, 1976, Sacial en Cultureel Rapport, 1980/. Dit is wellicht toe te 
schrijwen ain het fest, atat het hier om het aantal betrokken lekenadwiseurs gat, zondex dat datibif in eerste instantie sprake is vam hulp, die deze mensen verlenen.

\subsection{De omvang van het partiele netwerk en de} consumptlegenelgdheid van de patienten

In paragraaf 9.2 . bleek de omvang van het lekennetwerk ge. deeltelijk samen te hangen met de ara var de aandoening. Wij veronderstelden, dat deze bevinding samenhangt met specifieke kenmerken van de hier bestudeerde chronische ziekten en met de mate warin iemands gezonaheidstoestand de dagelijkse gang van zaken in zijn omgeving beinvloedt, zodat anderen ex min of meen vanzelf bij betrokken raken. In hoofdstuk 7 werd duldelijk, dat de patientengroepen in hun consumptiegeneigdheid niet van elkaa verschilien. Whj wilen deze bevindingen nu met elkaar in verband brengen en vragen ons af: bestaan er samenhangen tusser de omvang van het lekennetwerk en de consumptiegeneligheid van de patiënt?

Wij hebben dit punt op drie werschillende manieren onderzocht. In de eerste plats berekenden wij de correlaties tussen geneigaheidscomponenten en de onvang van het partielle netwerk. Voor dit laatste sommeerden wij per individu de antwoorden met betrekking tot de vier deelnetwerken, waxbij "bijna allen" = 3 , "somigen" = 2 en "bij.jna niemand" = 1 werd gescoora. Tabel 9.6. wijst uit, dat geen van de onderachte samenhangen significant is.

Tabel 9.6. Samenhangen tussen de anvang van het partide netwerk en de vijif geneigdheidscomponenter (rho's, allen $\mathrm{N} . \mathrm{S.}$ )

$1 \quad 2 \quad 3 \quad 4 \quad 5$

Omving netwerk

Klein groot:

$\begin{array}{ccccc}1 & 2 & 3 & 4 & 5 \\ -.16 & -.10 & -.06 & -.10 & -.15\end{array}$

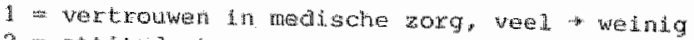

$2 \Rightarrow$ attitude t.a.v. arts, positief $\rightarrow$ megatief

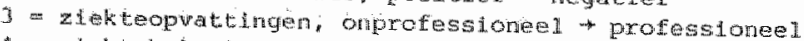

$4=2$ wektobelewhin, slecht t goed

5 - gedragsintentiv, sterk $\rightarrow$ gexing
} 
Vier van de vijf correlatiecoëficienten wijzen wel in de richting wan een samenhang tussen een groot netwerk en weel consumptiegenelgdheid. Alleen de component, die in hoofdstuk 7 , paragraaf 7.3 het minst belangrijk bleek als determant voor medische consumptie, doet dat niet (ziekteopwattingen).

In de tweede plats hebben wij aandacht besteed aan een speciale categorie patiënten binnen onze onderzoeksgroep, $n j$. aan personen die nar aanleiding var hun andoening contact hebben gekregen met medepatiënten. Deze medepatiënten vormen een apart deelnetwerk, warin meer dan in de andere deelnetwerken de aard van de aandoening centraal staat. Op verschlllende platusen is gebleken, dat hulp verleend door lotgenoten verlichting kan bieden voor de wijze warop patienten hun ziekte ervaren (van Harberden en Lafaille, 1978, Bremer-Schulte, 1980). Hier wragen wij ons af, of de ongang met medepatiënten met lemands consumptiegeneigdheid samenlangt.

Weertien pexsonen in onze onderzoeksgroep onderhouden contact met medepatiënten. Daarvan hebben er zeven een hartjnfarct gehad, vier zijn diabeet en drie psorlasispatient. Wij vergelijken de vijf geneigaheldscomponenten van deze veertien met die var de overige respondenten (Mann-Whitney u-toets, tweezijdigl. De enige significante uitslag betreft de ziektebeleving: contact met medepatiënten komt voor bij personen, die een relatief siechte ziektebeleving hebben $(z=2.63, p<.009)$.

In de derde plats stelden wij de vraag: verschilien mensen met geen of slechts én lekenadvisenr in consumptiegenejgaheid wan de overigen? ook op dit punt vinden wij slechts Eên significante uitkomst: patiënten met twee lekenadviseurs hebben - tergeleken net de overigen - een slechte ziektebeleving (Mann-Whitney u-toets, tweezijdig: $z=3.09, p<.002$ ). Ten aanzien van de andere geneigdheldscomponenten verschilien $21 j$ niet.

Deze uitkomsten zijn - gezien het poorgaande - allesins plausibel en weerleggen onze verondersteling niet: een aandoening, die de dagelijkse gang van zaken sterk belnvloedt (waardoor ex vele mensen bij betrokkeri rakenl gaat - zo mag men aannemen - gepaard met zorgen over die ziekte, met het gevoel. echt ziek te zijn, kortom: met een slechte ziektebeleving. 
Wij watter ae belangrijkste bevindingen wit de beschrij*ng wan lekennetwerkkenmerken hier nogmals puntsgewijs gamen.

1. De omvang yan het lekennetwerk verschilt per patiêntencategorle: namate de andoening ernstiger is, is het lekenrietwerk groter.

2. Narmate de andoening exnstiger is, wijzen de patientrespondenten meer alrect betrokken lekenadviseurs aan (significant alleen voar psortasispatiunten in vergelijking riset de andex twee groepen).

3. Ex is een zwake anwljzing voox een samenhang tussen een groot netwerk en een relatief sterke consumptiegeneigaheid (significant telkens roor de belangrijkste geneigaheidscomponent, al. de ziektebeleving).

De vraag is nu, welke betekenis aan deze bevindingen kan worden toegekend in het licht wan onze onderzoekshypothesen betreffende de invloed van lekenadviseurs op lemands consumptiegeneigdheid. Op deze vraag komen wij in hoofastuk 11 terug. Eerst besteden wij aandacht an de meer precieze irhoud van de door ons bestudeerde lekentetwerken.

NOTEN BIJ HOOFWSTUK 9

1) Deze wolgorde geldt ook voor de relatle-inhoud "intimiteit".

2) Dit blijkt ook wit het geringe antal buren, dat door de respondent als lekenadiseur werd angewezen. (z je hoofastuk 4 en paragraf 9.3 . hiverra.)

3) Deze volgorde geldt woor alle ondexschelden deelnetwerken.

4) Marbiy kan worden aangetekerid, dat hartinfarctpatienten relatief ouder zijh dan diabetici (2ie tabel 4.4.2, wardoor de eersten waxschijhlifk mer kinderen, de tweden meer oudars noemen.

5) Van de drie (ulteindelijk niet-ondervraagde) adviseurs is het geslacht nise bekend. 
Hoofdstuk 10. De consumptiegeneigdheid in lekennetwerken

\subsection{Operationaliseringen}

In hoofastuk 6 werd beschreven hoe wij werschillende componenten van consumptiegeneigdheid van patièn-respondenten operationaliseerden. Voor de bij dit onderzoek betrokken lekenadviseurs werden vergelijkbare variabelen bepaald, en wel op de volgende wijze.

Een groot deel van de vragenlijst voor lekenadviseurs is identiek aan die voor patiënt-respondenten. Daardoor konden hun opvattingen over medische zorg en over ziekte op dezelfide wijze worden samengesteld als voor patiënt-respondenten. Hetzelfde geldt voor de mate waarin men met bepalde klacten of lichamelijke verschijnselen de dokter zou consulteren (gedragsintentie). Voor de operationalisering van deze variabelen verwijzen wij naar paragrafen 3.2., 3.4. en 3.6. van hoofastuk 6 . Met opzet is gekozen voor identieke schallvorming, waarbij de vraag naar de schaalbarheid binnen de categorie lekenadviseurs afzonderlijk buiten beschouwing bleef. Wij zijn immers niet zo zeer geinteresseerd in de "eigen" consumptiegeneigdheid van lekenadviseurs, mar veeleer in de invloed van de lekenadviseurs op de geneigdheid van de patiënten om hun arts te raadplegen.

Dit uitgangspunt is tot op zekere hoogte eenzijdig. Daarin blijft immers de vraag, of lekenadviseurs zelf ziek zijn en er ten aanzien van hun eventuele aandoeningen en artsen bepalde denkbeelden op na houden buiten beschouwing. Afgezien van de problemen, die deze vraag voor de opbouw en inhoud van de enquete had betekend, is het antwoord daarop voor onze probleemstelling ook niet primair van belang. Dit, ondat wij leden van verm schillende lekennetwerken bestuderen. Deze lekennetwerken bestaan mede omdat een 1 id ervan en chronische aandoenting heeft. Alle leden van het lekennetwerk hebber en bepalde geneigdheld, die de andoening in kwestie en de arts die deze behandelt tot "object" heeft. De opvattingen en attituden wan netwerkleden moeten daarom op dezelfde attitudeobjieten betrekking hebben.

De consumptiegeneigaheidscomponenten die betrekking hebben op de aandoening van de persoon in kwestie worden voor leken- 
adviseurs dan ook per definitie op andere wijze samengesteld dan voor patient-respondenten. Het gat om attituaen ale deze menten ex ten aanzien van äe ziekte wan de patiënt en ten aanziden van diens arts op nahouden.

speelt de aandoening van de patient een belangrijke rol voor with of haar lekenadviseurs? om hierin enig inzicht te krijgen werden in het gesprek met de lekenadviseurs verschilien de vragen gesteld nar de wijze warop hij of zij het beleeft, om nauw bij lemand met een chronische aandoening betrokken te zijn. Het correlatiepatroon van de antwoorden darop wees uit, dat de volgende drie variabelen onderling samenhangen en na sommering een indicator kunner vormen voor de attitude van de lekenadviseur ten aanzien van de ziekte van de pätiént (bijlage 10y:

- Erequentie warmee de lekenadviseur zich ovex de aandoening ongerust makt

- frequentie wamee men zelf problemen ondervindt, doordat de persoon een hartinfarct gehad heeft resp. diabeet of psoriasis-patiente is

- mate waarin men het woor zichzelf lastig vindt, dat de patient-respondent die andoening heeft.

Wij noemen deze component, net als bij de patiënten, "ziektebeleving", wetende cat met ziekte in dit geval het hartinfarct, de suikerziekte of de psoriasis van de patient-respondenter bedoeld is.

Tenslotte de operationalisering van de attitude ten aanzien van de de patiënt behandelende arts. Hebber de lekenadviseurs wel een oordeel over de wijze warap deze de patient voor het hartinfarct, diabetes regp. psoriasis behandelt? Damaar gevragd gaven zeven eerstgenoende en zes als tweede genoende lekenadviseurs te kennen "het echt riet te weten". Voor de overigen worde de bij deze vraag tot uitaruking gebrachte (an) tevredenheld ${ }^{11}$ met de arts opgevat als indicatox voor de geneigaheidscomponent, die wij kortweg "tevredenheid met de arts" noemen.

Wij hebben nu vijf indicatoren voox de consumptiegeneigdheld van lekenaduseurs, aie vergelijkbatar zijn met de vijf geneigaheidscomponenten van de patiënten. 2) voor het gemak zullen wij in het vervolg spreken van de constimptiegeneigaheid (scompo- 
enten var de lekenadwiseurs, zonder er telkens op te wijzen, dat deze voor wat het evaluatieve deel betreft gerelateerd is aan de aandoening en behandeling van de patient-respondenter.

\subsection{Lekenadviseurs van de dxie patièntencategorię̈n en hun consumptiegeneigdheld}

In hoofdstuk 7, paragraaf 7.3. werd onderzocht, of de patiëntcategorieër in consumptiegeneigaheld verschilien. Dat bleek tegen de verwachting in niet het geval te zijn. Hier is de vrag aan de orde of de lekenadviseurs van de drie patiëntencategorieen in verschillende mate tot medische consumptie geneigd $z i j n$, en zo ja, of deze verschilien interpretecrbax $z$ ijn tegen de achtergrond van de ard van de andoeningen. Daamee gaan wj in op de hypothese, dat llekenadviseurs van hartinfarctpatiënten de sterkste en die van psoriasispatienten de geringste geneigdheid vertonen en dat die van diabetici wat dit betreft een tussenpositie innemen (wergelijke hoofdstuk 3 * paragraaf 3. , hypothese 3.1 .1 .

De werkwijze is overeenkomstig die gevolgd in paragraaf 7.3. Tabe1 10.1. vat de resultaten van tien eenweg-variantieamalyses samen, waarbij de vijf geneigdheidscomponemter van de twee lekenadviseurs criterium-variabelen zijn en telkens voor de patïëntencategorieën op verschillen in variantie worden bezien.

Evermin als de patiënten zelf verschillen hun lekenadviseurs per patiëntencategorie in de mate warin $z i j$ consumptiegeneigd zijn, met een uitzondering: de het meest bij de andoening betrokkene (dat wil zeggen, de eerstgenoemde) lekenadviseurs verschillen signiticant in de wijze warop zij de arandoening van de patient beleven. Daarbij is de beleving van de adviseurs van hartpatienten het slechtst, die van psoxiasispatiënten het best. De ziektebeleving van sulkerpatiëntenadviseurs neent een tussenpositie in. Wij merken op, dat deze volgorde overeenkomt met de volgorde, die bil pa'ienten werd vastgesteld, die dar echter geen significante verschillen aan het licht bracht. voorts merken wij op, dat zich deze volgorde ook bij de tweede genoemde lekenadviseurs voorabet, maar ook 


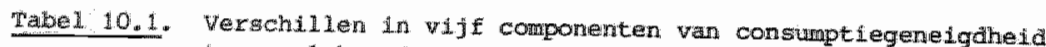
twissen lekenadwigeurs var hartinfaret- (W), suiker- (S) en psoxiasispatienter (P) (renweg-variantie-analyse)

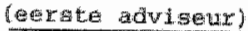

1. vertrowtren in medische worg (vee 1 tweinig)

totida I
B
5
$\mathrm{P}$

2. attitude ta. v. arts (positue $\rightarrow$ megateief)

totaal
$\mathrm{E}$
$\mathrm{P}$

3. opvatingen over ziekte (onprof * profession.)

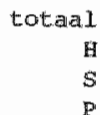

4. ziektebeleving

(shecht $\rightarrow$ goed)
37,8

37,0

37,8

38,8

9,6

8,6

9.7

10,6

42,5

$4,3,3$

42,8

41,3
$3,9 \quad 0.04$ 2,8 N.S.

3,9

5. gearagsintentie (sterk $\rightarrow$ gering)

37,0

37,0

38,10

37,0

2,6

2,6

2,7

2,6

1,2

其, 2

ii:, 3

1,4

6,7
10,0

8,6

10,2

1,2

2,8

3,0

2,8

2,1

3.37

$p<.05$

$6,2 \quad 0.49$

5,9 N. 5 .

0.85

N. S.

5

P


vervolg tabe1 10.1 .

(theede adviseuxy

gemidalde meaban s.t. $\mathrm{f}^{\mathrm{a}}$

1. vertrowwen in medische

zorg (veel weinig)

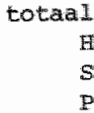

2. atcitude t.a.W. axts

(positief $\rightarrow$ negatief)

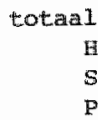

3. opwattingen ovex ziekte (omprof. trofession.)

totala 1
I
P

4. zỉektebeleving

(slecht - goed)

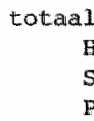

5. gedragsintentie

(sterk + gering)

totaal
$\mathrm{H}$
5
$\mathrm{P}$

39,3

39,6

38,6

39,8

10,0

9,3

10,3

11,1
18.0
19.0
15.0
15.0

4,4

$4,2 \quad 1,29$

4,0 N.S.

5,4
3,0

3,1

3,1

2,8
2,9

3,0

3,0

2,3

38,0

38,0

37,0

39,0
0.9

$1,1 \quad 0,85$

0,7 N.S.

1,3 
zidktebeleving significant verschilien. Dat zou er immers op kumen wijzen, dat deze adviseurs de aandoening van de patiênt respondent als het ware nog intenser beleven, dan de pationter aelf. ${ }^{3 !}$ Wij komen hierop nog terug.

\subsection{Consuraptiegeneigdheid van patienten en hun lekenadviseur}

In paragraaf 10.2. werd de consumptiegenelgdheid van groe pen lekenadviseurs bestudeerd. Onze problemsteling richt zic echter op de samenhang tussen de consumptiegeneigdheid van de patiënt-respondenten en zijn lekenadviseur(s). In deze paragrata gaan wij op deze samenhang in. De analyse wordt hier dan ook op individueel niveau uitgevoerd $(\mathrm{N}=72) .4)$

voordat wij ons met deze samenhang gaan bezig houden, moe wel eerst bedacht worden, dat onderlinge beinvloeding van pathenten en lekenadviseurs tijdens het interview opgetreden kam zijn in gevallen, warin gesprekken niet zonder anwezigheja wan anderen gevoerd konden worden. Ondanks instructies hierovel was het voor de enquetrices niet altijd mogelijk, om het inter. view onder viex ogen af te nemen. Uitgebreide rapportage van de enquetrices leverde de volgende informatie ovex de gesprekssituaties (tabel 10.2.).

rabel 10.2. Gesprekssituatides tijoens de interviews (absolute antallem) Gesprek gevoerd met

\begin{tabular}{|c|c|c|c|c|}
\hline \multirow{6}{*}{$\begin{array}{l}\text { daarbij was } \\
\text { de onder- } \\
\text { vraagde }\end{array}$} & & $\begin{array}{l}\text { patient } \\
\text { respondent }\end{array}$ & $\begin{array}{c}\text { eerste leker- } \\
\text { adviseur }\end{array}$ & $\begin{array}{l}\text { tweede leken } \\
\text { adviseur }\end{array}$ \\
\hline & alleen & 50 & 42 & 25 \\
\hline & gedeeltedijos alleen & 6 & 2 & 1 \\
\hline & nitet alleen ${ }^{2}$ ) & 17 & 25 & 12 \\
\hline & $\begin{array}{l}\text { geen informatice, } \\
\text { geen lekenadviseur }\end{array}$ & 2 & 6 & 37 \\
\hline & totad & 75 & 75 & 75 \\
\hline
\end{tabular}

1) niet gedurende het hele gesprek en/of wel iemand aanwezig. mak zonder dat deze, volgens het oordeel van de enguetrice, op het gesprek lette of daarop invloed uitoefende.

2) d.w.2. meestal in anwezigheid van een lid van het lekennetwerk. 
Wanneer gegevens wan patiënt-respondenten met ale van hun lekenadviseurs vergeleken worden, zullen wij hiermee rekening houden door voor een eventuele invloed van de gesprekssituatie te corrigeren. Voor de vergeljjking van genelgdheldscomponenten verwachten zij daarvan evenwel geen sterke invloed, ondat alle vijf componenten elk weer uit verschillende variabelen werden samengesteld. Het is niet waarschijnlijk, dat een lekenadviseur alle antwoorden "in de geest" van de patiënt-respondent kan of zal. greven.

On deze verwachting te kunnen staven zijn in onderstaande correlatiematrix (tabel 10.3.) niet alleen nulde-orde correlaties (Kendall"s, eerste regel) tussen geneigdheidsaspecten van patiënten en lekenadviseurs, maar ook partiële coëfficiënten aangegeven (tweede en derde regel, zie toelichting bij de tabel)

Tabel 10.3. Correlaties (Kendall) tussen geneigaheidscomponenten van patienten en hun lekenadviseurs 1 )

patiënt-

respondemt

1. vertrowwen .33 in medische .33 zorg .33

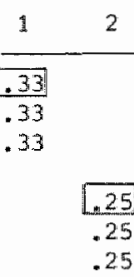

3. ziekteopvattingen

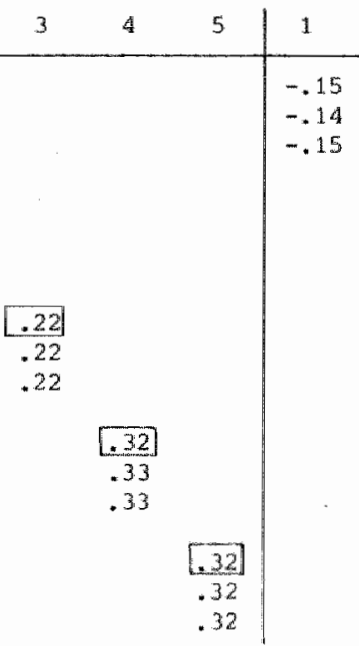

$2 \quad 3 \quad 4 \quad 5$

2. tovrecenheid toet arts \begin{tabular}{rrr}
\hline .22 & \\
.22 & \\
.22 & \\
& \\
& .32 \\
& .33 \\
& .33 & \\
& & .32 \\
& & .32 \\
& .32
\end{tabular}

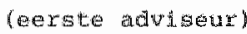

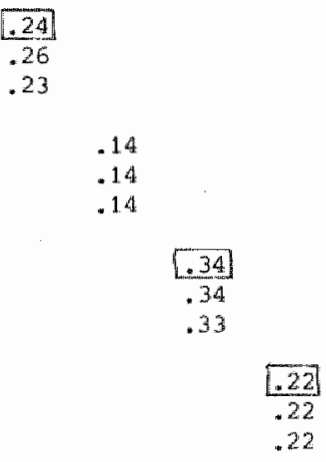

(tweede adviseur)

1) eerste regel: nulde orde (omkaderd - significant bij $p<.005$ ) tweede regel: gecontroleexd voor gesprekssituatie patidnt dexde regel : gecontroleerd voor gespreksisituatie lekenadviseur signilicantieniveau niet bekend, reden waarom alleen de eisste regel omkaderingen bevat. 
De correlaties laten er gen twifiel over bestaan: de consumptiegenelgdheid van de patient-respondent lijkt sterk op die van zhjn lekenadwiseurs. De personen in de nabije ongeving van de patient-respondenten hebben een damee zeer duddelijk vergelijkbare mate van geneigdheid tot medische consumptie. Deze overeensteming in attituden en denkbeelden komt verder niet voort uit de interviewsituatle: deze heeft daarop praktisch geen invloed gehad.

Alle geneigdheidscompomenten van patient-respondenten correlemen significant met de vergelijkbare opvattingen, attituden en gedragsutenties van de eerste lekenadviseur. De overeensteming tusgen patienten en tweede lekenadvisenr is geringer: in twee gevalien zijn de correlaties nlet significant, de zorgopvattingen cormeleren daarbij zelis negatief. "Mar het blijkt, dat julst componenten die de medische consumptie het meest beinvloeden (2ie hoofastik 7), mI. de attituden en de gearagsintentie, de hoogste correlaties opleveren. Alleen in de minder belangrijke opvattingen stemen patient en tweede lekenadviseur niet overeen.

Hiemee kumen wij concluderem, dat ex een redelijke overeensteming in consumptiegeneigdheid bestaat tussen patienten en hun lekenadviseurs. Dat neemt overigens niet weg, dat er ook lekennetwerken zijn aan te wijzen, warin minder of geen overeensteming op dit punt bestaat. Daarop gat de volgende paragraaf verder in.

kan men nu beweren, dat consumptiegeneigdheld in feite geen individueel kenmerk is, doch veeleer een kemmerk van een lekennetwerk? Om hierop een antword te geven, moet eerst worden nagegaan in welke mate lekenadviseurs onderling in hun consumptiegeneigdheld overeenkomen. Tabel 10.4. geeft exn - ook weer voor de gesprekssituatie gecorrigeerd - inzicht.

Het 1 s opvallend, dat de overeensteming tussen de eerste en de tweede lekenadviseur ten dele zelfs nog groter is, dan die tussen patiknt-respondent en lekenadviseurs. Dit houdt mogelijk verband met het felt, dat en combinatie van een echtgeno(o)t (e) als eexte en een kind als tweede lekenadviseur vriy veel vookkomt (in 20 van de 39 gevallen). Men kan zich voorstellen dat de partner-lekenadviseur als ouder het kind 
Tabe1 10.4. Correlaties (kendall's) tussen geneigaheidscomponenten van lekenadviseurs 1 )

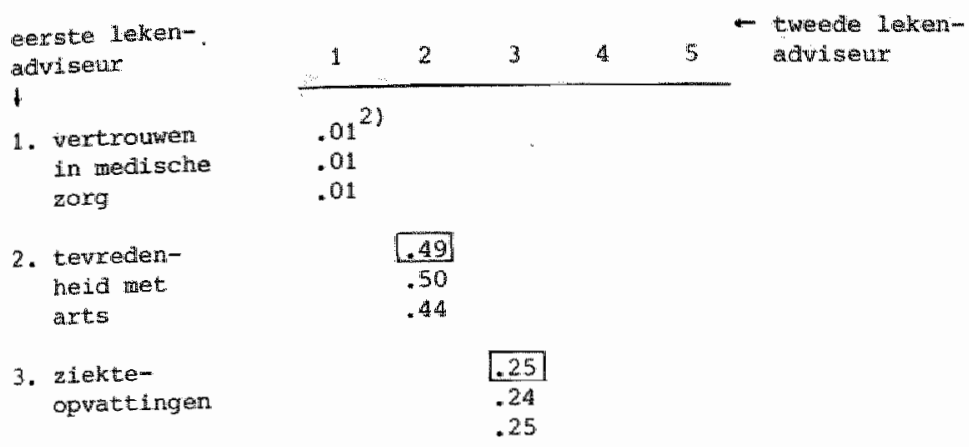
4. ziektebe- leving
53
.54
.53

5. gedrags

intentile

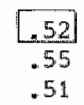

1) zie noot 1) bij tabel 10.3

2) zie noot 5 bij alt hoofdstuk

nogal sterk belnvloedt in zijn attituden en opvattingen ten aanzien van de aandoening van de andere ouder. Dit siuit aan bij de bevindingen van Smits. Hij concludeert dat ouders een sterke invloed hebben op de mate warin kinderen gezondheidsstoornissen aan de huisarts presenteren. Daarbij speelt onder andere het ongaan met (elkaars) gezondheidssoornissen en de beleving ervan een belangrijke rol (smits, 1978, p. 89).

De resulaten uit deze paragraf rechtvaardigen het, de consumptlegeneigdheid als kenmerk van het onderzochte lekennetwerk te beschouwen. Dit is ook af te leiden ult tabel 10.5., warin de overeensteming in genelgdheldscomponenten voor het lekensysteem als geheel is weergegeven door middel wan Kendall' concordantie-coëficiënt (siegel, 1956).

Met andere woorden: personen, die elkaar bij gezondheldszaken raadgeven en helpen, hebben eenzelfde algemene neiging tot het inroepen wan medische hulp. Dit is een belangrijke conclusie. zij steunt onze onderzoekshypothese betreffende de on- 
Tabe 2 10.5. Wake varn overeenstemming in consumptegeneigaheid in lleken-

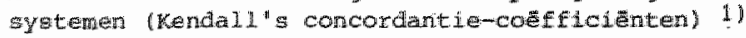

overeensteming met betrelking tot:

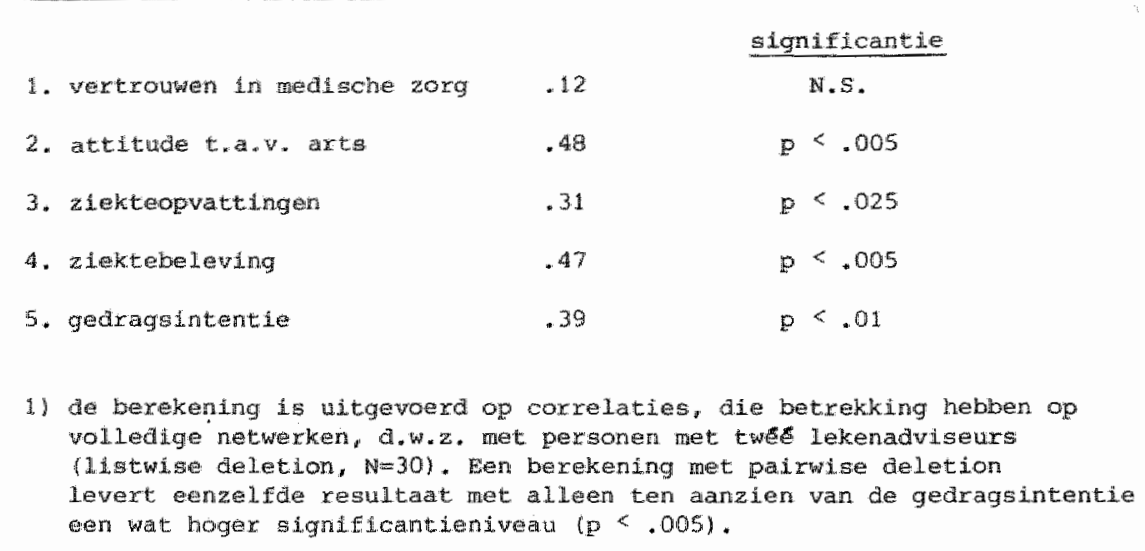

derlinge overeenkomsten in consumptiegeneigaheid binnen lekennetwerken (hypothese 3 algemeen).

Helaas valt de vraag, of de patient zijn lekenadviseurs beinvloedt dan wel de lekenadviseurs de patient met onze gegevens niet te beantwoorden. Hiex wreekt zich het eerder gesignaleexde nadeel van een informatieverzaneling op een tijdstip. wij moeten volstaan met het vemoeden, dat hierbij van een wisselwerking sprake zal zijn.

\subsection{Homogene en heterogene lekennetwerken}

zoals gezega: de overeensteming in consumptiegeneigaheid tussen netwerkleden, die tot ultarukking kont in de relatief hoge correlaties tussen de wariabelen, die die geneigdheid indiceren, verhult tot op wekere hoogte, dat er ook netwerken. zi in warvan de leden minder eensgezimheid vertonen. Dit om twee redenen. Ten eerste: de correlaties zijn wel hoog en significant, maar toch ook weer niet zo hoog, dat van volledige overeanstemming gesproken kan worden. Ten tweede, en dat is belangrijker: wi $\$$ hebben hiervobr de mate van eensgezindheld per geneigdiedacomponent bezien, terwijl echte eensgezindheid natuurlijk pas blijkt, als men in meer dan etn attitude of opvatting overeenstemt. 
Wij hebben geprobeerd netwerken te identiticeren, die op het punt van zoveel mogelijk geneigaheidscomponenten gelijk gezind zija (vergelijke Nauta, 1973). Bininen deze homogene netwerken zijn netwerken an te wijzen met een bijzondar sterke consunptiegeneigdheld (idealiter: overeensteming met betrekking tot veel vertrouwen in de medische zorg, een positieve attitude ten aanzien van de arts, professionele ziekteopvattingen, een slechte ziektebeleving en een sterke gedragintentile) en als tegenhanger: netwerken met een bijzonder geringe consumptiegeneigdheid. Het identificeren van dit soort netwerken is in de praktijk echter verre van eenvoudig, omdat drie personen in vijif componenten overeen moeten stemmen, die elk meestal weer vele verschillende warden kumen aannenen. naar homogeniteit te rangschikken moeten dan ook enkele beslissingen worden genomen ten aanzien van de vraag: is deze combinatie van attituden nog homogeen te noemen of niet meer?

Er werden twee verschilliende indelingen ontworpen ${ }^{6 /}$; ae eerste is uitsluitend gebaseerd op overeenkomsten tussen patient en zijn eerste lekenadviseur $(\mathrm{N}=\max .72)$, de tweede houdt zoveel mogelijk rekening met denkbeelden var alle drie de leden van het netwerk $(\mathbb{N}=\max .39)$.

Tabel 10.6. laat deze twee classificaties apart voor de patientencategorieèn zien.

Tabel 10.6. Homogene en heterogene netwexken ten aanzien van hun consumptiegeneigaheld naax patientencategorie

(1) homogeniteit bij patient en eerste lekenadviseur

\begin{tabular}{rrrr} 
D & S & P & totaal $^{1)}$ \\
\hline 5 & 3 & 3 & 11 \\
10 & 17 & 14 & 41 \\
6 & 3 & 3 & 12 \\
\hline 21 & 23 & 20 & 64
\end{tabular}

totalal

eneigdheid

homogeen-ster

homogen-geringe geneigaheid

(2) homogeniteit bij patient en beide lekenadviseurs

homageen-sterke geneligdheid heterogeen

homogeen-geringe geneigdheid

total

\begin{tabular}{rrrr}
4 & 3 & 1 & 8 \\
8 & 8 & 4 & 20 \\
3 & 3 & 0 & 6 \\
\hline 15 & 14 & 5 & 34
\end{tabular}

1) missende informatie m.b.t. één of meer componenten: 9 resp. 5 
Het is opvallend, dat zich binnen de patientengroepen ongeveer dezelfde verdeling voordoet als voor de gehele graep. Dat geldt zelfs nog - woor zover na te gaan bij het geringe aantal netwerken per patientengroep - wanneer men de mate van ovexeensteming tussen alle netwexkleden in de beschouwing betrekt. Dasuit mag men afleiden, dat de ard var de aandoening niet bepalend is voor de homogenteit van denkbeelden binnen het lekennetwerk.

\section{NOTEN BIJ HOOFDSTUK 10}

1. De antwoordmogelijkheden waren gelijk aan die voor patienten bif de hilermee vergelijkbare vraag, nI. van "buitengewon tevreden" tot: "niet zo tevreden".

2) Trabel 10.1. geeft een overzicht van enkele statistische kenmerken van de geneigdhelascomponenten van lekenadviseurs.

3) Hiertegen is op te merken, dat de ziektebeleving van lekenadviseurs anders is geopexationaliseerd dan die van de patient, waardoor cen vergelijking moelijk zou gijn. Als de voar de lekenadwiseurs geoperationaliseerde ziektebeleving echter gevoeligex is voox de aurd var de aandoening dan die van de patient, dan zou dit vermoedelijk ook tot uitalrukking komen in verschilien in ziektebeleving van weede lekenadviseurs. Dat is echter niet het geval.

4) 72 = aantal patient-respondenten met minimaal een lekenadviseur.

5) Wily konden hiservoor geen goede verklaxing vinden. Het negatieve verband bleef bestaan, ook als voox die leeftija van de patient of zijn tweede wekenadviseur werd gecontroleerd (Af Kinlay (1973) en salloway (1973)

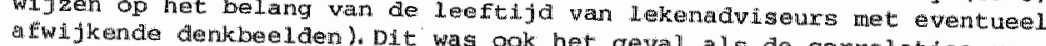
bepalde subgroepen (allen was ook het geval als de correlaties voor ratie, alleen kinderen als tweede, allew pexsonen van dezelfde genewerden berekend. Men kan of weede lekenadviseux geroend) afzonderlijk tingen over zickte on op grond daarvan hooguit aannemen, dat opvattraal. staan in situties, wedische zorg in het algeneen mitet erg cenamdoening niet zo sterk, is thet de betrokkenheid bij "s pationten lekenadwisewrs). Dese zen en ander moet ook worem otatio is evenwel niet erg bevredigend. tussen opvateingen over de medische zor over de contbrekende) samenhang (zile tabel 10.4.)

6) Bijlage 11 bevat enkele details. 
Hoofdstuk 11. Functies van netwerkleden, consumptiegenelgaheld en medische consumptie

11.1. Inleiding

Elk primair sociaal netwerk kent bepaalde eigen reactlepatronen op klachten en ziekten wan een van de netwerkleden. Het ontstaan van deze reactiepatronen in de loop der jaren is een complex proces. Het is vooral afhankelijk van wederzijdse warden, normen en verwachtingen en van de functies, die de leden van het lekennetwerk woor elkaar vervulien. To kan een klacht "ik voel me zilek" binnen het ene netwerk betekenen "laat me met rust" terwijl diezelfae klacht binnen een ander netwerk een roep om hulp impliceert (van Eijk, 1979). In hoofdstuk 2 werd al benadrukt, dat primaire sociale netwerken, waarvan een der leden chronisch ziek is, weer speclfleke reactiepatronen ten aanzien van die aandoening ontwikkeld kunnen hebben (Callahan, 1966, Litman, 1974, Bruhn, 1977).

De functies die leden van het netwerk door dit soort reacties voor elkaar kunnen vervullen met het oog op behoud of herstel van hun gezondheid krijgen in Nederland veel aandacht. Daarbij speelt vooral de gedachte een rol, dat gezondheld en ziekte verschijnselen zijn, die binnen het gezin of huishouden optreden en in deze context hun betekenis krijgen (Heydendael, 1972, Boeckhorst e.a., 1977. Huygen, 1978, Smits, 1978, Kuyvenhoven en Touw-otten, 1978, Wan Eijk, 1979). In het buitenland is nogal wat andacht besteed aan de functies, die verschillende netwerkleden - familieleden in vergelijking met vrienden of buren bijwoorbeeld - vervullen (Salloway en Dillon, 1973. Finlayson, 1976. Froland, 1979).

be gevolgen van de reactiepatronen blnnen het netwerk kunnen voor de leden en vooral voor de patiẻnt verschillend zijn. Boekhorst e.a. (1977) en Van E1Jk (1979) zijn daarop utitgebreid ingegaan. Eenvoudig gesteld - en zonder verder op de achterliggende mechanismen in te gaan - kan men twee extreme gevolgen onderscheiden: of de reacties van netwerkleden geven aanleiding tot bestendiging en versterking van de patiéntenrol ("somatische Eixatie", Boeckhorst $\left.e_{\text {a. }}, 1977\right)$, of zij bewerkstelligen 
het tegenovergesteide. Bij dat latste vervullen de netwerkieden als het ware probleenoplossende functies, die een eventuele behoefte aan ziekte- of patientenrolgedrag doen afnemen (Mechanic, 1968).

Dit hoofdstuk besteedt andacht aan verschillende gedragingen van lekenadviseurs in relatie met de consumptiegeneigdheid en de feltelijke medische consumptie van de patiënt en daarme an de onderzoekshypothesen 3.2. en 4. Deze hypothesen ludiden: (3.2.) lekenadviseurs, die de patient in praktische of emotionele zin helpen, zullen $z i j n$ consumptiegeneigdheid doen afnemen en (4) iemands medsche consumptie neemt toe, naarmate de consumptiegenelgahedd van zijn lekenadviseurs (zoals in hookdstuk 10 is gedefinieerd) toeneemt. Met het voorgande is echter angegeven, dat bij onderzoek naar de functies van netwerkleden en vooral bij de interpretatie daarwan voorzichtigheld geboden is. Een functie, die in de ogen van de onderzoeker "verlichtend" of "probleemoplossend" is, behoeft dat in de ogen van bepalde netwexkleden riet te zijn en omgekeerd. Voorts zullen hulpverlening en emotlonele steun tot op zekere hoogte aansiulten bij bepalde behoeften van de patiërt, zonder dat precies is na te gaan, in welke mate de ziekte daartae "objectef" gezien inderdaad een aanleiding vormt.

De hiernavolgende analyse heeft derhalve een mindex toetsend karakter, dar op het eerste gezicht lijkt. De eventuele relaties tussen onafhankelijke (gedragingen van netwerkleden) en afhankelijke variabelien (consumptiegeneigdheid en feitelijke consumptie) zullen in onderlinge samenhang moeten worden geinterpreteerd, warbij tevens de indicatieve warde van de gedragingen van lekenadviseurs zal worden beoordeeld. Paragraaf 11.2. gaat nader in op de praktische hulp verleend door netwerkleden, paragraat 11.3. Op hun emotionele steun voor de patidnt bij de verwerking van het feit, dat hij chronisch zjek is. Dit onderscheia tussen instrumentele en expressieve functles van netwerkleden baseren wij op de bevindingen van Booth en Babchuk (1979). In paragraaf 11.4. komt tenslotte de invloed van de consurptiegenelgaheid van lekenadwseurs op de medische consumptie van de patient an de orde. Het hoofdstuk besluit met een korte beschouwing ten aanzien van de voornaamste conclu-
sies. 
11.2. Instrumentele functies van netwerkieden: praktische hulp in verband met de andoeming

Als mer een chronische aandoering heeft, is men wel ebus op de hulp van anderen aangewezen. Dat gelat bljvoorbeela voor psorlasis-patienten, die soms grote delen van het licham met zaif moeten behandelen of voor hartinfarctpatienten, dle bepallde huishoudelijke taken niet langer kumen verrichten.

wij hebben - gezien de verscheidenheid van mogelijkheden tot hulpveriening - een globale mat berekend voor de mate warin de lekemadviseurs dit soort instrumentele functies voor de patiënt-respondent vervullen. Deze mat is samengesteld ujt antwoorden op twee vragen aan lekenadviseurs: Een naar een specifleke vorm van hulp ${ }^{1)}$ en een nax overige hulp ${ }^{2)}$. De mate warin hulp wordt verleend is bepald door na te gaan, of beide lekenadviseurs op beide vragen positief reageerden (veel. bulp) dan wej, of zij dat beide niet deden (geen hulp) en met verschillende tussenvormen. Tabel 11.1. lat de verdeling van deze vaxiabele per patiëntencategorie zien. De verschilien tussen de graepen zijn niet significant. ${ }^{3)}$

Tabel 1.1. Mate van hulpwerlening door lekenadviseurs nat patiëntencategorie

\begin{tabular}{lccc} 
& hartinfart & diabeses & psoriasis \\
\cline { 2 - 4 } veel hulp & 6 & 4 & 0 \\
huip & 4 & 4 & 3 \\
geen hulp & 7 & 5 & 4 \\
$\begin{array}{l}\text { geen lexenadviseurs/ } \\
\text { geen informatie }\end{array}$ & 8 & 11 & 18
\end{tabular}

Bestat er een samenhang tussen consurptiegeneigdheld en vexkregen hulp? Tabel 1.2. vergelijkt twee -wat hun hulp betreft - uiterste groepen. Conform onze hypothege verwachten wij. dat de groep die hulp ontvangt minder tot medische consumptie geneigd zal zijn dan de andere groep.

Dit resultat is in tegensprak met onze verwachting. Het is op de meeste punten niet significant max toch vrij dulde- 
Lijk: personen in netwerken, warln veel hulp aar de patiêt wordt vex leend $z i j n$ over het algeneen allen - patient, eerste en tweede lekmadviseur - lets meer tot medische consumptie genelgd dan persomen in netwerken warin dat niet gebeurt. Het wall op, dat de ziektebelewing van de lekenadviseurs zelfs significant slechter is, wanneer $z i j$ de patiênt helpen, dan waneer $z i j$ dat niet doen.

Hoe kan at worden geinterpreteexd? zeer waarschijniju blijkt hieruit een zekere overbezorgakeid, die de adviseurs tot helpen anzet. Hierdoor ontstat de kans, dat zij de paticht in zijn patientenrol stexken in plats van hem te helpen. Er zou, met andere woorden, sprake kunnen zijn van een zekere mate van somatische fixatie (Boeckhorst e.a., 1977) binnen het lekennetwerk. Wij komen daarop nog terug. Eerst vragen wij ons af, of er een relatie bestat tussen hulpverlening en feltelijke medische consumptie van de patiënt.

Wij willen ait niet rechtstreeks nagaan mar proberen, de medische consumptie apart te bezien van categoxieën die - op grond van bepaalde indicatoren - vergelijkbaar zijn in de ernst van hun aandoening (consumptienoodzaak). Het is immers zeer wel mogelijk, dat mensen meer hulp krijgen, omdat zij ernstiger ziek zijn, en dat zij daaxdoor ook meer behoeft hebben aan huisartscontacten. Tabel 11.3. laat zien, dat deze laatste verondersteling echter max tot op zekere hoogte waax is.

De uitkomsten verschillen, afhankelijk van welke indicator voor consumptienoodzaak men kiest. De ziektebeleving van de patient differentieert het meest voor het antal huisartscontacten. Men zou daarom kumen zeggen, dat deze indicator mier in ieder geval op subjectieve, bij de patient gelegen gronden een goede matstaf is voor de ervaren noodzalk woor doktersconsulten. Het blijkt dan ook, dat patidnter met een siechte zlektebeleving - hulp of geen hulp - vaker nar de hulsarts gaan, dan patibnten met een goede beleving. Toch valt op, dat bimnen nar die ziektebeleving onderscheiden categorieen, personem met veel hulp meer huisartscontacten vertonen, dan personen, die geen lekenhulp krijgen.

Kijkt men nax het woorkomen van overige aandoeningen, dan blijken patienten die hulp krijgen en nog overige aandoe- 
Tabel 11.2. Consumptiegeneigdheid naarmate van verkregen hulp (mann-Whitrey-toets, tweezijaig)

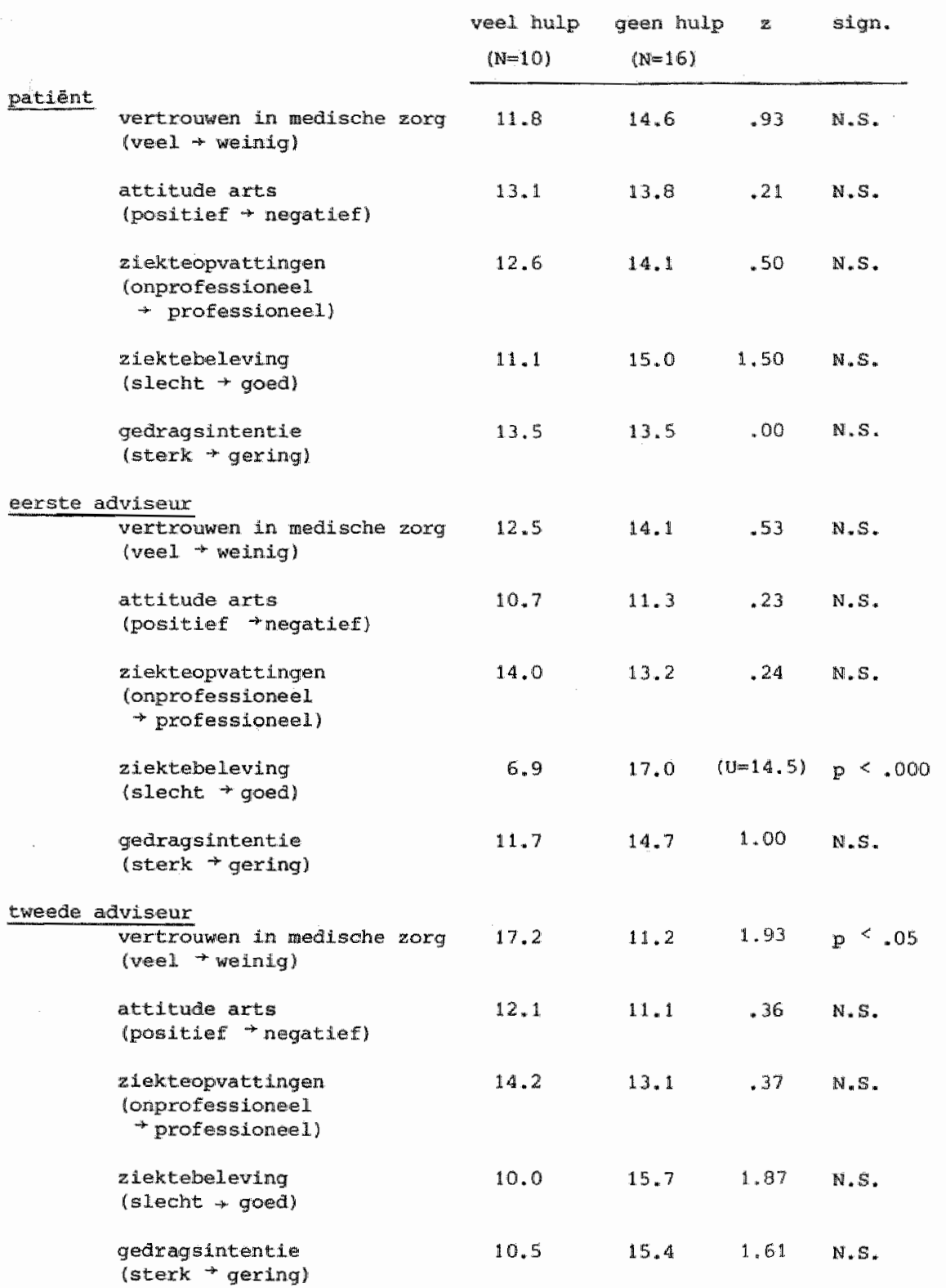


Tabe 11.3. Gendadela dantal husartscontacten naw ernst van de aandoending en howed theid verkxegen hulp 1 )

\begin{tabular}{|c|c|c|c|c|}
\hline & $\begin{array}{l}\text { mel halp } \\
(\mathrm{n}=21)\end{array}$ & $\mathbb{1}$ & $\begin{array}{l}\text { geen huip } \\
(\omega=16)\end{array}$ & $\mathbb{M}$ \\
\hline $\begin{array}{l}\text { ziektebe leving } \\
\text { pathent want }\end{array}$ & 2.2 & 15 & 1.25 & 8 \\
\hline $\begin{array}{l}\text { zidtebeleving } \\
\text { patient goed }\end{array}$ & 1.0 & 6 & 0.75 & 8 \\
\hline overige aandoeningen & 2.2 & 14 & 0.9 & 10 \\
\hline geteb werlge aandoningen & 1.1 & 7 & 1.2 & 6 \\
\hline $\begin{array}{l}\text { veel voorgeschxeven } \\
\text { controles }\end{array}$ & 1.7 & 7 & 0.5 & 6 \\
\hline $\begin{array}{l}\text { weindg yourgeschreven } \\
\text { controdes }\end{array}$ & 1.9 & 14 & 1.3 & 10 \\
\hline
\end{tabular}

1) Wh hebten - gezien de kleine aantalien - de netwerken met veel verleende hulp gevoga bij de netwerken, waarin niet zovel hulp wordt geboden hetgeen de duidelijkheid van de witkonsten t. g.v. de betroubaacheid ervan doet afnemen: in alle gevallen vertonen namelijk de patienten met de messte hulp ook de meeste huisartscontacten.

ningen hebben, het meest nat de dokter te gaan, mér, dan patienten met overige aandoeningen zondex hulp. Het al eerder genoema voorgeschreven aantal controles - van de drie de meest "objectieve" indicator - differentieext minder voor het aantal huisartscontacten dan de mate van verleende hulp: ongeacht dit aantal controles gaan personen die veel hulp ontvangen, vaker naar de huisaxts dan personen, die geen hulp ontvangen.

Alvorens aan deze bevinding - veel hulp gat njet gepara met weinig mar met veel medische consumptie - een nadere beschouwing te wijtem, wlilen wij eerst nog en aridere reactie Van netwerkleden op de andoening in relatie met consumptiegeneigdheid en medische consumptie bestuderen.

\subsection{Expressieve functies van lekenadviseurs: emotionele steun bij de andoentri}

Om te achtexhalen op welke wijze netwerkleden de patient tegemoet treden en hem vermoedelijk al dan niet als patidit 
behandelen, vroegen wij in welke mate de lekenadviseurs de patient-respondent ziek achten. Een positief antwoord op deze vraag - "Ik acht hem/haar met de aandoening gezond" - kan voor de patient echtex verschiliende functies hebben. Iemam, die zichzelf ziek acht, kan zich door zo"n houding van de netwerkleden miskend en geisoleerd vaelen. Aan de andere kant kan Lemand daardoor juist gestimuleerd worden, on de patientenxol op adequate wijze te anvaarden.

Wij achten het eerste in dit geval niet erg warschijnlijk en wel om de volgende reden. In hoofdstuk 10 bleek een relatief grote mate van overeensteming in consumptiegeneigdheid tussen pätiënt en lekenadviseurs te bestaan. Deze overeenstemming geldt het meest de wijze warrop de netwerkleden de chronische aandoening beleven. Bovendien blijken de beoordelingen van de aandoening door de patiênt en door de lekenadviseurs in sterke mate samen te hangen (tabel 11.4.). Discrepantie in denkbeelden is op dit punt dus niet sterk en hoeft zelfs dan nog niet tot isolatie van de patiënt te leiden. Wij zijn daarom van mening, dat de mate warin netwerkleden de patient gezond achten, mede op grond var eerdere bevindingen in dit onderzoek tot de positief-expressieve functies van lekenadviseurs gerekend kan worden.

Wanneer wij nu de relatie tussen ait oordeel en de feltelijke medische consumptie van de patiënt bestuderen, moeten wij erop bedacht zijn, dat dit oordeel tot op zekere hoogte een afspiegeling zal zijn van de feitelijke ernst van de aandoening. Dit eenvoudig, omdat een ernstig zieke patient over het algemeen ook ziek en een minder ernstig zieke relatief gezond geacht zal worden. Een samengaan van een positlef lekenoordeel met weinig consumptie van de patient zegt dan alieen lets over de geringe ermst van de a ardoenfing en niet over de functie, die zo"n oordeel voor de patient in verband wet zijn medische consumpte vervult.

om enig inzicht te krijgen in de mate warin de beoordeling vam de amdoening door de lekenadviseurs overeenkomt met de objectieve ernst ervan, berekenden wij de samenhang (rho) tussen het lekenoordeel en het oordeel van de artis ower de ernst wan de aandoening (tabel 11.4.). 


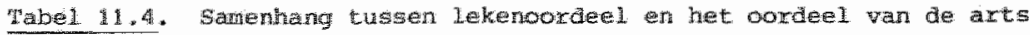
orer de errat van de aradoening

\begin{tabular}{|c|c|c|c|c|}
\hline oordeel van: & $\begin{array}{l}\operatorname{arcts} \\
(1)\end{array}$ & $\begin{array}{l}\text { patiant } \\
\text { (2) }\end{array}$ & $\begin{array}{l}\text { eexste } \\
\text { advinseur } \\
\text { (3) }\end{array}$ & $\begin{array}{l}\text { tweede } \\
\text { adyiseur } \\
\text { (4) }\end{array}$ \\
\hline (2) & .17 & & & \\
\hline (3) & .10 & -377 & & \\
\hline (4) & 56 & .40 & {$[.34$} & \\
\hline
\end{tabular}

Het valt op, dat de overeenkomst in beoordeling van de ernst wan de aandoening tussen arts, patient en eerste adviseur betrekkelijk gering is, en dat darentegen deze overeenkomst tussen arts en twede adviseur nogal sterk is. Hoewel wij nilet verder op de achtergronden hiervan im kunnen gaar, is ait gegeven interessant genoeg om even bij stil te staan.

wij menen, dat het als volgt geinterpreteerd kan worden. De geringe overeenkomst tussen arts, patiënt en eerste lekenadviseur is vermoedelijk uitdrukking van een discrepantie, die inherent is aan de arts - patient - relatie (Persoon, 1975. p. 7, Freldson, 1975, hoofdstuk 14). De patiënt beoordeelt zjjn aandoening met eigen matstaven, die - zoals hier blijkt - niet atijd overeenkomen met medisch-professionele matstaven. Dit geldt ook voor de meest-betrokken lekenadviseur. De vraag is dan, warom de tweede adviseur het op dit punt wel met de arts eens is. Wij menen, dat een tweede adviseur de chronische andoening var de patiënt wellicht afstandelijker beoordeelt en daarbij minder emotioneel betrokken is, dan de patiënt zelf en dan de meest-betrokkene.

Al met al zegt het oordeel van tenuinste de eerste lekenadviseur met over zijn eigen instelling ten anzien van de andoening, dan over de medische betekenis en darmee ovex de "objectieve" consumptienoadzaak ervan.

wij stellen nu de wraag, of en op welke wijze de beoordeling van wlekte door de eerste lekenadviseur samenhangt met (1) de consumptiegeneigdheid en met (2) de feitelijke medische consumptie van de patiënt. Wij verwachten, dat een positief oordeel over de aandoening met geringe genelgdheld tot consump- 
tie zal samenhangen; en voorts, dat patiënten, die door hun adviseur gezond geacht worden, minder naar de dokter gaan, dan anderen. Dit latste moet zoveel mogelijk onarhankelijk wan de ernst van de aandoening worden bepald.

over het eerste deel van de vraag kunnen wij kort zijn. Vijftien Mann-Whitney-u toetsen - op verschilien in vijf geneigdheldscomponenten van drie personen - tonen slechts cen erikele significante uitkomst: de ziektebeleving van de exste lekenadviseur is duidelijk $(\mathrm{p}<.005)$ slechter, als deze de patiënt ziek acht, dan manmeer hij hem gezond acht. Dat is wellicht vanzelfsprekend. Daarnaast valt echter op, dat de ziektebeleving van de patiënt zelf noch die van zijn tweede adviseux op dit punt significant verschillen. Wij moeten hiermee nu ook onze hypothese ten aanzien van de emotionele steun verwerpen. Emotionele steun van de meest-betrokkene, die tot uitarukking komt in zijn benadering van de patient als rede$11 j k$ gezond persoon ook al heeft deze een chronische zlekte, doet de consumptiegeneigdheid van de patient niet afmemen. Tabel 11.5. gaat op het tweede deel van de vraag in: de samenhang met de feltelijke medische consumptie van de patiënt.

Tabel 11.5. Gemiddela aantal huisartscontacten van de patient narar het oordeel van de eerste lekenadviseur over" de andoening eerste lekenadviseur acht patient:

\begin{tabular}{|c|c|c|c|c|}
\hline & gezond & $\mathbb{N}$ & ziek & $\mathrm{N}$ \\
\hline $\begin{array}{l}\text { slechte ziektebeleving } \\
\text { van patiënt }\end{array}$ & 0.87 & 23 & 2.08 & 13 \\
\hline $\begin{array}{l}\text { goede ziektebeleving } \\
\text { van patidnt }\end{array}$ & 0.34 & 29 & 1.29 & 7 \\
\hline ziek wollgens arts & 1.10 & 10 & 0.35 & 4 \\
\hline miet $z o \mathrm{z}$ ek volgens arts & 0.59 & 27 & 1.56 & 9 \\
\hline overige aandoeningen & 0.66 & 29 & 1.75 & 16 \\
\hline geren overige aandoeningen & 0.48 & 23 & 2.00 & 4 \\
\hline veel woorgeschreven controles & 0.74 & 29 & 1.93 & 5 \\
\hline $\begin{array}{l}\text { weinig voorgeschreven } \\
\text { controles }\end{array}$ & 0.4 .5 & 23 & 1.40 & 15 \\
\hline
\end{tabular}


Dit resultat is echtex duldelijker in overeensteming met onze hypothese, dan wij konden verwachten. Het blijkt nl. "dat patienten die door hun lekenadviseux ziek worden geacht - ongeacht hun eigen zlektebeleving, ongeacht het aantal woorgeschrever controles en ongeacht andexe aandoeningen, dat wil zeggen ongeacht een duidelijke mate van consumptienoodzaak - hun huisarte vaker radplegen, dan patienten die door hun adviseurs gezond worden geacht. De rechterkolom ran de tabel telt - op een ultzondexing na - voor alle categorleën meer huisartscontacten dan de linker. De uitzondexing wijsterop, dat slechts Een persoon de invloed van het lekenadviseur-oordeel op de consumptie van de patient kan "overstermen". Dat is het oordeel van de arts. Als hij zegt "u bent ziek", dan brengt dat meer huisartscontacten met zich mee, dan wanneer de meest-betrokken lekenadviseur dat tot uitdrukking brengt. In alle andere gevallen mandfesteert zich echter heel duidelijk de invloed van het lekenoordeel over de ernst wan de aradoening op het aantal huisartscontacten varn de patiënt.

11.4. Consumptiegeneigdhejd van lekenadviseurs en medische consumptie van patiënt-respondenten

In deze paragraaf gaan wij na in welke mate lekenadviseurs - wellicht zonder dat zij dit zelf beseffen - de patientrespondent doox hum eigen consumptiegeneigaheid bij de medische consumptie beinvloeden. Wij verwachten dat patienten vaker nar de hulsarts zullen gaan, narmate hun lekenadviseurs meer tot medische consumptie geneigd zijn. Wij zulien dit op twee manieren nagaan.

In de eerste platas werd eer stapsgewije regressieanalyse uitgevoerd met als afhankelijke variabele het antal huisartscontacten van de patiënt. Als eerste stap werd de controleroodzak an als tweede de consumptiegenelgaheid van de patient in de analyse betrokken. rot zover kont deze werkwijze overeen met die, welke wij in hoofdstuk 7 , paragraaf 7.3 beschreven. Daar bleek, dat - na constant-houding van de contralenoodzak - 20,8 van de variantie in huisartsconsulten door de consumptiegeneigdheid van de patiënt wordt verklaard. Nu is 
tie vraag aan de orde, of de vijf geneigdheldscomponenten van lekenadviseurs dit percentage significant kunnen doer toenemen.

Wij zijn dit alleen voor de eerste lekenadviseur nagegaan $(N=$ max.72). Voor de tweede adviseur beschikken wij immers slechts over maximal 39 warnemingen, ons inziens een te gering aantal om met elf onafhankelijke variabelen in een regressieanalyse te bezien. De resultaten zijn te vinden in tabel 11.6...

De uitkomst komt goed overeen met onze verwachting dienaangande. Het blijkt, dat de consumptiegreneigdheld wan de eerste adviseur nog eens 13,5 toevoegt aan de variantieverklaring van het aantal huisartsconsulten. Dit is woor het overgrote deel te wijten aan de wijze warop deze lekenadviseur de aandoening van de patiënt beleeft. Deze verkalart bijna 13 variantie, metr dan de ziektebeleving van de patjent zelf daartoe bijaraagt. De invloed wan de overige variabelen is gering en niet significant.

De hier gevolgde werkwijze, om inzicht te krijgen in de invloed van de consumptiegeneigdheid van de meest-betroklitene op het aantal mallen waamee de patient zijn huisarts raadpleegt, laat eventuele discrepanties in attituden en opvatingen tussen lekenadviseur en patient buiten beschouwing. Het is echter zeer wel denkbaar, dat meningsverschillen binnen het netwerk van invloed zijn op de medische consumptie van de patient.

De tweede manier om het aan de orde gestelde vraagstuk te benaderen, besteedt expliciet aandacht aan eventuele meningsverschillen tussen netwerkleden. Hij bledt bovendien de mogelijkheid om de inwloed van alie (dxie de) leden op de medische consumptie vam de patiënt te bestuderen. Daarvoor wordt het gemiddeld aantal huisartsconsulten berekend var patinten, die deel uitmaken van - wat de consumptiegeneigdheid betweft homogene en heterogene netwerken. Deze kwamen in hoofdstuk 10 al ter sprake. Tabel 11.7. laat de resultaten zien.

De gegevens tonen de invloed van de consumptiegeneigdhela binnen lekenmetwerken duidelijk aan. Het feit dat dit gegeven voor alle drie de lekenadviseurs niet signiticant is, doet daran weinig af. Naarmate de consumptiegenefgdheld hoger is 
Tabe1 11.6. Mate wariri de wijf genelgdheidecomponenten van de eerste lekenadwiseur het antal huisartsconsulten van de patient bernvlontt istapsgewijze regressie-analyse, gezuiverd voor controlenoodiak en consumptlegenelgaheid var de patient, a $=72$ ) 1)

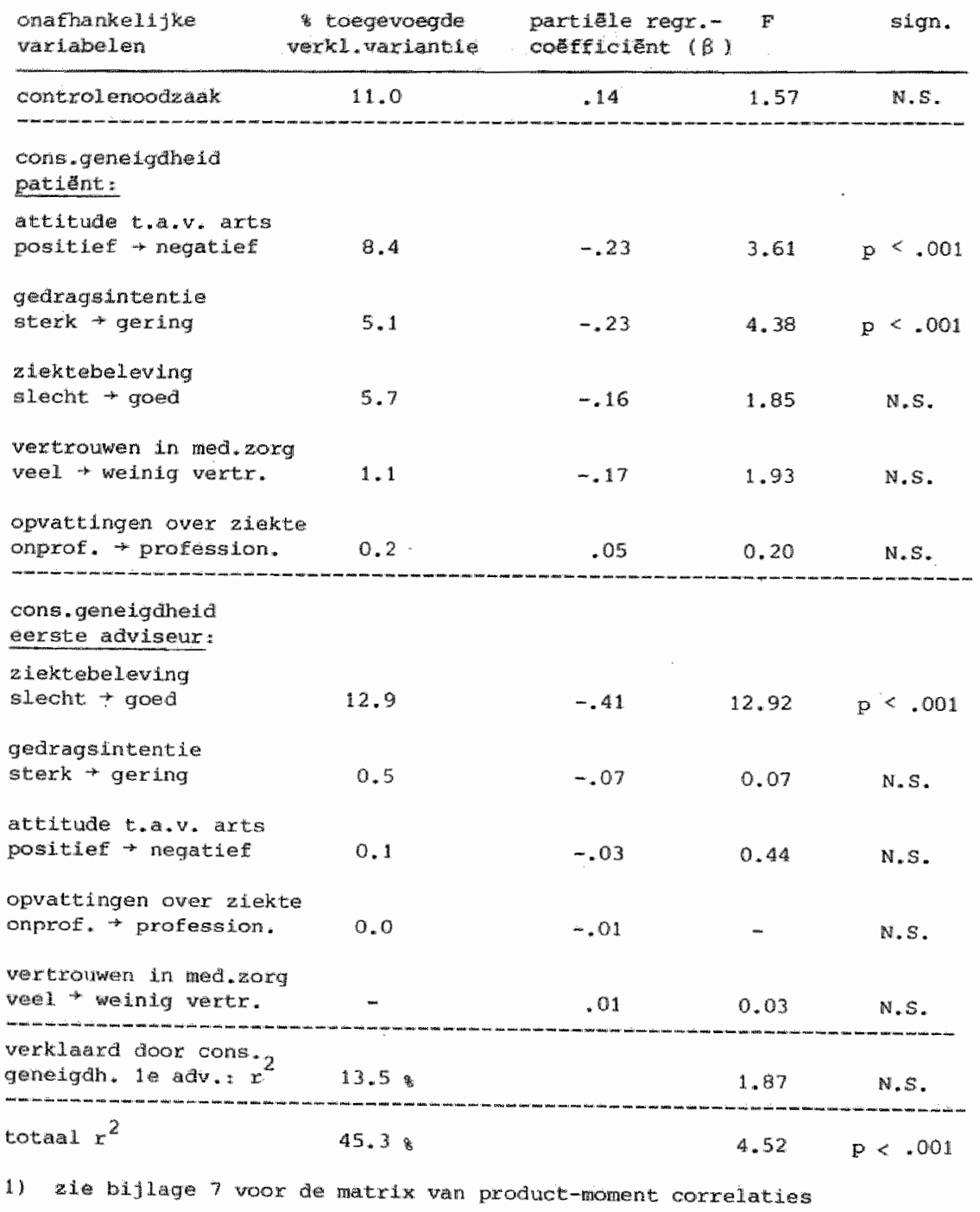


Tabel. 11.7. Gemidald aantal hui . cartscontacten van patienter in honogene en in heterogene netwexken (m.b.t. geneigoheid; eerwegvaxiantie-analyse) homogeen sterk 1.6

heterogeen

0.8

homogeen gering

0.2

$$
F=3.57 \quad F<.03
$$

(21) homogeniteit bij patisnt en beide lekenadviseurs homogeen sterk

1.75

논

heterogeen

1.43

homogeen gering

0.50

$$
E=1.1 \quad \text { N.S. }
$$

en de leden het daarover in grate lijnen eens zijm, gaat de patiënt vaker naar de dokter dan wanneer deze lager is en darmover ook een redelijke overeensteming binnen het netwerk bestaat. Heterogene netwerken nemen wat dit betreft een tussenpositie in.

Dat latste ligt overigens niet zonder meex voor de hand. Heterogeniteit zou immers op spanningen binnen het netwexk kunnen wijzen of ook op onverschilligheid ten aanzien van attituden over ziekte en zorg van bepalide leden. Deze zaken zouden juist bij kunnen dragen tot een verhoogde medische consumptle van de patiënt, bijwoorbeeld ten gevolge van stress. (Mechanic, 1968, Shuval, 1972.). Onze gegevens wijzen daar echter niet op. Zij geven veeleer anleiding tot de conclusie, dat weinig overeensteming binnen het netwerk noch tot veel noch tot weinig consumptie leidt. Men kan de heterogenitelt van denkbeelden tot op zekere hoogte opvatten als een ultdukking van een relathef geringe hechtheid van het netwerk. Relatief, omdat de door ons bestudeerde leden van primaire soclale netwerken pex definitie hechte bander hebben. Zo bezien komen onze resultaten overeen met de veronderstellingen van Freidson (1975): minder hechte netwerken vertonen en middelmatige medische consumptie. 


\subsection{Tot bes lut}

De bevinanger uit de vorige paragrafen geven aanleiding tot de volgende conclusie. Lekenadvigeurs wan chronjsche patienter oefenen een belangrijke invioed uit op de medische consumptie van die patienten en wel op verschillende manieren.

In de eerste plates - zo vonden wij - gat allerlel hulpverlening in verband met de aandoening tot op zekere hoogte gepara met en sterke consumptiegenelgdheid van de retwerkleden. Deze vindt zijn uitarukking in reiatief veel medische consumptie - in ternen van huisartscontacten - van de patient, ten dele zelfs ongeacht de exnst van zijn aandoening.

In de tweede plats werd een sameniang geconstateerd tussen de mate warin de meest betrokken lekenadviseur de patient -respondent zlek acht en zijn hoeveelheda medische consumptie. Daarbij bleek dit lekenoordeel niet significant samen te hangen met het oordeel van de arts over de ernst var de aandoening van de patiënt, evanmin trouwens als het oordeel van de patient zelf darover. In op Een na alle gevalien, warin de meest betrokkene de patiënt ziek acht, gaat deze vaker naar de huisarts dan wanneer hij gezond wordt genoema. Dit ongeacht de - op verschillende manieren achterhalae - mate van consumptwienoodzaak.

In de derde plaats bieek de consumptiegeneigdheid van (een van de twee) wekenadviseurs een duidelijk extra bijdrage aan de verklaring van het aantal huisartscontacten van de patient te leveren, boven die van de patient zelf.

Tenslotte werd aangetoond, dat cok de consumptiegeneigdheid van alle drie netwerkleden tezamen zijn weerslag vindt in de medische consumptie van de patiënt.

Hoe kunnen deze bevindingen tegen het licht wan onze onderzokshypothesen worden geinterpreteerd? Deze moesten immers gedeeltelijk worden verworpen: praktiche hulp ging niet gepard met weinig mar juist met veel huisartscontacten, emotiorele steun hing niet duidelijk met de consumptiegeneigaheid van de patient mar wel met zijn medische consumptie samen. Alleen hypothese 4 ten aanzien van de invloea van consumptiegeneigdheld wan lekenadviseurs kan worden gehandhafa.

Het vorgande makt duidelijk, dat de hypothese aangan- 
de praktische en emotionele steun te ongenuanceerd gesteld is. 21 I houdt onvoldoende rekening met het felt, dat een bepalde mate van hulp en steun geen verlichting biedt voor de patient. maar deze juist in zijn patientenrol kan bevestigen. Deze kont zeer warschijnlijk voort ult een zekere mate van overbezorgdheid van netwerkleden van chronisch zieken. Deze overbezorgaheld komt niet alleen tot uitarukking in (te) veel hulp en steun maax tot op zekere hoogte ook in een verhoogde mate van consumptiegeneigdheid van lekenadviseurs. Wij herinneren hiervoor aan het steeds opnleuw gebleken belang van de zilektebeleving van ten minste de meest-betrokkene. Dit kan van betekenis zijn omdat onderinge bernvloeding van netwerkleden op het punt van consumptiegenelgdheid - anders dan op het punt van praktische hulpverlening - vermoedelijk nogal impliciet en door de leden onbewust plaats vindt.

Deze interpretatie wordt gesteund door bevindingen van Boeckhorst e.a. (1977), Kuyvenhover en Touw-otten (1978) en Smits (1978) voarzover deze betrekking hebben op overeenkomsten in ziektegedrag tussen gezinsleden. Voorts geven zij steun aan de veronderstellingen van Freidson (1975), die betrekking hebben op de medische consumptie van hechte, nl. primaire soclale netwerken en aan de theorie van sociale netwerken in het algemeen (Bott, 1957, Mitche11, 1969). Naarmate deze netwerken er attituden en opvatingen op nahouden, ale net professionele denkbeelden overeenstemmen, neemt hun medische consumptie toe.

Men kan tweeërlei opmerkingen blj het voorgaande plaatsen. Ten eerste hebben wij met onze operationaliseringen wan functies van netwerkleden en met onze analyse van samenhangen tussen die functies en consumptie(genelgdheld) wel gepoogd, om an de in de inlelaling genoemde theoretische en methodische bezwaren tegemoet te komen. Dat neemt niet weg, dat dit soort bezwaren noojt geheel kunnen worden geëlimineerd. zo kan men onze indicatoren woor consumptienoodzaak onvoldoende gelaig achter $^{5}$ of onze operationaliserting van een positief-expressieve functie van netwerkleden tautologisch. Wij menen evenwel, onze conclusies te mogen trekken, onat wj deze baseren op een zekere hoeveelheid van verschillende informatle, verkmegen door verschillende, af zonderlijk ondervraagde personen. 
In de tweede plates kan men zlch atvragen in welke mate deze conclusie ook betrekking heeft op netwexken zonder chronich zleke leden. Kan men op grond ervan ook beweren, dat netwerkleden vergelijkbare invloed op elkaars consumptie (genelgdheid) uitoefenen, ook als niemand van hen chronisch patient is? wij kunnen hierop met ons material ulteraard geen antwoord geven. In hoofdstuk 3 hebben wij dit punt al ter sprake gebracht er daar de mogelijkheid beschreven, dat verschillen tussen netwerken met en zonder chronische patiënten eerdex gradueel dan wezenlijk zullen zijn. Toekomstig onderzoek zal moeten uitwijen, of dat snderdaad het geval is.

\section{NOTEN BIJ HOOFDSTUK 11}

1) Namelijk bij huishoudelijke karweitjes (H), aanpassing van eigen eetgewoonten aan die van de patiënt (S) en hulp bij het zalven (P).

2) Dichotoon gecodeera: wel - niet verleend, hierbij wera bijvoorbeeld genoemd "met de auto wegbrengen", "boodschappen voor hem/haar doen" (H), "s nachts brood klaamaken als dat nodig i.s" "huishoudelijk werk" (S), "de was doen", "ramen zemen" (i.v.m. hinder t.g.v. watercontact) (P).

3) Zle ook biliage 11 woor enkele achtergroncen.

4) voox onze overwegingen, om deze parametrische techniek toe te passen, ook al voldoen onze gegevens niet aan de eisen die zij stelt, zlj verwezen nat hoofdstuk 7 .

5) verhadk (1981) toonde bljw, aan, dat het oordeel van werschillende artsen ovar de mate warin klachten van hun patienten psychisch van atra wren, meer zegt over de arts die het cordeel uitspreekt, dan over de mate whin de klacht inderdaad psychische achtergronden had. Het oordeel, clat wij an de arts vroegen, haa echter betrekking op betrekkelijk objectief vastgestelde kermerken van het hartinfarct, de diabetes en de psoriasis. 
Eoofdstuk 12. Samenvatting en discussie

In deel III van deze studie stond het lekennetwerk centraal. In hoofdstuk 9 werden vooral $\mathrm{zijn}$ structurele kenmerken beschreven, in hoofastuk $10 \mathrm{kwamen}$ de opvattingen en attituden ten anzien van ziekte en zorg van de netwerkleden aan de orde. Hoofdstuk 11 besteedde tenslotte aandacht aan verschillende functies, die lekenadviseurs voor een chronisch ziek netwerklid kunnen vervulien.

Wij willen de lezer van dit hoofdstuk niet vermoeien met een opsoming van alle bevindingen uit deze hoofdstukken. Daarvoor zij hij verwezen nar het slot van paragraaf 9.4. en naar paragraaf 11.5. Volledigheidshalve zullen wij wel de resultaten met betrekking tot de onderzoekshypothesen herhalen. Zie hoofdstuk 3. par. 3.3.). Fypothese

3.1. met betrekking tat verschillen in consumptiegeneigdheid tussen lekenadviseurs van de arie patiëntengroepen moest worden verworpen; wij vonden slechts sen verschil (van de tien mogelijke), $n$ l. dat meestbetrokken lekenadviseurs van hartinfarctpatiënten de aandoening van de patiënt slechter beleven dan adviseurs van diabetici en deze weer slechter dan de netwerkleden van psorlasispatiënten;

3.2. met betrekking tot een veronderstelde geringe consumptiegenelgheid bij (in feite ten gevolge van) hulp en steun, werleend door netwerkleden moest eveneens worden verworpen; wij vonden ten aanzien van de hulp eerder het tegenovergestelde, nl. dat veel verleende hulp in zwakke mate met veel consumptiegeneigdheid gepaard gaat. Wel bleek steun in termen van een benadering van de chronisch-patient als relatief gezond persoon met weinig feitelijke medische consumptie samen te hangen. Veel hulp tenslotte, ging darentegen gepara met veel medische consumptie.

4. met betrekking tot de unvloed van de consumptiegeneigdheid van lekenadviseurs op de feitelijke riedische consumptie van de patient werd in meer dan Eén apzicht bevestigd. 
Alvorenz op de bevindingen uit dit deel nader in te gaan, wilen wij deze op overzichtelijke wijze samenvaten. Daarvoor betrekken wij de belangrijke kenmerken van het netwerk, die dit deel dan het licht bracht, tezamen in een regressie-analyse. waarbij wij het aantal huisartscontacten van de patiënt als afhankelifke variabelle beschouwen. Voorts controleren wij voor het antal voorgeschreven controle-consulten en voor lae belangrifkste componenten van) de consumptiegenelgaheid van de patient door deze als eerste stappen in de analyse op te nomen. Whj kozen de volgende netwerkkenmerken als onafhankelijke variabelen:

- onvang van het partiële netwerk (zie hoofdstuk 9. paragrafen 9.2 en 9.4 .1

- de ziektebeleving van de meest-betrokken lekenadviseur (zie hoofdstuk 10, paragraaf 10.2. en hoofdstuk 11 , paragraaf 11.4. )

- het oordeel wan de meest-betrokken lekenadviseur over de andoening van de patiënt als (bijnal gezond of als (ernstig) ziek (zie hoofdstuk 11 , paragraaf 11.3.)

- de mate van consumptiegeneigdheid tussen patiërt en zijn eerste lekenadviseur (zie hoofdstuk 10, paragraaf 10.4, en hoofdstuk 11 , paragraaf 11.4.$)$.

Tabel 12.1. laat de resultaten zien.

Uit de gegevens blijkt heel duidelijk de adaitionele bijdrage, die verschillende netwerkkenmerken aan de verklaring van medische consumptie toevoegen. Daarbij is de invloed van de omvang var het hele netwerk alsmede die van de emotionele steun onbeduidend, de overige kenmerken dadrentegen hebben een zelfstandige en sterke invloed. Tezamen verklaren de netwerkkenmerken 13.9 variantie, nadat de controlenoodzaak en de consumptiegenelgdheld van de patient (zijn ziektebeleving en zijn attitude ten aanzien var de elgen arts) zijn ingevoerd. Dit resultat is signiflcant.

Welke betekenis kan men aan deze resultaten toekennen? Wij hebben daarover in het voorgande al het een er andex gezegd lin hoofastuk 9 paragraaf 9.4 . en in hoofdstuk 11 paragraaf 11.5.). De belangrijkste conclusle is ons inziens, dat personen in de nabijheid van eem (chronische) patient deze 
Tabel 12.1. Mate waarin enkele netwerken het aantal hwisartsconsulten verklaren (stapsgewijze regressie-analyse, gezulvexd voor controlenoodzaak en enkefe geneigdheidscomponenten van de patient, $N=\max .74$ )

\begin{tabular}{|c|c|c|c|c|}
\hline $\begin{array}{l}\text { onathankelsjke } \\
\text { wariabelen. }\end{array}$ & $\begin{array}{c}\text { percentage toiege- } \\
\text { voegde verkiarirde } \\
\text { variantile }\end{array}$ & $\begin{array}{l}\text { maltiple } \\
\text { regre } \\
\text { coeffi- } \\
\text { cient }(\beta)\end{array}$ & $F$ & sign. \\
\hline $\begin{array}{l}\text { controlienoodzaak } \\
\text { weinig - peel }\end{array}$ & 11.0 & .12 & 1.07 & $M_{S} S$ \\
\hline $\begin{array}{l}\text { attitude pationt t.a.v. arts } \\
\text { positief }+ \text { negatief }\end{array}$ & 8.4 & -.23 & 4.47 & $p<.001$ \\
\hline $\begin{array}{l}\text { ziektebeleving patient } \\
\text { slecht } \rightarrow \text { goed }\end{array}$ & 4.9 & -.09 & .56 & $N_{\ldots} \mathrm{S}$ \\
\hline $\begin{array}{l}\text { ziektebeleving eerste adviseur } \\
\text { slecht } \rightarrow \text { goed }\end{array}$ & 10.5 & -.34 & 8.67 & $p<.001$ \\
\hline $\begin{array}{l}\text { mate wan geneigdheld } \\
\text { veel } \rightarrow \text { weinifg }\end{array}$ & 2.3 & -.19 & 2.85 & $p<.01$ \\
\hline $\begin{array}{l}\text { oordeel eersto adviseur } \\
\text { over ziekte } \\
\text { gezond } \rightarrow \text { ziek }\end{array}$ & 1.1 & .12 & 1.13 & N.S. \\
\hline $\begin{array}{l}\text { onvang netwerk } \\
\text { klein + groot }\end{array}$ & * & .00 & - & W.S. \\
\hline $\begin{array}{l}\text { totalal } r^{2} \text { door netwerk- } \\
\text { kenmerken. }\end{array}$ & 13.9 & & 2.67 & $p<.05$ \\
\hline totaal $r^{2}$ & 38.3 & & 5.85 & $p<.001$ \\
\hline
\end{tabular}

1) bijlage 7 bevat de matrix van product-moment correlaties

blijkbaar op verschillende manieren en nogal sterk in zijn consumptie (geneigdheid) beinvloeden. Dit geldt sterker nax mate de aandoening exnstigex is. Dan namelijk worden er meer mensen bij het doen en laten van de patiënt betrokken (hoofdstuk 9, paragraaf 9.2. en paragrat 9.4.), die allen hun inwloed zullen doen gelden.

Men kan deze algemene bevinding op grond van onze gegevens nog iets nuanceren. Het bleek dat voorald de meestbetrokken lekenadviseur zijn of haar invloed doet gelden. 
Deze beleeft de aandoening in kwestie slechter, naamate deze ernstiger is, niet - of althans in veel mindere en niet significante nate - de patient zelf en niet zijn tweede lekenadwiseur. Wij veronderstelden, dat deze tweede lekenadviseur over het algemeen iets afstandelijker tegenover de aandoening staat (hoofdstuk 10, paragraaf 10.3 . en hoofdstuk 11, paragraaf 11.3.)

Wij hebben voorts gezien, dat patienten in homogene netwerken, warin ten aanien van een sterke consumptiegeneigdheid overeensteming bestaat, ook inderdaad veel medische consumptie vertonem. In tabel 12.1. verklaaxt deze mate van consumptiegenelghheld alleer 2,3 variantle nadat een belangrijk deel van de consumptiegeneigaheid van patiënt en eerste lekenadviseur in de analyse zijn ingevoerd.

Al met al zal de invloed van netwerkleden op den duur bepalend zijn voor de verwachtingen, die lekenadviseurs hebben ten aanzien van het gedrag van de patient en voor de normen, watadn de netwerkleden in verband met de aandoening moeten woldoen. zij zullen elkar op de naleving ervan controleren. Marmate de overeensteming ten anzien van die normen en verwachtingen binnen het netwerk toeneemt, neemt het aantal gearagsalternatieven - waronder het wel of niet raadplegen van de arts - voor de netwerkleden vermoedelijk af.

De resultaten van dit deel komen - zoals reeds opgemerkt met veronderstellingen en bevindingen wit de theorle van sociale netwerken overeen. voorts tonen zij aan, dat de mate warin functies van netwerkleden in verband met (chronische) ziekte probleemoplossend kunnen zijn - in die zin, dat zij de (geneigdheid tot) medische consumptie doen afnemen - moeilijk te bepalen is. De kans is groot, dat goedbedoelde vormen van "problemoplossing" juist het tegenovergestelde bewerkstelligen. Somatische fixatie en bestendiging van de patientenrol (in de engexe betekenis, zie hoofdstuk 3) zijn dan het gevolg. 
DE E I I I V

H E T P R O F E S S I O N E L E S S 
Hoofdstuk 13. Verschillen tussen hulsarts-en specialistpatiënter

\subsection{Inleiding}

In hoofdstuk 4 en ook in hoofdstuk 7 kwam al ter sprake, dat 4 van onze respondenten opgaven, hun specialist te zullen raadplegen, als $z i j$ voor het hartinfarct, aiabetes of psoriasis behandeld willen worden. Dertig respondenten noemden in ait verband de huisarts. De aard van de aandoening was daarbij niet van belang: het aantal huisarts-en speclalistpatienten is in de drile patiëntencategorieën ongeveer even groot laie tabel. 4.6.). In dit hoofdstuk willen wij nagaan, in elke mate de twee groepen op andere punten verschillen: zijn specialistpatiënten "zieker" dan huisartspatiënten, verschillen zij in bepaalae persoonskenmerken van elkaar? En natuurlijk stellen wij de vragg: onderscheiden de twee groepen zich naar hun consumptiegeneigdheid? Bij de beantwoording ervan zullen wij bijzondere aandacht besteden an de attituden ten aanzien van de eigen arts.

\subsection{Kenmerken van de aandoeningen}

Men kan veronderstellen, dat controle of behandeling door specialisten eerder voorkomt bij patienten die on bepaalde redenen ernstíger ziek zijn, dan bij minder ernstig zieke patiënten. Nu is het niet mogelijk, om met behulp van enquetegegevens aam te geven in welke mate specialistenbehandeling noodzakelijk is. Ons materiaal bevat echter verschillende indicaties voor de "ernst" van de aandoening, die allen tezamen hierin, zjj het een globaal maar toch een redelijk 1 nzicht kunnen geven.

Wij Introduceren hiervoor de volgende varlabelen.

1. Heeft de patiënt behalve de andoening ln kwestle nog andere aandoeningen of ziekten (volgens opgave patiënt).

2 . De ernst van de aardoening volgens opgave van de arts; het nadeel van deze variabele is de onvolledige informatie: van 21 respondenten is dit gegeven niet beschikbaar (zie bijlage 16). 
3. De Exequentie warmee men hinder wan bepaalde ziektesymptomen ondexvindt (zie bijlage 4 ).

4. Het aantal gedragsadviezen, dat men var de dokter gekregen heeft (zie bijlage 4 ).

In tabel 13.1. zijn deze gegevens voor huisarts- en specialistpatienten afzonderlijk weergegeven.

Tabel 13.1. Enkele fndicaties voor de ernst van de aandoening naax behandelend artes (absolute dartallen resp. ranggemiddelden)

$\begin{array}{cc}\text { huisarts- } & \text { specialist- significantie } \\ \text { pationten } & \text { patienten } \\ (N=30) & (N=44)\end{array}$

1. Overige aandoeningen

$\begin{array}{lllc}\text { ja } & 18 & 29 & x^{2}=0.27 \\ \text { neen } & 12 & 15 & \text { N.S. }\end{array}$

2. Ernst van de adadoening:

volgens axts

$$
1 \text { icht }
$$

licht noch exnstig

exnstig

3. Frequentie optreder:

z1ek tesymptomen

ranggemiddelden

o.g.v. Mann-

Whitney-toets

3.1. hartunfartpatienten

1. 1.0

14.33

(eenzijadig)

3.2. diabetici

16.09

10.57

3. 3. psoriasispatiênten

10.39

13.77

$z=1.11$

N.S.

4. Aantal gedragsackilezen

(als bij 3)

4. 1. Martinfaxctpatienten

4.2. Alabetici

12.4

13.4

10.27

15.14
10.83

$$
\begin{gathered}
x^{2}=4.55 \\
\text { N.S. }
\end{gathered}
$$

4. 3. psoriasigpatiantem

13.5 $z=0.34$

N.S.

$z=1.88$

$\mathrm{p}<.03$

$z=1.15$

N.S.

De afzonderlijke uitkomsten wijzen er niet op, dat specialistpatienten ernstiger ziek zijn, dan huisartspatiënten. slechts in een geval is de uitkomst slgmiflcant in de veronderstelde richting: diabetici, die onder behandeling van de 
specialist zijn, hebben gemiddeld meer gedragsxegels, dan diabetiei onder huisartsbehandeling. Daarbij is de warde van deze indicator (aantal gedragsregels) voor het te indiceren verschijnsel (ernst van de aandoening) overigens vergeleken met de overige indicaties het meest voor discussic vatbaar.

op Een ultkonst na (frequentie warmee zlektesymptomen bij diabetici optreden) wijzen echter alle resultaten in de veronderstelde richting. Wij concluderen darom, dat specialistpatiënten wel wat "ernstiger ziek" zijn dan huisartspatienten, maar dat de verschilien in deze tegen de verwachting in erg gering zijn.

of een patiënt zich voor behandeling tot een specialist dan wel tot de huisarts zou richten, hangt veelal van de duur van de aandoening af. De specialist treedt meestal in de beginperiode op. Hij stelt of bevestigt de diagnose en schrijft een bepalde behandeling voor. Als er verder geen complicaties optreden, kan de hulsarts in veel gevallen de begeleiding van de patiënt overnemen.

zijn de door ons ondervraagde huisartspatiënten langer ziek dan de specialistpatiënten? Tabel 13.2. lat zien, dat dat niet het geval is.

Tabel 13.2. Duur van de aandoening naar behandelend arts

\begin{tabular}{|c|c|c|}
\hline & $\begin{array}{l}\text { huisartspatienten } \\
\qquad(\mathrm{N}=30)\end{array}$ & $\begin{array}{c}\text { speciall istpatisnten } \\
(N=44)\end{array}$ \\
\hline$<5$ jaar & 19 & 27 \\
\hline$>5$ jaar & 10 & 15 \\
\hline onbekend & $\mathbb{1}$ & 2 \\
\hline
\end{tabular}

De Melker heeft erop gewezen, dat het yoor hulsartsen in vele gevallen moeilijk is om te beslissen, of een pateint wel. of niet naar de specialist moet worden verwezen. De criteria zijn hiervoor vaak niet hard of spreken elkaar tegen. (De Melker, 1979, P. 83.) onze resultaten sluiten hierbij aan. De vraag, of een chronische patiënt door de huisarts dan wel door de specialist behandeld moet worden is - gezien deze bevindingen en daardoor uiteraard met enig voorbehoud - blifkbaar ook niet altija gemakkelijk te beantwoorden. 
13.3. Kenmerken van de patiert

Wat kan men veronderstellen over aie samenhang van persoonskenmerken en de vraag of zij huisarts- of specialistpatient zijn? Men kan hierover slechts veronderstellingen formuleren op grond wan gegevens over antallen verwjjingen nar en contacen met speclallsten. Het antal contacten de medische consumptie van huisarts- en specialistpatienten komt in paragraf 5.3. van dit hoofdstuk aan de orde. Uit de 1 iteratuur is bekend, dat huisartsen in gebieden, die door een hoge urbanlsatiegraad gekenmerkt worden, meer naar specia11 ben verwijen, dan huisartsen in minder geurbaniseerde gebieden (Hoeksma, 1979). Voorts $21 j n$ er aanwijzingen, dat ziekenfondspatienten vaker nax de specialist worden verwezen, dan particulier-verzekerden (Van de Ven e.a." 1981). Op grond daarvan zou men van specialistpatiënten kunnen verwachten, dat zij een relatief laag opleidingsniveau hebben bereikt. Voor de persoonskenmerken leeftijd en geslacht verwachten wij geen duidelijke samenhang met de specialisatie van de arts.

Tabel 13.3. geeft een overzicht van een vergelijking van huisarts en specialistpatienten op een aantal kermerken.

Wr zijn geen verschilien tussen de door ons ondervaagde huisarts- en specialistpatiënten voor wat betreft hun leeftijd, geslacht, de urbanisatiegraad van hun gemeente en hun verzekeringsvorm. Er is wel een zwakke anwijzing voor het feit, dat patiënten, aie voor hun andoening doox de specialist behandela worden - tegen de verwachting in - hoger zijn opgeleid dan huisartspatiënten. Het is niet onwaarschijnlijk, dat het hierbij gat om mondige patienten, die met een in hun ogen mogelijk eenwoudige huisartsenzorg geen genoegen nemen. verder onderzoek zal moeten witwijzen, of deze veronderstelling kan worden onderbouwd. Onze resultaten bevestigen in leder geval. niet het vermoeden, dat mondige patienten aandringen op meer doelmatige medische hulp en op een kortere behandelingsduur. (van de ven e.a., 1981.) 
Tabel 13.3. Verschlilen in persoonskenmerken tussen huisarts- en specialistpatienten (absolute aantillen xesp. ranggemiddelden)

\begin{tabular}{|c|c|c|c|}
\hline & $\begin{array}{c}\text { Irui.sartspatienten } \\
\qquad(N=30)\end{array}$ & $\begin{array}{l}\text { specialistpatienten } \\
\qquad(N=44)\end{array}$ & signiteicantie \\
\hline Leettija & 37.4 & 37.6 & $z=.03$ \\
\hline geslacht: man & 16 & 27 & \\
\hline vrouw & 14 & 17 & $x^{2}=0.47$ N.S. \\
\hline opleiding & 32.3 & 41.0 & $\begin{array}{l}z=1.77 \\
p<.04 \\
\text { (eenzijolg) }\end{array}$ \\
\hline \multicolumn{4}{|l|}{$\begin{array}{l}\text { urbanisatiegraad } \\
\text { (indeling C.B.S.) }\end{array}$} \\
\hline$A$ en $B$ & 14 & 21 & \\
\hline$c_{1-4}$ & 10 & 14 & $x^{2}=0.02$ N.S. \\
\hline$c_{5}$ & 6 & 9 & \\
\hline \multicolumn{4}{|c|}{ verzekerimgsworm } \\
\hline fonds & 23 & 29 & $\mathrm{x}^{2}=0.99 \mathrm{~N} . \mathrm{S}^{2}$ \\
\hline particulier & 7 & 15 & \\
\hline totaal & 30 & 44 & \\
\hline
\end{tabular}

1) zie hoofdstuk 14 paragraat 3.

13.4. Consumptiegeneigdheid van huisarts- en specialistpatiënten

In deze paragraaf vragen wij ons af, of huiaarts-en speclalistpatienten in hun consumptiegeneigdheld van elkatr verschilen. Wij willen dit weten in verband met onze tweede onderzoekshypothege betrefende de invloed van consumptiemgeneigaheid op lemanas feltelijke medische consumptie. In de volgende paragraaf gaan wij darop nader in, door deze apart voor huisarts- en specialistpatienten an de orde te steljen. Maar nu eerst de vraag: zijn huisartspatianten eerder tot medische consumptie geneigd dan patienten van specialis- 
ten, of is het ongekeerde het geval? En doen zich daarbij dan nog belangrijke verschllien voor de wje afzonderlijke geneigdheidscomponenten voor? Tabel 13.4. bevat hierop het antwoord.

Iabel 13.4. Verschilden in vilf geneigdheldscomponenten tussen huisarts- en specialistpatienten (Mann-Mhitney-u-toets, tweezijaigl

Eonsumpticis gene 1 gdhe 1 as componantien

vextrowwen in medische zarg vee1 + welnig tevredenhed met axts postief $*$ neglatie opvattingen over ziekte onprofes. $\rightarrow$ professiom. z lek tebleving slecht $\rightarrow$ goedy gedragsintentie sterk $\rightarrow$ gening

$\begin{array}{cc}\text { hularts - } & \text { epecialist- } \\ \text { patienten } & \text { patienten } \\ (N=30) & (\mathrm{N}=44) \\ \text { ranggem. } & \text { ranggem. }\end{array}$

$33.00 \quad 40.57 \quad 1.49 \quad$ N.S.

31.60

41.52

1.95

$p<.06$

34.40

39.61

1.02

N.S.

40.53

35.43

1.01

N. S.

36.22

38.32

0.42

N.S.

Over het algemeen zijn er geen significante verschillen tussen huisarts- en specialistpatiënten te vinden met betrek$\mathrm{king}$ tot hun consumptiegeneigdheid. zij verschilien in zwakke mate in een component: hulsartspatienten staan positiever tegenover hun (huis-) artis, dan specialistpatiënten tegenover hun specialist. Deze bevinding geeft aanleiding om hierop wat dieper in te gaan.

Wij herinneren eraan dat de geneigaheidscomponent attitude ten aanzien van de elgen arts uit twee delen is samengested Ten eerste bevat hij een schal met uitspraken over gedragingen van artsen tegenover te behandelen patiënten en ten tweede bevat hij een uiting van algemene (on) tevredenheid met de behandeling, die men van de elgen arts voor de hartandoening, de suikerziekte of de psoriasis krijgt. In tabel 13.5. is deze algemene uiting van (on) tevredenheid voor huisarts- en specialistpatienten apart weergegeven.

Het verschil tussen de twee groepen blijkt op grond van deze algenene satisfactie niet significant te zijn. Wel blijkt 
"Tabel 13.5. Mate van tevredenheid met behandelend arts" apart voor buisarts- en speclalistpatienten (absolute aantallen, toets van wilcoxony

\begin{tabular}{|c|c|c|}
\hline & $\begin{array}{l}\text { huisiats } \\
\text { patientem } \\
(N=30)\end{array}$ & $\begin{array}{l}\text { specialist- } \\
\text { pattenten } \\
(N=44)\end{array}$ \\
\hline buitengewo on tevreden & 8 & 14 \\
\hline zeer tewreden & 9 & 13 \\
\hline tevreden & 12 & 8 \\
\hline tamelijk tevreden & 1 & 3 \\
\hline niet zo tevreden & 0 & 6 \\
\hline gemiddela & 2.2 & 2.4 \\
\hline st. deviatie & 0.9 & 1.4 \\
\hline
\end{tabular}

dat de specialistpatiënten verdeeld zijn in hun mening over de arts, meer dan dat bij huisartspatienten het geval is.

Valt er meer te zeggen over de redenen tot ontevredenheid van specialist-patiënten? In hoofdstuk. 6 is uiteengezet, dat de onderscheiden componenten van consumptiegeneigdheid nogal globale maten aangeven voor bepaalde opvattingen, attituden en gedragsintenties. Eventueel te onderschelden dimensies binnen die opvattingen en attituden zijn buiten beschouwing gelaten. Nu wij verschillen tussen huisarts- en specialistpatiënten bezien is het echter interessant, om deze dimensies binnen de attitude ten aanzien van de arts nader te onderzoeken. Men kan dan een preciezer beeld verkrijgen van de wijze warop patienten tegen hun huisarts resp. hun specialist aanlijken.

Welke dimensies zijn binnen de attitude ten aanzier van de eigen arts te onderscheiden? om hierin inzicht te kijgen zijn de twalif uitspraken over het gearag wan de elgen arts aan een factoranalyse onderworpen (zie bijlage 12). De geroteerde structuur levert vier duldelijk van elkadr te onderscheiden en goed te interpreteren factoren op, sanengesteld ilt onderstaande items. Daarbij is de interpretatie mede gebaseerd op de bevindingen van Cassee (1973), Nievaata (1976) en Van Loon en Schmidt (1977). 
Factor 1: cominumatief optreden

mijn (huis) arts

- stelt je op je gemak als je met hem praat

- behandelt me niet als nummer

- heeft tijd voor me als $1 k$ hem raadpleeg

- is bereid om naar je moeilijkheden te Iuisteren

De viex uitspraken wijzen op een door de patient-respondent gepercipieerde ontspannen sfeer tijdens het doktersconsult. Cassee (1973) spreekt in dit verband van "het aanmoedigen van een oper communlatie met de (huis)arts, die uit het gedrag blijkt" (p. 32).

\section{Eactor 2: informatief optreden}

mijn (huis)arts:

- vertelt me precies hoe ernstig het is

- praat met me over andere dingen dan over mijn ziekte alieen

- legt me uit warrom hij lets op een bepaalde manier doet

- prat met me over andere dan medische problemen

Deze factor bevat items die angeven, dat de arts informatie van verschillende aard met de patiënt uitwisselt. Volgens de resultaten van Van Loon en Schmidt (1.977) kwam deze dimensie als de belangrijkste van de arts - patiënt relatie naar voren. De betekenis ervan ligt dicht bij de dimensie "cognitief optredem" (vooral gezien de formulering'van de items 7 en 10 en de relatief hoge factorladingen vam de 1 tems 4 en 9 ook op deze factor), mar is daarvan toch duldelijk te onderscheiden.

Factor 3: instrumenteel optreden

mign (buis) arts

- stat exop, dat je precies doet wat hij zegt

- schrijft je natwkeurig voor wat je moet doen

Evenals de hierondex te bespreken factor 4 is deze factor met sliechts twee items in feite ontoerelkend om als aparte dimensle van de attitude tegenover de eigen arts in anmerking te 
komen. Daartegenover staat, dat de twee items $21 \mathrm{ch}$ door hun hoge lading op alleen deze factor dujdelijk van alle andere items onderscheiden en dat zij goed interpreteerbar zijn. 2ij wijen op "de zekerheid warmee de arts . "optreedt. Duldelljk en beslist aangeven wht de patient moet doen, zonder caarbij enige aarzeling te tonen" (Cassee, 1973, p. 33).

Factor: 4: afwerend optreden

mijn (huis) arts

- is nogal onzeker in zijn optreden

- is nogal zakelijk

De twee items van deze factor geven een gepercipieerde sociale afstand ten opzichte van de arts aan. Cassee noemt het gedrag van de arts, dat hiermee wordt gekenmerkt "afwerend optreden". Wooral ten aanzien van deze dimensie is bij de interpretatie grote voorzichtigheid geboden. Tabel 6.3. laat zien, dat de items nawwelijks discrimineren en een scheve verdeling van antwoorden opleverden.

zien huisartspatiënten het optreden van hun arts in termen van communicatie, informatie-uitwisseling, duidelijkheid (meer instrumenteel) en ervaren afwerend optreden nu anders dan specialistpatiënten hun arts zien? Uit tabel 13.6. blijkt, dat de beide groepen slechts een van de vier onderscheider dimensies verschillend ervaren: huisartsen worden door hun patienten als informatiever gekarakteriseerd dan specialisten. Ten aanzien van het instrumentele, het communicatieve en het afwerend optreden bestaat er geen signiflcant onderscheid.

Tabel 13.6. Verschillen tussen huisarts- en specialistpatienten in de wijze waarop zij het optreden van hun arts ervaran (Mann-whitney-toets, tweezjaig)

\begin{tabular}{|c|c|c|c|c|}
\hline & $\begin{array}{l}\text { huisarts- } \\
\text { patienten } \\
\text { (gen . rang. } \\
\text { nir; } N=30 \text { ) }\end{array}$ & 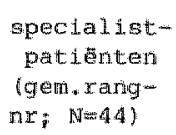 & $z$ & sign. \\
\hline communicatief & 33.15 & 40.47 & 1.45 & N.S. \\
\hline informatief & 31.13 & 41.84 & 2.11 & $p<.03$ \\
\hline instrumenteel & 32.00 & 41.25 & 1.83 & N.S. \\
\hline atwerend & 37.73 & 37.34 & 0.08 & N.S. \\
\hline
\end{tabular}


Toch wjzen drie van de wier resultaten in de richting van een relatief negatieve wardering geuit door specialistpatienten. Zij zien het gedrag van hun arts-specialist als minder communicatief, minder informatief en minder instrumenteel dan huisartspatianten dat zien. Deze op zichzelf niet significante verschillen leiden gezamenlijk tot de relatief negatieve attitude ten aanzien van specialisten.

Met andere woorden: de relatief negatieve attitude ten aanzien vin specialisten kont miet voort uit specifieke kritiek wan de patiënten met betrekking tot fen bepaald kenmerk van hun gedrag. Deze werspiegelt verelex een negatieve beordeling wan het algemene optreden van de specialisten tegenover de hier onderzochte chronische patienten. Wanneer men in aanmerking neemt, dat de meeste patiëten gezien hun zlekteduux hun behandelend specialist al vrij lang kennen, dan mag men aannemen, dat dit oordeel op meer berust dan op een vluchtige indruk. Als men deze conelusie beziet tegen de achtergrona van onze bevinding, dat specialistpatiënten niet ernstiger ziek zijn dan huisartspatienten, dan geeft zij steun aan de pleidooien ten gunste van de niet-specialistische eerstelijins-zorg.

13.5. Medische consumptie, consumptiegenelgdheid en het lekennetwerk van huisarts-en specialistpatiënten 13.5.1. Inleiding

In hoofdstuk 7, paragraaf 7.2. werd voor alle respondenten tezamen bezien, welke invloed hun consumptiegeneigdheid heeft op het aantal malen dat zij hun huisarts consulteren. De concluste luidde, dat 20 , varlantie van de raadpleegfxequentile kon worden verklaard, nadat de invloed van het wantal woorgeschreven controles was geẻlimineerd. In het geval waarin geen rekening werd gehouden met de controlenoodzaak, steeg dit percentage tot 27,8 .

Wij willen nu weten, hoe dit beeld er apart woor hulsarts- en specialistpatiénten uit komt te zien. Dit om de relatie tussen consumptiegenelgaheid en medische consumptle wat meer in detall te achterhalen. Alvorens daarop in te gaan zul- 
Ien wj echter de samenhang tussen voorgeschreven controles en feltelijke medische consumptie van huisarts- en speolalistpatienten. wat meer uitalepen. In paragraaf 13.5.3. besteden w1 dan nog in het kort aandacht aan de rol die persoonskenmerken bij de medische consumptie spelen. In paragraf 13.5 .4$. en 13.5.5. komt ten slotte de elgenlijke probleemstelling van deze paragraaf an de orde. Wij vragen ons daarin af: welke variantie in het aantal specialist-consulten kan voor specialistpatienten door hun consumptiegeneigdheid worden verklaara? Is de invloed van de consumptiegenelgdheid van deze patienten even groot, als deze hun huisarts raadplegen? $\mathbb{E}$ tenslotte: In welke mate worden huisartspatiënten door hun consumptiegeneligdheid belnvloed, als zij hun huisarts consulteren?

\subsubsection{Voorgeschreven controles en medische comsumptie}

In het voorgaande is de invloed van consumptiegeneigdheid op het raadplegen van de arts telkens (medel bezien met ultschakeling van het antal voorgeschreven controleconsulten. Daarbij merkten wij op, dat deze werkwijze in ons radeel werkt als wij de huisartsconsulten van alle respondenten bezien, omdat controles veelal door de specialist zullen worden uitgevoerd. Nu wij huisarts- en specialistpatiënten afzonder$1 \mathrm{ijk}$ bestuderen is het $\mathrm{zinvol}$, de relaties tussen medische consumptie en voorgeschreven controlefrequenties voox beide groepen apart preciezer te achterhalen. Wij stelien hiermee de vraag naar de beslissingsvrijheid an de orde: in welke mate is de patient vrij om zelf zijn aantal huisarts- of specialistconsulten te bepalen; lat de controlenoodzaak hem hiervoor nog wel de ruimte? Wij gaan er hierbij vanutt, dat de patiënt woorgeschreven controles inderdaad laat ultvoeren. De antwoorden op de desbetreffende vraag in de interviews rechtvaaraigen deze anname voor het merendeel var de respondenten: slechts zeven van hen (arie psoriasis- en vier sulkexpatienteng zeggen de contrale wel eens over te slan.

In bijlage 13 zijn arie tabellen opgenomen warin het aantal huisarts-resp. specialistconsulten van de twee groepen per woorgeschreven controlefrequentie is weergegeven. De samenhang extussen is duidelijk, mar is deze zo sterk, dat van 
beslissingsvrifheld geen sprake meer kan zijn? En zijn er wat dat betreft nog verschilen tussen hudsarts- en specialistpatienter?

De correlatiecoëflcienten ${ }^{1}$ tussem belde variabelen Iaten de volgende conclusies toe (tabe1 13.7.): de samenhang tussen controlenoodzaak en feitelijke medische consumptie is niet zo groot, dat daardor de besilssingsvrijheid volledig afwezig 18 .

Tabel 13.7. Samenhang tussen controlenoodzaak en feitelijke raadpleegfrequentie (product-moment correlatie; zlie noot 1 )

specilalistpatienten: aantal specialistconsulten

\begin{tabular}{ll}
$r$ & sign. \\
\hline .38 & $p<.01$ \\
.37 & $p<.01$ \\
.30 & $\mathrm{p}<.05$
\end{tabular}

Voorts blijkt dat de versohilien tussen de drie graepen niet spectaculair zijn. De correlatie tussen huisartscontacten en controlenoodzaak bij specialistpatienten roept de vraag op of deze patienten voor een specialistconsult i.V.m. de aandoening over een verwijsbrief van de huisarts moet beschikken. Om hierin enjg inzicht te krijgen is nagegaan, waarom specialistpatienten de huisarts consulteren. Als dit voor het merendeel der gevalien in verband met de aandoening in kwestie 1s, dan is het aannemelijk, dat een deel van deze consulten in een verwijzing resulteert. Als daarentegen een andere reden worat genoemd, dan is dit warschijnlijk niet of minder het gewal. Van de 17 specialistpatiënten, die in drie maanden minstens eenmal bij de huisarts waren geweest, gaven 12 te kennen, dat niet in verband met het hartinfarct, de diabetes of psoriasis gedan te hebben. Hun besllssingsviljheld bij een bezoek aan de hudsarts is dus groter dan uit tabel 13.7. bij jkt..

De bevindingen uit deze paragraaf zijn voor de verdere analyse van tweeerlei betekenis. In de eerste plats moet men bedenken, dat de controlenoodzaak hooguit 15 s variantie van de raadpleegfrequentie bij do hier onderscheiden patienten verklaart. In de tweede plats lifkt het zinvol, om naast de 
specialistconsulten ook de huisartsconsulten van specialistpatiëten in de beschouwing te betrekken. Het is niet annemelijk, dat deze direct in elkars verlengde liggen. zij hebben vermoedelijk betrekking op verschillende klachten en zijn het gevolg war verschillende beslissingsprocessen van de patient.

\subsubsection{Medische consumptie en persoonskenmerken}

Wij hebben nu wat meer zicht op de relatie tussen voorgeschreven controlefrequenties en medische consumptie. Alvorens de invloed van de consumptiegenelgdheid op het radpleeggedrag van huisarts- en specialistpatiënten te bezien, besteden wij eerst in het kort aandacht aan het verband tussen persoonskenmerken van de patiënt en zijn bezoeken aan de arts. Dit heeft in hoofazaak een statistische reden. In hoofdstuk 7 en in hoofastuk 11 werd er al op gewezen, dat ons material. in feite niet voldoet aar de eisen, die toepassing van geavanceerde parametrische technieken eraan stellen. Onze overwegingen, om de invlaed van consumptiegeneigdheid op medische consumptie ondanks dit bezwaar toch mede met behulp van regressie-analyses na te gaan, hebben wij daar uiteen gezet.

De vraagsteling die nu aan de orde is, platst ons voor een extra probleem. Wij moeten nlet alleen slechts een deel van onze steekproef in de analyse betrekken, maar wij willen tevens een zo zuiver mogeljjk beeld krijgen van de invloed van consumptiegeneigdheid op twee vormen van medische consumptie. Hiervoor zal men ook bepalde persoonskenmerken in beschouwing willen nemen, alvorens conclusies ten aanzien van de roll van consumptiegeneigaheid te trekken. Dit omdat bekend is, dat leeftijd, geslacht en oplelding belangrijke determinanten van medische consumptie zijn. Naamate men achter meer variabelen in de regressie-analyse betrekt, worden de uitkomsten bij een klein aantal onderzoekseenheden al snel onbetrouwbar.

Wij berekenden daarom eerst woor hulsarts- en specialistpatiërten apart nulde-orde correlaties tussen indicaties voor medische consumptie en enkele relievant te achten persoonskenmerken. Kenmerken, die significant met medische consumptie 
samenhangen zullen in de regressidanalyse worden opgenonen. De overtge pexsoonskemmexken blijven daarblj dan verder buiten beschouwing.

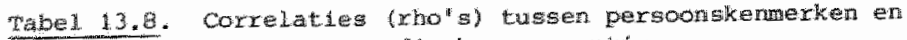
women wan medilsche consumptie

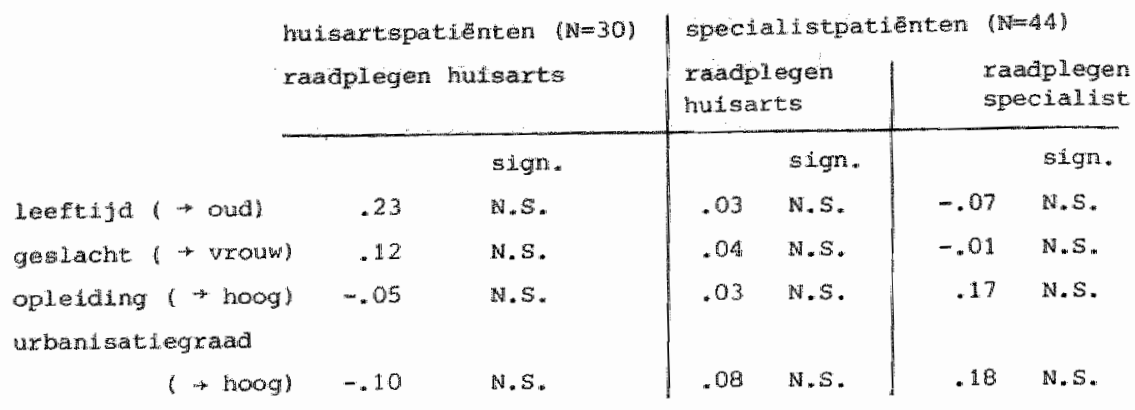

Tabe 1 13.8. toont aan, dat geen van de onderzochte samenhangen significant is. Deze ultkomsten geven aanleiding, on de volgende analysefase zondex persoonskenmerken uit te voeren.

13.5.4. Medische consumptie van specialistpatiënten

Wij stellen dus nu de vraag: welke rol speelt de consumptlegeneigaheid van specialistpatienten bij hun medische consumptie? Daarbij zal de rol van de voorgeschreven controles telkens worden geẻlimineerd. Tabel 13.9. geeft een antwoord voor het aantal specialist-consulten.

Het resultaat is interessant: de vijf consumptiegeneigdheldscomponenten verklaren slechts 7 a 8 variantie in de frequentle, warmee men de speclalist consulteert (zonder dat dit warschijnlijk voorgeschreven consulten betrof). Dit percentage is veel lägex dar het percentage dat de geneigdheidscomponenten in het aantal hulsartscontacten van alle Iespondenten verklaarde (vergelijke tabel 7.5.). Het is bovendien niet slgnificant, evenmin ais het totale percentage van 22, at door geneigdheid dn controlenoodzak wordt verklaard. Met andere worden: noch de controlenoodzaak, noch de consumpthegeneigdheld, zijn voldoende om ook maar een significant 
Tabel 13.9. De mate waarin de viff geneigaheidscomponenten het aantal specialistconsulten verklaren (stapsgewijze regressieanalyse, gezuiverd woox yoorgeschreven controles, speciarlistpatienten: $N=44$ ) 1 )

\begin{tabular}{|c|c|c|c|c|}
\hline $\begin{array}{l}\text { onatharkelijke } \\
\text { variabelen }\end{array}$ & $\begin{array}{l}\text { toegevoegde } \\
\text { verkl. variantie }\end{array}$ & $\begin{array}{l}\text { partide regr.- } \\
\text { coefficient ( } \mathrm{B} \text { ) }\end{array}$ & $F$ & sign. \\
\hline controlenoodzaak & 14.6 & .33 & 3.5 & $p<.05$ \\
\hline $\begin{array}{l}\text { gedragsintentie } \\
\text { (sterk - gering) }\end{array}$ & 5.9 & .25 & 2.67 & $\mathrm{p}<.05$ \\
\hline $\begin{array}{l}\text { vertrouwen in } \\
\text { medische zorg } \\
\text { (veel } \rightarrow \text { weinig) }\end{array}$ & 1.7 & -.12 & 0.43 & N.S. \\
\hline $\begin{array}{l}\text { attitude t. } a_{n} \psi_{*} \\
\text { arts (pos. } \rightarrow \text { neg.) }\end{array}$ & 0.1 & -.04 & 0.07 & N.S. \\
\hline $\begin{array}{l}\text { opvattingen ower } \\
\text { zlekte (onprofess. } \\
\text { - professionedi }\end{array}$ & 0.0 & .02 & 0.02 & N.S. \\
\hline $\begin{array}{l}\text { ziektebeleving } \\
\text { (slecht } \rightarrow \text { goed) }\end{array}$ & - & -.02 & 0.01 & N.S. \\
\hline $\begin{array}{l}\text { totaal } \underline{r}^{2} \text { dowr } \\
\text { cons.geneigdhe:id }\end{array}$ & 7.8 & & 0.63 & N.S. \\
\hline totan $1 r^{2}$ & $22.4 \%$ & & 1.79 & $\mathrm{~N} . \mathrm{S}$. \\
\hline
\end{tabular}

1) Bijlage 14 bevat de matrix van product-moment correlaties

deel van het aantal specialistconsulten van specialistpatiënten te verklaren.

Woorts valt ap, dat julst een geringe gedragsintentie significant tot deze verklaring bijdraagt. De in het voorgaande zo belangrijk gebleken ziektebeleving speelt daarentegen een volleaig ondergeschikte rol. Dit is moellijk in te zien. Men moet hieruit warschijnlijk de conclusie trekker, dat het raadplegen van de (eigen) specialist het gevolg is van en geheel andersoortig beslissingsproces, dan het radplegen van de huisarts.

Hebben kenmerken van het lekennetwerk daarbij nog een bepalde $\mathbb{1}$ avioed? Wij kozen voor de beantwording van deze vraag enkele kenmexken, die in hoofdstuk 12 op de medische consumptie van invloed bleken te zijn, onder toevoeging wan 
de attitude, die de meest-betrokkene er ten anzien var de specialist op nahoudt. Hierwor kwam de overeenkomstige attitude van de patiant lu dit werband als belangrijk nar voren, reden watrom wij nu nagan, of die attitude van de lekenadviseur het aantal specilistcontacten befnuloedt.

Tabel 13.10. lat zien, dat dat inderdaad het geval is, max dan wel in een onverwachte richting een positieve attitude van de eerste lekenadviseur ten anzien van de specialist hangt samen met relatief weinig specialistconsulten van de patient. Wij kumen hiervoor geen bevredigende interpretatie aradragen.

De overige netwerkkenmerken spelen een ondergeschikte (niet-significante) rol en het totaalresultaat is niet significant. Wij concluderer derhalve, dat de consumptiegeneigd-

Tabel 13.10. De rate warin bepalde netwerkkennerken het aantal spectalistconsulten verklaren (stapsqewi.jze regressieanalyse, specialistpatienten: $N=44$ ) I)

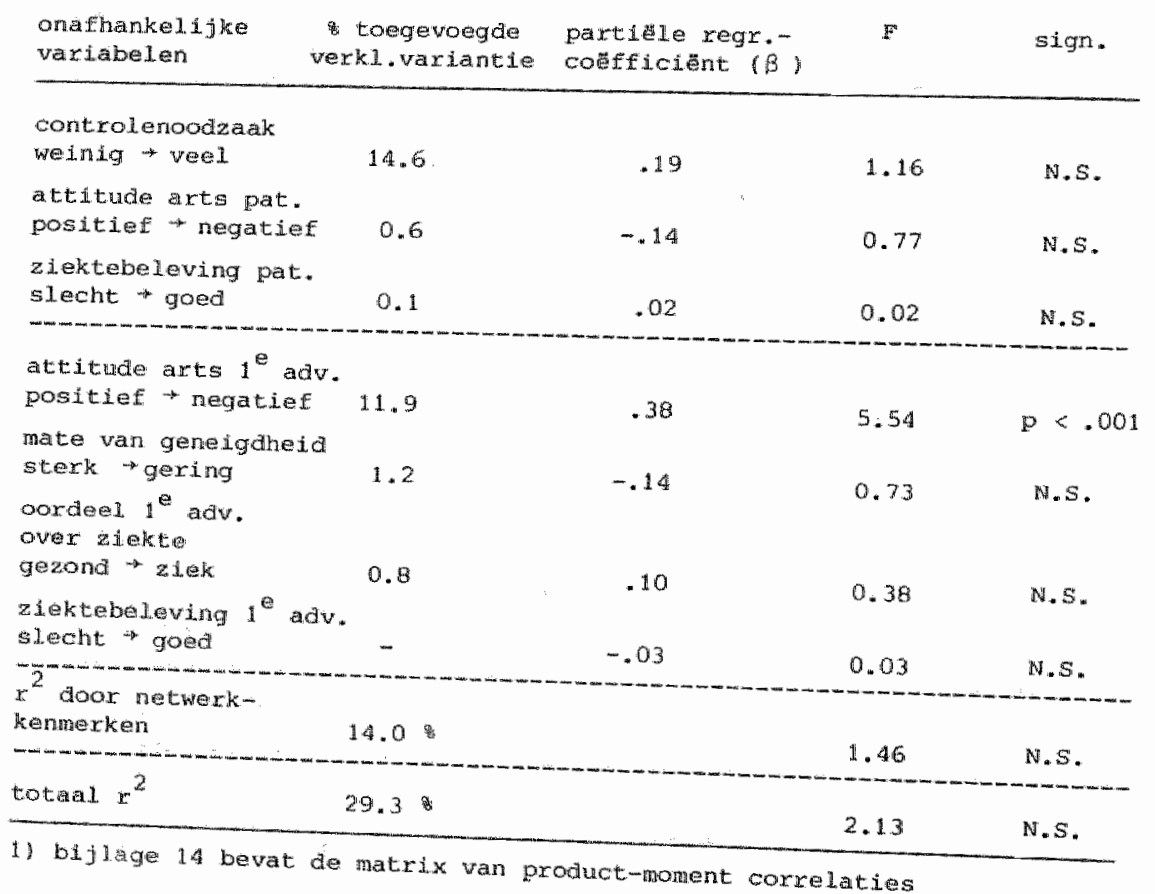


held van specialistpatienten en hun lekenadviseurs en voor ons moeilijk te begrijpen max overigens niet signifioante rol speelt als deze hun specialist consulteren.

Kunnen wij meer zeggen over de invloed van consumptiegenelgaheid van specialistpatiênten bij hun huisartsconsulten? In tabel 13.11. is een antwoord op deze vraag te winden. Na de controlenoodzaak voegen de vijf geneigdheldscomponenten tezamen 14 verklaarde variantie toe in het raadplegen van de huisarts. Daarbij speelt de zlektebeleving van de patient weer wel een rol.

Dit is verbazend omdat uit paragraaf 13.5 .2 . bleek, dat een deel van deze consulten betrekking heeft op iets anders dan de andoening in kwestie. En toch heeft juist de wijze warop men het hebben van een hartinfarct, suikerziekte resp. psoriasis beleeft, de grootste invloed bij het raadplegen van de huisarts?

Tabel 13.11. De mate warin de wij genelgaheidscomponenten Met aantal huisartsconsulten verkiaren (stapsgewijze regxessieanalyse, gezuiverd poor, voorgeschreven controles, spectalistpatienten: $n=44$ ) 1 )

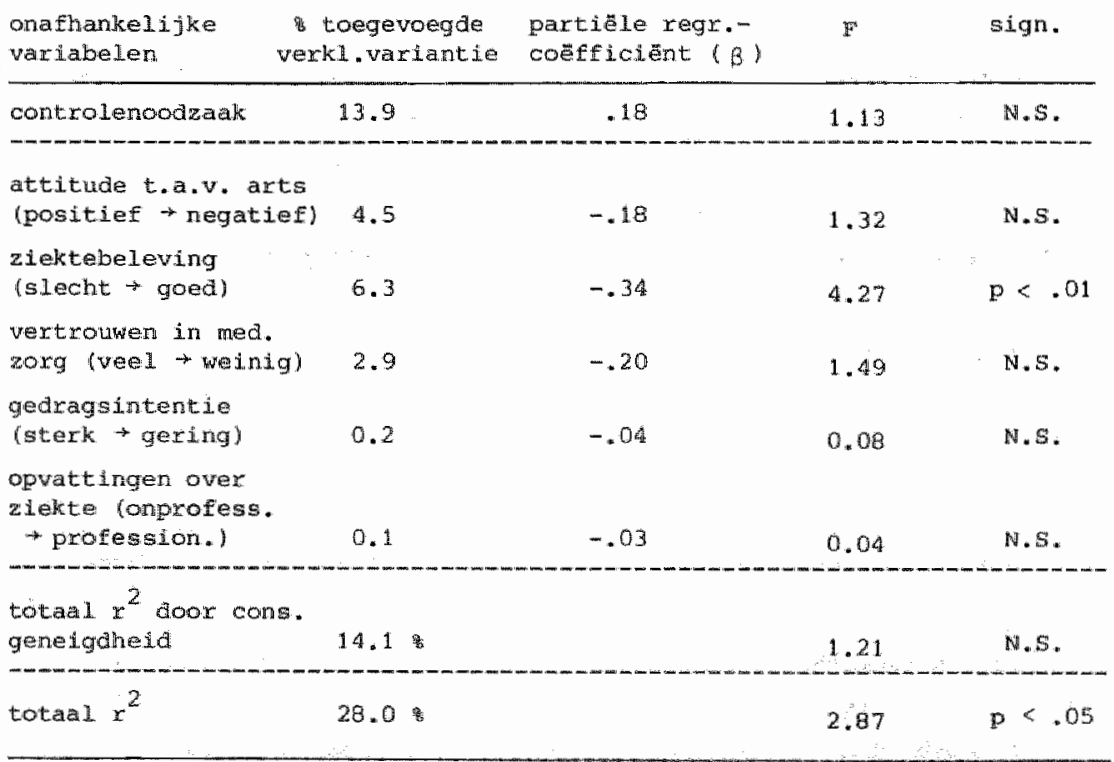

1) bijlage 14 bevat de matrix van product-möment correlaties 
Hiervoor zijn vermodelijk twee redenen an te voeren. In de exste plates is het mogelijk, det de in de interviews gegeven reden voor met huisartsenconsult niet geheel juist was. Men zei weliswad, de huisarts woor iets anders te hebben geraadplegd (men is immers "specialist-patient"), maar dit consult had toch het - mogelijk onderliggende en niet bewute - doel, de arndoening in kwestle ter sprake te brengen. In de tweede plats is het niet onwarschijniljk, dat de variabele "ziktebeleving" meer indiceert, dan de beleving van de andoendng in kwestie. Het zich ongerust maken over deze ziekte, het zich ziek vinden etc. zou op een nogal algemene attitude ten aanzien van ziekte en gezondheid kunnen wijzen. De in hootdstuk 6 en 7 onderzochte mar niet gevonden verschillen in ziektebeleving tussen de drie patiëntencategorieen ondersteunen dit vermoeden.

Hoe het aok $z i j$, de vijf geneigdheidscomponenten van specialistpatienter spelen samen een relatief geringe rol bij hun beslissing, de bulsarts te raadplegen. De uitkomst $\left(r^{2}=\right.$ 14,1 ;) is ntet sighificant, ook al is zif bevredigender dan het hiervoor beschreven resultat $\left(x^{2}=7,8\right.$ ) bij specialistconsulten.

Wat valt or over de invloed van netwerkkenmerken hierbij te zeggen? Tabel 13.1.2. geeft een overzicht. Het valt op, dat de ziektebeleving van de eerste lekenadviseur deze invloed voox een groot deel bepalit: deze voegt - radat de ziektebeleving van de patiënt is ingevoerd - nog eens 10 g verklaring van de variantie in het aantal huisartscontacten toe. De invloed van alle netwerkkenmerken tezamen is niet sigmificant mar het totalresultat $\left(x^{2}=39,2\right.$ is bevredigend te noeran.

\subsubsection{Medische consumptie van huisartspatiënten}

Uit het woorgande is gebleken, dat de beslissingsvijheid om de huisarts te raadplegen - gezien de samenhang tussen de voorgeschreven controlefrequentie en het feitelijk aantal consulten - van huisartspatienten nogal groot is. voorts is bekend, dat de invloed van bepalde persoonskenmerken op het radplegen wan de hulsarts ook woor deze groep 
Tabel 13.12. De mate waarin bepalae netwerkkenmerken het antal huisartscontacten van speclalistpatiuten yerklaren (stapsgewijze regressie-analyse, $N=44$ )

\begin{tabular}{|c|c|c|c|c|}
\hline $\begin{array}{l}\text { onafhanke lif ke } \\
\text { wariabelen }\end{array}$ & $\begin{array}{l}\text { toegevoegde } \\
\text { vexkl variantie }\end{array}$ & $\begin{array}{l}\text { partibie regr.- } \\
\text { eofficient ( } B \text { ) }\end{array}$ & $\mathrm{F}$ & signi. \\
\hline $\begin{array}{l}\text { controlenoodzaak } \\
\text { weinig } \rightarrow \text { weel }\end{array}$ & 13.9 & .12 & 0.59 & $\mathrm{~N}_{*} \mathrm{~S}$. \\
\hline $\begin{array}{l}\text { attitude arts pat. } \\
\text { positief } \rightarrow \text { negatié }\end{array}$ & 4.5 &.- .15 & 0.95 & N.S. \\
\hline $\begin{array}{l}\text { ziektebeleving pat. } \\
\text { slecht } \rightarrow \text { goed }\end{array}$ & 6.3 & -.08 & 0.23 & N.S. \\
\hline $\begin{array}{l}\text { zlektebe } 1.1 \text { adv. } \\
\text { slecht } \rightarrow \text { goed } \\
\text { ocrdeel } 1^{e} \text { adv. } \\
\text { over ziekte } \\
\text { gezond } \rightarrow \text { ziek }\end{array}$ & 10.2 & -.36 & 5.17 & $p<.001$ \\
\hline $\begin{array}{l}\text { mate van genelgd- } \\
\text { helid } \rightarrow \text { sterk gering } \\
\text { attitude arts } 1^{\text {e }} \text { adv. } \\
\text { positief } \rightarrow \text { negatief }\end{array}$ & $\begin{array}{ll}9 & 1.7 \\
& 0.3\end{array}$ & -.14 & 0.86 & $\begin{array}{l}\text { N.S. } \\
\text { N.S. }\end{array}$ \\
\hline $\begin{array}{l}\mathrm{r}^{2} \text { door netwerk- } \\
\text { kenmerken }\end{array}$ & 15.4 & & 1.64 & N.S. \\
\hline totaal $x^{2}$ & 39.2 . & & 3.32 & $p<.01$ \\
\hline
\end{tabular}

1) bijlage 14 bevat de matrix van product-moment correlaties

verwarloosbaar klein is. Welke rol speelt nu de consumptiegeneigaheid van de patient en welke die van zijn lekenadviseurs?

Tabel 13.13. Lat zien, dat de vijf geneigdheidscomponenten van de patiënt samen 48 variantie verklaren in het aantal huisartscontacten van hulsartspatienten. Daarbij is de invloed van de controlenoodzaak wederom geelimineerd. Dit resultat is duldelijk significant. Ook de bijdragen van de afzonderlijke componenten zijn duidelijker, dan bij de voorgaande analyses. Drie van de wif componenten hebben een signiticante invloed. Het valt op, dat vooxal een sterke gedragsintentie en een positieve attutude ten anzien van de arts belangrijk zijn in deze. Controlenoodzak en consumptiegenelgaheld verklaren samen 57 varlantie! 
Tabel 13.13. De nate warin de vijf genelgdheldscomponenten het antal huisartsconsulten van huisartspatienten $(M=30$ ) verklaren (stapsgetifye regresise-analyse, gezul werai roor controlenoodzaak)

\begin{tabular}{|c|c|c|c|c|}
\hline $\begin{array}{l}\text { onafhankel joke } \\
\text { vabelem }\end{array}$ & $\begin{array}{l}\text { tomevongale } \\
\text { verkl.vaxiantie }\end{array}$ & $\begin{array}{l}\text { partiele regr.- } \\
\text { coefficient }(\beta)\end{array}$ & $F$ & sigm * \\
\hline controlenoodzaak & 9.0 & .28 & 3.24 & $p<.05$ \\
\hline $\begin{array}{l}\text { gedragsintentie } \\
\text { (stexk } \rightarrow \text { gering) }\end{array}$ & 2.2 .7 & -.54 & 14.33 & $p<.001$ \\
\hline $\begin{array}{l}\text { attltude t.a.v. } \\
\text { artsi }(\text { pos. } \rightarrow \text { neg. })\end{array}$ & 16.9 & -.55 & 10.67 & $\mathrm{p}<.00$ \\
\hline $\begin{array}{l}\text { ziek tebeleving } \\
\text { (slecht + goed) }\end{array}$ & 7.7 & -.31 & 3.59 & $p<.05$ \\
\hline $\begin{array}{l}\text { vertronwen in } \\
\text { medische zorg } \\
\text { (veel t welnig) }\end{array}$ & 0.4 & .06 & 0.15 & N.S. \\
\hline $\begin{array}{l}\text { opwattingren over } \\
\text { zlekte (onprofess. } \\
\text { w profegsion.) }\end{array}$ & 0.2 & .06 & 0.15 & N.S. \\
\hline $\begin{array}{l}\text { totalal } x^{2} \text { door } \\
\text { cons.gemeigdheid }\end{array}$ & $48.0 \mathrm{~g}$ & & $4 \cdot 43$ & $p<.01$ \\
\hline $\operatorname{totaa} x^{2}$ & 57.0 & & 5.09 & $p<.01$ \\
\hline
\end{tabular}

1) bijlage 14 bevat de matrix van product-moment correlaties

Tabel 13.14. toont aan, dat ook hier de ziektebeleving van de eerste adviseur een relatief grote mar toch geen significante additionele rol speelt. De hiler bestudeerde netwerkkemmerken voegen boven de controlenoodzaak en wee belangrijke geneigdheidscomponenten van de patient ruim 15 gariantieverklaring toe. Dit resultat is niet significant. Wij moeten op dit punt concluderen, dat de invloed van de consumptiegeneigdheid van hulsartspatienten op hun medische consumptie belangrijker ls dan die van de netwerkkenmerken.

\subsection{Tot besluit}

In dit hoofastuk hebben wij onderzocht op welke punten en 1 helke mate de bij dit onderzoek betrokken huisarts- en speciel1stpatiënten ran elkaar verschillen (paragrafen 13.2., 
Tabel 13.14. De mate waarin bepaalae netwerkkenmerken het aantal huisartisconsulten van huisartspatienten $(\mathbb{N}=30$ ) werklaren (stapsgewijze regressie-analyse) i)

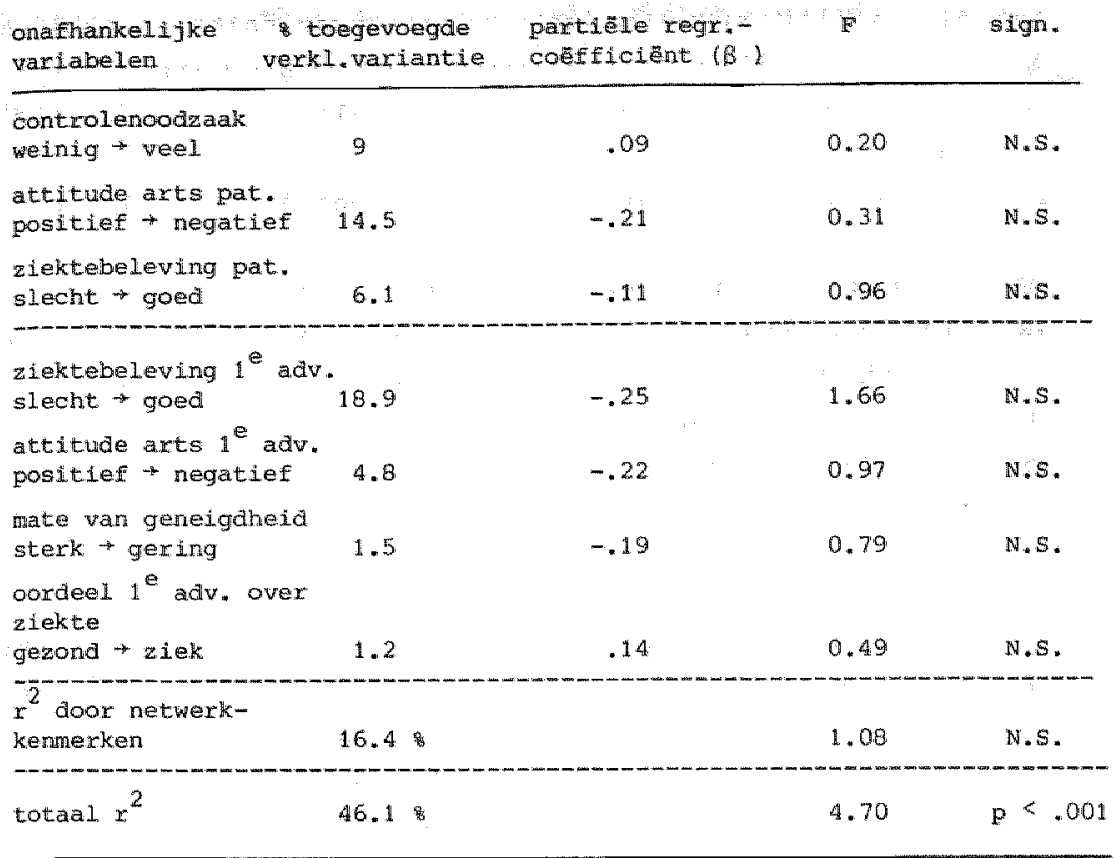

1) bijlage 14 bevat de watrix ran product-moment correlaties

13.3. en 13.4.\%. Tegen de verwachting in vonden wij slechts een beperkt aantal verschilpunten.

vervolgens gingen wij na, welke rol de consumptiegeneigdheid speelt bij de feitelijke medische consumptie van beide groepen (paragraaf 13.5.). Om hiervan een zo zuiver mogelijk beeld te krijgen, onderzochten wij eerst de betekenis van het aantal voorgeschreven controles en van enkele persoonskenmerken voor die medische comsumptie. Met de resultaten van de eigeniljke analyse (paragrafien 13.5.4. en 13.5.5.) kunnen wij nu de bevindingen uit hoofastuk 7 nader specificeren.

Consumptiegenelgdheid speelt niet bij alle vormen van medische consumptie een even grote rol. De rol is verwarioosbaax klein bij de Erequentie wamee specialistpatienten hun specialist raadplegen. Ook de netwerkkenmerken spelen daarbij een ondergeschikte rol. Wij concludeerden dat het raadplegen 
van de speclalist vernoedelijk het gevolg is van een nogal moell1jk te begrijpen beslissingsproces.

De rol van de consumptiegenelgaheld wordt groter bij het antal huisartsconsulten van specialistpatienten. Daarbij kon bovendien een addttonele invloed van een netwerkkenmerk nI. de zlektebeleving van de eerste adviseur - worden geconstatererd.

De meest duidelijke invloed van consumptiegeneigdheld is echter te vinder blj hulsartspatienten en hun bezoeken aan de huisarts. Een groot deel $\left(x^{2}=48\right.$ g) van de variantie in deze vorm van medische consumptie wordt daar door de consumptiegeneigaheid van de patient verklaard. ook hierbij speelt de ziektebeleving van de eerste adviseur een rol "echter nu zonder dat deze invloed een bevredigend significantieniveau bereikt.

Deze uitkonsten $z$ ijn warschijnlijk te interpreteren tegen de achtergrond van de sociale afstand tussen lekensystemen en professioneel. systeen (Freidson, 1961). Men mag veronderstellen, dat patiënten en hun lekenadviseurs de sociale afstand ten opzichte van een medisch specialist groter ervaren dan ten opzichte van de huisarts. Dit geldt te meer voor patiënten, die zelf zeggen door de aandoening door de huisarts behandeld te willen worden. De huisarts is tegelijk arts van andere leden van het netwerk, de drempel om zijn hulp in te roepen is doorgaans geringer, dan de drempel die bij het consulteren van de specialist overwonnen moet worden. onze uitkomsten wijzen erop, dat de geneigdheid tot het inroepen van medische hulp afneemt, naamate de gepercipieerde sociale afstand ten opzichte van de arts groter is. De centrale rol. die de huisarts in de eersteljns-gezondheidszorg in Nedexland speelt brengt met zich mee, dat de lnvioed van consumptiegeneigdheld op het imroepen van $z$ inn hulp relatief groot 15 .

\section{NOOT BII HOOFDSTUK 13}

1) Belde viriabelen bevaten vele gelifke warnemingen " ties"j. Rangcorrelaties zijn hiervoor exg gevoelig. Wij kozen in dit geval derhalve voor de (parametrische) product moment corredatie-coefficient, om de mate van samenhang te bepalen. 
Hoofdstuk 14. Consumptiegeneigdheid en overige vormen van medische consumptie

\subsection{Veel gebruik wan (verschillende) gezondheidszorg- voorzieningen}

Vooral chronische patienten kunnen met verschiliende gezondheidszorgvoorzieningen in contact komen. Psoriasispatienten maken bijvoorbeeld soms gebruik wan een zomnebank, hartinfarctpatienten moeten veelal een tjo lang naar de trombosedienst en diabetici bezoeken wellicht wel eeris een dietiste. Deze en andere vormen van medische consumptie kwamen tijdens het interview ter sprake. "Nu verschillen de genoemde voorzieningen uiteraara per patiëntencategorie terwijl er binmen elke patiëntencategorie telkens mar enkele mensen $i j n$, die ervan gebruik makten. Dit bemoeilijkt de analyse.

on toch enig inzicht te krijgen in de invioed van de consumptiegeneigdheld op het gebruik van andere voorzieningen dan huisarts en specialist, besloten wij onze aandacht te richten op veel contacten met verschillerde voorzieningen tegelijk. Daarbij veronderstellen wij het volgende. voor elk contact met de besproken verschillende vormen van zorg 1 s waarschijnlijk wel een duidelijke reden aan te geven. Als echter blijkt, dat lemand veel instanties radpleegt, dan kan dat een achterliggende oorzak hebben. Het is mogelijk, dat hij "van het kastje naar de mur wordt gestuurd" maar ook, dat hij zelf genejgd is, om alle mogelijke manieren voor hulp of verlichting aan te wenden. Als at laatste het geval is, dan kan men aannemen, dat de $v j j f$ geneigdheidscomponenten een belangrijke rol spelen bij het valk raadplegen van versoldilende voorzieningen.

Per patiëntencategorie werd de raadplecgfrequentie van patienten met alle in a ammerking komendw personen of instanthes gesommeera. De aldus verkregen score voor liet "veel gebruik van verschillende vooriteningen" 1 "werd gecorreleerd thet warden van geneigdheidscomponenter alsmede met het antwal voorgeschreven controles (als indicatles voor de noodzak voor veel consumptie). In tabel 14.1. zijn de resultaten wergegeven. 
Tabel 14.1. Relltie tussen weel gebruik van verschillende geronoheldszorgwoorzieningen, controlenoodzak en consumptiegeneigaheld per patigmencategorde (rho's, $N=$ driemal 25 )

veel congumptig varis

vertroumen in medische zorg (reel $\rightarrow$ weintig)

atcitude t.a.v. arts (popitief - negatier)

zhekteopvattingen onprof. * profession*)

zirek tebe lieving

(slecht $\rightarrow$ goed)

gedragsintentie

(sterk - gering)

controlenoodzaak

(welnig t vel)

\section{hartinfaret- diabetici} patienten

psoriasispatienten

$\begin{array}{lll}.06 & -.05 & -.37 \\ .05 & -.20 & -.13 \\ .14 & -.35 & -.24 \\ -. .47 & -.29 & .00 \\ -.09 & .10 & .22 \\ . .42 & .50 & .54\end{array}$

$=$ significant $(\mathrm{p}<.05)$

In de eexste plaats is duidelijk, dat de controlenoodzaak in alle arie patientencategorieën een grote - bij diabetici en psoriasispatiënten zelfs de grootste - samenhang met-veel gebruik van verschillende voorzieningen vertoont. De samenhang met de consumptiegeneigdheid is daarbij gering. Dit is warschijnlijk mede te begrijpen tegen de achtergrona van de aard dex hiex bestudeerde gezondheidszorgvoarzieningen. Als een diabeet bijwoorbeeld vaak bij het laboratorium èn vaak bij de diëtiste komt, zal hij vermoedelijk ook veel controles moeten laten ultwoeren. Voor de andere patiëntencategorieän en voorzieningen geldt dit eveneens.

In de tweede plates valt echter op, dat voor hartinfarctpatiërten de meex emotionele ziektebeleving een rol speelt, terw 11 bij de andere twee patiantencategoriean de tot dusver mindex invloedrijk gebleken zorg- en ziekteopvattingen signiflcant met het gebruik van veel vooxieningen correleren. Dit wijst er wellicht op, dat veel hulp zoeken bij verschiliende instanties - afgezien var de vooxgeschreven controles - zowel gevolg kan zijn van psychisch-emotionele als van meex rationele invloeden. 
Kan men lets zeggen over de invloed wan de consumptiegeneigaheid op de veelvaldige consumpte van alle patienten tezamen? Dit is - gezlen de gevarleerdheld van te analyseren voorzieningen - siechts in beperkte mate magelijk. Veelvuldig gebruik kan voor alle respondenten siechts zinvol geoperationaliseerd worden door het antal wuisarts-" eigen specialisten overig specialistenconsulten bij elkaar te tellen.

Deze somscore is als athankelijke variabele in een stapsgewijze regressie-analyse opgenomen met de consumptiegeneigdheidscomponenten (en de controlenoodzalk) als onafhankelijken. Tabe1 14.2. geeft een overzicht van de uitkomsten. zij wijzen erop, dat de consumptiegeneigdheid siechts een geringe (en niet significante) rol speelt bij veelvuldig gebruik van gezondheidszorgvoorzieningen. Alleen de ziektebeleving be-

Tabel 14.2. De mate warin de vije geneigdheidscomponenten veel gebruik wan werschillende gezonaheidszorgvoorzieningen verklaart (stapsgewijze regressle-analyse, gezuiverd voor controlenoodzaak, $\mathrm{N}=75$, 1 )

onafhankelijke wariabelen toegevoegd partide regr.- $F^{n}$ verkl. vrariantile coefteicidnt (B)

\begin{tabular}{|c|c|c|c|c|c|}
\hline controlenoodzaak & 26.6 & .42 & 4.4 & $\mathbb{P}$ & $<.001$ \\
\hline attitude t.a.w. arts & & & & & \\
\hline $\begin{array}{l}\text { posteief r ngatief } \\
\text { ziektehelewing. }\end{array}$ & 2.9 & .16 & 2.09 & & N.S. \\
\hline slecht -goed & 3.5 & -.24 & 4.55 & $\mathrm{P}$ & $<.001$ \\
\hline $\begin{array}{l}\text { wertrouwen in medische } \\
\text { zorg veel }+ \text { weinig }\end{array}$ & 1.2 & .13 & 1.19 & & N.S. \\
\hline gedragsintente & & & & & \\
\hline sterk $\Rightarrow \operatorname{geth}$ & 0.2 & -.04 & 0.15 & & $N_{m} S_{*}$ \\
\hline $\begin{array}{l}\text { opvattingen over id ekte } \\
\text { onprofes. proression. }\end{array}$ & D.. 1 & -.02 & 0.016 & & $N_{w}:$ \\
\hline $\begin{array}{l}\text { totaal } r^{2} \text { door cons. } \\
\text { genelgdheid }\end{array}$ & 7.9 & & $1 * 19$ & & $N . S$. \\
\hline totatal $x^{2}$ & 34.58 & & 6.06 & $p$ & $<.001$ \\
\hline
\end{tabular}

1) zie bijlage 7 vort de marix wan product-moment ooredities. 
reikt en significant niveau, terwijl de overige componenten een verwarloomaar kleire invloed ultoefenen. De controlenoodzak is hierbij verreweg de belangrijkste factor.

Wat kan ex over de invloed van netwerkkentherken worden opgemerkt? (tabel 14.3.)

Tabel 14.3. De mate warin bepalde netwerkenmerken veel gebruk van werschillende gezondheidszorgroorzdeningen wexklaren (stapsgewijze regressie-analyse, gezuiverd voor controlenoodzak, att Lude t.a.v; arts en ziektebleving van de patient, $\mathrm{N}=\mathrm{max} .75$ ) 1 .)

\begin{tabular}{|c|c|c|c|c|}
\hline $\begin{array}{l}\text { onatharkeli jke } \\
\text { vartabelen }\end{array}$ & $\begin{array}{l}\text { \& todgewogde } \\
\text { verkl.variantie }\end{array}$ & $\begin{array}{l}\text { partiale regr.- } \\
\text { coêtfficient (B) }\end{array}$ & $\mathrm{F}$ & sign. \\
\hline $\begin{array}{l}\text { controlenoodzaak } \\
\text { weitidg } \rightarrow \text { veel }\end{array}$ & 26.6 & .31 & 8.72 & $p^{\alpha} .001$ \\
\hline $\begin{array}{l}\text { attitude arts pationt } \\
\text { positief } \rightarrow \text { negatief }\end{array}$ & 3.0 & -.13 & 1.60 & N.S. \\
\hline $\begin{array}{l}\text { ziektebeleving patient } \\
\text { slecht } \rightarrow \text { goed }\end{array}$ & 3.5 & -.03 & 0.05 & N.S. \\
\hline $\begin{array}{l}\text { ziektebeleving le adv. } \\
\text { slecht } \rightarrow \text { goed }\end{array}$ & 9.7 & -.31 & 8.37 & $\mathrm{p}<.001$ \\
\hline $\begin{array}{l}\text { oordeel le du, over ziel } \\
\text { gezond } \rightarrow \text { zidex }\end{array}$ & 3.4 & .22 & 1.08 & N.S. \\
\hline $\begin{array}{l}\text { mate van genelgdheld } \\
\text { sterk } \rightarrow \text { gering }\end{array}$ & 0.9 & -.11 & 4.81 & $p<.001$ \\
\hline$r^{2}$ door netwerkkenmerken & 14.08 & & 3.53 & $P<.001$ \\
\hline
\end{tabular}

1) bijlage 7 bevat de matrix van product-moment correlaties

De invloed van netwerkkemmerken op het radplegen wan veel verstillemde artsen 13 relatief groot. Tabel 14.3. toont aan, dat netwerkleden een belangrijke drijfveer zijn bilj deze worm(en) van -medische consumptie. Waaschijniljk blijkt hierult opnieuw, dat angst en bezorgdheid van meestbetrokkenen iemands patiëntenrolgedrag - hiex in termen van het veel (en oweral) zoeken van genezing - mede bepalen. 


\subsection{Het raadplegen van alternatieve generers}

In de afgelopen jaren is de belangsteling voor nietuniversitaire geneeswijzen sterk toegenomen. Het raadplegen var alternatieve genezers ligt niet langer in de taboesfeer. nu er officiele adviezen op dit gebied zijn uitgebracht (commissie Alternatieve Geneeswijzen, 1981) en verzekeringsmaatschappijen ertoe overgaan, bepaalde niet-universitaire behandelingen in hun verzekeringspakket op te nemen. Uit cassee's onderzoek in 1967 bleek, dat "bij een minaerheid der ondervraagden de mening leeft, dat kruldendokters en magnetiseuxs een gevar woox de matschappij vormen, wartegen de polftie streng behoort op te treden" (Cassee, 1973, p. 112). Uit verschillende onderzoeken is inmiddels gebleken, dat de houding ten aanien van alternatieve genezers positiever is geworden. (Sociaal en Cultureel Planbureau, 1978, Oajjendijk e.a. 1980).

over de omwang van het gebruik wan alternatieve genezers in Nederland zijn slechts schattingen bekend. Men kan aannemen, dat het om 7 a 8 miljoen contacten tussen patienten en genezers per jaar gaat (Van Dijk, 1976, Ooijendijk e.a., 1980). warom raaplegen mensen niet-universitaire genezers? over het algemeen zijn deze consulten te zien als aarvuling op en niet als een alternatief voor "gewone" geneeskundige hulp. Veelal biedt een reguliere behandeling onvoldoende verlichting of bevrediging voor de patiënt, die daarom op een gegeven moment zijn heil elders gaat zoeken. Var Es merkt hierover op: "Naar analogie van de relatie tussen kerk en secten zou men vele niet-officiele geneeswijzen als onbetalde rekeningen van de officiële geneeswijzen kumnen beschouwen" (Van Es, 1976, P. 7). Dit impliceert, dat men niet voor alle klachten bij alternatieve genezers anklopt. Klachten, dLe door de officiele gereeskunde minder makkelijk of helemal niet verholpen kunnen worden komen hiervoor eender in aanmerking. Cassee noent in dit verband psychosen, aandoeningen wan zenuwtelsel, zintuligen en van het bewegingsapparaat, dat wil zeggen vooral klachten van chronische aard (cassee, 1973, p.121).

Men kan dus verwachten, dat er onder de bij ons onderzoek betrokken patienten gezien hum chronische aandoening personen zijn, die contact met alternatleve genezers gehad hebben. Dat 
is inderdad het geval; acht respondenten hebben minsten eeinmal een van hen geradpleega. Dat is - gezien de hiervoor genowme schattingen - niet veel; zeker niet meer, dan voor alle, ook niet chrontsch-zleke Nederlanders wordt vermeld. Maar de aard van de aandoening speelt daarbij naturilijk een rol: van deze acht personen heeft ex ebn een hartinfarct gehad, en twee wan hen zijn diabeet. De overige vijf personen hebben psoriasis. Gezien de kans op genezing via officiele behandeling is deze ultkonst alleszins begrijpelijk. Wan Veen-vietor (1980) wjst expliciet op de mogelijkheden, die alternatieve geneeswijzen voor psoriasispatiënten bieden.

Aan de respondenten is ook gevraagd, of zjj ex wei eens an gedacht hebben, om een of meer van zeven met name genoemde alternatleve genezers voor hun aandoening te raadplegen. onder hen, die hierop positief reageerden, bevinden zich vijf mensen warbij deze overweging niet in een feitelijk consult resulteerde. Wij gaan ervan uit, dat $z i j$ een relatief positieve houding ter aanien van niet-universitaire geneeswijzen hebben. Wij construeerden een schall, die de mate weergeeft, warin men geneigd is, alternatieve genezers te raadplegen.

Speelt de consumptiegenelgdheid een rol bij het raadplegren var alternatieve genezers? Gezien de resultaten wan cassee kan men in leder geval een samenhang tussen "het hebben van orprofesstonele ziekteopvattingen" en onze schaalwaarde verwachten (Cassee, 1973, p. 113). Het is bovendien aannemeldjk, dat mensen, die over een consult aan een niet-officiële genezex denken, of die zo lemand ook echt radplegen, hun eigen arts relatief negatief beoordelen en bovendien niet gauw geneigd zijn, om met lichamelijke klachten de dokter te consulteren (gexinge gedragsintentie). Woorts is het waarschijndijk, dat zij vrij weinig vertrouwen in de medische zorg zul. len hebben." Mensen met een relatief sleohte zlektebeleving tenslotte, zulJen hum hetl eerder bij alternatieve genezers zoeken, dan mensen die hun aandoening tot op zekere hoogte hebben aanvard.

onze verwachtingen komen maar zeer ten dele overeen met de werkelijkheid, zoals die uit ons onderzoek blijkt. (tabel 14.4.)

De consumptiegeneigaheid verklaart rujm 38 variantie in 
Tabel 14.4. De mate waarin vijf geneigoheidscomponenten het (eventuele) raadplegen an altematieve, genezers verklaxen (stapsgewilye regressie-analyse, $N=73$ ) 1 )

\begin{tabular}{|c|c|c|c|c|}
\hline $\begin{array}{l}\text { onafhanke lijke } \\
\text { variabelenk }\end{array}$ & $\begin{array}{l}\text { perc. toegeyoegde } \\
\text { werk1. variantie }\end{array}$ & $\begin{array}{l}\text { pantiele regr. } \\
\text { coeficient }(B)\end{array}$ & F & sign. \\
\hline $\begin{array}{l}\text { vertrowwen med. zorg } \\
\text { (veel } \rightarrow \text { welnig) }\end{array}$ & 8.1 & .37 & 8.79 & $p<.001$ \\
\hline $\begin{array}{l}\text { attitude tma.v. arts } \\
\text { (positief } \rightarrow \text { negatief) }\end{array}$ & 6.0 & -.31 & 6.23 & $p<.001$ \\
\hline $\begin{array}{l}\text { zirk tebeleving } \\
\text { (siecht } \rightarrow \text { goed) }\end{array}$ & 4.2 & -.21 & 3.46 & $p<.01$ \\
\hline $\begin{array}{l}\text { gedragsintentie } \\
\text { (sterk } \rightarrow \text { gering) }\end{array}$ & - & .03 & 0.07 & N.S. \\
\hline $\begin{array}{l}\text { ziekteopuattingen } \\
\text { (onprof. } \rightarrow \text { profession.) }\end{array}$ & - & -.02 & 0.04 & N.S. \\
\hline totaal $x^{2}$ & 18.38 & & 3.09 & $p<.01$ \\
\hline
\end{tabular}

1) van twee respondenten is niet bekend, of zif (eventueel) alternatieve genezexs raadplegen; zie bijilage 7 voor de matrix van product-moment correlaties.

het (eventueel) raadplegen van alternatieve genezers. Dat 1 s een bevredigend resultaat, dat in $z$ "n geheel de gedragsvoorspelLende warde van de hier onderscheiden consumptiegeneigaheidscomponenten ook in verband met het gebruik van alternatieve gezondheids zorgroorzieningen onderstreept.

Bekijkt men de invlaed van de afzonderlijke componenten. dan vinden wij twee uitkomsten, die zeer wel begrijpelijk zijn, mar ook twee ultkomsten, die met hetgeen wij verwachten volstrekt in tegenspraak $z i j n$. On met het eerste te beginnen: de belangrijkste determinant van het (eventueel) raadplegen van alternatieve genezers is een gering vertrouwen in de traditionele medische zorg. Bovendien komt het (overwogem) bezoek aan deze genezers voort uit een relatief slechte zlektebeleving. Dit is alleszins plausibel en behoeft geen verdex commentar. In de tweede plats blijken (on) professionele ziekteopvattingen tegen onze verwachting in in deze geen invlaed uit te oefenen en - wat bijna verbazingwekkend is - blijkt niet een negatieve doch een uitgesproken positieve attitude ten aanzien van de igen arts wan invloed te zijn op het (voorgenomer) bezoek an alternatieve genezers.

De ontbrekende invloed van de ziekteopvattingen bleek reeds 
ecrder (zle hoofdstuk 7 ). Wij schreven deze vornamelijk toe an wermodelijk veranderde opwatingen over ziekte bij het mederiandse publiek vergeleken met rulm tien jaar geleden, toen cassee zijn ondexzoek deed alsmede ar een andere steekproefsamenstelling dan dle van cassee. Waarom hebben personen, ale (eventueel alternatieve genezers raaplegen echter $20^{\circ} \mathrm{m}$ positieve attitude ten aanzien van hun arts? Dat men zijn heil elders zoekt, womt duldelijk niet woort uit ontevredenheid met de behamdelend arts..

De ultkonst kan vermodelijk als volgt worden geinterpreteexd. Personen, die overwegen, on alternatieve genezers op te zoken of ale dat inderdaad doen, zijn warschijnlijk zelf tot de conclusie gekomen, dat de traditionele medische zorg op bepaalde punten niet in hun behoefte kan voorzien. Hun geringe vertrouwen in de medische zorg wijst daar op. zij verwijten echter hun elgen axts op dit punt niets integendeel: "... hij is steeds geneigd alles te proberen, wat eraan te doen is ..." " "... hij is eerlijk, maar meer kan hij ook nlet voor me doen..." "...hlj probeert je altijd op je gemak te stellen en heeft alle begrlp voor me..." aldus enkele reacties van respondenten.

Dit sluit aar bij de constateringen van van es (In: Van Dijk, 1976, p. 7). Hij zegt, dat ..."de arts ... meer dan vroegex ervan op de hoogte wordt gesteld als patienten hulp bif een ander gaan zoeken" en dat "in een dergelijke situatie de huisarts ook wel eens on advies wordt gewraagd." Dit zou warschijnlijk niet gebeuren, als men over zijn arts ontevreden was. Dverigens blijkt ex geen samenhang tussen het (mogelijk) raadplegen wan aiternatieve genezers en het aantal huisartsconsulten (rho $=.05, \mathrm{~N} . \mathrm{S}$. ). ${ }^{3}$ )

wij onderzochten ook, of mensen, die hun heil (ook) buiten de offlojale kanalen zoeken in opleiding en leeftijd van anderen verschillen. Daarblj bleek, dat $z j j$ wel jonger (rho= $-.22, p<.03)$ mar niet duidelijk hoger of minder hoog opgeLeid zijn (rho $=.18$. N.S.) dan personen, die noolt aan een "alternatue consult" gedacht hebben. Dit is ammemelijk, aangezien psoriasiupatienten in onze steakprof relatief jong zijn en zij de meeste consulten met niet officiële genezers voor hun rekening bemen. 
Spelen bepaalde netwerkenmerken nog ean rol bij het raadplegen van alternatieve genezers? Het lijkt zinol, on voor het antwoord op deze vraag ook het vertrowwen, dat de lekenadviseur in de medische zorg stelt, in de beschouwing te betrekken. (tabe1 14.5.)

Tabel 14.5. Mate warin bepalde netwexkenmerken het radplegen van aternatieve genezers yerkiaren (stapsgew joe regressieanalyse, $\mathrm{N}=\max .73$ ) 1 )

\begin{tabular}{|c|c|c|c|c|}
\hline $\begin{array}{l}\text { onafharkedijke } \\
\text { variabelen }\end{array}$ & $\begin{array}{l}\text { perc. toegevoegde } \\
\text { verki. variantile }\end{array}$ & $\begin{array}{l}\text { particle regr.- } \\
\text { coefficient (B) }\end{array}$ & F & sign. \\
\hline $\begin{array}{l}\text { ziektebeleving patient } \\
\text { slecht } \rightarrow \text { goed }\end{array}$ & 5.2 & -.26 & 3.70 & $p<.01$ \\
\hline $\begin{array}{l}\text { vertrouwen med. zorg } \\
\text { patient veel } \rightarrow \text { weinig }\end{array}$ & 5.5 & .16 & 1.43 & N.S. \\
\hline vertrouwen med, zorg & & & & \\
\hline le adv. veel - weinig & 4.2 & .27 & 4.12 & $\mathrm{p}<.001$ \\
\hline $\begin{array}{l}\text { aordeel le adv. ov, zhekte } \\
\text { gezond } \rightarrow \text { ziek }\end{array}$ & 2.6 & -.14 & 1.12 & N.S. \\
\hline $\begin{array}{l}\text { mate van genejgdheid } \\
\text { sterk } \rightarrow \text { gering }\end{array}$ & 0.8 & -.13 & 0.85 & N.S. \\
\hline $\begin{array}{l}\text { ziektebeleving } 1 \text { e adv. } \\
\text { slecht } \rightarrow \text { goed }\end{array}$ & 0.8 & .11 & 0.67 & N.S. \\
\hline$x^{2}$ door netwerkkenmerken & 8.39 & & 1.47 & $\mathrm{~N}_{2} \mathrm{~S}$ \\
\hline
\end{tabular}

1) bijlage 7 bevate de matrix van product-moment correlaties: zle ook noot bij tabel 14.4.

De invloed val lekenadviseurs op het radplegen van alternatieve genezers is gexing, maar het vextrouwen van de meestbetrokkene in de medische zorg is daarop wel (significant) van invloed. Ook hier blljkt weer, dat netwerkkenmerken op het zlektegedrag van de patient van invioed $21 j n$, nastit de rol die zijin eigen consumptiegeneigalueld darbij speedt.

14.3. Consumptiegenelgdheid en verzekeringsvorm

14.3.1. Inleiding

Narmate het vraagstuk van de Ellnancieringswijzen van gezondheidszorgwaorzieningen meer aandacht krijgt, heemt ook de 
belangsteling roor de invloed van de verzekeringsworm op medische consumptie toe. In 1980 is ower dit onderwerp een onderzoekersoverleg gestart (Ministerie van $V$. en $M$, 1980). Uit een door viex leden wan deze groep samengesteld overzicht van relevante stules op at gebied blijkt onder meer, dat alekenfondsverzekerden meex gebraik maken van geneeskundige hulp. Daarbij is vooral het verschil in gebruik van ziekenhulsbedden opvallend. De groep van onderzoekers heeft zich ook gebogen over de eventuele ooraken van deze verschillen. Wij willen hierop in dit kader niet uitgebrela ingaan en verwijzen ervoor naar van de ven e.a. (1981).

over de rol, die de consumptiegeneigdheld hierbij speelt is tot dusver welnig onderzoek gedaan. zijn fondspatiënten eerder geneigd medische hulp in te roepen dan met hen op andere punten vergelijkbare particulier verzekerden? Deze studie biedt de mogelijkheid om hierin meer inzicht te krijgen. 53 Respondenten zijn lid van het ziekenfonds, twee particulierverzekerden zijn tegen alle kosten van de huisarts verzekerd, terwijl negen van hen hiervoor een bepaald elgen risico aragen. De overige elf particuliex verzekerden moeten de kosten voor de huisarts zelf betalen. In het volgende vergelijken wij de eerste twee groepen (55) met de overigen.

De ondervragade personen hebben allen een chronische aandoening en zijn daraoor - uiteraard globaal en mar tot op zekere hoogte - vergelijkbaar op het punt wan hun gezondheidstoestand. Wij gaan daarop nog nader in. onder hen bevinden $z$ ich bovendien weinig zeer oude mensen, die het beeld kunnen verstoren, doordat zij fondsild zijn en bovendien voor allerleil oudexdomskwalen de dokter consulteren.

\subsubsection{Enkele verschillen tussen fondsieden en particulier verzekerden nader onderzocht}

Alvorens de relatie tussen verzekeringsvorm en consumptiegeneigdheid aan de orde te stellen, willen wijeerst wat preclezer nagan, op welke purten de fondsleden wel en op welke punten $z j j$ hiet met particulier verzekerden vergelijkbaar $z i j n$. Daarbij is het in eerste instantie van belarg, in welke mate hun gezondhejdstoestand overeenkomt. De verdeling over patien- 
tencategorieen wijst niet op duidelijke verschillen laje bijLage 1), mar er ijn wel aanwijzingen voor het feit; dat fondspatienten "ernstiger" ziek zijn dan particulier verzekerden. (tabe 14.6.$)$

Tabe 14.6. Verschilien tussen fonospatienten en particuliex verekerden in "gezondheidstoestand" i) (Mann-Whitrey-toets, eenzijaig)

\begin{tabular}{|c|c|c|c|c|}
\hline & $\begin{array}{c}\text { fonds- } \\
\text { patienten } \\
(\mathbb{N}=55)\end{array}$ & $\begin{array}{l}\text { Particuliere } \\
\text { patidenten } \\
(N=20)\end{array}$ & $\mathbf{z}$ & $\operatorname{sign}$. \\
\hline owerige aandoeningen & 40.75 & 30.42 & 1.97 & $p<.02$ \\
\hline $\begin{array}{l}\text { ernst aanaoening vl } \\
\text { ggave van de arts }\end{array}$ & 29.42 & 21.88 & 1.86 & $p<.03$ \\
\hline
\end{tabular}

1) Fondspatienten incl, volledig voor hulsartsenhulp verzekerden

Dit is op zichzelf verrassend, omdat wij niet verwachtten, dit door anderen geconstateerde verschil (Kuyvenhoven en Touwotten, 1978, Mootz, 1980) nog binnen een betrekkelijk kleine, homogene groep van chronische patiënten aan te treffen. Bij de interpretatie van bet volgende moet hiermee rekening worden gehouden.

Mede door de onderzoeksopzet spelen persoonskenmerken darin een betrekkelijk ondergeschikte rol, zo bleek in het voorgaande. Volledigheidshalve hebben wij het verband tussen geslacht, leeftija, opleiding en urbanisatiegraad van de woongemeente en verzekeringsvorm onderzocht alvorens op de consumptiegeneigdheid verder in te gaan. Het bleek, dat fondsleden vergeleken met de overige respondenten alleen lager zijn opgeleld (hetgeen te werwachten was) matr op de andere punten verschillen de twee groepen niet van elkaar. Wij zulien onze analyses daarom voor opleldingsriveau controleren.

Tenslotte vragen wij ons af, of zich onder de particulider verzekerden meer specialist-patiënten bevinden, dan onder de fandsleden. De bevindingen uit ander onderzoek lvan de ven, e. a. $1981 /$ zouden dit a annemelijk maken. Dit is echter in dit onderzoek niet het geval: 23 huisartspatienten zijn fonds $\mathbb{1}$ id, tegenover 29 particulier verzekerden $\left(x^{2}=.99\right.$ N.s.). Met name de attitude ten aanzien van de eigen arts wordt hierdoor dus 
niet verstoord (zie hoofdstuk 13, tabel 13.4.). Volledig verzekerden blikken bovendien hun huisarts noch hun specialist vaker te radplegen dan niet volledig verzekerden voor het aantal huisartsconsulten geldt $0.9 . \%$. de Mann Whitney-toets: $z=0.95$. voor het antal specialistconsulten: $z=0.45$; beide warden zijn nite significant).

14.3.3. De consumptiegeneigdheid en de verzekeringsvorm

Waarom maken fondspatiënten meex gebruik van bepaalde gezondheidszorgvoorzieningen dan anderen? Eer deel van het verschil komt uiteraard voor rekening van de vermelde morbiditeitsverachlien, een ander deel is toe te schrijven an algemene kenmerken van mensen uit lagere sociaal-economische milieus. vooral voor meer specialistische voorzieningen geldt bovendien dat kenmerken van het gezondheidszorgsysteem zelf een belangrijke rol spelen. Maar voor gevallen, waarin de beslissing tot medische consumptie binnen het lekensysteem ward genomen dat w1 zeggen bij veel huisartsconsulten - werd geen goede reden voor het verschil gevonden (Van de ven e.a., 1981).

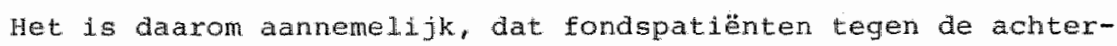
grond van hun volledige verzekering een relatief sterke consumptiegeneigdheid hebben; een factor, die tot nog toe relatief weinig aandacht heeft gekregen.

wij hebben op drie manieren geprobeerd, dit vraagstuk te onderzoeken. In de eerste plaats vergeleken wij de 55 volledig verzekerden met de overige respondenten op hun afzonderlijke geneigdheidscomponenten. (tabed 14.7.)

Van de uitslagen is er slechts een significant: volledig verzekerden houden er minder profesionele gezondhedasopvattingen op na dan particulier veraekerden. Dit is tegen de achtergrond van hun lagere opleiding exg plausibel. Var de andere ulublagen wijeen er twe in de rlohting van een sterkere consumptiegenelgdheid van fonds-vergeleken met particulier verzekerden. De eerste groep heeft en lets sterkere gedragsintentie dan de tweede en bovendien wat meer vertrouwen in de medische zorg. De andere twee componenten wijzen in de tegengestelde richting: fondsleden denken iets negatiever over hum eigen arts en hebben een lets betere ziektebeleving dan de anderen. 
Tabel 14.7. Verschillen tussen fondsleden en particulier verzekerden in him consumptiegeneigdheid (Marn-Whitney-toets, tweezijalg)

$\begin{array}{cc}\text { fords. particulier } & \text { sign. } \\ \text { patienten } & \text { patienten }\end{array}$

vertrowwen 1. med zorg

(vere1 * weinig)

37.06

40.57

0.62

$\mathbb{N} . S$.

attitude t.a.v. arts

(positief + negatief) 38.60

34.52

0.72

W. 5 .

opvatting over ziekte

tonprof. $\rightarrow$ profess.)

34.16

48.55

2.53

$\mathrm{P} \& .01$

ziektebeleving

(slecht $\rightarrow$ goed)

38.23

37.38

0.15

N. S .

gedragsintentie (sterk $\rightarrow$ gening)

N.S.

Al met al bxengt ons dit miet tot een duidelijke conclusie. Wij kunnen hooguit zeggen, aat - zo er al verschillen in consumptiegeneigaheid gevonden worden - deze op het cognitleve vlak liggen, hetgeen gezien verschilien in opleiding to verwachten was. Op het wlik van de - voor de medische consumptie belangrijker - attituden ter aanzien van eigen arts en elgen aandoening zijn de verschilien tussen de twee groepen ce gering om er en conclusie op te baseren.

In de tweede plats berekenden wij de correlaties tusisen verzekeringsvorm, consumptiegeneigaheid en feitelijke medische consumptie. Tabel 14.8. lat de resultaten zien en vermeldt deze afzonderlijk bij controle voor opleiaingsniveau.

Deze tabel laat zien dat de samenlang tussen verzekeringisvom en consumptiegeneigdheid gering is. De enige corielatie met een beviedigend significantieniweau is die tusgen (on)professlonele ziekteopvattingen en verzekeringsvorm. Deze neemt door de invioea van het opleidingsniveau te elimineren af. Voorts blijkt, dat de samenhang tussen verzekeringsvorm en medische consumptie niet significant is.

In de derae plats gingen wij na, welke rol de consumptidegeneigaheld van volledig verzekerden speelt, als zij hum hug arts raadplegen. Wij berekenden voor beide groepen a zonderlijk correlaties tussen de viff genelgdheidscomponenten en het an- 
Tabel 14.8. Sameninang tussen verzekeringsworm, consumptiegenelgdheid en medische consumptie (Kendall's rangcorrelaties, eerste regel: (A) nulde-orde, tweede reqel: (B) gecontroleex voor gpleldingsniveau, $N=75$, omkaderd: significant, $p<.05$ )

(1)

(4)

(5)

(6)

\begin{tabular}{lccccccc}
\hline A & .07 & -.08 & 0.23 & .06 & .10 & -.13 & -.03 \\
B & -.01 & -.09 & .17 & .07 & .06 & -.13 & -.08 \\
\hline
\end{tabular}

i) verzekeringsworm fonds $\rightarrow$ particulier

$B$ idem, gecontreerd vor opleidingsniveau

(1) vertrorswen in nedische zorg (veel - weinig)

(2) attitude t.a.v. eigen arts (positief $\rightarrow$ negatief)

(3) ziekteopvattingen (onprofessioneel $\rightarrow$ professioneel)

(4) ziektebelewing (silecht $\rightarrow$ goed)

(5) gearagsulutentie (sterk $\rightarrow$ gering)

(6) radaplegen huisiarts (welnig - vaak)

(7) raadplegen speclalist (weinig $\rightarrow$ vaak)

pabel 14.9. Samentungen tussen consumptiegenelgaheid en het aantal hulsartscontacten. apart voor volledig verzekerden en particuliere patienten $(N=55$ en $N=20$, Kendall"s rangeorrelaties)

(1)

(2)

(3)

(4)

(5)

(A) raadp1. huisarts nulie-orde, fondsleden

$\begin{array}{lllll}-.19 & -.24 & -17 \quad-.20 & -.11\end{array}$

idem, particulier verizekerden

$\begin{array}{lllll}-.18 & -.11 & .04 & -.29 & .03\end{array}$

(B) idem, gecontroleerd voor opleiding, fondsleden

$$
\begin{array}{ccccc}
-.18 & -. .24 & .18 & -.20 & -.10 \\
-.23 \quad-.10 & -.05 & -.28 & -.01 \\
\square] & =\text { significamt, } p<.05 &
\end{array}
$$

idem, particuliex verzekerden

(1) vertrowwen in medisthe zorg (veel $\rightarrow$ weinig)

(2) atcitude t.a.v. arts (positief $\rightarrow$ negatief)

(3) opvateingen over zlekte conprofessioneel - professioneel)

(4) ziektebeleving (slecht qoea)

(5) gedragsintentice (sterk $\rightarrow$ gering)

tal malen, warmee men de huisarts radpleegt. (tabel 14.9.) Daarbit elimineerden wil weer de invloed var het opleidingsniveau var de patient. 
Deze tabel bevat een (uiterst rwakke) aanwijzing voor het feit, dat de samenhangen tussen medische consumptie en verzekeringsvorm op drie punten sterker zijn bij fondspatiënten dän bij particulier-verzekerden en op twee punten minder sterk. Deze laatste twee $z i j n$ : de ziektebeleving en het vertrouwen dat men in de medische zorg stelt. Vooral het feit, dat de ziektebeleving bij particulier-verzekerden een sterkere invloed heeft op hun huisartsbezoeken dan die van leden van het ziekenfonds, geeft aanlelding tot de volgende, de drie analyses samenvattende, conclusie.

Fondsleden onderscheiden zich niet van particulier-verzekerden in hun geneigaheid, de hulp van de hujsarts in te roepen. Wel bleek dat fondsleden - voorzover hier na te gaan een wat slechtere gezondheid bezitten dan particulier-verzekerden. Dit sluit aan bij de bevindingen van anderen, waaruit blijkt, dat verschillen in medische consumptie wartoe de patient zelf besluit, tussen naar verzekeringsworm onderscheiden categorieën afnemen of verdwijnen, naarmate woor gezondheldstoestand wordt gecontroleerd Mootz, 1978, Van de Ven, e.a." 19811 .

NOMEEA BIJ HOOFDSTHUK 14

1) Zie bijlage 15 voor de enquêtevragen per patiëntencategorie en voox. de samenstelling van de in dit hoofdstuk gebrukte varlabelen en hun st thatitische kentuterken.

2) Bif de uitspraken die tezamen de geneigaheldscomponent "vertrouwen in de medische zorg" vormen, is niet expliciet wan officlale geneeskunde sprake, maar men mag aamemen, dat begrtppen als "artsen" en "de doktex" daarmee geassocieerd worden.

3) Cassee (1973) vond 1 in 1967 een posttieve samenhang: $r$. 23 (pag. 120) 
Hoofdstuk 15. Samenvatting

In hoofdstuk 7 bleken de door ons geoperationaliseerde componenten van consumptiegeneigaheid een grote voorspellendw warde te bezitten voor medische consumptie in termen van het aantal huisartsconsulten. Dit was anleiding, om de ralatle tussen consumptiegeneigdheid en medische consumptie meer in detail aan de orde te stellen. De twee voorgande hoofdstukken doen daarvan verslag. De resultaten hebben geen betrekking op vooraf (in hoofdstuk 3) geformuleerde onderzoekshypothesen. Wij zullen de afzonderlijke witkonsten hier in het kort herhalen.

Hoofdstuk 13 behandelde verschillen tussen hulsarts- en specialistpatienten. Wij vonden een zwakke anwijzing voor het feit, dat specialistpatiënten wat hoger opgeleld zijn dan huisartspatiënten. Verder bleken er geen verschillen: noch de overige persoonskenmerken, noch bepalide ziektekenmerken van specialistpatiëten onderscheiden zich van die van huisartspatiënten. Dat is opmerkelijk, omdat men zou kunnen verwachten, dat patienten die voor hun chronische aandoening bij een specialist in behandeling zijn, hetzij ernstiger hetzij nog pas kort ziek zijn. Dat was hier echter niet het geval.

De twee groepen verschilden wel in de attitude, die zij er ten aanzien van hun arts op nahouden: specialist-patienten zijn op dit punt ontevredener dan huisartspatienten. Die ontevredenheid geldt in het bijzonder de geringe mate warin de specialist informatie verstrekt over onder meer de ernst en de behandeling van de aadoening. zij gelat echter ook in het a1gemeen, dat wil zeggen dat specialistpatienten met het optreden van de specialist over de hele linie wa minder tevreden zijn dan huisartspatientem.

vervolgens onderzochten wij de betekenls van de consumptiegeneigdreid en wan de netwerkenmerken bij medische consumptie afzonderlijk voor huisarts-en specialistpatiknten. Wij vonden daarbij nogal duldelijke verschillen we consumptiegenelgaheld speelt een bijzonder grote rol biy het raadplegen Wan de huisarts $\left(x^{2}=48\right.$ \%). Zij speert een geringere rol bij bezoeken an de huisarts van specialistpatienten $\left(r^{2}=14\right.$ ) en zij speelt praktisch geen rol meer bij specialistconsulten 
van specialistpatienten $\left(r^{2}=7,8\right.$ \% 1 Mij de specialistpiatienten had ook de ziektebeleving van de eerste lekenadviseur een adationele (signiflcante) invloed ap de onderzachte vomen van medische consumptie. Naast de controlenoodzaak, de ziektebeleving en de attitude van de patient ten aanzien van zijn arts, voegen de netwerkkenmerken samen 14 s verklaarde variantie toe arn het aantal specialistconsulten wan specialistpatienten, 15,4 aan het aantal hulsartsconsulten van deze patiênten en tenslotte 16,4 aan de frequentie waamee hulsartspatienten hun huisarts bezoken.

Deze bevindingen geven aanleiding tot de veronderstelling, dat de mate waarin consumptiegeneigdheid en lekenadviseurs de medische consumptie beinvloeden, mede afhangt van een door de patiënt en zijn meest-betrokken adviseurs gepercipleerde sociale arstand ten opzichte van de behandelend arts. Wordt die afstand groter - het door specialistpatiënten ervaren tekort aan informatiej optreden van hun arts wijst daarop - dan neent de invloed van consumptiegeneigdheid en van de lekenadviseurs af. De rol van de afzonderlijke geneigdheidscomponenten en van de netwerkkemmerken is daarblj niet significant en overigens moeilijk te begrijpen. Wordt de ervaren sociale afstand geringer, dan krijgt de consumptiegeneigdheld in toenemende mate betekenis. Deze gelat dan vooral de evaluatieve componenten wan de geneigdheid, namelijk de wijze warop de patiënt zijn ziekte beleeft en $z i j n$ attitude ten aanzien wan zijn eigen arts. Daarbij heeft de ziektebeleving van de eerste lekenadviseur een additionele invloed.

Hoofdstuk 14 gaf wat meer inzicht in de ral, die de consumptiegeneigdheid en de netwerkkenmerken bij andere vormen wan medische consumptie spelen. Wij zagen, dat contact met veel verschillende gezondheidszorgvoorzienirgen voornamelijk moet worden toegeschreven an voorgeschreven controles en aan de invloed van de meest-betrokken lekenadviseurs (toegevoegd percentage verklaarde variantie: $r^{2}=14$ c). De consumptiegenelgdheld van de patient bleek hier van ondergeschikt belang te zijn $\left(\mathrm{r}^{2}=7.9 \mathrm{z}\right)$. Alleen zijn slechte ziektebeleving was wan invloed op het raadplegen van veel verschillende vormen van zorg. In de tweede plaats besteedden wig in dit hoofdstuk aandacht aan het raadplegen van altematieve genezers. Acht 
patiènt-respondenten hadden én of meer allexntieve vormen wan hulp beproefa en nog eens vijf hadden overwogen om dat te doen. De consumptiegeneigdheid was hierop duidelijk van invloed $\left(r^{2}=18,3 \%\right)$. Men kon concluderen, dat het (eventueel) raadplegen van alternatieve genezers vooral voortkomt uit een gering vertrouwen in de (traditionele) medische zorg, uit een slechte ziektebeleving en - geheel tegen de verwachting in uit een uitgesproken positieve attitude ten anzien van de eigen arts. Deze laatste opmerkelijke uitkomst moet vernoedelijk begrepen worden uit het besef van de (vooral psoriasis-) patiënten, dat traditionele behandelingen - door de eigen axts geduldig en veelvuldig beproefd - voor hun kwal geen soelaas kunnen bieden. De eigen arts treft op dit punt geen verwijt. De netwerkkenmerken spelen bij deze vorm van medische consumptie een ondergeschikte rol, warbij wel het vertrouwen dat de meest-betrokkene in de medische zorg heeft, var belang is:

Tenslotte vroegen wij ons af, of leden van het zilekenfonds sterker geneigd zijn, om medische voorzieningen te gebruiken, dan particulier-verzekerden. Deze vraag ligt in het verlengde van de bevindingen van anderen waruit blijkt, dat fondspatienten over het algemeen meer medische consumptie vertonen dan anderen. Dit verschil moet voor een belangrijk deel worden taegeschreven aan - zoals ook in dit onderzoek onder chronische patiënten weer bleek - verschillen in gezondheidstoestand tussen deze twee groepen. Het is echter niet uitgesloten, dat ook hun consumptiegeneigdheid daarbij een rol speelt.

Wij konden voor dit laatste echter op grond van ons materiaal geen steun vinden: fondspatiënten zijn niet meer tot consumptie geneigd dan anderen, en bij feitelijke medische consumptie speelt hun genelgaheid geen grotere rol dan die van particuliex-verzekerden. Eexder in dit deel (hoofdstuk 13 , paragrad 13.5 .3$.$) vonden wij, dat in vexband met medsche$ comsumptie over het algemeen belangrijk te achten persoonskenmexken, zoals iemands opleiding, leeftijd en geslacht, in dit onderzoek een onbeduidende invloed hebben op het antal huisarts- en specialistcontacten. Nu blijkt, dat ook de verzekeringsvorm noch in verband met geneigdheid noch in verband met feitelijke consumptie van belang is, kan de volgende veronder- 
steling worden geformuleerd. In een onderzoek onder chronische putienten, watin dus de consumptienoodzaak grotendeels gelijk is geschakeld, spelen structurele kenmerken en verschijnsellen, die lets over de consumptienogelijkheid zeggen (waronder de verzekering vorm, zie hoofastuk i) als determinanten van medische consumptie een ondergeschikte rol.

Samenvatterid bleek uit dit deel, dat de consumptiegeneigdheld en de netwerkkenmerken ook bij andere wormen wan medische consumptie dan het aantal huisartsconsulten een belangrijke rol spelen. Daarbij konden de bevindingen uit hoofdstuk 7 op bepalde punten worden genuanceerd. De invloed van de consumptlegeneigaheid en de netwerkkenmerken neemt toe, narmate de door de patlënt en zijn lekenadviseurs gepercipieerde sociale afstand tot de behandelend arts afneemt. voorts komt over het algemeen de wijze warop men zijn aandoening en de wijze warop deze door de eerste lekenadviseur wordt beleefd, als belangrijkste geneigdheldscomponenten bij de verschillende vormen van medische consumptie naar voren. Wij veronderstelden, dat warschijnlijk emotionele invloeden zoals angst en bezorgaheid als drijfveer tot het zoeken van hulp hieraan debet zijn. Deze veronderstelling werd gesteund door onze bevindingen ten aanzien van het radplegen van veel verschillende vormen van medische zorg. Daar bleek de angst en bezorgaheid van de meestbetrokkene deze vorm van medische consumptie in sterke mate te bepalen. Voorts word deze veronderstelling gesteund door onze bevindingen ten aanzien van het raadplegen van alternatieve genezers. zoals uit onderzoek van anderen biljkt, is dit te zien als aanvulling op en niet als alternatief voor de "gewone" behandeling. Aan de beslissing on eer alternatieve genezer op te zoeken gat daarom warschijnijk een vrij rationele overweging vooraf. Het raadplegen van alternatieve genezers biljkt in ons onderzoek dan ook mede beinvloed te worden door cogn $\mathbf{L}-$ tieve componenten van consumptiegeneigdheid, namelik een gering vertrouwen van patiënt en lekenaduiseur in de traditionele medische zorg.

NOOT BIJ HOOFOSTUK 15

1) neze percentages verklaarde variantie gelden wanneer de invloed van de controlenoodzak is geelimineerd. 
DEE $\mathrm{E}$

$S Y N O P S I S$ 


\section{Hoofdstuk 16. Overzicht}

\subsection{Intelaing}

Tot dusver werden vele, soms nogal uiteenlopende zaken behandeld. Dit hoofdstuk heeft tot doel, de voornaamste resultaten uit het voorgaande opnieuw te bezien en daamee een samenvattend overzicht te presenteren. Wij gaan daarbij als volgt te werk.

Achtereenvolgens komen die verschijnselen aan de orde, die hiervobr als belangrijkste determinanten van medische consumptie werdem aangemerkt. Per determinant delen wij de respondenten telkens in twee groepen. Wij onderscheiden mensen, warbij thet verschijnsel relatief veel voorkont en mensen, waarbij het relatief weinig optreedt. Als criterium voor die tweedeling gebruiken wij (in de meeste gevalien) de mediaan. Van de patiënt-respondenten in deze graepen bekijken wij dan - als indicator voor hun medische consumptie - de frequentie warmee zij in drie maanden de huisarts consulteerden. Het zal dan moeten blijken, dat de groep, waarbij het de consumptie belnvioedende verschljnsel veel optreed, meex bezoeken aan de hulsarts heeft gebracht dan de andere groep.

De volgorde waarmee wij een en ander beschrijven loopt parallel aan de conclusies, die uit de afzonderlijke delen van de studie konden worden getrokken. Het hoofdstuk eindigt met een dit samenvattende analyse.

\subsection{De consumptiegeneigdheid van de patiënt (deel II)}

Wan de hiex onderscheiden opvattingen, attituden en gedragsintenties, die met medsche consumptie te maken hebben, bleken vooral ae volgende drie componenten de medische consumptie sterk te belnvioeden.

1. attitude t.a.v. de elgen ziekte, ook wel ziektebeleving genoemd:

2. attitude t.a.v. de elgen arts;

3. neiging om met bepalde klachten de dokter te radalegen, ook wel gedragsintentie genoemd. 
Met behulp van de median van deze variabelen werden de respondenter in criemal twee ongeveer even grote groepen gesplitst. Wij bekeken die groepen in hun onderlinge samenhang. door op grond van zlektebeleving, de attitude ten aanzien van de arts en de gedragsintentie acht categorieen te onderscheiden. Voor hen berekenden wij de gemiddelde raadpleegfrequencles "Tabel 16.1. Lat de resultaten zien.

Tabel 16.1. Gemldde 1d aantal hulsartsconsulten nat drie componenten van consumptiegenelgaheid

\begin{tabular}{|c|c|c|c|c|c|}
\hline \multicolumn{2}{|c|}{ zuektebeleving } & attitude arts & gearagmintentie & $\begin{array}{l}\text { raadpleeg- } \\
\text { rrequentie }\end{array}$ & W \\
\hline (1) & slecht & positief & sterk & 2.37 & 8 \\
\hline$(2)$ & slecht & positief & gering & 2.25 & 4 \\
\hline (3) & slecht & negatief & sterk & 0.70 & 10 \\
\hline (4) & sulecht & negatief & gering & 0.86 & 14 \\
\hline (5) & goed & positief & sterk & 1.30 & 10 \\
\hline$(6)$ & goed & positiex & gering & 0.60 & 15 \\
\hline (7) & goed & negatief & sterk & 0.11 & 9 \\
\hline (B) & goed & negatief & gering & 0.00 & 4 \\
\hline
\end{tabular}

Deze cijfers illustreren opnieuw, dat de drie geneigdheidscomponenten tezamen een duidelijke invloed op de raadpleegErequentle uitoefenen. De volgorde van de acht groepen op grond van het aantal consulten komt in grote lijnen overeen met hetgeen men nat anleiding van onze eerdere bevindingen kon verwachten. De enige uitzondering vornt groep (3) "dle tegen de werwachting in minder huisartsbezoeken bracht dan groep (4). voorts vall op, dat een positieve attitude ten aanzien van de arts in combinatie met een sterke gearagsintentie in een groep met een relatief goede ziektebeleving (5) met meer consulten gepara gat, dan de relatief slechte zlektebeleving van de groepen (3) en (4). De patiënten uit deze latste twee groepen worden blijkbar door hun negatieve attitude ten aanjen van hun arts van veel bezoeken aan hem weerhouden; ait ondanks hun relatief slechte ziektebeleving. 
Volledigheidshalve zulien wij - evenals in het voorgamde - aandacht besteden aan eventueel voorgeschreven (controle-) consulten. Daarvoor splitsen wij de respondenten opnieuw in twee groepen: een groep, warvoor twee of minder jaarlujkse consulten zijn voorgeschreven $(N=36)$ en es groep respondenten, die drie of meer mal per jaar woor comtrole naar de dokter moten $(N=39)$. Voor deze twee groepen is de invloed van genoemde geneigdheidscomponenten op de radpleegfrequentie afzonder $1 \mathrm{j} j \mathrm{k}$ ragegaan (tabel 16.2. ).

Tabe1 16.2. GemiddeId aantal huisartsconsulten natar drie componenten van consumptiegeneigcheid, apart voor respondenten met veel. resp. weinig of geen voorgeschreven consulten

\begin{tabular}{|c|c|c|c|}
\hline controles & geneigdheid & $\begin{array}{l}\text { gen. xaadpleeg- } \\
\text { Exequentie }\end{array}$ & $\mathbb{N}$ \\
\hline & ziektebeleving & & \\
\hline veed. & slecht & 1.35 & 26 \\
\hline veel 1 & goed & 1.15 & 13 \\
\hline weinig & slecht & 1.09 & 11 \\
\hline \multirow[t]{2}{*}{ weining } & goed & 0.32 & 25 \\
\hline & attitude arts & & \\
\hline veel & positief & 1.94 & 18 \\
\hline veell & regatief & 0.71 & 21 \\
\hline weinig & positief & 0.79 & 19 \\
\hline \multirow[t]{2}{*}{ weinig } & negatief & 0.31 & 16 \\
\hline & gedragsintentie & & \\
\hline veel & sterk & 1.37 & 19 \\
\hline veel & gerirg & 1.20 & 20 \\
\hline weinig & sterk & 0.74 & 19 \\
\hline meinig & gextng & 0.35 & 17 \\
\hline
\end{tabular}

over het algemeen raadplegen personem met relatief veel voorgeschreven consulten hun huisarts wakex dan personen, die 
munder of helemal geen voorschriften hebben op dit punt. Bunen de natr het antal voorgeschreven consulten onderscheiden gropen doen $z i c h$ echtex wel verschillen voor, afharkelijk van de mate warin men tot medische consumptie genelgd is. Personen met een relatief siechte ziektebeleving, een positieve attitude ten aanzien van hun arts of een sterke gedragsintentie gaan waker naar de dokter dan personen met een slechte ziektebeleving, een negatieve attitude ten aanzien van hum arts of een gexinge gedragsintertie.

\subsection{De invloed van het lekennetwerk (deel III)}

Wij bekijken nu het gemiddeld aantal huisartsconsulten van personer met

1. relatief veel resp. relatief weinig mensen in hun omgeving, die wan hun aandoening afweten (omvang lekennetwerk);

2. twee resp. slechts Eên (of helemal geen) direct betrokken lekenadviseur (s);

3. lekenadviseurs, die de aandoening van de respondent relatief goed resp. relatief slecht beleven;

4. meest-betrokken lekenadviseurs, die de patient gezond resp. ziek achten:

5. Lekenadviseurs, die de patiënt veel resp. welnig helpen. Deze kenmerken van het lekennetwerk kwamen in deel III immers als belangrijke determinanten van medische consumptie naar vorem.

Als criterium voor deze tweedelingen geldt voor de onder 1 en 3 genoemde kenmerken weer de mediane warde. voor de overige kemerken komt de tweedeling voort uit de ara van de vraagstelling. Daarbij houden wij opnieuw rekening met het antal voorgeschreven consulten op de hiervoor beschreven wijze. In tabel 16.3 zijn de resultaten samengevat.

De conclusies ult deze tabel zijn deels nog duidelijker dan de conclusies uit de twee voorgaande overzichten. Het meest opwallend en in overeensteming met onze eerdere bevindingen zijn de resultaten met betrekking tot het aantal lekenadviseurs (2), hun ziektebeleving (3.1. en 3.2.), het lekenoordeel over de ziekte (4) en de verleende hulp (5): ongeacht het aantal voorgeschreven controle-consulten radplegen personen met twee direct betrokken adviseurs de huisarts vaker, dan patiënten die 
rabe1 16.3. Gemiadeld antal husarticonsulten nam enkele kemmerki van het lekennetwerk, apart voor respondenten met veel resp. Weinig of geen voorgeschreven consulten

controles kennerk lekennetwerk gem. raacipleegireguentid

w:

(1) onwang lekennetwerk

veel groot netwer.

1.19 26

vee 1 Klein netwerk

1. 12 8

weinig: groot netwerk

0.94 17

weintg kiein netwerk

0.016

16

(2) aantal lekenadviseurs

vee 1 twee

1. 59 29

veel

weinig

een of geen

0.40 10

welinig

twee

1.07

15

eer of geen

0.19

21

(3.1.) ziektebeleving 1 adwiseur

veel.

veel

weinig

welnig secht

1. 50 29

goed

0. 11

siecht

1. 23

13

goed

0.19

(3.2.) ziektebeleving $2^{\text {adviseur }}$

veal

veel slecht

1. 93 15

goed

1.18

11

weinig

slecht

2.00

4

weindg

goed

0.78

(4) oordeel oven aandoenlng $1^{\text {adv. }}$

veel

veel.

weindg

zilek

1.93

gezond

0.74

23

i $\mathrm{i}$

1. 40

5

welnig

greatond

0.45

29

15) mate van hulpverlening door advdseur:

veel
veel
welnig
weinig vere 1 hull $p$

1. 70 7 weindg hulp

0.50 6

vere 1 hulp

1.90 14

weting hulp

1.30 10 
geen of slechts ex advigeur noemden; en eveneris ongeacht het a antal voorgesehreven consulten gat men vaker naar de dokter naamate de lekenadviseurs de andoening slechter beleven, $z 1 I$ de patünt ziek achten of hem veel helpen. Voorts zijn ook de ultkomsten met betrekking tot de omvang van het lekennetwerk (1) in overeensteming met onze verwachtingen, zij het dan alleen birner nax controlefrequentie onderscheiden groepen.

Wij menen hiermee opnieuw steun gevonden te hebben voor onae stelling la hoofdstuk 12: naatiate het lekennetwerk intenslever bif de andoening van een wan de leden ervan betrokken is, neent de medische consumptie toe. Dit vermoedelijk, omdat de persoon in kwestie door zijn lekenadviseurs de patienten- of zilekerol opgedrongen krijgt.

\subsection{Het professionele systeem (deel IV)}

Deel IV ging in op verschilien tussen huisarts- en specia1istpatiënten "Het bleek onder meer, dat de consumptiegeneigaheld van huisartspationten meer invloed heeft op hun bezoeken aan de huisarts, dan de consumptiegeneigdheid van specialistpatiënten op het aantal bezoeken, dat deze aan de specialist brengen. Wh willen daarom voor djt overzicht enkele gegevens ult de voorgaande paragrafen apart voor huisarts- en specilalistpatiënten presenteren (tabel 16.4 .).

De uitkomsten zijn mindex sprekend dan die uit de vorige tabellen. Voor de huisartspatiënten Iiggen zij - op én uitzondering na (1) - wel in de lijn der verwachting: dit zelfs, voorzover na te gaan, ongeacht het aantal voorgeschreven consulten. Voor de specialist-patienten is dit niet het geval. Daar wijzen de resulfaten in die van de acht gevallen ook binnen de naar controlefrequentile onderscheiden groepen in tegengestelde richting. Daarbij kan wel worden opgemerkt, dat de verschillen tussen alle genoemde categorieen niet spectaculaix zijn. over het algemeen blijkt hier echter opnievw, dat de invloed van de consumptiegenelgaheid en enkele kenmerken van het lekensysteem gexinger zijn bijl specialistconsulten dan bij bezoeken aan de huisarts. 
Tabe1 16.4.1. Euisartspatienten $(N=301$

(1) veel controlles voorgeschreven

$$
\begin{aligned}
& \text { ziektebeleving slecht } \\
& \text { ziektebeleving goed }
\end{aligned}
$$

weinig controles woorgeschreven

$$
\begin{aligned}
& \text { ziektebeleving slecht } \\
& \text { ziektebeleving goed }
\end{aligned}
$$

(2) veal controles voorgeschxeven

ziektebeleving $1^{e}$ adviseur slecht

ziektebeleving $1^{e}$ adviseur gaed

weinig controles voorgeschreven

ziektebeleving $1^{e}$ adviseur slecht

(3) veel controles voorgeschreven

attitude t.a.v. arts positief

attitude $t . a \cdot v$, arts negatief

weinig controles voorgeschreven

attitude t.a.v. axts positief

attitude t.a.v. arts negatief
11.60 5

1,00 7

11.08

0.00

(4) verel controles voorgeschreven

groot netwerk

1. 30 10

kieün netwerk

weinfly controles voorgesehreven

groot netwerk

1.11

0.12

klein netwerk 
Tabeil 16.4.2. Specialispatienten $(N=44)$

(1) vel controles voorgerchxeven

ziektebelewing silecht

2.89

19

zinktebelewing goed

2.87

i

weing controles voorgeschreven

alektebeleving sleoht

1.75

4

ziektebrenewing goed

1.77

1.3

(2) vel controlls woorgeschreven

ziektebeleving $1^{e}$ adviseur sleckt

2.74

zlektebeleving 1 acuiseur goed

3.00

6

weinig controles voorgeschreven

ziektebeleving $1^{\text {e }}$ auviseux shecht

1.83

6

ziektebedeving $1^{\text {e }}$ adviseur goed

1. 50

(3) veel controleg voorgeschreven

attitude t. a. w. axts positief

2.92

13

attitude t.a.v. ants negatief

2.86

weintg controles voorgescheven

attitude t.a. $\mathrm{v}$. axts posituef

2.010

6

gututude t.a.v. arto negatief

1.64

i1

(4) vel cantrales voorgeschreven

groot netwerk

2.69

16

kiein netwerk

2.86

7

weinilu controles woorgeschreven

groot wetwerk

2,12

g

klledin netwerk

1.29 
Hoofdstuk 17. Slotbeschouwingen

\subsection{Onderzoeksvragen opnleuw bezien}

Deze paragraaf stelt de onderzoeksvragen, warop deze studie zich richt, tegen de achtergrond van de resultaten opnieuw aan de orde.

1. Is ex sprake van een differentieel effect van verschillende aandoeningen op de consumptiegeneigdheld?

Wij gingen ervan uit, dat de consumptiegeneigdhezd van een patiënt sterker is naarmate zijn (chronischel ziekte ernstiger (levensbedreigender) is. Deze verondersteling werd echter ten aanzien van de hiler onderzochte aandoeningen niet bevestigd: hartinfarct-" sulker- en psoriasispatiënten verschilden onderling niet duidelijk in hum geneigdheid tot het inroepen van medische hulp.

Dat geldt ook voor hun lekenadviseurs: de consumptiegeneigdheid van dezen is evenmin afhankelijk van de aandoening waraan hun patiënt-netwerklid lijdt. Maar dit wel met én duielijke uitzondering: de meest-betrokken adviseur van hartinfarctpatiënten heeft een slechtere ziektebeleving dan die van diabetici, en deze heeft weer een minder goede ziektebeleving dan de eerste lekenadviseur van psoriasispatiënten. Op de mogelijke betekenis komen wij hteronder nog terug.

Men kan concluderen, dat consumptiegeneigdheid, zoals hier geoperationaliseerd, een vrij robuust meetinstrument is, waarmee een betrekkelijk stabiel verschijnsel. wordt wargenomen. Het geheel van attituden, opvatungen er gedragsintenties dat met medische consumptie te maken heeft, geeft vermoedelijk een relatief algemene dispositie tot het inroepen van medische hulp weer.

2. Welke invloed heeft iemands consumptiegeneigdheld op ajn feltelijke medische consumptie?

De invloed van consumptiegeneigaheid op medische consumptie wexd in dit onderzoek duidelijk aangetoond. Gezlen onze on- 
derzoeksopzet lag deze uitkonst in de lijn der verwachting: over het algemeen kwamen wij tot de conclusie, dat de meer emotioneel-evaluatieve componenten van consumptiegeneigdheld (ziektebeleving en de attitude ten aanzien van de eigen arts) voor medische consumptie van grotex belang $z$ in dan de meer cognitieve componenten ervan (opvattingen over ziekte en medische zorg).

Daarnaast bleek, dat deze inwloed verschilt, afhankelijk van de vorm van medische consumptle die men beziet. De invloed neemt af - zo veronderstellen wij - naarmate de door de pationt gepercipieerde soclale afstand tot de persoon of instelling, die hij raadpleegt, toeneemt. De zilektebeleving blijtet daarbij wel belangrijk, maar als de medische consumptie het resultat is van een weloverwogen beslissingsproces - zoals waarschijnlijk bij het radplegen van alternatieve genezers - dan treden cognitieve componenten van de consumptiegeneigdheid (vertrouwen in de medische zorgl op de voorgrond.

3. Welke Invloed hebben lekenadviseurs op consumptiegeneigdneta?

De bevinaingen van het onderzoek zijn op dit punt gevarieerd. De belangrijkste conclusie is dat ex een relatiaf grote overeenstemming in consumptiegeneigdheld tussen netwerkleden bestaat. Voorts bleek - tegen de verwachting in - hulpverlening door netwerkleden de consumptiegeneigaheid van de patiënt te versterken. Tenslotte ontbrak - eveneens tegen de verwachting in - een relatie tussen emotionele steun on de consumptiegeneligdheid van de patient.

Deze wikamsten moten begrepen worden tegen de achtergrond van de resultaten ten aanien van de volgende vraag.

4. Welke invloed hebben lekenadviseurs op iemands feitelijke medische consumptie?

Het onderzoek toont an, dat lekenadviseurs een sterke invloed uitoefenen op lemands medische consumptie. In de eerste plaats doen zij dat op grond van hun eigen consumptie- 
geneigdheid, die duidelijk additoneel - nast die van de patient - bijaraagt tot het inroepen van medische hulp. Voorts beinvloeden lekenadviseurs de patient door hem in zijn rol als patient tegemoet te treden. Als zijhem als patient behamdelen, hem van allerlei hulp voorzien en daarbij hun eigen bezorgaheid tonen, gaat de patient vaker naar de dokter dan wanneer zij dat niet doen. De invloed van de netwerkleden op de medische consumptie werloopt in dit opzicht blijbaax dixect, dat wil zeggen zondex dat de patient zelf tot meer consumptie neigt.

\subsection{Theoretische betekenis}

Wij menen de theoretische betekenis van deze studle an de volgende bevindingen te mogen ontlenen.

1. Consumptiegeneigdheid en medische consumptie, ofwel: de relatie tussen attituden, opvattingen en gedragsintenties en feitelijk gedrag

Deze studie heeft aangetoond, dat attituden, opvattingen en gedragsintenties de medische consumptie wel degelijk beinvloeden. En dat deze invloed zich tot op zekere hoogte los van specifieke $z$ iektebeelden doet gelden.

Emotionee1-evaluatieve detexminanten spelen bij medische consumptie over het algemeen een belangrijker rol, dan rationeel-cognitieve determinanten.

De invloed van attituden, opvattingen en gedragsintenties op de medische zorg neemt toe, narmate de geperalpieerde sociale afstand tot de te radpllegen persoon of gezondheldsw zorgvoorziening afneemt.

Deze invloed is vermoedelijk well afhankelijk wan de mate warin iemand de rol als chronisch patiênt heert anvaara. Marmate dat minder het geval is, alspomeren bepalde geneigdheldscomponenten niet tot probleemoplossend gedrag in termen van medische consumptie. maar zj gaan dan vealeer met stress in termen van psycho-somatische klachten gepaard. 
Tenslotte blijken structurele persoonskenmerken bij de conditie die alt onderzoek stelt, dat wil zeggen bij bekend veronderstelde consumptienoodzaak, een ondergeschikte rol te spelen. Dit geldt voorzover $2 i j$ als deteminanten van consumptiegeneigdheld optreden, alsook voorzover zij determinanten van feltelijke medische consumptie zijn.

- De Irvloed van het lekennetwerk

Rermerker van het lekennetwerk oefenen een additionele inwloed lit op de medische consumptie van een (chronisch) ziek 11 d van dat netwerk.

Deze invloed kont voort uit (1) attituden, opvattingen en gedragsintenties, die binnen het netwerk bestaan en elkar daar vermoedelijk versterken, uit (2) enkele structurele kenmerken van dat netwerk, met name de omvang ervan en uit (3) gedragingen van metwerkleden ten opzichte van elkaar. De mate warin zich deze drie punten doen gelden is tot op zekere hoogte wel afhankelijk van de ard van de aandoentng: naarmate deze ernstiger is neemt de invloed ervan toe. Dit is voornamelijk te begrijpen vanuit de theorie met betrekking tot het patientenrolgedrag en het belang dat "somatische fixatie" van de netwerkleden daarbjj heeft.

Samengevat steunt dit onderzoek de gedachte, dat netwerkkenmerken naast sociaal-psychologische kenmerken een duidelijk zelfstandige invloed ultoefenen op medische consumptie. Dit geldt zowel bepalde culturele als bepalde structurele kenmerken van het netwerk.

Toekonstig onderzoek zal moeten ubtwijzen, of deze bevindingen ook gelden onder andere condities, dan de hier gestelde. Men kan zich met name afvragen, of de uitkomsten ook van toepassing zijn op primalre sociale netwerken, warin alle leden (min of meex) gezond zijn, en watin medische consumptie plats vindt ten gevolge van acute of nileuwe aandoeningen. Het feit dat drie duidelijk verschillende aandoeningen niet verschillend op de consumptiegeneigdheld inwerken doet ons vermoden, dat dit in wergaande mate het geval zal zijn: 


\subsection{Nethodische betekenis}

Voor deze studie is een zeer gerichte onderzoeksopzet gekozen, die in meer dan een opzicht wruchtbar 1 s gebleken.

In de eerste plaats heeft homogenisering ran de steekproef ertoe geleid, dat het door ons te bestuderen verschijnsel relatief goed onderzoekbaar werd. Het onderzoek heeft angetoond, op welke wijze consumptiegeneigdheid medische consumptie beInvloedt en welke rol netwerkleden daarbij spelen. Voorts is het door de opzet mogelijk gebleken, on de rol die de consumptienoodzaak in studies naar determinanten vam medische consumptie speelt, verregaand gelijk te schakelen. Binnen dat kader kon een eventuele invloed van bepalde iektebeelden op attituden, opvattingen en gedragsintenties naukeurig worden nagegaan.

In de tweede plaats werd voor het onderzoek informatie over. Een persoon ook ingewonnen via anderen, hetgeen de mogelljkheid bood om (1) gegevens met betrekking tot dezedfde verschijnselen te vergelijken en voorts om (2) netwerkkenmerken te kunnen warnemen, zoals de homogeniteit in denkbeelden. zoals in diverse hoofdstukken bleek, speelde daarbij de informatie, Ingewonnen bij artsen, een belangrijke rol, die in de meeste ondexzoeken naar determinanten van medische consumptie ontbreekt. Door de onder (1) genoemde vergelijkingsmogelijkheid kon de problematiek van het verschil tussen "objectief" en "subjectief-ervaren" gezondheidstoestand - ofwel: tussen "disease" en "illness" - tot op zekere hoogte opnieuw belicht worden.

De opzet kent uiteraard ook nadelen. Een relatief klein aantal waarnemingen vereist voorzichtigheid bij de toepassing van bepaalde statistische analysemethoden. Wij hebben op bepaalde punten de verleiding om enkele van deze technieken te gebrulken niet kunnen weerstaan, maar menen ten aanzien wan de belangrijkste conclusies de nodige voorzichtigheid te hebben betracht.

voarts heeft ons onderzoek betrekking op warnemingen wan een tijastip, zodat ten aanzien van de volgorde warin bepalde verschijnselen optreden slechts veronderstelifigen konden worden geformuleerd.

Tenslotte heeft een onderzoek onder duldelijk omschreven condities - naast het voordeel, hypothesen vilj precies te kunnen toetsen - het nadeel, dat de relkwijdte van de bevindingen 
relatief gering $1 \mathrm{~s}$. Wanneer deze bevindingen echter duidelljk ansluiten bij die ult exder onderzoek, en wanneer de resultaten een zekere mate van plausibiliteit bezitten, weegt dit bezwar ons inziens niet op tegen de eerdergenoemde voordelen.

\subsection{Maatschappeliske betekeris}

ook al stat bij een studie als deze de matcshappelijke relevantie niet voorop, wij menen daaruit toch enkele belangrhjke conclugles van meer praktische betekenis te mogen trekken.

In deel I werd betoogd, dat - zo men medische consumptie al kan beinvloeden - men daarbij de consumptiegeneigaheid als a angrijpingspunt zal moeten kiezen (naast het voorkómen van zlekte). Wu ons onderzoek het relatieve belang van die geneigaheid duidelijk heeft aangetoond, kunnen wij hierover meer precieze uitspraken doen.

In de eerste plaats bleek, dat emotioneel-evaluatieve geneigaheidscomponenten over het algemeen belqngrijker zijn dan cognitieve. Daaruit mag men afleiden, dat voorlichting en pogingen tot kennisoverdracht in verband met medische zaken alleen de feitelijke medische consumptie slechts in beperkte mate zullen beinvioeden. Pxikkels, aie op de meex emotionele componenten weten in te spelen, zullen daarvoor warachijnijjk belangrijker zijn.

Een tweede bevinding uit ons onderzoek wijst exop, dat de huisarts op dit punt en belangrijke rol kan spelen. Het bleek immexs, dat de consumptiegeneigdheid de relatief belangrijkste rol speelt bij huisartspatienten die hum huisarts raaplegen. wij zijn van mening, dat de huisarts dit feit zou kunnen benutten om te proberen (te) veel en wellicht onnodige medische consumptie var patiënten tegen te gan doox bijvoorbeeld hun ziektebeleving in positieve zin te beinvloeden. Hij zou erop kunnen wijzen, dat bepaalde ongemakken nu eenmad bij - in dit geval een chromische andoening hoxen of - algemener - , dat "klachten en ziektesymptomen bij onze gezondheid horen" (Iuygen, 1977). Voorts - en dit punt brengen wij hier als derde naar voren zou de (huis)arts de lekenadviseurs meer bij zijn behandeling van iemands andoening moten betrekken. Het ondexzoek heeft opnleuw duidelijk gemakt, dat gezins-en familieleden iemands 
medische consumptie op vrij directe wijze beinwloeden. Dit geldt vooral voor de meest-betrokkene, die warschijnlijk door enkele geruststellende woorden van de (huis) arts de aamdoening van het zieke netwerklid relatief beter zou beleven, dan wanneer hij of zij tot "verzorgen" of wellicht tot "vertroetelen" wordt aangezet. Dat geldt vermoedelijk ook voor de tweede lekenadviseur, die door een wat afstamdelijker houding ten anzien van de aandoening in eerste instantie het patientenrolgearag minder zal versterken dan de meest-betrokkene. De (huis)arts zou ook op diens inzet beraep kunnen doen " om zogenaamae somatische fixatie binnen het lekennetwerk tegen te gaan.

Deze conclusies zijn overigens in hun algemeenheid ndet nieuw. zij werden bijvoorbeeld uitstekend verwoord door Huygen (1977). Wij wllen naar a anleiding van ons onderzoek vooral benadrukken, dat (1) de invloed van de (huis)arts in deze vooral via emotionele prikkels en niet via woorlichting alleen zal moeten verlopen en dat (2) de rol en positie van een tweede lekenadviseur in het netwerk mede kan worden gebruikt, om somatische fixatie tegen te gaan.

onze resultaten maken wel duidelijk, dat pogingen om informele hulp vanult iemands netwerk te bevorderen look wel mantelzorg" genoemd, Hattinga verschure, 1979) ook een keerzijde kennen. Dit soort pogingen zijn op zichzelf belangrijk " maar zij kunnen er snel toe leiden, dat zij in "teveel zorg" resulteren, dat wil zeggen in overbezorgaheld en daarmee in versterking van iemands rol als patiënt. ons onderzoek heeft deze keerzijde duidelijk aangetoond.

De overige bevindingen van matschappelijke betekenis baseren wij op deel. IV van deze studie. Wij meenden te mogen concluderen, dat chronische patienten in bepalde gevallen warschijnlijk zonder duldelijke reden onder behandeling van specialisten staan in plaats van onder behandeling van de huisarts. Daarbij komt, dat patienten zelf met deze behandeling minder tevreden zijn, dan huisartspatiënten. Mede gezien het voorgande benadrukt deze bevinding - en dit is ons vierde punt opnieuw het bellang van de eerste 1 ijn in de gezondheidszorg en de rol, die de huisarts daarbij speelt of kan spelen. 
Tenslotte bleek uit deze studie niet - zoals veelal wordt aungenomen - dat ziekenfordspatienten sterker tot medische consumptie geneigd zouden zijn dan particulier-werzekerden. Men mag daruit afleiden, dat de invloed van de verzekeringsvorm op medische consumptie duldel1jk afneemt zo niet verdwijnt. gegewen een zekere consumptienoodzaak. 


\section{SUMMARY}

Why do some people with certain symptoms go to the doctor, whilst others with the same symptoms do not?

This is a question which occuples many research workers. our study is an in-deptin elaboration of findings made by others in this field. We are not interested in the principal reasons for consulting the doctor - for the most part this is already known from other research work - but the reasons which are not perhaps the most important, but about which little is as ret known and which are to a certain extent susceptible to influence. Thus in this study the emphasis is on (1) the attitude which a person has towards slckness and medlcal care and (2) the influence of members of the family and frlends, also referred to as network members or lay advisers "on visiting the doctor.

For the purpose of studying these two phenomena a research design was chosen whereby other reasons for visiting the doctor were as far as possible controlled. We studied persons who were known to be suffering from a particular chronic allment and who were under seventy years of age. Part I of the book qoes more closely into this theoretical background to the study. The subject is elaborated in greater detall and indications are given as to why certain syndromes have been brought into the study. The guide lines for the cholce were principally the degree of urgency of the complaint, the extent to which it threatened the patient"s 11 fe and caused pain and hinderence and the rellef which the patient can expect from medical treatment. On the basis of these criterla sudied people

- who have had a heart attack (high degree of urgency and dependent on the stage of the 11 iness relatively migh degree of benefit from medical treatment)

- With diabetes (less high degree of urgency and usually some degree of benefit from medical treatment)

- wth the skin disease psorliass (relatively low degree of urgency and usually iftie benefit from medical treatment. 
chapter 4 shows the way in which these people were sought out and how the ultimate respondents were chosen from the group of patients who were prepared to participate in the actual enquiry.

For the second part of the subject of this study - the inEluence of members of the family and friends on visits to the doctor - we also wanted to put questions to a number of people who were closely involved with the iliness of the patient-respondent. Thus each patient was asked auring the interview to name two people who would also participate in the enquiry. Finally the patient's consent was obtained to be allowed to ask the doctor attending him for some supplementary medical details.

In this way we have at our disposal information from thrice twenty five patient-respondents, from 111 most closely involved lay consultants and from 68 dactors ${ }^{11}$. Chapter 4 gives more details on this.

part II deals with the attitudes towards iliness and care. In the literature these are sometimes also referred to as "predisposition to medical consumption". Chapter 6 goes into the theoreticall significance thereof and the way in which we have measured these attitudes, beliefs and behavioral intentions. The emphasis here is on subjective information from the patientrespondent, which is as far as possible recorded independent of the objective seriousness of the iliness. In chapter 7 we give the results of the study with regard to the first question: how does the predisposition to medical consumption influence our patient-respondent"s visits to the doctor?

In answering this question we have paid a great deal of attention to the influence of the nature of the chronic illness. contrary to our expectations it appeared that heart attack pam tients, diabeticl and psoriasis patients do not differ in their attitudes towards illness and care. In other words: heart attack patients are not in general inolined to call in medical help any earliex than diabeticl, who in turn are neither more nor less inolined to do so than psoriasis patients. From this we could conclude that the predisposition to medical consumption is scaxcely determined $1 f$ at all by the nature of a person's (chrontid 11lriess. 
The influence of predispostion to medical consumption, 1.e. a person's attitudes towards illness and care, on his going to the doctor is consilerable. In particular the nore enothonal aspects thereof - the way in which a person experiences his illness and his satisfaction with his own doctor - determine the number of doctor's visits to a great extent. More rational aspects - a person's beliefs about iliness and medical care in general - play a minor part.

In part III we go into the influence of the lay consultants on visits to the doctor. The information on their opinions on sickness and care was gathered in such a way that we were able to compare it with that of the patient-respondents. It appearea that the predisposition to medical consumption of our patientrespondents and that of their lay advisers, as well as the predisposition amongst the lay advisers themselves, corresponded to a great extent.

The most important conclusion in part III is that people who are close to a (chronic) patient can in various ways exert a Fairly strong influence on his predisposition to consumption and his doctor's visits. The more serious the illness, the more this applies. For it is then that there are more people involved in the patient's affairs, who all exert the ir influence. The more these people help the patient-respondent with ali sorts of matters connected with his illness, the more contact he has with his G.P.. On the other hand, if the lay advisers consider the patient to be healthy inspite of his illness, then he goes to the doctor less. These conclusions apply up to a certain point regardiess of the seriousness of the 1 iness.

These findings are very $11 k e l y$ attributable to a certain degree of over-anxienty on the part of the family and fxiends of the (chronicaliy) sick person. This over-anxiety finds expresston not only in (too) much help and assistance, but allo up to a point in a greater degree of predisposition to medical. consumption by the lay corsultants.

Part IV deals with the consultations with dootors an greater detail. Some of the patient-respondents are under the care of a speciallst, whilst others are treated by the G.P.. Further 
some patient-respondents have a great deal of contact with (vartous) dactors, whilst others do not mention these contacts or only to a lesser extent. Moreover some patient-respondents have sought so-called unorthodox methods of healing for their complaint, whist others have not All these forms of medical consumption are dealt with in the last section.

It appears over and over again that the attitudes of the patient arid his immedite circle towards iliness and care exert thifuence thereon. This genexal judgement may be qualified by sayling that the more formal and impersonal the contact between the patient and his immediate circle and the doctor or the medical body, the less important the part played by predisposition to medical consumption in consulting them. The influence of the predisposition to medical consumption is the greatest in the case of G.P. patients consulting the G.P. For patients of specialists this applies to a lesser extent.

Visits to practitioners of unorthodox methods of healing were not found to be the outcome of dissatisfaction with a person"s own doctor, on the contrary: those who consult, or conslier consulting, these practitioners are precisely the people who are very pleased with the treatment provided by their own doctor. We assume that they recognise the ilmitations of medical sclence in dealing with their disease and that they do not hold their own doctor responsible, but value his efforts all the more,

Finally it appeared in part IV that there is no difference in prealsposition to medical consumption between health insurance patients and those privately insured, nor do they differ In the degree to which their predisposition to medical consumption influences their visits to the doctor.

The last part summarises the princlpal conolusions once more. The study makes $1 \mathrm{t}$ clear that both a person"s attitudes towards lilness and care and also the influence of his family and friends affoct his visits to the doctor. The infiuence is above all of an emotional nature anxlety, uncertainty, (too much solicltude are probably to the fore. The nature of the petson's 11 Iness plays a subordinate role here. In treating 
(chronic) patients this is perhaps still not taken sufficlenty into account. We consider that the G.P. in particular has an important task here, since he is relatively closely involved with the patient and especially with the patient's immediate circle.

1) The material Erom the interviews was put at our disposal by the social and Cultural plaming offlce (R्Ajewijk). It was collected by the Institute for Applied Sociology (NiJmegen). 
L I T E R A T U U R 


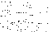

20 


\section{LTERATUUR}

Andersen, R.A., Behavioral Model of Eamilies" Use of Health Services Research series nx. 5, cambridge, 1968

Anderson, R.S., et. al., Evaluation of clinical, oultural and psychosomatic influences in the teaching and management of atabetic patients. in: American Journal of Medical Setence 245, 1963, 2. $682-690$

Argster, H. von e.a. Vertrauensartztliche Exfahrungen aus Nachuntersuchungen an 405 Infarktpatienten in 6 Jahren. In: Arbeitsmedizlin, Sozialnedizin, Pxäventivmedizin, 3, $1977, p=64-66$

Apple, D. How layman define iliness. In; Journal of Hed th and Human Bellavior, 1,1960, D. $219-225$

Archer, M. e.a., social factors affecting particlpation in a study of diet and coronary heart disease. In: Journal of Health and Human Behavior, 8,1967, D. $22-31$

Barnes, J.A. Networks and political process. In: J.C. Mitcheli, ed., Social Networks in Urban Situations, Manchester, 1969, p. 51-76

Becker, M.H. e.t., Selected psychosoclal models and correlates of individual health-related behavlox. In: Medfeal Care, Vol.Kv, mr. 5 , suppl., 1977, p. 27-46

Becker, M.H., e.a. The Health Belief Model and prediction of dietary compliance. In: Jourmal of Health and Social Behavior, 18, 1977. R. $348-366$

Ben-sira, Zeev, Involvement with disease and health pronoting behavior. In: Social Science and Meducine, Vol. 11, 1977, p. 165-173

Ben-sira, zeev, The structure and dymamics of the image of diseasies. In: Journal of Chronical Diseases, Vol. 30, 1977, p. 831-842

Bexgsma, J. "Somatopsychologie, Irochem, 1977

Bloks, $B$. en $S$, tan de Graaf-van der Linden, Vakgroep klinische Psychologie, Vxife universiteit, Het effect van een gespreksgroep voor diabeten, doot. scriptie, Ansterdam, 1973

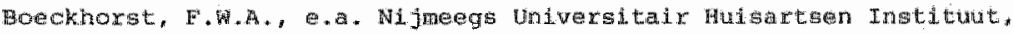
Aspecten van somatische fixatie in gezinnen, Ni jomegn, 1977

Booth, A. en N. Babchuk, Seeking bealth cere from new resoureas, In: Journal of Health and social Behavior, $13,1972,{ }^{\circ}, 90-99$

Bott, E., Eamily and Social Network, wondon, 1957

Bremer, G.J. en W.J. de Grabe, poriasig in de huisartsprakijk. In: Korte, J. de, Mensen met psortasts, vtrecht, 1977, p. 23

Eremer-Schulte, M., red. Samen beter worden, Alphen aan den Rijn, 1980 
Eruhn, J.G. frefects of chronic 11 iness on the family. In: Journal of Family Practice, Vol. 4, ar. 6, 1977, P. 1057-1060

Callahan, E.k. et. al., The "Shok Rolle" In chronic illness: some reactions. In: Journal of Chronle Disease, 1966, D.883-897

Cartwright, A. " Satients and Their Doctors, London, 1967

Cassed, E. Th. Wair de doktex, Hegpe 1, 1973

Centraal Burau voor de Statistlek en Soctal en Cultureel Planburean, Leefsituat leonderzoeken, 1974 an 1977

Central Bureau voox de statistiek en T.N.0., Hart-en vaatziekten. den Hag, 1980

Commlas Altematieve Geneswijzen (Comigsie Muntendam), Alternatieve Geneeswitzen, den Haag, 1981

Cowie, B., The caralac patient"s pexception of his heart attack. In: Saclad. Selence and Mediche, Vo1. 10, 1976, p. 87-96

Davis, M.S., Predicting non-compliant behavior. In: Jourmal of Health and Soctal Behavior, Vol. a, 1967, D. 265-271

Dlabetes Veieniging Nederland, Diabo, mandelijks voorlichtingsblad van de DVN, Jxg. 33, 34 en 35, resp. 1979, 1980 en 1981

Dirken, J.M. "Arbetd en stress, Gronungen, 1969

Doehrman, S.R., Psycho-social aspects of recovery from coronary heart disease: a review (1968-1975). In: Soctal Sclence and hedicine, Vol. 11, $1977, p .199-218$

Doorn, J.A.A. en C.J. Lanmexs, Moderne Sociologie, dertiende herziene druk, utrecht/Antwerpen, 1976

Deorn-Janssen, M.J. van, project gezin en Eamilie, vtrecht, 1971

Duller, $p$. Aamwezigheid psoriasis in totale bevolking. In: Nepv nieuws, 1e $1 \mathrm{rg} . \mathrm{nx}$. 4, 1980

Dunning. A.J. Het hartinfarct, Amsterdam, 1966

Dijk, P. van, Geneeswijzen in Nederland, Deventer, 1976

Difl, H. Wan, Hartinfarctpatienten en sociabiliteit. In: Fifdschrift woor Soctale Geneeskunde, $56,1979, p .443-447$

whrlich, H.J., Attitudes, behavior and the interwening variables. In: The American Sociollogist, 1969 , p. 29-34

Elchinorn" 1962. geciteerd door Levine en Kozloff (1979)

EIInson, J. en R.E. Trussell, Some factors relating to degree of correspondence for diagrostit information as obtained by household interviews and chinical examinations. In: American Journal of Public Health, 47 . $.957,0.311-321$ 
Ellemers, J.E., Veel kunnen verklaren of iets kunen veranderen: krachtick versus manipuleerbare variabelen. In: Beleld en Matschapp11, 11, 1976. Q. $281-90$

Emans, B., Aktie-onderzoek, attitudes en gedrag. In: WIIke, H, G.J. Kok, red. Saciale psychologie in verandering. Alphen an den Rilj, 1978

Es, J.C. van, woord vooxaf bij Geneswijgen in Nedexland, van Dujk, 1976

EVAC: Evaluatieconmissie Bevolkingsonderzok cerwixcarcinoom, Eevolkingsonderzoek op cextixcarcinoan in de proefxegio's Nijmegen, Rotterdam en Utrecht, Leiden 1980.

Eijk, J.Th.M. van, Levensgebeurtenissen en ziekte, diss. Utrecht, 1979

Farge, E.J. Medical orientation among a Mexican-American population: ar old and a new model reviewed. In: Social science and Medicine, val. $12,1978 \times p .277-282$

Feldman, J.J. Fhe dissemination of health information, Chicago, 1966

Festinger, L. A theory of cognitive dissonance, Evanston, I11, 1957

Finlayson, A., social networks as coping resources. In: Soctal science and Medicline, Vol. 10, 1976, p. 97-103

Fishbein, M., Readings in Attitude Theory, New York, 1967

Fishbeln, M. en I. Ajzen, Belief, Attitude, Intention and Behavior, Addison-Wesley, Mass., 1975

Freidson, E., Patients' Views of Medical Practice, New York, 1961

Freidson, E., Profession of Meaicine, New York, 1975

Friledman, M. e.a., Development of an objective psychological test for the determination of coronarymprone behavior pattern in employed men. In: Journal af Chronic Disease, 20, 1967, P. 371-379

Friledman, M. en Rosenmen, Pathogenosis of Coronary Artery Disease, New York, 1969

Froland, ch. e.a., Social Support and Social Adjustment: Implications Eor Mental Health Professionals. In: Community Mental. Health Journal, Yol. $15(2), 1979,0.82-93$

Garg, I. van der, An Econometric Analysis of the Dutch Health Care System, diss., Leiden, 1978

Cadourek, I:" Sociologische onderzoekstechnieker, Armhen, 1967, p. 201

Gartity, Th.F. et, al., sactors Influenoling Self-agsessment of Hedth. Im: Social Science and Medicine, Nol. 12, 1978, P. $77-81$

Geertsen, R. e.a., A re-examination of suchman"s Vi,ws on Sicial Factorg in Health Care Utilization.. In: Journal of Health and Social Behavior, 16. 1975, D. $226-237$ 
Glel, R., Het diluna van de medische beroepsuitoefening. In: Hequsch contact, 31,1975, D. $1021-1026$

Giesbers, N. e.a., Media en medichinen, I, Iiteraturowerzicht. In: Medisch contact, $32,1977, \mathrm{p} .1467-1472$

Gochuar, D.S.s The Organizing Eole of Motivation in Health Bellefs and Irtentions. In: Journal of Hea 1th and Soclal Behavior, 13, 1972 .

p. $285-293$

Gordon, G., Hole Theory and Il Iness, Hew Hawer, Conr., 1966

Graaf, $\theta$. de, Levensecht toegepast onderzoek. In: Intermediair, l6e jro$44,1980,2.49-59$

Grenley, I.R. en M. Mechenic, Social Selaction in Seeking Help for Psychological problens. In: tovinal of Gedith and Soctal Behaulor, 17 , $1976 \cdot 1 \cdot 249-262$

Groen, J.J. en W.S. de Loos, Pgychosomatiohe aspecten van diadetes melutus, Ansterdan, 1973

Groot, A.D. Methodologie, den Baag (4e aruk), 1968

Guilford, J.P., Psychonetric Methods, New York, 1954

Warberden, $P$, wan eni R. Lafaille, red. Zelthulp: een nieuwe worn yan hulpverlening den Hag, 1978

Hettinga-Vexschure, $\pi$. zorguerlening in beweging, Lochem, 1979

Heydendae 1, P.H.J.M. . a.. Gezin en ziekte, Nijmegen, 1972

Hochbaum, G.M. Public Participation in Medical Sereening programs:

A socio-Psychological study, Public Health service Publication Mr. 572 , Washington, 1958

Hoeksma, B.A., De polikliniek als schakel in de gezondheldszorg. College voor ziekenhuiswoorzieningen, Utrecht, 1979

Hogexzeil H.t. W.., Health Care Policies and Macrombagnostic Groups. In: Tijaschrift voor Sociale Geneeskunde, 44, 1966, p. 77-8B

Horst, F. van der, red., Diabetes; zilok of gezond, Assen, 1980

Forgt, $F$, van der w Meulders, Een beetje suiker, voorciracht C.N.I. Didoetes, 12-13 november 1980. (Rijkmivarsiteit Luburg)

Hoxwitz, A., Fandy, Kin and Friend Networks in Psychiatric helpseeking. In: Social. Sclence and Mealcine, Vol, 12, 1978, p. 297-304

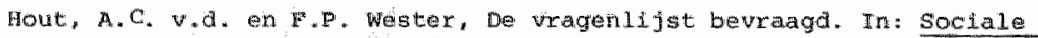
weterischappen, $20,1977, p .259-269$

Howard, A, en R. Scott, Models of Stress. In: Levine, S. en N.A. Scoteh, Soclal Stress, Chlcago, 1970 
Huismans, $s$. De relevantie van warder voor de prediktte fan toekonstgericht politiek gearag, Vrije uniwersiteit Amsterdan, 1979 longepubliceera)

Hinlka, B.S. e.a., Satisfaction with Medrcal Care in a low Incine Population. In: Joumal of Chronic Disease, 24, 1971, D. 661-673

Mulka, B.S. e.a., Practice characteristics and quality of primary Health Care: the Doctor-Patient kelationship. In: Medical Care vol. 13, 1975, p. $808-820$

Huygen, F.J.A., Een visie op onze gezondheldszorg vanult de earste ilijn. In: Mosse1, D.A.A. e.a., Waarheen omet onze gezondheidszorg? Ba:arn, 1977, D. 22-38

Huygen, F.J.A., Family Medicine, Nijmegen, 1978

Jessen, J.I*, Medische Consumptie, Sociologisch Instltuut Rijksumiveraiteit Groningen, Graningen, 1974

Jong, G.A. de, red., Ongelijkheld in gezoncheid en gezoncheldszorg, suppl. bij het Tijaschrift voor Sociale Gereeskunde, Jrg. 58, 1990

Jonkexs, R., Gezondheldsgedrag. Studiecentrun sociale oncologie. Rottexclam 1978

Kasl, S.V, en S, Cobb, Bealth Behavior, Xllness Behavior, and Slck-Role Behavior. In: Archives of Enviramental Flealth, Nol. 12, 1966. P. $246-266$ en $531-540$

Kegeles, s.s., Why people Seek dental Care: A Test of a Conceptual. Formulation. In: Journal of Health and Hunan Behavior, 4, 1963. p. 166 e.v.

king, S.H., Perceptions of I1lness and Medical Practice, Wow York, 1962

Kinlay, S.B. MC, Some Approaches and Pxoblems in the Study of the Use of Services - An overvilew. In: Jourmal of Health and Socila Behavior. 13. 1972, p. 115-152

Kinlay, J.B. MC, Soclal Networks, Lay Consultation and Help-Seeking Behavior. In: Social Forces, 51,1973, p. 275-292

Wirscht, J.P., The Health Belief Model ard Illness Behiolor, In Health Education Monographs, 2, 1974, p. $387 \mathrm{e} . \mathrm{v}$.

Knipscheex, C.P.M, Oude mensen en hun sociale ongeying, der Haag, 1980

Kok, G.J., Attitudes gen gedrag. In: Wilke, H. en G.J. Kok, rad., Sociale psychologie in verandering, Alphen aan den fijn, 1978

Korte, J. de, red. Mensen met Psoriasis, itrecht, 1977

Kosa, J. In I.S. Robextson, The Social Aspects of Health and Iliness. In: Kosa, J. en I.K. Zola, eds., poverty and Health, Cambrldge, Mass. 
Wuther, B. er. Gordon, Seeking Care for Cancex. In: Journal of Eealth

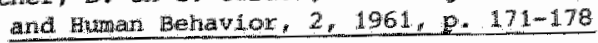

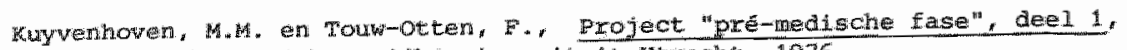

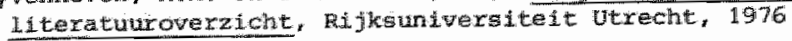

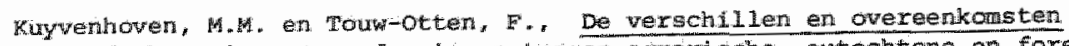

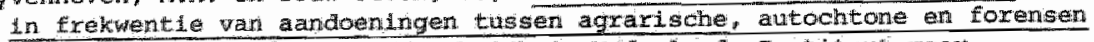
gezinner in eer plattelandsoraktjk in wederland, Institur woor Huis artsengeneeskurde, verecht, 1979

Lambets. H. De morbiditel sanalyse - 1972 aoor de gropepprakt jk onmoord: een niewe ordening van ziekte- en probleangedrag voor de huisartsengeneskunde. In: Huikarts er wetenschap, (I), 17, 1974, P. 455-473, (II), $18,1975, \mathrm{p}, 7-39$, (III), 18, 1975, P. 61-73

Langlie, J.K, Social Networks, Wealth Beliefs, and Preventive Dealth Behaior. In: Journal of Health and Social Behavior, Vol. 18, 1977, e. $244-260$

Levine, S. and M.A. Kozlot, The Sick Role: Assesment and owerview. In: Annual Review of Soc10logy, Vol. $4,1978,0.317-343$

riska, A.En, Emergent Issues In the Attitude-Behavior Consistency Controversy. In: Anerican sociological Reviet, Vol. 39. 1974, D. $261-272$

Liska, A. "The consistency Controwexsy, Reading on the Impact pttitude on Behavior, New York, 1975

Litman, Th. J., The Frinly as a Basts Unit ln Health and Medical Care: a Soclal-Beharioral overview. In: Soctal Scienese and Medicine, Vol. 8, $1974 \times p \cdot 495-519$

Loon, A.J. van en H.G. Schmid, Opnieut de artsomatient relatie. In: Medisoh Contact, $32,1977, p .274-276$

Wudig, E.G. en G. Gibson, self peroption of Slckness and the seeking of Medical Care. In: Journal of Heateh and Social Behavior, 10, 1969, p. $125-133$

Maas. F.J. van der en A.J.W. Wrijlandt, Geintegreerd Milieuonderzoek Rijnmond, bijlage m.b.t. de gezondheidsbeleving, ziekte-eraring en

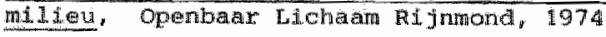

Mam, P.J. van dex, Arbeidsveruim en arbeldsongeschiktheid In verbard

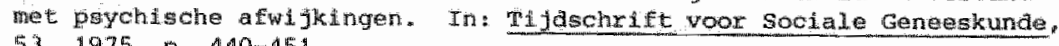
$53,1975, \mathrm{p}, 440-451$

Ma11, J.W.H, E..., De behandeling Van parlasis. In: Nederlands Jijesarkt voox Geneeskunde, 119,1975, p. 89 e.v.

Mechante, D. Medigaj Sociology, New Work, 1969

Melker R.A. de, verwijon door thusartsen nar medische specialistem. In: Nederlands Huisartsen Institudt, Hollend naar de Horizon, Utrecht 1.979. p. 79-90 
Merton, R. 1.7

Metz "W. " P1jn, een teer punt, wjuerk, 1975

Miller, M. I., Seeking Mavice for Cancex Symptoms. In Amexican Jonirna of Public Health, Vol, 63, 1973, P. $955-961$

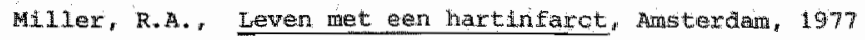

Mtche11, J.C. ed*, Social Wetworks in Utban Situations, Manchester, 1969

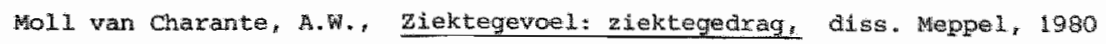

Moor, P. de en J.J. Witte, Diabetes Mellitus, Leiden, 1967

Mootiz, M., ziekenfondsdidmatschap en het raaplegen van de huisarts. In: Medisch Contact, 33,1978 , D. 1465-1468

Mootz, M., Sociale indicatoren, gezondheidstoestand en verzekeringsvorm. In: Medisch Contact, 28, 1980, p. B57-360

Nauta, A.P.N., Contact en controle tussen buren, Aphen aar den Rijn, 1973

Nederlandse Bond van Psoriasispatianten verenigingen, MBpv-nieuws, le en 2 e jxg., resp. 1980 en 1981

Wederlandse Eartstichting, Vrabgbaak voor In Earctpatienten * Exerptia Medica, Amstexdam, 1974

Nederlands Huisartsen Instituut, Hollend nar de Morizon, utrecht, 1979

N.V. v/h Nederlandse stichting voor Statistiek (NsS), NSS Omibus Service, Rapport 07385 , jamuri 1979, onderzoek inzake bepalde patidntencategor:eën, onglepublicuerd

Neven, E.J.⿲丿丨. Uitsteldur en praktijkvoering, a1ss. Asten "1980

Nevaard, A.C., Naar een model voor compliamce-gedrag, owerdruk ult "Opste 1len 2", bunded van de vakgroep methoden en technieken, Soclologisch Institut, Ieiden, 1976

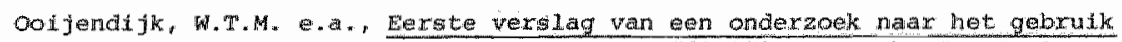
vian en tevredenheld met alternatieve en officle ge geneeskunde, serie "Wat heet beter" nir. 9, HLIveretim, KRO, 1980

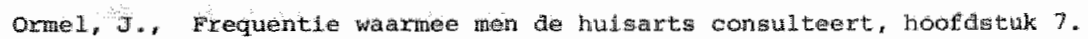
In: Jessen, J.L. Medische Comsumpte, Sociologigch Instituht, Ridks* universitedt Groninger, Groningen, 1974

Ormel, J., Moelte met leven of een moeilijk lewen, das. Grondngen, 1980

Parsons, $T$, The Social System, London, 1951

Parsons, $T$." The Sick Role and the flole of the Psysician Reconsidexea.

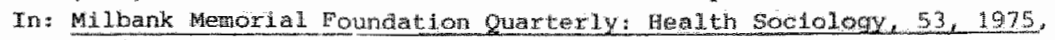
p. $257-277$ 


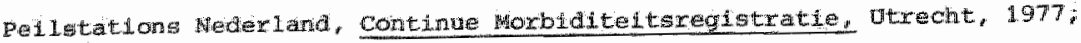
$1978 \div 1979$

Pelt, L. van, De soclale gevolger van psoriasis, doct.sex. Nujagen, 1976

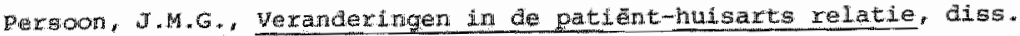
Wijnegen: 1975

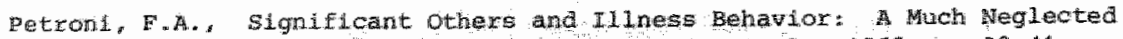
S1ck Role Contingency. In: Soclological Quarterly. 1969, p. 32-41

Dhillpsw, A, Aftezigheda wegens ziekte, Groningen, 1969 (a)

Phidipen, H., Steekproeven, Leiden, 1969 (b)

Philipsen, H, Levensfase generatide en ziekteverzulm, Leiden, 1977

P1oeg, H.M. Wan dex, Persoonlijkheid en medische consumptie, Lisse, 1980

Foolj, M., en A. Lutjes, Leven als diabeet, Lochen, 1977

Ponmer, E.P. en C. San Prag, satisfacte en lieefsituatie, Sociaal en culturea Planbureau, cahier nx. 13 , Rijswijk, 1978

Faphat, 些琶, Commity Structure and Acceptance of Psychiatric aid. In: Mnertcan Journa of sociology, 69, 1964, p, 340-359

Feek, J. van e.a., Subjective complaints and lood Pressure, (nog njet

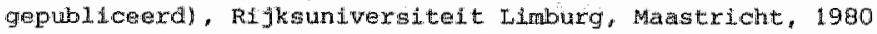

Regan, D.T. and R. Fazio, on the Consistercy Between Attitudes and Behavior: Look to the Method of Attitue formation. In: Journal of Expeximentad Social Psychology, 13, $1977,0,28-45$

Rosenblatt, D. en E.A. Suchman, Blue Collar Attitudes and Information toward lealth and Iliness. In: Shostak, A.B. en W. Gonberg, eds. . Glue Collar Worla, New Jersey, 1964

Rosengtock, I.M., Mhy people Jse Health Sexvices. In: Milbank Memorial Foundation quaterery, 44, 1966, $9.94-124$

Rosenstock, I.M., "The Health Belief Model and Prowarive Action. In: Health Education Monographs, vol, 2,1974, p. 354-386

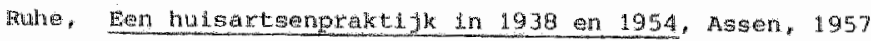

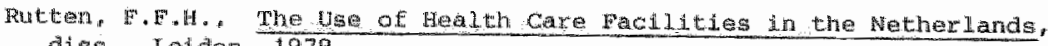

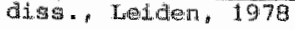

Salloway J.C. am P. D. DIon, A Comparison of Famdiy Networks and Fiend Wetworks in Health care utilization. Tn: Journal of Comparitive Es a 12 studies, $4,1973, \mathrm{p}, 131-142$

Seley, H. The Stress of Life, New rork, 1956

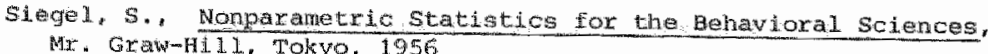


Shuwal, J.T., The Sick fole in a settring of Comprehensive Medical care.

In: Medilcal Care, Vol $, 10,1972$, D. $50-59$

Smits, A.J.A., Kind, hwisarts, gezin, diss. , Nojmegen, 1978

Social en Cultureel Planbureau, Soclad en cultureel Rapport 1978 en 1980, den Faag, resp. 1978, 1980

Spruit, I.P. e.a., Deelname aar een screeningsondersok op borsthanker. In: Intermediair. $53,1976, \mathrm{p} .15-19$ en $52,1978, \mathrm{p}, 1-11$

Spruit, I.P., Opkonstgedrag bij bevolkingsondexzok op borstkanker te Leiden. In: Tijuschrift Sociale Geneeskunde, $57,1979,2.784-795$

Stern, M. A.a." Psychosocial Adaptation Following an Acute Myocaralal Infarction. In: Journal of Chronic Diseases, Vol. 29, 1976, p.513-526

Stimson, G.V., Obeytng Doctor's Orders: A view From the other side. In: Social Science and Medicine, Vol. 8, 1974, 20.97-104

Stoeckle, J.D. e.a., on Going to See the Dactor, the Contributions of the patient to the Decision to Seek Medical Aid. In: Journal of chronic Diseases, Vol. 16, 1963, p. 975-989

Suchman, E.A., Heajth Oerientation and Medical Caxe. In: American Joumal of Public Health, 56, 1966, D. 97-105

Tagliacozzo, D.M. en K. Ima, Knowledge of I1lness as a Predictor of patient Behavior. In: Journal of Chronic diseases, Vol. 22, 1970, p. $765-775$

Teliegen, E., Medische Sociologie, en literatururwerkenning, Miphen aan den Rijn, 1970

Tittle, C.R., en R.J. Hill, Attitude measurement and the Prediction of Behavior: an Evaluation of Conditions and Measurement pechniques. In: Socilometry, 30, 1967, p. 199-213

Tolstorf, C.C., Social Networks, Support and Coping: An Exploratory study. In: Eamily process, 4, 1976, p. 407-417

Twadale. A.C., Health Decisions and Sick Role Variations: An Exploration. In: Journal of Health and social Behavior, $10,1969, \mathrm{p}, 105-115$

Twaddle, A.C., IIlness and Deviance. Irt: Soclal Sclence and Medicine, Vol. $7,1973$. P. $751-762$

Tijmstra, Tj., Sociologie en Tandhee 1kunde, diss., Groningen, 1980

Veen-Vietox, M. wan, Een plaatsje ondex de zon, doct. Fcr. "Rotterdam, 1975

Veen-Viätor, M. van, Mersen met psorjasis organiseren zich. In: BremerSchulte, M., red. "Samen beter worden, Alphen aan den Rija, 1900

Velden, E.G.M. van der, Huisvrouw - Wuisarts - Hujegezin, dise., NH jimegen, 1971 
Velden, H.G.M. wan der, Fubartsengenedsunde en medische opleiding. In: Mediscis Contact. $31,1976,2.1055-1060$

vexhack, P., Pexchische problenen in de husartspraktijk. In: Maandblad Geestelijke volksgezondheid, $1,1981,2.31-46$

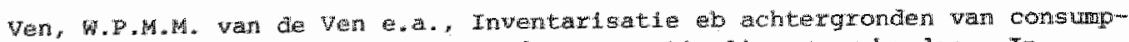
theverchilden tusen zikentonds-en paxticuliex verzekerden. In:

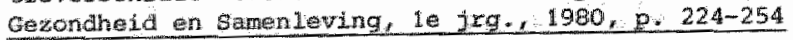

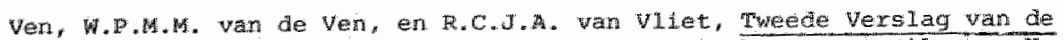

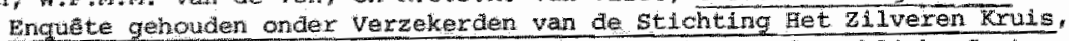
Notitie, Centrum voox onderzoek van de Economile wan de publieke sector, lelden, 1980

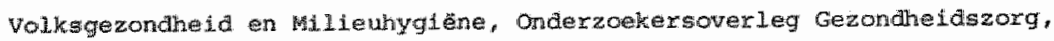

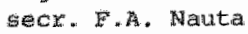

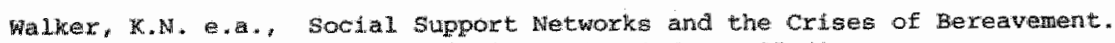
In: Social Sclence and wadictne, 11, 1977, $1.35-41$

Wike, H., an G.J. Kok, red. Socdale pgychologie in werandering, Alphen an den Rugh, 1978

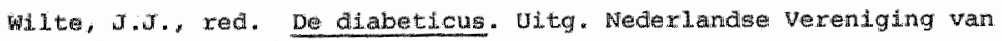
Sulkerckeken, den laag, a.n.

Zborowit. M., Cultural Components in Response to paln. In: Jaco.E.G. ed. Patients, Plyyicians and I. Iness, Glencoe, IIL. 1958

Zala, I.K., Iilness Behawtox of the horking class: Iraplications and Recommendions. In: Shostak, Aw. an w, Gonberg, eds. Blue Collat World, New Jersey, 1964.

Zola, I.K.. Culture and symptoms: An Analysis of patients Presienting complaints. In: Anerican Sociological Review, 31, 1966, p. 615-630

Zola I.K., In the Name of Health ard I1Iness, on some socio-politelcal Consequences of Medical Influence. In: Social Science and Mediolne, Vol. 9, 1975, P. $83-87$ 
B I J $L A G E N$ 


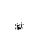


Bily lage 1 patiëntencategorleen en persoonskenwerken bigl paragraaf 4.2., aanvalling bij tabel 4.4 .

Tabel 1. Patientencategorieên naar opleiding

\begin{tabular}{lrrr} 
& & $s$ & \\
\cline { 2 - 4 } LO-VGLO & 10 & 11 & 0 \\
LENS-LTS & 4 & 5 & 4 \\
ULO-MAVO & 7 & 4 & 4 \\
VHMO-WNO-HAWO & 1 & 1 & 4 \\
MBO & 2 & 0 & 2 \\
HBO & 1 & 4 & 2 \\
WO & 0 & 0 & 1
\end{tabular}

een weg-vartantie-analyse: $F=0.78$ N.S.

Tabe1 2. patiêntencategorieen naar burgerlijke staat

Ongehuwd

Gehuwd

Weduwe/meduwnar.

Gescheiden

$\begin{array}{rrr}\text { H } & \text { s } & \text { P } \\ 1 & 3 & 0 \\ 23 & 19 & 23 \\ 1 & 2 & 1 \\ 0 & 1 & 1\end{array}$

$x^{2}=5.49$ N.S.

Tabel 3. Patientencategorieen naar urbanisatiegraad wan hun woonplaats

A

B

C $1,2,3$

C 4

c. 5

\begin{tabular}{llr} 
H & S & p \\
\hline 2 & 3 & 3 \\
8 & 8 & 12 \\
7 & 5 & 4 \\
2 & 4 & 2 \\
6 & 5 & 4
\end{tabular}

$$
\text { een weg-varantie-analyse: } F=0.64 \text { N.S. }
$$

Tabe1 4. patientencategorieën naar verzekeringsvorm

fonds

geen risico hulsarts

risico huisarts

excl. hudisurts

\begin{tabular}{rrr}
1 & 5 & 0 \\
\hline 19 & 19 & 15 \\
1 & 0 & 1 \\
3 & 4 & 4 \\
2 & 2 & 5
\end{tabular}

een weg-varlantie-analysie: $F=1.19 \quad$ N.S. 
Bllage 2. Opvattingen over de medische zorg en over ziekte: bepaling van de "aandoeningenathankelijkheid" "bil paragraaf 6.3.2.

Forriblexlag van opvattingen

1. J kunt weinich doen aun je elgen gezondheldstoestand

2. Het gebed is het beste geneesmiddel dat denkbaar is

3. Bijna elke zlekte heeft een paychische achtergrond

4. Zlikte is en straf op de zonde

5. Moderne geneesmiddelen zljn beter an ouderwetse midaltjes

6. De diepere oorzaak van veel ziekten $z 1 t$ in de maniex van leven

7. Tegenwoordig knnen artsen de meegte ziekten wel genezen

6. Zlekte ontstatin de meeste gevalien door spanningen

9. Doktoren beloven meer dan ze feltelijk kunnen doen.

10. Honlng is een geneesmiddel voor vele kwalen

11. In zilekte openbaart zich de strijd tussen goed en kwaad in de mens

12. Artsen weten ook niet altija wat goed voox if, is

13. De beste geneesmiddelen vind je in de natur.

14. Veel ziekten zijn een gevolg wam een losbandig leven

15. Je kunt beter te welnig geneesmiddelen innemen fan teveel

16. De naturix heeft geneesnidiellen voor elke ziekte

17. Als je max precies doet wat de doktex tegen je zegt, maak je de beste kans om beter te worden

13. Veel ziekten ontstaan omdat de mens te ver van de natuur afleeft

19. Verstandig lewen voorkomt veel zlekten

20. De natuur geneest zlchzelf

21. Axtsen schrijven te gemakkelijk allexlei medicijnen voor

22. Het beste geneesmiddel is een rein en opgewekt leven

23. Je krijgt lang nilet altijd het juiste advies van de doktex

1) wegens hoge partiele non-respons buiten de analyse gebleven 
255

Tabe1 1: Factoranalyse opwattingen en dumy m.b.t. hartinfaret (varimaxrotatie)

\begin{tabular}{|c|c|c|c|c|c|c|c|}
\hline Factor & 1 & 2 & 3 & 4 & 5 & 6 & 7 \\
\hline 1 . & 0.06 & 0.02 & 0.26 & 0.27 & 0.30 & 0.04 & 0.63 \\
\hline 2. & 0.16 & 0.33 & 0.10 & 0.09 & 0.17 & 0.65 & 0.28 \\
\hline 3. & 0.78 & -0.02 & -0.06 & 0.04 & 0.06 & -0.11 & -0.17 \\
\hline 糍. & -0.03 & 0.10 & -0.06 & 0.57 & -0.22 & 0.49 & 0.31 \\
\hline 6. & $0.51]$ & $0.4 \%$ & 0.34 & -0.03 & 0.17 & -0.04 & -0.13 \\
\hline $7 *$ & 0.37 & 0.013 & -0.07 & 0.13 & 0.69 & 0.09 & 0.04 \\
\hline 8. & 0.76 & 0.17 & 0.07 & 0.13 & 0.11 & 0.01 & 0.07 \\
\hline 9. & 0.23 & -0.11 & 0.79 & 0.09 & 0.20 & 0.05 & 0.01 \\
\hline 10. & 0.28 & 0.43 & -0.08 & 0.22 & 0.12 & -0.10 & 0.09 \\
\hline 11. & 0.15 & 0.12 & -0.06 & 0.80 & -0.13 & 0.00 & 0.10 \\
\hline 12. & -0.13 & 0.10 & 0.22 & -0.23 & 0.52 & 0.11 & -0.02 \\
\hline 14. & -0.05 & 0.16 & 0.15 & 0.72 & 0.33 & -0.10 & -0.13 \\
\hline 15. & -0.07 & 0.67 & 0.04 & 0.15 & 0.07 & -0.10 & -0.00 \\
\hline 17. & -0.16 & 0.26 & -0.37 & 0.16 & 0.50 & -0.24 & 0.38 \\
\hline 18. & 0.41 & 0.13 & 0.30 & 0,43 & -0.06 & 0.22 & -0.10 \\
\hline 19. & 0.25 & 0.64 & -0.12 & 0.04 & 0.05 & 0.23 & -0.07 \\
\hline 20 . & 0.67 & 0.21 & 0.21 & -0.05 & -0.24 & 0.17 & 0.23 \\
\hline 21. & 0.07 & 0.08 & 0.32 & 0.07 & 0.09 & 0.00 & $-0,63$ \\
\hline 22. & 0.14 & 0.81 & 0.18 & $0.0 \%$ & -0.02 & 0.07 & 0.10 \\
\hline 23. & -0.04 & 0.17 & 0.83 & 0.00 & 0.11 & -0.05 & -0.07 \\
\hline HART & & & & & & & \\
\hline \multirow[t]{3}{*}{ INAEARCT } & 0.17 & 0.31 & 0.07 & -0.03 & -0.09 & $=0.72$ & 0.38 \\
\hline & $\begin{array}{l}\text { OPV . } \\
\text { ZIEK }\end{array}$ & $\begin{array}{l}\text { OPV. } \\
\text { ZIEK- }\end{array}$ & $\begin{array}{l}\text { OPV. } \\
\text { ZORG }\end{array}$ & $\begin{array}{l}\text { OPV. } \\
\text { ZIEK- }\end{array}$ & $\begin{array}{l}\text { OPV. } \\
\text { ZORG }\end{array}$ & $\begin{array}{l}\text { HART- } \\
\text { TH- }\end{array}$ & $\begin{array}{l}\text { OPV. } \\
\text { ZTEKT }\end{array}$ \\
\hline & & & & & & $F$ & \\
\hline
\end{tabular}

Tabe 2 2: Factoxanalyse opvattingen en dumny m.b.t. diabetes (varimaxrotatie)

\begin{tabular}{|c|c|c|c|c|c|c|c|}
\hline Factor & 1 & 2 & 3 & 4 & 5 & 6 & 7 \\
\hline 1. & 0.03 & 0.27 & 0.23 & 0.02 & 0.42 & -0.06 & 0.55 \\
\hline 2. & 0.17 & 0.14 & 0.23 & 0.30 & 0.08 & 0.42 & 0.48 \\
\hline 3. & $\begin{array}{ll}0.78 \\
\end{array}$ & -0.04 & 0.00 & 0.00 & 0.06 & -0.11 & $=0.17$ \\
\hline 4. & -0.05 & -0.06 & 0.72 & 0.09 & -0.12 & 0.16 & 0.38 \\
\hline 6. & 0.51 & 0.35 & -0.08 & 0.46 & 0.11 & -0.01 & -0.09 \\
\hline 7. & 0.39 & 0.02 & 0.02 & 0.03 & 0.66 & 0.06 & 0.06 \\
\hline 8. & 0.76 & 0.08 & 0.13 & 0.17 & 0.13 & 0.03 & 0.06 \\
\hline 9. & 0.23 & {$[0.81]$} & 0.05 & -0.10 & 0.18 & 0.06 & 0.03 \\
\hline 10. & 0.26 & -0.07 & 0.14 & 0.46 & 0.23 & -0.20 & 0.01 \\
\hline 11. & 0.12 & $=0.07$ & 0.83 & 0.11 & 0.07 & -0.02 & 0.04 \\
\hline 12. & -0.10 & 0.23 & -0.28 & 0.08 & 0.40 & 0.40 & -0.03 \\
\hline 14. & -0.06 & 0.23 & 0.58 & 0.17 & 0.45 & -0.21 & -0.23 \\
\hline 15 & -0.08 & 0.05 & 0.09 & 0.69 & 0.11 & -0.14 & -0.08 \\
\hline 17. & -0.17 & -0.35 & 0.04 & 0.24 & 0.66 & -0.03 & 0.17 \\
\hline 18. & 0.41 & 0.30 & 0.49 & 0.13 & -0.05 & 0.19 & -0.09 \\
\hline 19. & 0.26 & -0.11 & 0.09 & 0.63 & 0.01 & 0.19 & 0.03 \\
\hline 20. & 0.66 & 0.18 & 0.06 & 0.21 & $=0.25$ & -0.01 & 0,32 \\
\hline 24. & 0.11 & 0.34 & 0.03 & 0.08 & -0.03 & 0.26 & -0.62 \\
\hline 22 . & 0.12 & 0.16 & 0.07 & {$[0.80]$} & -0.01 & 0.07 & 0.13 \\
\hline $2 \pi$. & -0.05 & 0.82 & -0.02 & 0.18 & -0.18 & -0.09 & -0.04 \\
\hline \multirow[t]{2}{*}{ DIABETES } & -0.07 & -0.09 & 0.08 & -0.09 & -0.02 & 0.86 & -0.12 \\
\hline & $\begin{array}{l}\text { OPV } \\
\text { ZIEKTE }\end{array}$ & $\begin{array}{l}\text { OPV. } \\
\text { ZORG }\end{array}$ & $\begin{array}{l}\text { OPV. } \\
\text { ZIEKTE }\end{array}$ & $\begin{array}{l}\text { OPV. } \\
\text { ZLEKTIE }\end{array}$ & $\begin{array}{l}\text { OPV. } \\
\text { ZORG }\end{array}$ & DHABETES & $\begin{array}{l}\text { OPV. } \\
\text { ZTEKT }\end{array}$ \\
\hline
\end{tabular}




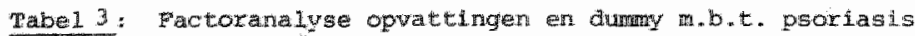
(variflatarotatie)

\begin{tabular}{|c|c|c|c|c|c|c|c|}
\hline Factor & $\mathbb{1}$ & 2 & 3 & 4 & 5 & 6 & 7 \\
\hline 1. & -0.02 & 0.14 & 0.01 & 0.20 & 0.43 & 0.54 & 0.13 \\
\hline 2. & 0.27 & 0.12 & 0.14 & 0.15 & 0.06 & 0.66 & -0.07 \\
\hline 3. & 0.04 & -0.02 & 0.7 제 & 0.01 & 0.10 & -0.18 & -0.09 \\
\hline 4. & 0.08 & -0.09 & $-0,07$ & 0.67 & -0.10 & 0.46 & -0.12 \\
\hline 6. & 0.44 & 0.37 & 0.50 & -0.09 & 0.13 & -0.01 & 0.01 \\
\hline 7. & 0.08 & -0.01 & 0.36 & -0.07 & 0.69 & 0.15 & -0.12 \\
\hline$B$. & 0.15 & 0.00 & 0.75 & 0.14 & 0.13 & 0.10 & 0.12 \\
\hline 9. & -0.11 & 0.79 & 0.22 & 0.02 & 0.18 & 0.16 & 0.01 \\
\hline 10. & 0.45 & -0.10 & 0.26 & 0.17 & 0.24 & -0.04 & 0.06 \\
\hline 11. & 0.10 & -0.06 & 0.11 & 0.85 & 0.09 & 0.07 & 0.08 \\
\hline 12. & 0.01 & 0.20 & -0.11 & -0.25 & 0.31 & 0.07 & 0.30 \\
\hline 14. & 0.23 & 0.22 & -0.08 & 0.53 & 0.53 & -0.15 & -0.22 \\
\hline 15. & 0.71 & 0.05 & -0.08 & 9.06 & 0.12 & -0.04 & -0.05 \\
\hline 17. & 0.21 & -0.40 & -0.18 & 0.05 & 0.57 & 0.11 & 0.37 \\
\hline 18. & 0.10 & 0.36 & 0.40 & 0.51 & -0.03 & 0.06 & 0.08 \\
\hline 19. & 0.63 & -0.06 & 0.25 & 0.07 & -0.02 & 0.11 & 0.05 \\
\hline 20 . & 0.17 & 0.15 & 0.65 & 0.07 & -0.24 & $0.3^{A}$ & 0.02 \\
\hline 21. & 0.07 & 0.40 & 0.11 & 0.07 & -0.03 & -0.47 & 0.11 \\
\hline 22. & 0.78 & 0.16 & 0.11 & 0.05 & -0.04 & 0.21 & 0.16 \\
\hline 23. & 0.17 & 0.90 & -0.06 & -0.03 & -0.13 & 0.05 & -0.09 \\
\hline \multicolumn{8}{|c|}{ PSORIA- } \\
\hline \multirow[t]{2}{*}{ SIS } & -0.11 & 0.04 & -0.08 & -0.05 & 0.07 & 0.05 & -0.90 \\
\hline & $\begin{array}{l}\text { OPV. } \\
\text { ZIEKTEE }\end{array}$ & $\begin{array}{l}\text { OPV. } \\
\text { ZORRG: }\end{array}$ & $\begin{array}{l}\text { OPV. } \\
\text { ZIEKTE }\end{array}$ & $\begin{array}{l}\text { OPV: } \\
\text { ZIEKTE }\end{array}$ & $\begin{array}{l}\text { OPV. } \\
\text { ZORG }\end{array}$ & $\begin{array}{l}\text { OPV. } \\
\text { ZIEKTEE }\end{array}$ & ASIS \\
\hline
\end{tabular}


Billage 3: Attituden t.a.w eiger arts: bepaling van de "aandoeningsarhankelijkheic" bil paragraf 6.3 .3 .1

Pornulering van uitespraken

1. Mijn (huis) arts is nogal onzeker in zijn optreden

2. Mijn (huis)arts staat erop, dat je precles doet wat hil zegt

3. Mijh (huis)arts vertelt precies hoe ernstig het is

4. Mijn (huis)arts stelt je op je gemak als je met hen prat

5. Mijn (huis) arts is nogad zakelijk

6. Mijn (huis) arts schrijft je nauwkeurig voor wat je moet doen

7. Mijn (huis)arts praat met me over andere dingen dan over mijn ziekte alleen

a. Mijn (muis)arts legt me uit warom hij jets op een bepalda manier doet

9. Mijn (huis) arts behandelt me als numer

10. Mijn (huis)arts prat met me over andere dingen an medische problemen

11. Mijn (huis) arts heett weinig tija voor me als ik hern raadpleeg

12. Mijn (huisliarts is bereid om naar je moeilijkheden te iuisteren

Tabe 1 1: Factoranalyse, attituden en dumm m.b.t. hartinfarct

\begin{tabular}{|c|c|c|c|c|c|}
\hline Factor & 1 & 2 & 3 & 4 & 5 \\
\hline 1. & 0.03 & -0.04 & -0.15 & 0.13 & 0.85 \\
\hline 2. & 0.03 & 0.04 & 0.12 & 0.77 & 0.22 \\
\hline 3. & 0.06 & 0.62 & 0.10 & 0.40 & -0.15 \\
\hline 4. & 0.74 & 0.30 & -0.06 & 0.18 & -0.16 \\
\hline 5. & -0.33 & -0.03 & 0.58 & -0.08 & 0.60 \\
\hline 6. & 0.10 & 0.17 & -0.15 & 0.80 & -0.08 \\
\hline 7. & 0.27 & 0.84 & -0.22 & -0.06 & 0.09 \\
\hline 8. & 0.00 & 0.72 & 0.19 & 0.20 & -0.19 \\
\hline 9. & -0.81 & -0.26 & 0.10 & -0.14 & 0.10 \\
\hline 10. & 0.35 & 0.78 & -0.05 & 0.00 & 0.15 \\
\hline 11. & -0.82 & -0.14 & 0.01 & 0.10 & -0.14 \\
\hline 12. & Lo.80 & -0.01 & 0.03 & 0.02 & -0.03 \\
\hline $\begin{array}{l}\text { HART'- } \\
\text { INEARCT }\end{array}$ & & & & & -0.14 \\
\hline INERRCI & 0.03 & 0.03 & $\frac{0.92}{\mathrm{HART}}$ & 0.02 & -0.14 \\
\hline & & & INIEARCT & & \\
\hline
\end{tabular}

1) Zile ook bijlage 12 


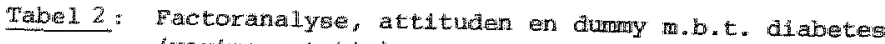
(varimaxrotatie)

$\begin{array}{lccccc}\text { Factor } & 1 & 2 & 3 & 4 & 5 \\ 1 . & 0.09 & -0.06 & 0.11 & {[0.79]} & -0.05 \\ 2 . & 0.02 & 0.06 & {[0.75} & 0.27 & 0.31 \\ 3 . & 0.03 & {[0.62} & 0.43 & -0.14 & -0.09 \\ 4 . & {[0.74} & 0.29 & 0.19 & -0.17 & -0.09 \\ 5 . & -0.40 & 0.01 & -0.09 & {[0.70]} & -0.12 \\ 6 . & 0.13 & 0.12 & {[0.80} & -0.09 & -0.15 \\ 7 . & 0.31 & 0.84 & -0.05 & 0.02 & 0.18 \\ 8 . & -0.03 & {[0.70]} & 0.23 & -0.16 & -0.40 \\ 9 . & -0.81 & -0.25 & -0.15 & 0.13 & 0.05 \\ 10 . & 0.36 & 0.79] & 0.00 & 0.12 & 0.15 \\ 11 . & -0.82 & -0.13 & 0.09 & -0.11 & 0.18 \\ 12 . & {[0.77} & 0.01 & 0.01 & -0.03 & 0.13 \\ \text { DIABETES } & -0.09 & 0.04 & 0.04 & -0.16 & 0.88 \\ & & & & & \text { DIABETES }\end{array}$

Tabe1 3: Factoranalye, attituden en dumy m.b.t. psociasis (varimaxrotatie)

\begin{tabular}{|c|c|c|c|c|c|}
\hline Factor & 1 & 2 & 3 & 4 & 5 \\
\hline 1. & 0.05 & -0.05 & 0.15 & 0.78 & 0.39 \\
\hline 2. & 0.00 & 0.04 & 0.75 & 0.26 & -0.33 \\
\hline 3. & 0.04 & 0.65 & 0.38 & -0.11 & -0.11 \\
\hline 4. & 0.73 & 0.29 & 0.18 & -0.19 & 0.08 \\
\hline 5. & -0.33 & -0.02 & -0.09 & 0.72 & -0.29 \\
\hline 6. & 0.07 & 0.20 & 0.79 & -0.13 & 0.23 \\
\hline 7. & 0.34 & 0.80 & -0.09 & 0.05 & 0.03 \\
\hline 8. & -0.05 & 0.76 & 0.18 & -0.14 & 0.07 \\
\hline 9. & -0.80 & $=0.25$ & -0.14 & 0.15 & -0.09 \\
\hline 10. & 0.41 & 0.75 & -0.02 & 0.14 & -0.08 \\
\hline 11. & -0.80 & -0.13 & 0.08 & -0.09 & -0.19 \\
\hline 12. & {$[0,80]$} & -0.03 & 0.02 & -0.05 & -0.16 \\
\hline PSOR & 0.07 & -0.03 & -0.03 & 0.05 & 0.90 \\
\hline
\end{tabular}


Bijlage 4: Variabelen ter bepaling wan de "ziektebelewng" buj pat. 6.3.5.

1. KWALITATIEUE BEPALING Q.G.W.

A. Leefregels

Moet u op advies van de dokter i.v.m.

HART INEARCT :

1. zoutloos of zoutarm eten

2. stoppen met raken, verminderen

3. weel wandelen

5. vermageren

B. Klachten

Hebt of wel eens last van
HARTINEARCT

1. pijn op de borst (= angina pectoris)

2. hartkloppingen

3. benauwdheid, kortadenigheid

4. pijn in linker arm, nek of rug

5. andere klachten i.v.m. het hartinfarct, t.w.
DIAEEPTES:

1. diset houden (excl. vermageren)

2. mealcijnen slikken

3. injekties gebruiken

4. vermageren

5. zelf Uw urine kontroleren
PSORIASTS:

1. zalf gebruiken

2. medici jnen gebrutken

3. hoogtezon gebruiken

4. var cen zonnebank gebruskmaken

\section{DTABETE:S}

1. hongerig gevoel

2. dorst

3. infekties

4. hypo's

5. hyper's

6. andere kidachten 1.w.th. diabetes, t.w.

\section{PSORIASIS}

1. verel schilfers

2. plekken die ineens zichtbaar worden

3. andere klachten i.v.m. psorlasis, t.w.

\section{"voorts: :}

4. komt het waak woor dat de psoriasis erger is dan ancers?

5. hebt 0 psoriasis

- alleen op het hoofd

- alleen aar de ledenaten

- alleen op de romp

- op hoofd en ledematen

- op ledematen en romp

- op hoofd, ledematen en romp

- weet niet

- geen antwoord 


\section{c. Beleymering hinder}

Inlatiende zin:

De meeste mensen habben vooral last van cen aandoening als ze mexken dat ze bepalide aingen moelijjker of helemal niet kunnen doen.

\section{Gartinfarctpatienter}

1. Belemering bij huishoudelijk werk zoals stofzuigen, afwassen e.a. (strek, een beetje, geen belemering; voorzover van toepassing)

2. Hinder op feestjes door hartinfarct (sterk, een beetje, geen hinder; voorzover van toepassing)

3. Wordt $\mathrm{u}$ bij het traplopen gehinderd door het feit dat $\mathrm{U}$ een haxtinfarct gehac hebt?

(sterk, een beet je, helemaal niet gehinderd)

4. Zijn ex andere aktiviteiten waarbil $u$ gehinderd wordt door het felt dat $U$ een hartinfaxct gehad hebt? zo ja, welke?

Diabetici

11 Hinder door guikerziekte a ls respondent gaat eten? (sterk, een betje, helenaal nitet gehlnderd; voorzover van toepassingy

2. Hinder op frestjes door diabetes (sterk, een beetje, geen hinder; voorzover van toepassing)

3 . Hindex op vakantie aoor diabetes (stexk, cen beetje, nilet gehinderd; voorzover van toepassing)

4. Zijn ex andere aktiviteiten warbiy o gehindexd wordt daor het feit dat U suikerzlekte hebt? zo ja, walke?

Psoriasis

Hinder (sterk, een beetje, geen hinder) bij

1. de eigen vexzorging, hygleme

2. kontakten met vxienden

3. kontakten met officielle instanties, met wreemden

4. hinder bij zwermen in een openbare zweminxichting of in zee (sterk, een beetje, geen hinder; voorzover van toepassing)

5. zijn er andere aktiviteiten warbij u gehinderd wordt door het feit dat u psoriasis hebt? zo ja, welke? 
2. KWANTITAMIEVE BEPALIMG

Correlaties (rho"s) "ziektebeleving", totaal en per patientencategorie

1. frequentie zich ongerust maken over aandoenjing

2. mate warin lieven anders is dan dat van anderen

3. wate warin geleerd om met: aandoening te leven

\begin{tabular}{llllll} 
& 2. & 3 & 4. & 5 \\
\hline $\mathrm{T}$ & {$[.44$} & -.17 & {$[-.37$} & -.17 \\
$\mathrm{~F}$ & {$[.66$} & -.23 & -.60 & -.36 \\
$\mathrm{~S}$ & .10 & -.15 & .01 & .09 \\
$\mathrm{P}$ & {$[.40$} & -.22 & -.34 & -.25
\end{tabular}

4. mate warin zjek of gezona met aandoening

$\begin{array}{lrrr}\mathrm{T} & -.24 & -.38 & -.15 \\ \mathrm{H} & -.39 & -. .83 & -.56 \\ \mathrm{~S} & -.11 & -.07 & .14 \\ \mathrm{P} & -.23 & -.05 & .01 \\ \mathrm{~T} & & -.37 & -.40 \\ \mathrm{H} & & .49 & .32 \\ \mathrm{~S} & & .50 & .35 \\ \mathrm{P} & & .25 & .53 \\ \mathrm{~T} & & & {[.37} \\ \mathrm{H} & & & . .52 \\ \mathrm{~S} & & & .18 \\ \mathrm{~F} & & & . .44\end{array}$

5. Erequentie warmee last van aandoening t.g.v. spannning

$\mathrm{T}=$ totaal $(\mathrm{M}=75)$

$H=$ hartinfarctpatiënten $(N=25)$

$\mathrm{s}=$ suikerpatiënten $(\mathbb{N} \quad 25)$

$\mathrm{P}=$ psoriasispatiënten $(\mathrm{N}=25)$

gelet is op

- significantie van de totale groep

- richting van de verbanden pex patienten ategorie

- voorzover mogelijk de significantie per patientencategorie

3. CORRELATIES van (1) en (2) met de schaalwaarde "zlektebeleving" (slecht goed (rho's, allen gignificant bif $p \leq .002$ )

1. kwalitatieve bepaling (slecht * goed) 80

2.1. frequentie zich ongerust maken (noolt - waak) .59

2.2. Lever anders met andoening (arg sterk thelemal. niety .51

2.3. geleerd met aandoening te lever (helemali niet * voliedig) .33

2.4. ik ben gezond/ziek met.... (zlek * gezond) .48.

2.5. last t.g.v. spamingen (vaak $\rightarrow$ noolt) . .39 
Eljlage 5: Factoranalyse gedragsintentie bij paxagraaf 6.3.6.

Principale component, orgeroteerde structura

1. U hebt inds eer week en jemkende uitsiag

2. U hebt een midag lang sterke pijn in de buik

3. U ontolet op een kear bloed bij de ontiasting

4. U habt ineens last van harthloppingen

5. U nebt ands een week gebrek an etilust

6. U hebt on en ochtend $3 e^{\text {k koorts }}$

7. U hebt vier dagen aneen sterke dorst

๑. U bent 1 drie aagen verkouden en nebt keelpijn

9. U hebt ean dag of vier lang hoofdpijn

10. U hebt op eer ochtend eczeen op de armen

11. U hebt op erm dag ineens Last van kortadenigheid en berawheid

12. U mot sinds dxie dagen waker plassen dan U normal acht

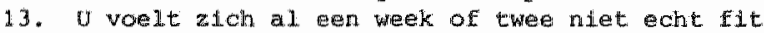

14. U voelt al eer dag of twee plin in de rug

\begin{tabular}{|c|c|c|c|c|c|}
\hline Tactor & 1 & 2 & 3 & 4 & 5 \\
\hline 1. & 0.50 & 0.30 & 0.19 & 0.41 & -0.45 \\
\hline 2. & 0.48 & 0.08 & 0.49 & 0.17 & 0.15 \\
\hline 3. & 0.53 & 0.53 & 0.06 & -0.25 & -0.19 \\
\hline 4. & 0.48 & 0.36 & -0.01 & -0.30 & 0.39 \\
\hline 5. & 0.51 & -0.20 & 0.41 & 0.35 & 0.29 \\
\hline 6. & 0.52 & -0.12 & 0.23 & -0.39 & 0.14 \\
\hline 7. & 0.51 & -0.32 & -0.10 & 0.17 & -0.16 \\
\hline 8. & 0.57 & -0.5 .5 & 0.20 & -0.21 & -0.18 \\
\hline 9 & 0.58 & $-0 \times 54$ & -0.04 & -0.31 & -0.18 \\
\hline 10 & 0.50 & 0.0 .4 & -0.25 & 0.35 & -0.45 \\
\hline 11. & 0.55 & 0.46 & 0.15 & -0.31 & -0.11 \\
\hline 12. & 0.51 & 0.07 & -0.65 & 0.03 & 0.12 \\
\hline $13 \ldots$ & 0.56 & 0.00 & -0.12 & 0.47 & 0.52 \\
\hline 14. & 0.52 & -0.016 & -0.55 & -0.10 & 0.13 \\
\hline$r^{2}$ & 27.6 & $10 ., 7$ & 9.8 & 0.9 & 8.1 \\
\hline $\begin{array}{l}\text { EIGEW- } \\
\text { WAARDE }\end{array}$ & 3.86 & 1.49 & 1.37 & 1.24 & $1 * 13$ \\
\hline
\end{tabular}


Biflage 6: Samerhangen tussen het antal huisartscontacten consungitiegeneigaheid apart voor de drte patientencategoriesn, gecontroleerd voor controlenoodzalk (Kendall's rangoortelaties, gepaztialiseerd) bij paragraaf 7,3 .

\begin{tabular}{|c|c|c|c|c|c|}
\hline & $\begin{array}{l}\text { vertr. zorg } \\
\text { veel weinig }\end{array}$ & $\begin{array}{l}\text { att.arts } \\
\text { pos + reg. }\end{array}$ & $\begin{array}{l}\text { Opy -zi ekte } \\
\text { onpr } \rightarrow \text { prot. }\end{array}$ & $\begin{array}{l}\text { ziekteble } 1 . \\
\text { slecht } \rightarrow \text { goed }\end{array}$ & $\begin{array}{l}\text { gedragsint. } \\
\text { sterk-gerting }\end{array}$ \\
\hline hartinfarct & -.21 & -.23 & .10 & -.12 & -.23 \\
\hline dilabetici & -.07 & -.37 & .06 & -.12 & -.06 \\
\hline psoriasis & -.24 & -.18 & .09 & -.05 & -.12 \\
\hline
\end{tabular}

Bij de interpretatie van deze tabel moet bedacht worden, dat bij een relatief klein aantal warnemingen per groep de rangcorrelaties nogal sterk kunnen verschillen. Belangrijker dan de absolute warde van deze carrelaties is daarom in eerste instantie de richting exvan. Deze komt voor alie wijfien uitkonsten overeen met de uitkcrasten voor de totale steekproef.

Ex zijn drie in het oog spxingende verschilpurten. Twee ervan betreffen de diabetici. Bij hen zijn de correlaties tussen gedragsintentie resp. vertrouwer in de medische zorg en het antal hulsartscontacten relatief laag vergeleken met die van de andere twee groepen. Daar staat echter een relatief hoge samenhang tussen de attitude ten aanzien van de arts en medische consumptie tegenover. Het derde vexschilpunt betreft de relatief geringe samenhang tussen ziektebeleving en medsche consumpte van psoriasispatienten. Dit wijst vermoedelijik op een nogal rationeel besissingsproces van deze patienten, als zij hun hulsarts willen consulteren, dat. vooxal wordt beInvloed door het vertrowwen, dat alj in de medische zorg: stellen en minder door emotionele Invioeden (zie ook hoofdstuk 14 paragraaf 1). 
Bdjlage 7 hatrix vain product-moment correlatie-coefficienten bil pax. $7.3 ., 11.4 ., 12,14.1$, en 14.2 .

1. rataleger Musarts

2. controlenoodzath

3. 21ektebeleving patient

4. attutude arts patient

5. gedragsintentito patient

6. vertrowwen in inedische zorg patid

7. aekteopwattingen patient

8. 2t retheleving de adviseur

9. attitude axt 1 ie advigeur

10. gedrggimtentie le adviseur

11. vertrowen in medische zorg le adviseur

12. ziekteopwattingen 1 advisieve

13 ziektebeleving 2 e adriseur

14. attitude arts $2 \mathrm{e}$ adviseur

15. gearagintentle 2 e adviseur

16. vertrouwer in medische zorg $2 e$ adviseur

17. ziekteopvattingen 2 advisenr

18. ameal advigems genoend

19. Wate van genelgaheid in netwerk

20. Dordeel over zlekte van le adviseux

21. omwang lekennetwerk

22. gebruik vee1 woorzieningen

23. xadplegen alternatieve genezers

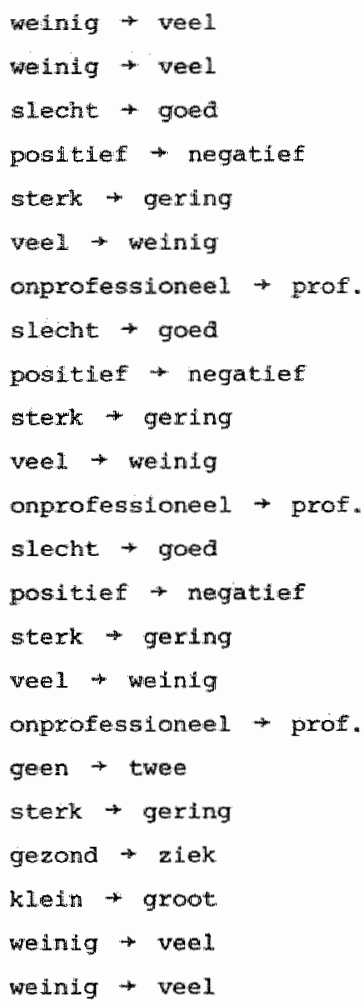




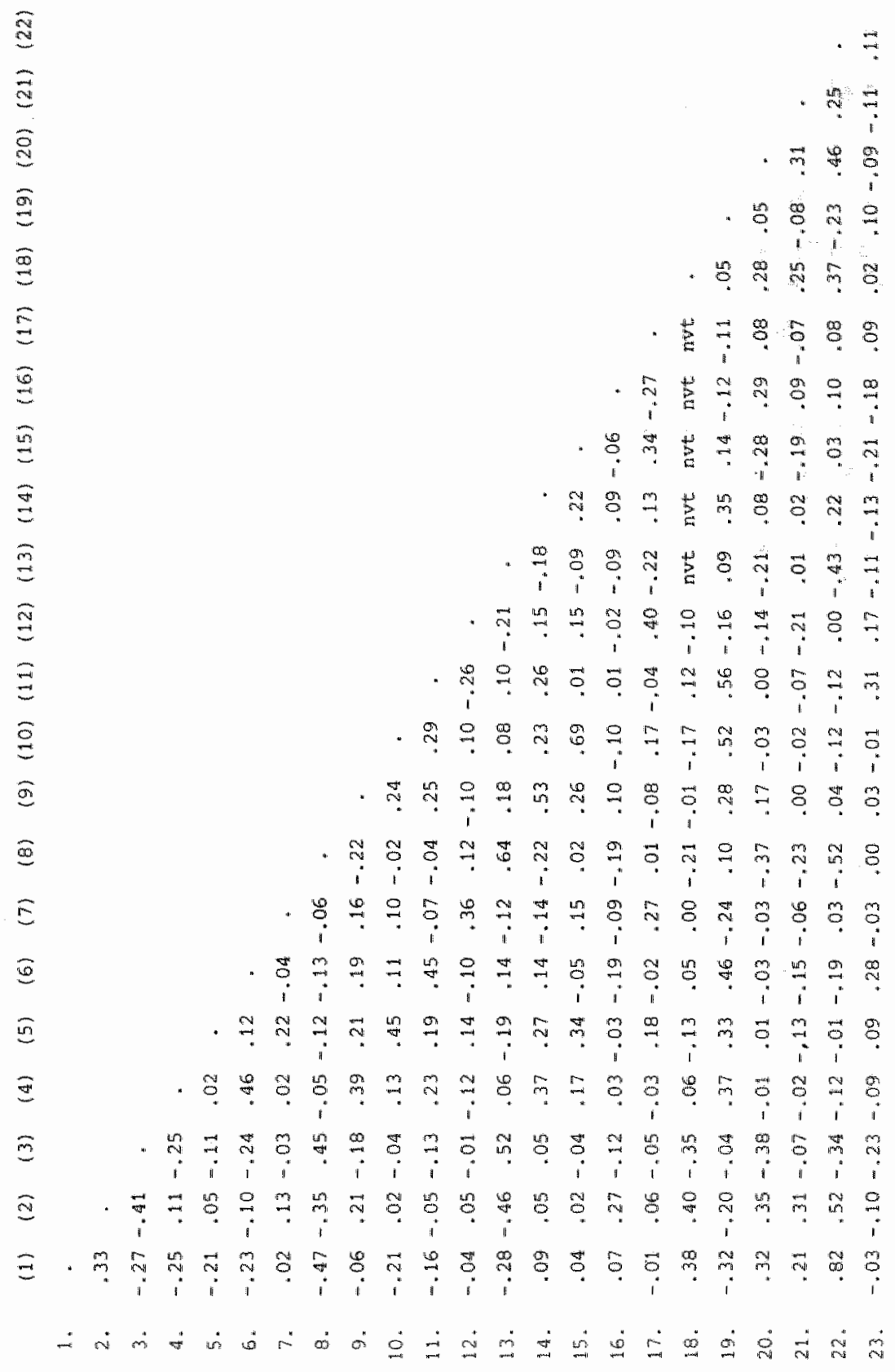


Bijlage 8: Hatxu van product-moment correlaties tussen huisartscontacten en consumptiegerelgaheid woor patient-respondenten. dife In verband met de adadoening in kwestie naax de husarts gingen $(w=59)$ bij paragraat 7.3 .
(1)
(2)
(3)
(4)
(5)
(6)

raaplegen huisarts

(1) vee 1 - vee 1

(2) zLek tebelewing

$-.27$.

slewt $\rightarrow$ goed

(3) attituce t.a. v. arts possitief $\rightarrow$ regatief

$$
-.31-.20
$$

gedragisintentie

$-.35-.12-.13 \quad$.

sterk $\rightarrow$ gexing

(5) ziekte-opvateingen

$$
\begin{array}{rrrr}
-.04 & -.09 \quad .16 \quad .17
\end{array}
$$

onprof. $\rightarrow$ prof:

(6) vectrouwen in zorg

$\begin{array}{llll}-.14 & -.24 & .54 & .22\end{array}$

.08

vee $\rightarrow$ welnig

(7) controlenoodzatk

$-.27-.40$

.15

.02

$.08 \quad-.09$ 
Bl 1lage 9: Operationaliseringen wan medische kennis en stress blj paragraat 7.5.

1. Medische kennis

Wi I hebben de medische kennis tan ellke paticntengroep arzonderlljk gemeten door middel van elk tien pragen, di op a andoeningen betrekking hadcen. De respondenten konden zeggen, of een bepaalde uitsprak wolgens hun juist of onjuist was. Ook het antwoord "ik zou het niet weten" was expliciet toegestaan. De hoveelheid kennis werd echter ge indiceerd door de som van net aantal goede antwoorden. I)

Deze werkwijze heeft het nadeel, dat het niveau van medische kennis van de drie patientengroepen niet airect vergelijkbaar is.

De vragen kunren immexs per patientencategoxie in moelifjkheidsgrad werschillen. Tabel bijlage 9,1 geeft de vragen en antwoorden per patentengroep weer. Daarult blijkt een tweede bezwart somige vragen zijn onbecioela "strikvragen" geworden; zij waren zo moeilijk, ata slechts enkelen daarop het juiste antwoord wisten. On medische kennis toch als een variabela voor alle respondenten te kunen gebruiken, hebben wil per patidntencategorie gestandacalseerde scores bexekend. Daarbij gaan wij uit van de veronder stelling, dat het gemiddelde kennisniveau van de dxie groepen en de varianLie daarbinnen niet verschillen.

De berekeningen Iuiden voor:

kemnisicore - 5.49

haxtinfarctpatienten

1. 53

kennisscore -5.24

diabetici

2.07

kennisscon -7.28

psoriasispatienten

1.65

Wil betrekken dus niet het absolute kennisniveau in de beschowing mar de mate warin de individuen van het geniddelde hennisniveau afwijken.

11) on verwarring bij de respondenten te voorkomen is hen na afloop van het gesprek een overzicht met juiste en onjulste uitspraken overthandigd. 
Tabel 1: Utspraken over medische zaken en de reacties van respondenten darap, naar patientencategorie.

\section{Hart in arctepatidnter}

Buj dikke mensen tot het hare harder werken dan bij jagexe

eliproken is gevadrliker an sigateten roken

Alcoholgebrulk verlagt het cholestrolgohlate in het blaed

trombose kan met antistollings-

middelen wardien voorkomen.

Garnalen bevatten weinig cholestrol

zoetigheden bevatten weel cholestral

Je kunt verhoogde bloeddruk hebben

zonder het te merken

Magere mensen kunnen geen verhoogd

cholestrolgehalte in het bloed mebber

Lever bevat veel cholestrol

Drop eten verhoogt de bloeddruk

Suikerpatidenten

Ex zijn verschillende soorten diabetes

Peulvychten bevatten veal eikitten

Sulkerziekte is een ziekte van het bloed

Gezonde voeding moet vlees, vis of $\mathrm{kip}$ bevaten

Diabetici heblon soms extra last wan huidinfecties

Bij zwangerschap kan diabetes an het Jitht treden

Diabetes komt vooral bij jonge mensen voor

Je gebrulkt de juiste voeding als je

gew id cht goed is

biabetol moeten hua voeten extro grod verzorgen

Verge greenten zijo gezonder dan

diopuriesgoenten

\begin{tabular}{|c|c|c|}
\hline 15 & $\begin{array}{c}\text { genoema } \\
\text { doox }\end{array}$ & $\begin{array}{l}\text { neet } \\
\text { nLet }\end{array}$ \\
\hline (Juist) & 20 & 3 \\
\hline (Onjulst) & 18 & 6 \\
\hline (Onjuist) & 10 & 10 \\
\hline (avist) & 18 & 7 \\
\hline (Onjuset) & 4 & 19 \\
\hline$(o n j u: s t)$ & 1 & 10 \\
\hline (Juist) & 15 & 3 \\
\hline (Onju且st) & 19 & 3 \\
\hline (Jus & 12 & $\dot{\theta}$ \\
\hline$(J u d g t)$ & 20 & 4 \\
\hline (Juist) & 20 & 4 \\
\hline (Jüst) & 15 & 9 \\
\hline tonjuist) & 12 & 4 \\
\hline (Onjuist) & 5 & 3 \\
\hline 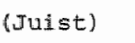 & 14 & 7 \\
\hline (wuist) & 18 & 7 \\
\hline (Onjuist) & 21 & 4 \\
\hline (onjuisto) & 10 & 7 \\
\hline$(\mathrm{Juist})$ & 13 & 8 \\
\hline (onjuist) & 3 & 1 \\
\hline
\end{tabular}




\section{por iessidspatienten}

Esomas werloopt meestal in lagen, dan wer ex gir dan wer beter

Esorists kont wooral woor in het geralcht

Psoxiasis is een infektie van de hud

Wet poriasis mag je niet zwemmen

De precieze oorzak van psoriass

is niet bekend

Roriasis verloopt bij welhaast

a.le memsen gelljk

Het meest gebruikte midal tegen

psoriasis is penicilline

Psoriasis is besmettelijk

Buitenlucht heeft meestal een gunstige invived op het verloop van psoriasis

\begin{tabular}{|c|c|c|}
\hline is & $\begin{array}{c}\text { gemonena } \\
\text { door } \\
\end{array}$ & $\begin{array}{l}\text { "weet } \\
\text { nuts }\end{array}$ \\
\hline$(\pi) 2 s t)$ & 22 & 1 \\
\hline (onjuist) & 22 & 3 \\
\hline (onjuist) & 8 & 11 \\
\hline (onjuliss) & 21 & 2 \\
\hline (Juist) & 18 & 4 \\
\hline (onjuist) & 13 & 11 \\
\hline (onjuist) & 17 & 8 \\
\hline$(0 n j u i s(t)$ & 25 & 0 \\
\hline (Juist) & 19 & 5 \\
\hline (unist) & 17 & $d$ \\
\hline
\end{tabular}

Psoriagis kan exflijk zijn

hutst

\section{Stress: Vragenlijst onderzoek Ervaren Gezonaheidstoestand}

Voor het indiceren van "stress" makten wij gebruith van en V.O.E.G.versie, die aan de Rijksuniversiteft van Linburg is ontwikkelid, zij bevat

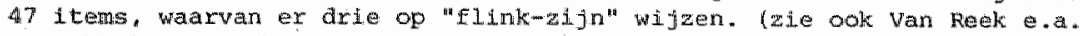
te publ.). Wij gebruikten een eenvoudige, gesonmerde shall met de volgendie statistische kemmerken. 1 )

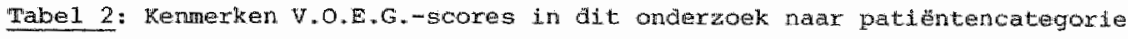

\begin{tabular}{|c|c|c|c|c|}
\hline & gem. score & mediaan & st. diev. & bereik \\
\hline total & 12.48 & 10.7 & 7.20 & $2-30$ \\
\hline$\pi$ & 14.04 & 14.0 & 0.05 & $3-30$ \\
\hline$s$ & 13.20 & 12.0 & 6.24 & $3-27$ \\
\hline$p$ & 10.20 & 8.2 & 6.89 & $2-24$ \\
\hline
\end{tabular}

1) Bet is ook mogellilk om met behulp van deze vagentiogt werschillende dimencises te onderscheiden die bepalde klachterpationen samenvatten. ondat niet duidelijk is, in welke mate wich bij deze chrontsche

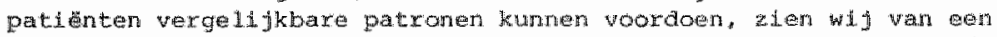
nadere specticering op dit punt at. Blj de sommerng blevan de dite "Flinkhedaltemes buiten beschow ing. 
Biflage 20: Attituden yar lekenadviseurs t.a.t. de aandoening wan de patient; bif paragalf 10.1

Variablen:

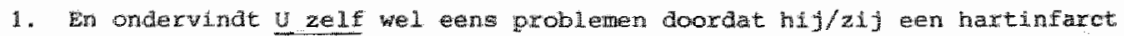
gehad heeft? $z$ it 0 er bifw. wel eens ovex te plekexen of over na te denken? Doet o dat vaak, sons, zeliden of nooit? (hmaloog voor liekenadviseurs var diabetic1 en psoriasispatiërten).

2. Als $U$ heel eerlijk bent poor $U$ zelf, vinat $U$ het dan wel eens lastig det ... keen hartinfarct gehad heeft? Bijw. chalat hij/zij veel beroep op u doet? of om een andere reden? (Amaloog voor lekenadviseurs vam diabeticl en psorlasispatienten.

3. Maakt 0 zich wel cens ongerust over ... "laandoening? Doet 0 dat vaak, zo nu en dan, zellen of nooit?

1) naam var patient-respondent

Tabe 1. 1: Correlaties "zlektebelevingsvariabelen" eerste lekenadviseux (rho"s, onikaderd biy significantieniveau van $p<.03$ )

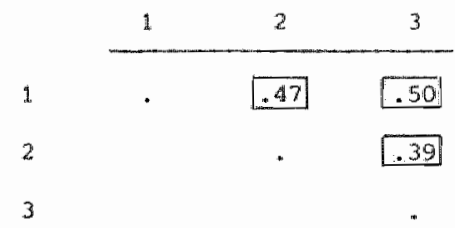

"abel 2: Correlaties "ziektebelevingsvariabe lem" tweede lekenadviseur

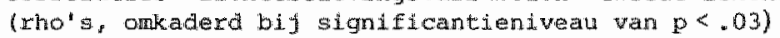

\begin{tabular}{|c|c|c|}
\hline & 1 & 2 \\
\hline 1 & - & 0.30 \\
\hline 2 & & . \\
\hline & & \\
\hline
\end{tabular}


Bijlage 11: Bepaling wan homogene en heterogene netwexken achtergronden van praktische hulp en enotionele stewn in netwerken bil paragraas 10.4. An hoofdstuk. 11

1. Bepaling van de mate van homogeniteit in netwerkent

On homogene en heterogene netwerken to identificeren werd de volgende procedure toegepast. De vifitien geneigdheldsconponenten van de patidnt

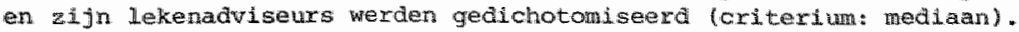
Per geneigaheidscomponent werd de mate van overeensteming bepanda:

(1) tussen patizint en eexste lekenadviseur

beidie eens, sterk geneigd = homogeen stork

beide eens, geringe geneigdheid = homogeen gering

oneers = heterogeen

(2) tussen alle netwerkleden

allen eens en overeenstemulng tussen patient en alleen ijn exste adviseur, sterk genelgd = homogeen sterk

idem, geringe genelgdhezd = homogeen gering

all lie tussenvormen = heterogeen

Ex waren onvolidoende netwerken watin alle netwerkeden boven resp. onder de mediaan scoorden, reden warom wij besloten de afwijking var alleen de tweede adviseur bij deze indeling buiten beschouwhing te later.

Vervolgens telden wily, op hovevel componenten een netwerk "homogeen sterk" dar wel "homogeen gexing" of "hetexogeen" werd ingedeeld. Op grond van de combinatie van deze drie variabelen werd tenslotte de definitide indeling van netwerken haar hun mate van homogeniteit bepaald. Om njet alleen heterogene netwerken te identificeren moesten daxbij enkele beslissingen worden genomen ten aanzien van de vraag hoe een combinatie van bijwoorbeeld tweemal de score homogeen sterk, eemal da score heterogeen en weenall de score homogeen gering kon worden benoend (in dit voorbeeld beslotern. wij. zo" metwerk heterogeen te noenem). Tabellen 1 en 2 geven deze keuzer in detall weer. 


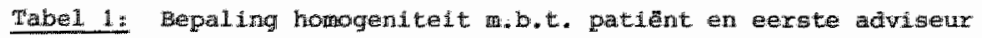

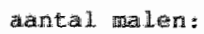

\begin{tabular}{|c|c|c|c|}
\hline homogeen sexk & heterogeen & honwogeen greting & wordt \\
\hline 3 & 1 & 11 & \multirow{4}{*}{$\begin{array}{l}\text { homogeen } \\
\text { sterk }\end{array}$} \\
\hline 3 & 2 & 0 & \\
\hline 4 & $\mathbb{1}$ & 0 & \\
\hline 4 & 0 & 9 & \\
\hline 1 & 4 & 0 & \multirow{10}{*}{ heterogeen } \\
\hline 0 & 4 & 1 & \\
\hline 1 & 3 & 1 & \\
\hline 2 & 3 & 0 & \\
\hline 0 & 3 & 2 & \\
\hline 2 & 2 & 1 & \\
\hline 1 & 2 & 2 & \\
\hline 2 & 1 & 2 & \\
\hline 3 & 0 & 2 & \\
\hline 2 & 0 & 31 & \\
\hline 0 & 1 & 4 & \multirow{4}{*}{$\begin{array}{l}\text { homogeen } \\
\text { gexling }\end{array}$} \\
\hline 1 & 0 & 4 & \\
\hline 0 & 2 & 3 & \\
\hline 1 & 1 & 3 & \\
\hline
\end{tabular}

Tabel 2. Bepaling homogendteit m.b.t. alle metwerkleden aaktal malen:

\begin{tabular}{|c|c|c|c|}
\hline homogeen stexk & heterogeen & homogeen gering & wordt \\
\hline 3 & 1 & 1 & \multirow{4}{*}{$\begin{array}{l}\text { homogeen } \\
\text { sterk }\end{array}$} \\
\hline 3 & 0 & 2 & \\
\hline 4 & 0 & 1 & \\
\hline 4 & 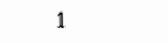 & 0 & \\
\hline 0 & 4 & 11 & \multirow{7}{*}{ heterogeen } \\
\hline 0 & 3 & 2 & \\
\hline 1 & 4 & 0 & \\
\hline 1 & 3 & 1 & \\
\hline 1 & 2 & 2 & \\
\hline 2 & 1 & 2 & \\
\hline 2 & 3 & 0 & \\
\hline 2 & 0 & 3 & \multirow{4}{*}{$\begin{array}{l}\text { Pomogeen } \\
\text { gering }\end{array}$} \\
\hline 1 & $\mathbb{1}$ & 3 & \\
\hline 0 & 2 & 3 & \\
\hline 0 & $i$ & 4 & \\
\hline
\end{tabular}




\section{Achtergronden van prakt sche hulpwetiening en emotionele stewn in. iekannetwerken}

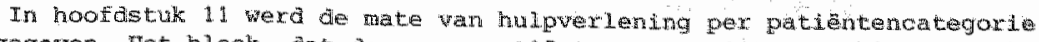

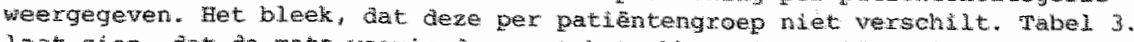
latio zien, dat de mate warin de meest-betrokkene de patient ziek acht, caarmere wel correspondeert.

Tabel 3: Cordeel meest-betrokkene over ziekte patiant naar patjomencategorie

he Hemad gezond (1)
(2)
(3)
(4)

gemiddela

践

eenwegratiantie-analyse $F=8.94$

\begin{tabular}{rrr}
$H$ & 5 & $P$ \\
\hline 4 & 7 & 16 \\
11 & 9 & 5 \\
3 & 5 & 2 \\
7 & 3 & 0 \\
\hline
\end{tabular}

$\begin{array}{ccc}2,52 & 2,26 & 1,33 \\ 25 & 23 & 24\end{array}$

$p<.0004$

Het kan van belang zijn te weten, op welke gronden netwexken warin wel of geen hulp wordt verleend, resp. waarin de patient door de meestbetrokkene gewond of ziek wozt geacht, wan elkaar verschillen. Aangezien wij op deze vraag echter geen sprekend anthoord konder vinden, vermelden wij de resultaten wan onze analyse dienaangaande in deze bijlage. Wij berzen drie kemerken vin de netwerken:

1. De relatie tussen patient en zijh lekeracriseurs deze kan van belang zijn, ondat bljvoorbe la ouders vermodelijith andere functies verwullien voox een chxonisch ziek kind, dan kinderen voor een zileke oudex.

2. De gemidaelde leeftija en het gemiddelde opleidingsniveau van het netwerch.

3. De Jeeftija en het opleidingsnivau van de afzonderlijke netwerk leden.

Tabel 4 gat fin op $(1)$, tabel 5 op de overige achtergronden. In tabel 5 zijn de uitkomsten woor het artsenoordeel gecomtroleero, om eventuele samenhangen met hulp en emotionele steun te zulveren voox de "objectiewe ernst" van de andoening. 


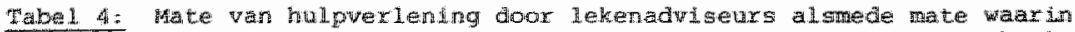

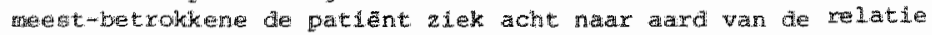

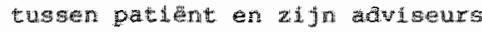

(1) hulpverienting: veel thulp weinig hulp
(2) lekeroordeel ziek gezond geacht

\begin{tabular}{|c|c|c|c|c|}
\hline $\begin{array}{l}\text { partner * } \\
\text { ouder. }\end{array}$ & 1 & 1 & 2 & 2 \\
\hline $\begin{array}{l}\text { partner + } \\
\text { kind }\end{array}$ & 4 & 15 & 7 & 13 \\
\hline $\begin{array}{l}\text { partrex + } \\
\text { overto }\end{array}$ & 4 & 3 & 4 & 6 \\
\hline $\begin{array}{l}\text { alleen } \\
\text { partner }\end{array}$ & - & - & 4 & 24 \\
\hline $\begin{array}{l}\text { ouder + vol- } \\
\text { wassenen }\end{array}$ & 2 & 4 & 1 & 4 \\
\hline $\begin{array}{l}\text { kind + } \\
\text { overig }\end{array}$ & 0 & 3 & 1 & 3 \\
\hline overetg & 0 & 1 & 1 & 0 \\
\hline totáa. & 10 & 27 & 20 & 52 \\
\hline
\end{tabular}

Tabel. 5: Samenhang tussen mate wan hulpverlening en oordeel eexste lekenadviseur over aandoening en leeftijd en opleiding in netwerken (Kendall"s rangcorrelaties)

(1) mate van hulpverlening

nulde- gecontroleerd voor orde artsenoordeel
(2) oordeel ower ziekte door eerste adviseur

\begin{tabular}{lcccc} 
& $\begin{array}{l}\text { nulde- } \\
\text { orde }\end{array}$ & $\begin{array}{l}\text { gecontroleerd voor } \\
\text { artsenoordeel }\end{array}$ & $\begin{array}{l}\text { nulde- } \\
\text { orde }\end{array}$ & $\begin{array}{c}\text { gecontroleerd voor } \\
\text { artsenoordell. }\end{array}$ \\
\cline { 2 - 5 } leeftijd patiënt & -.08 & -.08 &. .24 & .24 \\
leeftijd le adv. & -.14 & -.13 & .14 & .14 \\
leeftijd 2e adv. & -.14 & -.12 & .04 & -.01 \\
gem. leeft. netw. & -.12 & -.12 &. .21 & .21 \\
opleiding patient & -.03 & -.01 & -.13 & -.16 \\
oplelding le adv. & -.10 & -.11 & -.06 & -.04 \\
opleiding 2e adv & .13 & .11 & -.08 & -.04 \\
geiv. opl. netw. & .04 & .04 & -.09 & -.10 \\
N & -11 & 27 & 72 & 50
\end{tabular}

1) voor (2) alleen m. b.t. patiênt en eerste adviseur $\square$ = significant bij

$$
\mathrm{p} \leqslant .05
$$

De tabel Laat geen dudelijke conclusies toe over eventuele achtergronden van hulpveriening en lekenoordeel. De samenhang tussen het laatste en de leeftija van de patiert (en ook de gemidclelde leeftijd van het netwerk) moet vermoedelifk worden toegeschreven an het felt, dat hartinfarct-" patienten gerdadeld wat ouder zi yn dan de andere twee categoriesa en dat zij ook het meest ziek worden geacht. (zie tabel 3.1 
Bijlage 12: Dimensies in de attiudu t.a. v. de eigen arts: bit par. 13.4 .

Formulexing van witspraken

1. Mijn (hulls)arts is nogal ondekex in zijn optraden

2. Mijn huislarts stat erop. at je precles doet wat hij zegt

3. Mijn (huis)arts vertelt me precies hoe ermstig het is

4. Mifn (huis)arts stelt je op je gemak als je met hem pxat

5. Mijn (huls) arts is rogal zakelijk

6. Mijn (hwis)arts schrijet je neuweurig voor wat je noet boen

7. Mijn (huis) arts prat met me over andere dingen dan over min zilekte allien.

8. Mijn (huis)arts legt me uit warom hij iets op een bepalade mamier doet

9. Mijn (huig) arts behandelt me als numer

10. Mijn (huls)arts praat met me over andere dingen dan medushe problemen

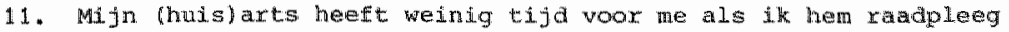

12. Mijn (huis) arts is bereid omar je moeilijkheden te Iuisteren

Varimax rotatie

\begin{tabular}{|c|c|c|c|c|}
\hline Fationen & 1 & 2 & 3 & 4 \\
\hline 1. & 0.11 & -0.07 & 0.13 & 0.80 \\
\hline 2. & 0.01 & 0.05 & 0.77 & 0.23 \\
\hline 3. & 0.03 & 0.64 & 0.39 & -0.12 \\
\hline 4. & 0.73 & 0.29 & 0.18 & -0.18 \\
\hline 5. & -0.39 & 0.00 & -0.07 & 0.70 \\
\hline 6 & 0.12 & 0.17 & 0.79 & -0.12 \\
\hline 7 . & 0.33 & 0.81 & -0.07 & 0.04 \\
\hline 8. & -0.03 & 0.74 & 0.19 & -0.14 \\
\hline 9. & -0.81 & -0.25 & -0.15 & 0.14 \\
\hline 10. & 0.38 & 0.77 & -0.01 & 0.13 \\
\hline 11. & -0.82 & -0.13 & 0.08 & -0.11 \\
\hline \multirow[t]{2}{*}{12} & 0.78 & -0.01 & 0.02 & -0.05 \\
\hline & $\begin{array}{l}\text { commu- } \\
\text { nica- } \\
\text { tief }\end{array}$ & $\begin{array}{l}\text { infor- } \\
\text { matief }\end{array}$ & $\begin{array}{l}\text { instru- } \\
\text { mentee } 1\end{array}$ & a f wexend \\
\hline$r^{2}$ & 33.20 & 14.49 & 10.68 & 9.88 \\
\hline Eigenwarde & 3.98 & 1.72 & 1.27 & 1. .17 \\
\hline
\end{tabular}


Bijalge 13: controlenoouzak en medische consumptite bij paragraaf 13.5

Tabel 1: Controlenoodzadk en medische consumptie van huisartspatienten

\begin{tabular}{|c|c|c|c|c|c|c|c|}
\hline cantitroles & 0 & 1 & 3 & 4.5 & $6-9$ & 10 & Totaal \\
\hline n...t. & 10 & 2 & 1 & 0 & 0 & 0 & 13 \\
\hline Jaratjkm & 1 & 0 & 0 & 0 & 0 & $a$ & 1 \\
\hline $\begin{array}{l}2 \times 2 x \\
3-6 x\end{array}$ & 0 & 3 & 0 & 0 & 0 & 1 & 4 \\
\hline \multirow{3}{*}{$\begin{array}{c}\text { p.je. } \\
1-2 \text { p.mad. }\end{array}$} & 4 & 5 & 0 & 1 & 1 & 0 & 11 \\
\hline & 0 & 1 & 0 & o & 0 & 0 & 1 \\
\hline & 15 & 11 & 1 & 1 & 1 & 1 & 30 \\
\hline
\end{tabular}

Tabed 2: Controlenoodzadk en medische consumptie (huisartsconsulten) van specilalistpatiënten

\begin{tabular}{|c|c|c|c|c|c|c|c|}
\hline controlem & 0 & 1 & 2 & 3 & $4-5$ & $6-9$ & Totaal. \\
\hline n.v.t. & 9 & 0 & 0 & 0 & 0 & 0 & 9 \\
\hline jlaarl. & 0 & 1 & 0 & 0 & 0 & 0 & 1 \\
\hline $\begin{array}{l}2 x p \cdot I x . \\
3-6 \times x\end{array}$ & 5 & 1 & 0 & o & 1 & 0 & 7 \\
\hline 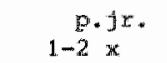 & 10 & 5 & 2 & 2 & 1 & 0 & 20 \\
\hline \multirow[t]{2}{*}{ P.mnd. } & 2 & 0 & 0 & $\mathbb{1}$ & 2 & 1 & 6 \\
\hline & 26 & 7 & 2 & 3 & 4 & 1 & 43 \\
\hline
\end{tabular}

Geen warmening: 1

Tabel 3: Controlenoodzath en medische consumptie (specialistconsulten) van speclalistpatiënten

aantal specialistconsulten

\begin{tabular}{|c|c|c|c|c|c|}
\hline controles & 0 & $1-3$ & $4-7$ & $8-12$ & Tataal \\
\hline$n+v+t$ & 5 & 3 & 0 & 1 & 9 \\
\hline jxi. & 0 & 1 & 0 & 0 & 1 \\
\hline $\begin{array}{l}2 \times p \cdot j x . \\
3-6 x\end{array}$ & 1 & 6 & 0 & 0 & 7 \\
\hline$\underset{1-2}{p \cdot j x}$ & 0 & 3. & 13 & 4 & 20 \\
\hline \multirow[t]{2}{*}{ p.mat. } & 1 & 2 & 1 & 2 & 6 \\
\hline & 7 & 115 & 14 & 7 & 43 \\
\hline
\end{tabular}

Geen waarneming: 1 
官

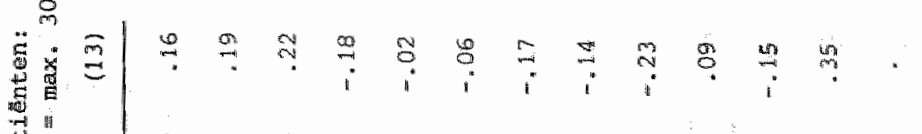

步

戛总

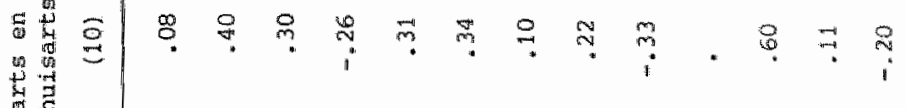

茛出

出

尊

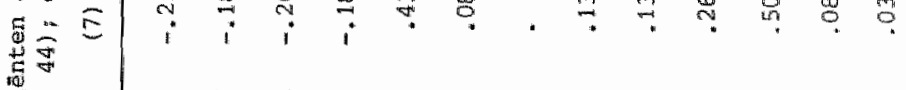

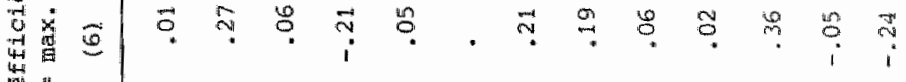

,

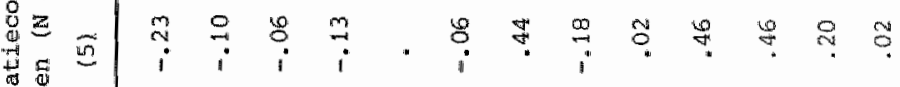

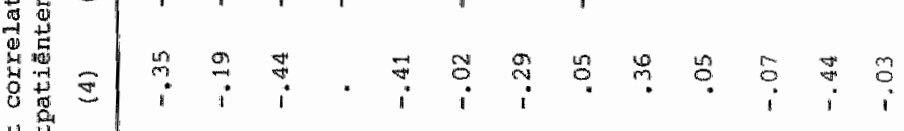

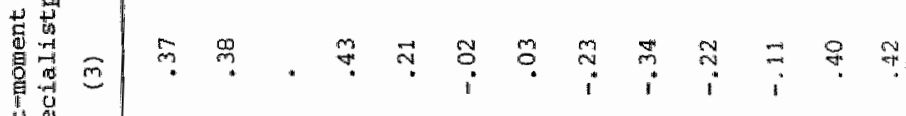

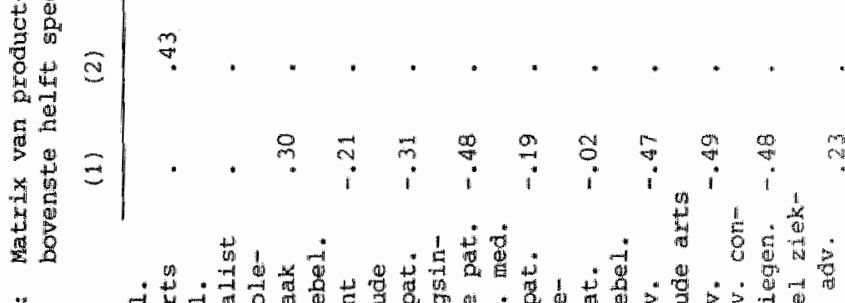

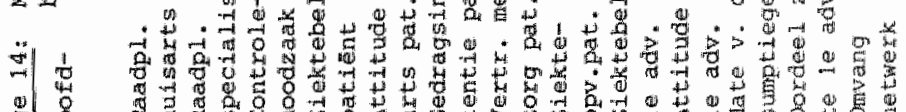

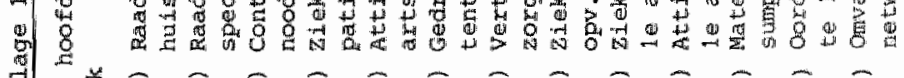

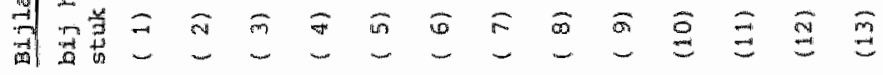


Blyage 15: Variabelen met betrekging tot overige vormen van medische consumpte bif paragraten 14.4 en 14.2 .

1. Veel (wexschillende yormen van) medische consumptie

Per patlentericategorie werd een somscore berekend, warbij woor alle arie de categorifen werd geteld het antal contacten met de huisarts, de "elgen" specialist, een andere specialist (ekcl. oogarts) alsmede eventueel nog niet genoende voorzieningen. Woor hartinfarctpatipnten werd daarbif extra opgeteld het antal bezoeken an een dietiste, aan de trombosedienst en aar een revalidatie-isateliling. Woor diabetici werden de volgende woorzterningen extra lin de beschouwh betrokken: de oogarts, de diêtiste, de revalidatle en het laboxatorlum. Voox psoriasispatianten telden wij bij de hlerworgenoende vooxteninger alleen nog het aantal bezoeken aar een pura-behanfelingscentrum. Tabel 1, bijlage 15 lat de statistische kenwerken van de aldus samengestelde somscores zien.

rabel 1: Statistische kenmerken var "veel (verschiliende vormen pan) medische consumptie"

\begin{tabular}{lrrr} 
& gemidalde & median & bexelk \\
\cline { 2 - 4 } & 10.8 & 9 & $6-23$ \\
P & 12.9 & 12 & $7-24$ \\
& 6.1 & 5 & $4-15$
\end{tabular}

In de tweede platats werd voor alle categorieăn samen een somscore berekend van het aantal bezoeken aan huisarts, "eigen" specialist en overtg specielist (excl, aogartis). Deze scoxe had een bereik van 2-11, het gemidalde is 4.6 , de median 4 .

\section{Het raadplegen vall alternatieve genezers}

De volgende alternatieve genezers wexden in de vragenlijist genoemd: acupuncturist.

homeopaat

osteopaat, chiropraktikex ("bottenkraker")

gebedsgenezer, handopleggex

paranormalle grenezer, magnetiseur, stxijker, helderziende

Iriscopist " "oogkifker")

kruidendoktex 


\section{Bil lage 16: Artsenencuete}

1. Controleert u deze patient regelmatig i.w. w. ..."?

2. Zo meen, wat is hilerworor de reden?

3. Zo ja, welte controlerrequentie hebt u I.w. H. ... voorgesomeven?

4. Is dit waker of minder valk dan u ower het algemeen an

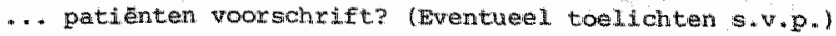

5. Kunt u bij benadering aangeven, hoe ernstig ........ wan ub patient is [bij hartinfarctpatienten: was)?

Bedoeld is die "ernst" in medische zun, vergeleken thet andeke .... patienten. (Eventueel toelichten $s . v \cdot$. D.)

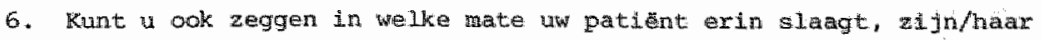
aandoening psychssch te werwerken? (Eventueel toeliohten s.v.p.)

7. Kunt u ook zeggen hoe uw patient i.w.m. ... aoor zijn/hata gezingleden of directe ongeving opgevangen wordt? (Ewentuel toelichten s.v.p.y

8. Eleeft uw patient nog andere andoenlngen warvoor w hem/har regelmatig terug wilt zien? 20 ja, welke?

9. Hebt u nog opmerkingen ower deze patient dis eventueel var belang kunnein zijn voox ons onderzoek?

De vragen $6 \mathrm{t} / \mathrm{m} .8$ worden vaak met "ik zou het nilet weten" af in het gehere niet beantwoord. 


\section{ORHTOLUM VTRE}

De autewr wexd op 11 aptil 1946 in Eindhoven geboren. Van 1953 wot 1966 volgde zij de Jagexe en de midalibare school in Hamburg, West-Duts1and. De schoolopleiding wexd afgerond met het behaler van het Abltur aan het Gymasium van de Waldabrersohule. Zij gtudeende danna westerse socioLoge an de Rijsunlversitelt te Lelden. In 1971 legde zif het doctoxaalexamen af: van 1971 tot 197 was $z+1$ vervolgens werkam bij het centraal Bureau voor de statigtiek met ls voonalmie aandachtspunten: studie naar mokjthkliked voox de ontwikeling van sociale indicatoren en opzet van wer Lefsituatieomderzoek oncer ouderen. Varas 197 werkt zij thans als wetenshappelijk medewerkstex bij het social en cultuxel planbureau in kifswifk. De werkaamheden heblen betrekking op vaagstuken op de terreiJen wan de gezondhe dasorg de matschapplijke dienstrerlening alsmede OP allgemene plannjngsondexwexpen. Dearrast hilda zij zich vanaf 1976 beig met het vervaladigen van onderhavig proefschrift. 
